Joan Serafí Bernat

Celestí Gimeno, editores

Migración e

interculturalidad

De lo global a lo local 


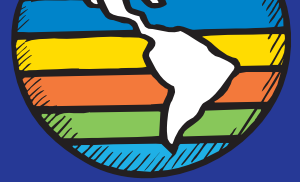

Cooperació i solidaritat. Estudis, 2

JoAn SERAFí BERnat I MarTí (Borriol, 1955) es profesor titular de Historia e Instituciones Económicas y miembro fundador del Instituto de Desarrollo Local de la Universitat Jaume I. Licenciado en Geografía e Historia, sección Historia Contemporánea y doctor en Historia por la Universitat de València. Ha sido director técnico de Profesorado, vicedecano y decano de la Facultat de Ciències Jurídiques i Econòmiques y director del Departament d'Economia de su universidad. Autor, coautor o editor de una decena de obras, de otros tantos capítulos de libros y de una veintena de artículos en revistas especializadas en el campo de la demografía y en otros temas de historia económica y de desarrollo local.

Celestí Gimeno i BROCH (Castelló, 1953) es catedrático de Bachillerato, profesor asociado de Historia e Instituciones Económicas y miembro del Instituto de Desarrollo Local de la Universitat Jaume I. Licenciado en Filosofía y Letras, sección Geografía e Historia por la Universitat de Valencia y doctor en Geografía por la Universitat de les Illes Balears. Ha sido director de la Casa de España en los Países Bajos y director del Instituto Cervantes de los Países Bajos y Bruselas. Ha realizado diversos estudios de demografía histórica y actual y sobre el fenómeno migratorio reciente en el Estado español. 


\author{
JoAN SERAFÍ BERNAT \\ Celestí Gimeno (editores)
}

\title{
Migración e interculturalidad. De lo global a lo local
}




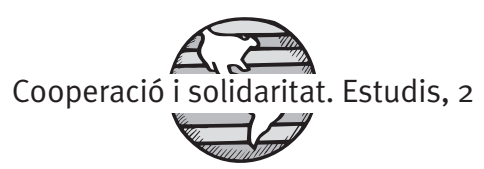

BIBLIOTECA DE LA UNIVERSITAT JAUME I. Dades catalogràfiques

MIGRACIÓN e interculturalidad : de lo global a lo local / [Joan Serafí Bernat, Celestí Gimeno (editores.)]. - Castelló de la Plana : Publicacions de la Universitat Jaume I, 2006

p. ; cm. - (Cooperació i solidaritat. Estudis, 2)

Bibliografia. - Textos en català i castellà.

ISBN: 978-84-8021-574-9

1. Emigració i immigració - Comunitat Valenciana. I. Bernat, Joan Serafí, ed. lit.

II. Gimeno, Celestí, ed. lit. III. Universitat Jaume I. Publicacions, ed. IV. Sèrie.

$325.11 .2(460.31)$

(C) del texto: los autores, 2006

(C) de esta edición: Publicacions de la Universitat Jaume I, 2006

http://www.tienda.uji.es

ISBN: 978-84-8021-574-9

DOI: http://dx.doi.org/10.6035/CISEstudis.2006.2 


\section{Índice}

Presentación ....................................................................... II

Joan Serafí Bernat i Martí, Celestí Gimeno i Broch

I. La migración y la cooperación euromediterránea …............. I7

KHAMLICHI ABOURBAKR

El proceso y las causas de emigración en Marruecos ..................... I9

La cooperación euromediterránea ........................................ 24

Reflexión sobre una cooperación alternativa para el desarrollo ......... 29

2. Sobre la gestión de la multiculturalidad que resulta

de la inmigración: condiciones del proyecto intercultural ............ $3^{\mathrm{I}}$

JAVIER DE LUCAS

Interculturalidad, integración, inmigración: algunos

tópicos y falacias ........................................................... 33

Sobre la caracterización del proyecto intercultural ......................... 39

Las condiciones jurídicas del proyecto intercultural ....................... 4I

Las condiciones políticas del proyecto intercultural ....................... 46

¿Concluyendo? Algunas propuestas para facilitar

el proyecto intercultural .............................................. 49

3. Movimientos de población en la sociedad global ................... 53

Mercedes AlcaÑIZ

Los movimientos de población: breve referencia histórica ............... 56

Tipología de los movimientos de población en la actualidad ............ 65

Conclusiones ............................................................. 74

4. Aproximación teórica a los conceptos de identidad

y estereotipos en una sociedad intercultural ……......................... 77

ENRIC RAMIRO ROCA

Introducción 
Grupos étnicos y arraigo en un lugar: los estereotipos $8 \mathrm{I}$

Los medios de comunicación y la necesidad de analizar

los estereotipos

5. La immigració actual a Espanya. Aspectes demogràfics

ANDREU Domingo i VALLS

Introducció. El boom immigratori del segle XXI 95

L'estranger en el laberint estadístic i legislatiu espanyol .................... 96

Acceleració i diversificació de fluxos i d'efectius .............................. I02

Distribució territorial ................................................................... I08

Factors sociodemogràfics que expliquen l'arribada d'immigrants:

segmentació i complementarietat ........................................... III

Conclusions: complementarietat i exclusió ...................................... II7

6. Algunas consideraciones sobre los procesos migratorios

en España y en tierras valencianas ........................................... I2I

ANDRÉs Piqueras

Migración

Las migraciones como procesos estructurales a lo largo de la historia..

Inmigración en la UE, en España y en el País Valenciano .................... I27

Inmigración en Castellón ................................................................. 133

Limitación de la fuerza de trabajo mundial y utilización de la misma

mediante su extranjerización. El caso del agro valenciano ............. I35

Formas de trabajo irregular de los inmigrantes ................................ I 138

Inversión del flujo migratorio y su reflejo jurídico ............................. I40

\section{Extranjeros en el País Valencià}

(una aproximación imperfecta a la inmigración) ......................... I I45

Rafael Viruela Martínez, Concha Domingo Pérez

Crecimiento acelerado de la inmigración en el País Valencià .............. I48

Diversidad de procedencias: cambios en el paisaje migratorio ............ I5I

Distribución geográfica: concentración y dispersión ......................... $\quad$ I54

Los trabajadores extranjeros en el mercado de trabajo ......................... I60

A modo de conclusión .................................................................. I67

8. Iguals però menys: la colònia romanesa a Castelló .................... I69

Celestí Gimeno i Broch, Joan Serafí Bernat i Martí

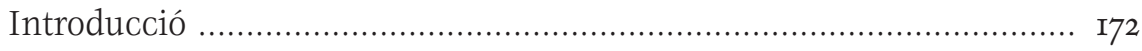


Teories econòmiques sobre els moviments migratoris .................. I77

El model migratori de Castelló dins del context estatal ................... I80

Trets demogràfics dels immigrants a Castelló ................................ I84

Situació econòmica i social de Castelló als anys noranta: factors pull ... 207

Situació econòmica i social de Romania als anys noranta:

factors push 209

9. Recursos en internet sobre la inmigración

en el Estado español

Celestí Gimeno i Broch, Joan Serafí Bernat i Martí

Introducción 221

Objetivos del capítulo 222

Contenidos 222

Información que se ofrece

Valoración de la red como instrumento de estudio del fenómeno y de apoyo a los alóctonos 224

Webs sobre inmigración

I. Centros de investigación y difusión de información y estadísticas 227

2. Instituciones públicas y administraciones 242

3. Asociaciones, fundaciones y ONGS 249

Bibliografía 259

Índice de cuadros, gráficos y figuras 273

Relación de autores 279 


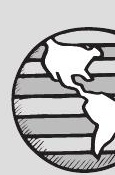

Presentación

JoAn SERAFÍ Bernat I Martí

Celestí Gimeno i BRoch 
El largo proceso histórico de la globalización ha conducido a la situación actual en la que todo habitante de la Tierra se ve afectado por lo que piensa, hace o le acontece a cualquier otro ser humano. La desaparición de las trabas a la movilidad espacial de las mercancías y capitales y todos los factores que lo han hecho posible forzarán, tarde o temprano, la eliminación de la palpable contradicción que supone reforzar las fronteras frente a los desplazamientos de los ciudadanos de un rincón a otro del planeta.

Los estados nacionales, como instituciones, han quedado rebasados por los intereses del mercado y el universalismo de la democracia y de las declaraciones de derechos. Y junto a la disolución del patriotismo decimonónico la necesidad que todos tenemos de anclarnos a nuestros orígenes refuerza el sentimiento de pertenencia a lo local, como seña de identidad y seguridad emocional.

Afirmar que en este contexto mundializado los flujos migratorios repercuten en todos los niveles de nuestra realidad es una obviedad que debería ser innecesaria repetir si los planteamientos xenófobos no alcanzasen el predicamento que lamentablemente tienen y, lo que es peor, todo apunta a que en los próximos años en España pueden afianzarse. La inmensa mayoría nacimos en un sitio, nos formamos y trabajamos en otro y pocos sabemos donde acabarán los restos de nuestros cuerpos. El Diccionario de la Lengua Española de la RAE establece como una de las acepciones del término emigrar la acción de «abandonar la residencia habitual dentro del propio país, en busca de mejores medios de vida».

Sin embargo, desde nuestra óptica de ciudadanos del bienestar, los poderes que generan opinión tienden a limitar la condición de emigrante sólo a quien llega a un estado del que no posee la nacionalidad, es pobre y quiere instalarse de por vida. Pero emigrante es tanto la familia real 
española ${ }^{1}$ como el último cadáver rescatado de una patera ante los acantilados de Lanzarote.

La potencia que han alcanzado los flujos hacia una parte importante del territorio del Estado español en los últimos años, unido a la total ausencia de cualquier tipo de política de inmigración, ha disparado el interés del tema y llegado a preocupar a la opinión pública.

La negativa imagen que de este fenómeno han reiterado algunos medios de comunicación y miembros de la clase política, unido a lo anterior, explica que la inmigración se haya convertido, después del paro y del terrorismo y por encima de la vivienda, según la opinión de nuestros conciudadanos, en uno de los problemas principales que existen actualmente en España. ${ }^{2}$

La comunidad universitaria no ha sido insensible a esta realidad y se ha movilizado, incrementado de manera significativa su dedicación a la cuestión, creando la infraestructura oportuna, constituyendo equipos de investigadores, organizando reuniones científicas, realizando innumerables estudios y participando en actividades de difusión y de sensibilización. En esta línea de acción pretende encuadrarse la publicación que presentamos, fruto del interés institucional y de diferentes iniciativas del profesorado de la UJI $^{3}$ y que a buen seguro tendrá continuidad en un próximo futuro.

1 «Su Majestad el Rey nació el 5 de enero de 1938 en Roma, [...] su formación fundamental se desarrolló en España, a la que llegó por primera vez a los diez años, procedente de Portugal tras su etapa [...] en [...] la ciudad suiza de Friburgo [...] Su Majestad la Reina Doña Sofía nació en Atenas el 2 de noviembre de 1938. Pasó parte de su niñez en Egipto y África del Sur [...] Regresó a su patria en 1946, completó su formación en el internado alemán de Schloss Salem. El 14 de mayo de 1962 contrajo matrimonio en Atenas con el Príncipe Don Juan Carlos de Borbón y Borbón». Extracto de la página oficial de la Casa de Su Majestad el Rey, http://www.casareal.es/casareal/home.html.

${ }^{2}$ Barómetro de mayo. Avance de resultados. Estudio n. ${ }^{\circ}$ 2.607. Centro de Investigaciones Sociológicas. Mayo de 2005. http://www.cis.es/Page.aspx?OriginId= 694 .

${ }^{3}$ Los artículos que componen este libro fueron presentados, en una primera versión, en los siguientes encuentros: Curso de verano de la UJI, «Demografia i societat a principis del segle XXI», dirigido por Mercedes Alcañiz y Joan Serafí Bernat, celebrado del 7 al 9 de julio de 2003; Jornadas de Cooperación Internacional y Solidaridad, «Nuevo orden internacional», celebradas en la usi entre el 4 y el 6 de mayo de 2004; y Curso de verano de la UJI: «La immigració i la multiculturalitat: conceptes, recursos i gestió", dirigido por Mercedes Alcañiz, Enric Ramiro y Joan Serafí Bernat, celebrado del 5 al 10 de julio de 2004. El capítulo 9 ha sido elaborado para esta publicación. 
Deseamos expresar nuestro agradecimiento a: Sonia París Albert, profesora del Departament de Filosofia, Sociologia i Comunicació Audiovisual i Publicitat de la Universitat Jaume I, por haber realizado los contactos y recogido los originales de la mayoría de los autores incluidos en esta obra; a Vicent Martínez Guzmán, director de la colección y a Ana María Fuertes Eugenio, vicerrectora de Cooperació Internacional i Solidaritat, por haber confiado en nosotros la parte que restaba de la tarea editorial; a los autores que generosamente han aportado sus trabajos; y a todas las personas que han participado en los actos de los que se han derivado estos textos. 


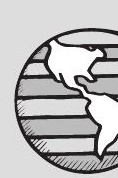

I.

La migración y la cooperación euromediterránea

KHAMLICHI ABOURBAKR 
Intentaré enfocar el tema basándome en el análisis del proceso migratorio en Marruecos desde la independencia e insistiendo sobre las principales causas internas y externas de la emigración, haciendo constar la importancia y el interés de que cualquier perspectiva de limitación del fenómeno debería ser orientada al tratamiento de estas causas y no a través de soluciones represivas y de seguridad.

En segundo lugar intentaré avanzar una lectura personal de la cooperación euromediterránea actual y presentar una alternativa de cooperación a través de una experiencia modesta, la de Las Dos Orillas, iniciada en 1997 entre el movimiento asociativo del Norte de Marruecos y las ongs de Andalucía.

\section{EL PROCESO Y LAS CAUSAS DE EMIGRACIÓN EN MARRUECOS}

Como se sabe, la migración es un fenómeno complejo y difícil de describir en cuanto a las implicaciones y consecuencias que tiene sobre la sociedad. En este artículo intentaremos presentar algunos rasgos históricos y las principales causas del fenómeno.

El hecho colonial transformó a Marruecos en una prolongación del mercado francés; de esta manera el flujo migratorio estaba controlado por el Ministerio Francés de Guerra con triple objetivo: económico, militar (reclutamiento de los marroquíes en el ejercito francés, sobre todo en tiempo de las dos guerras mundiales) y político (orientaba la emigración a las regiones con más resistencia al colonialismo, en particular la región de Sous, cuya conquista no terminó hasta el año 1934). De hecho, la evolución del movimiento migratorio durante el protectorado fue sujeta a las necesidades económicas y militares, como lo demuestran los datos siguientes: 
- Entre 1914 y 1918: Se pasó de 14.000 a 28.000 emigrantes como efecto de la Primera Guerra Mundial.

- En 1919: Bajó a 19.000 emigrantes, como consecuencia de la repatriación, una vez finalizada la guerra.

- En 1934: De 21.000 descendió a 10.000 emigrantes debido a la crisis económica.

- Entre 1945 y 1955: Se redujo de 40.000 emigrantes (de los cuales 12.000 eran militares) a 10.000 después de la Segunda Guerra Mundial.

- Entre 1956 y 1960: El movimiento migratorio marroquí a Francia conoció un cierto estancamiento, con unos 29.700 emigrantes.

El fenómeno de emigración evolucionó en las décadas de los años 60 y 70 de una forma remarcable, y así en las siguientes décadas se transformó en un componente estructural de las relaciones Maghreb-Unión Europea, a razón de sus incidencias a nivel económico, social, político y cultural. Así, podemos diferenciar varias etapas según la forma y el volumen:

- La primera etapa: Desde 1960 (unos 30.000) hasta los años 70 (553.000 en 1977) adquirió un auge sin precedentes. Amplió sus destinos a diversos países europeos (Bélgica: 60.000; Holanda: 45.000; Alemania Federal: 25.000; España: 50.000; Gibraltar: 3.000), aunque siguió orientada principalmente hacia Francia (en 1977 absorbía al 70\%). En este período fue especialmente masculina e individual.

- La segunda etapa: Desde la crisis económica y la preconización del nuevo orden mundial, empezó su política de limitación del fenómeno migratorio. Esta política tuvo como consecuencia inmediata la manifestación de nuevas formas de emigración. La preagrupación familiar conoció un gran auge, dando lugar a la emigración de la mujer y la juventud.

- La tercera etapa: Frente a las medidas restrictivas que empezaron a aplicar los países de la UE, sobre todo después de la aplicación del tratado de Singer en 1985 (1.000.000) y la instauración del visado, se agravó el fenómeno de la emigración clandestina con todas sus desgracias humanas.

- La cuarta etapa: En los últimos años de la década de los 90 apareció un nuevo y escandaloso fenómeno, que es la emigración de los menores, con las formas y métodos mas aventurados y peligrosos, dando lugar a un número muy elevado de víctimas entre estos niños, sin hablar 
de todas las consecuencias psicológicas y sociales que supone para estos niños. Este nuevo fenómeno está muy ligado al deterioro y la degradación de la situación material y moral, así como a la explotación inhumana de estos niños y a la ausencia de perspectivas para el futuro.

Es verdad que esta emigración masiva, cada vez en condiciones más inhumanas y desastrosas, con un grave número de víctimas, es el resultado de factores externos y factores internos.

\section{Factores internos}

En primer lugar trataremos de analizar las causas del fenómeno migratorio correspondiente al proceso socioeconómico y político del país de origen y en nuestro caso de Marruecos, que podemos resumir en los siguientes factores principales:

1. La emigración externa representa una componente del éxodo rural, resultado de la mutación de la estructura agraria, donde el 66\% de las tierras de los colonos (1 millón de hectáreas) pasó a las manos de los llamados nuevos colonos (burguesía makhzani y comercial), y paralelamente a los grandes terratenientes existentes en el sector agrícola tradicional, que reforzaron su patrimonio acaparando las tierras de los pequeños propietarios obligados a la emigración. Según Paul Pascon, la población rural sin tierra representaba el 76\% de la población rural en 1984, mientras que una minoría insignificante y ausente (urbana) concentra las tierras más fértiles, además del aprovechamiento de las subvenciones del Estado y de seguir estando exentas de impuestos. Lo más destacado es que el fenómeno de emigración no se afirme solamente en las regiones rurales pobres y marginadas (el Marruecos inútil), sino que de una forma exultante aparece en las regiones de riego consideradas las más ricas: caso de Beni Melal; Ksar Elkebir...

2. Un sistema de enseñanza inadecuado, factor de proletarización, marginalización y desesperación. La no escolarización y el fracaso del sistema de enseñanza (objetivo deseado por el régimen con el fin de asegurar la continuidad del makhzen) pueden considerarse como causas directas del fenómeno de la migración en Marruecos. Es obvio que la lucha contra el 
fenómeno migratorio está condicionada por la necesidad urgente de una nueva política de enseñanza en Marruecos, condición sin la cual no es posible una opción alternativa de desarrollo.

3. La monopolización de la economía del país por la mafia makhzani, reforzada por todos los métodos ilegales imaginables y no imaginables: corrupción, utilización del poder, drogas, contrabando, etc., además del fracaso del sector privado parasitario, dependiente e incapaz de poder crear nuevas actividades e iniciativas. De hecho, históricamente, este sector ha evolucionado de forma parasitaria sobre los sectores económicos existentes.

- La recuperación de las tierras de los colonos durante las décadas 50 y 60 .

- Marroquinización de la economía en la década de los años 70, después del fracaso de los dos golpes de Estado de 1971 y 1972.

- Privatización en los años 80 y 90, como componente de los programas de ajuste estructural impuestos por las instancias financieras internacionales (BM y FMI).

Por lo tanto, no se puede imaginar un desarrollo económico concreto en Marruecos sin una transformación seria del sector privado y una nueva política económica alternativa con cierta autonomía.

4. Degradación continua de la situación social, que se caracteriza por unas diferencias sociales inimaginables, donde un número limitado de familias detentan una gran parte de la riqueza del país, en un momento en el que más del 40\% de la población vive por debajo del límite de la pobreza, y un $40 \%$ de la población activa sufre las desgracias del paro. Lo que implica la necesidad de una redistribución de la riqueza del país y el fomento de una política social que responda a las necesidades de la sociedad.

5. Otro de los factores muy importantes que empuja a la juventud a buscar una nueva vida más allá de las fronteras es la falta de democracia y de los derechos humanos. De hecho, la feroz represión del régimen limita las posibilidades de expresión, de organización y de lucha de la juventud en su propio país por el derecho al trabajo y a una vida digna, lo que les obliga a buscar alternativas y entre ellas la emigración clandestina con todas sus consecuencias dramáticas e inhumanas. La falta de democracia y del respeto de los derechos humanos implica la marginación y la no participación 
de los ciudadanos en las decisiones y las políticas de su país, lo que engendra la pasividad, el desinterés y la pérdida de sentimientos como personas hacia su propio país. Es obvio que la instauración de una verdadera democracia y el respeto de los derechos humanos, permitiría a una buena parte de la juventud luchar por un cambio en su propio país y limitaría en gran medida el fenómeno de migración.

6. El migrante como mito y factor de migración. El elevado poder de compra del migrante de regreso a su país constituye un factor suplementario e importante que hace revalorizar a los ojos de todo el mundo, y en particular de los eventuales candidatos, la credibilidad de la condición del emigrante y la utilidad de la emigración. Esto incide en diferentes grados: en cuanto a la imaginación, la conciencia colectiva, familia, localidad, región y hasta nacional, y constituye un potente factor de la dinamización del movimiento migratorio. Así, se ha desarrollado todo un universo de mitos sobre el emigrante que tiene el poder de procurar el dinero en la tierra de la facilidad (Europa), y la gente cree que éste se ha adquirido sin sufrimientos ni sudor. Los emigrantes tienden a proteger esa imagen guardándo, bien por pudor o vanidad, silencio sobre las terribles realidades de la vida cotidiana, los sufrimientos, y el precio exorbitante que le ha costado obtener esos miserables euros, que sus familiares y vecinos consideran como riqueza. Los emigrantes contribuyen al desarrollo y al mantenimiento de este universo de mitos, que constituyen uno de los factores potentes incitantes del fenómeno de la migración. Es importante proceder a la educación y sensibilización de los emigrantes con el fin de superar la dualidad de su personalidad entre la realidad concreta y la imagen que intenta fomentar en su país de origen, y dar una información más real y objetiva de la vida del emigrante, con el fin de cuestionar el modelo triunfalista.

\section{Factores externos}

En segundo lugar, es evidente que los factores externos constituyen las principales causas de la desigualdad norte-sur y del creciente abismo, como proceso iniciado por la colonización a través de la explotación directa de los recursos naturales de los países del Sur, continuado después por las nuevas formas de dependencia y dominación de las economías de estos países, y actualmente mediante la globalización que imponen las leyes 
del mercado único, dando lugar al aumento de los desequilibrios territoriales, y a la desestructuración de las formas de vida tradicionales que obliga a la emigración.

Otro factor externo, en general no mencionado e ignorado, es la propagación triunfalista en los mensajes políticos e ideológicos del modelo neoliberal como una única perspectiva de la historia y de la humanidad. Creo que este mensaje totalitario constituye un grave error y uno de los elementos-factores importantes de la estimulación del fenómeno migratorio hacia la búsqueda del paraíso. Es obvio que este modelo, a expensas de sus facetas positivas o negativas, está fuera del alcance de la realidad socioeconómica y política de la mayoría de los países del Sur, por lo cual es impensable construir un proyecto de desarrollo posible en ausencia de otros modelos alternativos adaptados a nuestra realidad. Rechazar el modelo neoliberal no impide que podamos ser más o menos felices que los demás, basta asegurar una vida digna y cierta autonomía.

Como conclusión, la lucha para limitar el fenómeno migratorio debe basarse en alternativas de desarrollo globales, que tomen en consideración los diferentes factores enumerados. En este marco se puede reflexionar sobre la naturaleza y las formas de cooperación deseadas.

\section{LA COOPERACIÓN EUROMEDITERRÁNEA}

El Mediterráneo se ha convertido hoy en la zona de enfrentamiento más peligrosa del planeta y con razón es la región donde se concentra la principal riqueza, el petróleo, y por tanto, donde el juego de las grandes potencias se desarrolla con tanto cinismo y dureza. Con conflictos abiertos, sangrientos: Oriente Medio, Irak, Turquía, Chipre, la ex-Yugoslavia; y otros conflictos potenciales, portadores de violencia y destrucción: el reparto desigual de la riqueza, el repliegue cultural, el desplazamiento no controlado de los flujos migratorios; conflictos potenciales que se desarrollan y que pueden acarrear grandes fatalidades a la región mediterránea.

De hecho, una veintena de Estados bordean el Mediterráneo y totalizan cerca de 400 millones de personas. Cuatro de ellos pertenecen a la UE: sus 165 millones de ciudadanos disponen de una renta media cercana a los 19.000 dólares anuales. Los 235 millones de habitantes de los otros Estados tienen, de media, una renta anual de 1.900 dólares, es decir diez veces menos. En una generación, hacia el año 2025, la población de los cuatro 
Estados europeos apenas aumentará hasta 170 millones, mientras que la de los otros habrá crecido en un 70\% y se acercará a los 400 millones. La diferencia entre los niveles de vida será mucho mayor.

En este contexto, debemos reflexionar sobre qué tipo de cooperación debemos construir para hacer frente a las grandes amenazas de la región, ya que la cooperación solidaria es la esencia de la humanidad y el elemento más importante para un verdadero desarrollo equilibrado de nuestra área mediterránea, como reto de un mundo alternativo posible.

Pero antes de presentar algunas reflexiones sobre los objetivos y criterios de una cooperación alternativa, es importante avanzar nuestra lectura crítica y rápida de la naturaleza y las formas de la cooperación actual, a través de los cuatro actores de la cooperación al desarrollo.

\section{La UE y la cooperación para el desarrollo}

Nuestra primera reflexión consiste en preguntarnos sobre si existe una verdadera voluntad de la uE en favor del desarrollo de los países del Sur. Históricamente, la relación entre los países europeos y los del Sur ha sido de tipo colonial, con la finalidad de convertirlos en una extensión de sus mercados nacionales, y como fuente de materias primas a bajo precio y de mano de obra barata, de manera que sean dependientes económica, social y políticamente.

$\mathrm{Su}$ independencia en los años 50 y 60 no ha supuesto una verdadera liberación política y económica, ni siquiera a nivel cultural, ya que en el caso de Marruecos el idioma francés sigue predominando a nivel de la administración. De hecho, el destino de estos países sigue estando sujeto a la política y los intereses de la UE. La economía fue orientada en función de los intereses y las necesidades de la metrópolis, y esto se refleja en las estructuras de producción orientadas a la exportación para satisfacer las necesidades del mercado de la UE, así como en la hegemonía del capital extranjero. En ningún momento la economía ha podido ser autónoma, soberana y en función de las necesidades y las prioridades de sus propios pueblos.

Más aún, en los años 80 y bajo la presión de la deuda externa, las instancias financieras internacionales (FMI, BM) impusieron los programas de ajuste estructural para la readaptación de las economías de estos países a la política de globalización, en detrimento de las necesidades elementales de los pueblos de estos países, aumentando de esta forma la marginación, 
la exclusión y el paro, y limitando el papel del Estado a la función de seguridad y al mantenimiento del estatus quo en favor de los intereses de las multinacionales y de una minoría parasitaria de estos países.

Así pues, podemos avanzar que el objetivo de la política de la cooperación actual de la ue consiste en la continuidad y la extensión de su mercado, en ausencia de elementos concretos que nos puedan demostrar que esté relacionada con el objetivo de un verdadero desarrollo de estos países. De hecho, esta cooperación se desarrolla en una coyuntura condicionada por la globalización, que engendra cada día más pobreza, enfermedades, marginación, paro, guerras, y el expolio de los recursos humanos y naturales de estos países. Sin hablar de que la cifra global de la ayuda a la cooperación está relativamente por debajo de las necesidades de estos países y no representa ni siquiera una pequeña parte de los servicios de la deuda externa, sin mencionar los flujos del capital extranjero y del intercambio desigual entre las dos partes.

Una verdadera política de cooperación entre las dos orillas del Mediterráneo, con el objetivo de engendrar un verdadero desarrollo de los países del sur, implicaría nuevas relaciones más equilibradas, la anulación de la deuda externa, un intercambio más justo y cierta autonomía de las economías de estos países basada en las necesidades internas y complementarias de la región.

\section{La cooperación y los gobiernos de los países del Sur}

En el caso de Marruecos no hace falta mucha imaginación para resaltar el papel nefasto de los gobiernos en la cooperación para el desarrollo. Las condiciones económicas, sociales y las características de las instituciones públicas reflejan de una forma contundente este papel.

La naturaleza del Estado Makhzani, caracterizado por la omnipotencia, la corrupción, el abuso del poder y el control de las relaciones políticas, sociales, económicas, y culturales está asfixiando toda tentativa o iniciativa de los restantes actores políticos y sociales. En ausencia del conocimiento y la conciencia de esta realidad, es muy difícil poder orientar la cooperación en favor de un desarrollo verdadero. De hecho, el Makhzan tiene una gran capacidad de desviación de los fondos de la cooperación, a través del monopolio de los diferentes espacios políticos, sociales, económicos y culturales, convirtiéndose en el obstáculo principal de cualquier cooperación para el desarrollo. 


\section{La cooperación y las ONGS}

En primer lugar cabe preguntarse: ¿qué hacen estas ongs en sus países de origen, cuyas políticas generan la desigualdad entre el Norte y el Sur? ¿Simplemente deben conformarse con el papel de atenuar las consecuencias de estas políticas, sin necesidad de comprometerse en la lucha contra las raíces de la pobreza, la marginación, y la exclusión, es decir la lucha contra los acuerdos globales del comercio injusto, los programas de ajuste estructural impulsados por el FMI y BM, el comercio de armas, la privatización de los servicios públicos, las modificaciones legislativas que arrebatan los derechos históricos a los trabajadores, los flujos financieros incontrolados, la deuda externa...? ¿La tendencia a la profesionalización de las oNGs es realmente una garantía de efectividad o más bien una necesidad para acoplarse a las reglas de las instituciones financieras? ¿Cuál es la prioridad de las onGs, su continuidad y sus propios intereses o las necesidades de las realidades sociales donde actúan? También hay que preguntarse si los proyectos sirven más bien para resolver el problema del empleo de la UE o para el desarrollo de estos países.

Pero dentro del marco limitado de las ongs cabe manifestar las observaciones siguientes:

- Su tendencia a una intervención más ligada a las instituciones oficiales o asociaciones paraestatales.

- El reconocimiento de la realidad y la no participación de la población en la selección de los proyectos.

- La tendencia a la realización de los grandes proyectos y la ausencia de la posibilidad de cierta continuidad de éstos.

- Una acción muy dispersa y sectaria, en ausencia de una concepción global del desarrollo deseado en el país o región en cuestión.

- Una relación desequilibrada entre las ongs potenciadas con los medios financieros y las asociaciones necesitadas resignadas a aceptar las condiciones y las orientaciones impuestas.

En conclusión, la acción de las ongs es puntual y de corto plazo, sin ninguna estrategia para asegurar una acción global y continua en el tiempo, lo que supone en concreto la práctica de un cierto desarrollo chapucero, quizás igual o peor de lo que han venido practicando las instituciones públicas. 


\section{La cooperación y el movimiento asociativo}

En los años 90 el movimiento asociativo en Marruecos conoció una evolución espectacular, con la creación de miles de asociaciones de todo ámbito: desarrollo, ecología, barrios, mujer, discapacitados, amazigh, parados, derechos humanos, culturales. Se estima la existencia de más de 30.000 asociaciones.

Actualmente, el mundo asociativo se puede considerar como un actor importante, imposible de ignorar su papel en la escena sociopolítica del país. De hecho, ha demostrado su capacidad de iniciativa y de acción, permitiendo una espectacular participación de la ciudadanía en el desarrollo y fomentando así la democracia participativa.

Sin embargo, la evolución de este fenómeno sigue siendo muy limitada en razón de varios factores, a saber:

- El hecho de que este espacio, dado su importancia, es objeto de su utilización para fines contrarios. En concreto, el makhzan trata de utilizarlo, ya sea creando asociaciones dependientes (asociaciones de montes y ríos) o intentando canalizar las asociaciones existentes.

- La división y la falta de coordinación de las asociaciones es lo que limita su posibilidad de intervención a niveles superiores.

- La mayoría de estas asociaciones no dispone de una concepción clara de su papel y del movimiento asociativo en el desarrollo, lo que limita sus acciones en ausencia de una estrategia.

- La ausencia de formación de la mayoría de los responsables y cuadros de estas asociaciones en el dominio de la gestión y de la democracia participativa, limita y resta eficacia al esfuerzo importante realizado.

- La mayoría de estas asociaciones no dispone de los medios mínimos (local, medios de comunicación y desplazamiento) que les permitan unas condiciones de trabajo adecuadas.

- La mayoría de las asociaciones percibe su espacio de acción de forma muy superficial, en ausencia de diagnósticos de la realidad sobre la que actúan, dado los escasos medios para realizar estudios y su formación limitada.

- Así, la mayoría de las asociaciones trabaja sin planificación ni programación de sus acciones, según lo que encuentran y lo que les ofrecen. 


\section{REFLEXIÓN SOBRE UNA COOPERACIÓN ALTERNATIVA PARA EL DESARROLLO}

La concepción de una cooperación euro-mediterránea alternativa debe basarse en el fomento de la solidaridad entre los pueblos, ya que hablar de otro mundo posible significa trabajar por un mundo más solidario. Es decir, el fomento de la solidaridad entre los diferentes componentes de la sociedad y entre los pueblos constituye la resistencia y el elemento más importante para un desarrollo alternativo más duradero y más justo.

En esta perspectiva podemos avanzar algunos criterios y consideraciones generales como base de un modelo de cooperación alternativo para el desarrollo:

- En primer lugar, rechazar la cooperación como caridad, como ayuda al pobre, como forma de frenar movimientos de lucha y transformación mediante ayudas que frenen los conflictos sociales y encubran la desigualdad estructural entre el Norte y el Sur. Al contrario, la cooperación debe darse en el terreno de la lucha por una transformación social, contra las desigualdades entre el Norte y el Sur, contra la explotación del Sur por el Norte y por unas relaciones más solidarias e igualitarias entre los pueblos.

- Es importante no caer en el error de considerar el modelo de desarro1lo europeo como el único viable para todos los pueblos. Es necesario que cada país construya su propio modelo, fruto de su historia, sus posibilidades, su cultura y del potencial creativo de su pueblo.

- El título de la cooperación puede contribuir a la idea de que las soluciones a la problemática del desarrollo podrían venir del exterior. El verdadero desarrollo debe ser obra de la sociedad en cuestión y de la política llevada a cabo. Y en este cuadro es imprescindible el papel de la cooperación y la solidaridad entre los pueblos.

- No se puede hablar de desarrollo en ausencia de los ciudadanos, de crecer y decidir por sí mismos sobre las opciones de sus vidas. Por lo tanto, la libertad de los ciudadanos, su libre participación, sus iniciativas creativas e innovadoras, sean a nivel individual o colectivo, constituyen la condición imprescindible para un desarrollo alternativo posible. Desgraciadamente, la situación en Marruecos se caracteriza por la ausencia de democracia, dada la omnipresencia del Makhzan que intenta controlar todos los mecanismos políticos, económicos, sociales y 
culturales. Y aquí hay un espacio prioritario de solidaridad para la lucha en favor de los derechos humanos y la libertad de los pueblos.

- La cooperación debe basarse en la igualdad entre las dos partes, como elemento de una misma lucha, con objetivos comunes y compartidos, al margen de la nacionalidad y mucho menos de la idea del rico y del pobre. Y en la necesidad de fomentar una cooperación entre los pueblos basada en el respeto mutuo, creando redes de intercambio de experiencias y de comunicación, capaces de generar contactos abiertos, diálogos directos entre las diferentes sociedades, con la finalidad de un conocimiento mutuo más profundo, y como base y elemento clave de un modelo de cooperación para el desarrollo. 


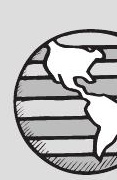

2.

Sobre la gestión de la multiculturalidad que resulta de la inmigración:

condiciones del proyecto intercultural

JAVIER DE LUCAS 
INTERCULTURALIDAD, INTEGRACIÓN, INMIGRACIÓN: ALGUNOS TÓPICOS Y FALACIAS

Las páginas que siguen tratan de señalar o, mejor, recordar, algunas imprecisiones, si no falacias, que han alcanzado el grado de tópicos a propósito de dos argumentos de la mayor importancia: el primero, la «nueva» condición de multiculturalidad de nuestras sociedades, que las más de las veces se relaciona unívocamente con los nuevos flujos migratorios. El segundo, el proyecto de interculturalidad que suele ser invocado como modelo de gestión de esas nuevas realidades. Muy concretamente, me interesa la crítica de la bienintencionada apuesta por una soi-dissant interculturalidad presentada como bálsamo milagroso que resolvería todos los problemas surgidos de la presencia de esos agentes de la diversidad cultural que serían los inmigrantes, otros individuos y grupos que se afirman culturalmente diferentes.

Esta falacia se apoya las más de las veces en otra falacia previa, la que pretende que la diversidad cultural es siempre producto de factores alógenos, como si no hubiera pluralidad cultural endógena. Y eso es lo que convendría recordar ante todo: nuestras sociedades no se han convertido ahora en multiculturales como consecuencia de la llegada y la presencia de los inmigrantes (difícil, por las condiciones de inestabilidad que se imponen a los recién llegados y por lo insólito de esa situación para los que residen de antiguo, que no están preparados para este fenómeno). La inmensa mayoría de nuestras sociedades, en los países de la UE, ya eran multiculturales, con una multiculturalidad interna (nacional, lingüística, religiosa, etnocultural) diversa pero que tiene un elemento común, un modelo de gestión que no es precisamente el de la interculturalidad, sino que se caracteriza por la falta de voluntad de reconocimiento de la diversidad cultural, que ha llevado históricamente a la negación (por aniquilamiento, por segregación, por subordinación, etc.) de tal realidad plural. 
Con la llegada de los inmigrantes podríamos decir que, simplemente, llueve sobre mojado.

Por esa razón, me interesa aún más recordar que no hay recetas milagrosas y que lo que llamamos interculturalidad, las más de las veces, es mera retórica. Porque para hablar de interculturalidad, en serio, deben darse algunas condiciones que trataré de recordar y que, a mi juicio, están aún lejanas, sobre todo en nuestro país, cuando lo que concita buena parte de nuestros esfuerzos, a propósito de cómo gestionar la diversidad cultural procedente de la inmigración, es el objetivo de asentar la tesis del «inintegrable cultural».

La importancia de la discusión sobre esas condiciones reside sobre todo en que pone de relieve que el debate sobre la multiculturalidad y las recetas para gestionarla (la interculturalidad) en no pocas ocasiones es sólo una coartada para ocultar la verdadera dimensión de nuestros problemas, que es muy bien conocida: la igualdad social, económica, cultural y política, es decir, igualdad en el acceso al poder y a la riqueza, un acceso en el que se imponen condiciones discriminatorias y de subordinación, precisamente justificadas desde o por la diferencia cultural. Junto a ello, intentaré poner de relieve algunas imprecisiones a propósito de los instrumentos jurídicos de la política de inmigración, en particular sobre la integración.

La primera de las condiciones a las que me refiero en relación con la interculturalidad es precisamente ponernos de acuerdo en el sentido que atribuimos a ese término. Y no es nada fácil. No se trata, obviamente, de un status, de una situación de hecho, ni tampoco de un resultado que pueda producirse por mera buena fe, a base de voluntarismo, ingenuidad y arcadismo. La interculturalidad es una propuesta normativa, un modo de gestionar la diversidad cultural, que no puede confundirse con ésta, ni con la multiculturalidad, pero tampoco equivale como se dice tan alegremente, al mestizaje.

La apuesta en que consiste la interculturalidad, a mi juicio, debe distinguirse con cuidado de la asimilación impuesta, del paternalismo cuando no imperialismo cultural que tantas veces le subyace. Así sucede cuando se equipara interculturalidad e integración, sin precisar el uso de este segundo concepto. En efecto, reza el tópico bienintencionado que toda gestión de la diversidad cultural debe orientarse hacia la integración social y no a la mera asimilación (ni, desde luego, a la segregación). Pero la integración social es un concepto complejo que no debiera identificarse con integración cultural y que no puede describirse en los términos unidireccionales 
que sugieren que el anfitrión ingiere al de fuera permaneciendo inalterado. ${ }^{1}$ Estamos hablando de procesos de interacción, de adaptación mutua, que exigen cambios de ambas partes y que harán crecer la pluralidad. La imagen de una sociedad de acogida que «integra» a los de fuera permaneciendo igual a sí misma - como el cristal atravesado por la luz, como en la concepción inmaculada - es, por encima de un mito, un error, salvo que se imponga el modelo de asimilación impuesta, de aculturación brutal, basado en la negación de la condición de persona de todo otro, en la negación de reconocimiento, de valor a cuanto es y cree el otro. Las políticas de integración e interculturalidad no pueden tener como destinatario exclusivo (ni siquiera primordial) al otro, sino que han de contemplar a la población indígena.

La verdad es que no es difícil deconstruir el mito de la «cultura anfitriona» como paradigma y aún más, como molde en el que debe desaparecer toda cultura alógena que pretenda su integración. Se trata de un supuesto contrafáctico, pues resulta de todo punto imposible un proceso social de interacción y que a la vez se traduzca en un solo sentido, esto es, que la cultura anfitriona incorpore a las alógenas sin quedar transformada a su vez. Más que una tesis, esta es una propuesta ideológica, la que acompaña por ejemplo a la concepción de la cultura propia de la KulturNation, que desemboca, como ha mostrado Stolcke, en fundamentalismo cultural, en esencialismo. Por el contrario, resulta evidente la necesidad de someter a crítica tales concepciones esencialistas/naturalistas de la identidad y mostrar cómo la construcción de la identidad, como ya advirtieran Barth o Glazer y recuerda Taylor, es precisamente un proceso, que se lleva a cabo en contraste dialógico con los otros, una «operación basada en el juego de semejanzas y diferencias». Las identidades culturales son precisamente esas relaciones, esas estrategias de adaptación para la interacción social. Como ya hemos visto, la conclusión es que la mayor parte de los conflictos que se presentan como identitarios pueden resolverse en conflictos de intereses acerca de la distribución de la riqueza y de la participación en el poder y de las condiciones para esa participación y distribución. En otros términos, pueden traducirse en negociación razonable de las reglas de juego de la convivencia plural, en lugar de permanecer anclados en la estrategia funcional al grupo dominante, una estrategia que, como ha descrito

${ }^{1}$ Entre nosotros, los trabajos de Delgado (1999), Giménez (1996), Stolcke (1998), o Álvarez Dorronsoro (1998) son claros exponentes de esas tesis. 
Bourdieu, se basa en el monopolio de la tarea de segmentación, de taxonomía social, como instrumento privilegiado de las estrategias simbólicas de legitimación-naturalización del orden, herramientas clave para perpetuar el statu quo (la «estrategia de sociodiceas» en expresión del sociólogo y politólogo francés).

Pero tampoco se persigue en serio la integración si olvidamos la situación de asimetría en la relación de acogida que se da concretamente en los procesos de inmigración a los países de la UE. Nosotros estamos en la mejor posición, en la de dominio, y por ello tenemos la carga de enseñar las reglas de juego (y parte importante de ello son los derechos y los deberes de quienes vienen de fuera) y de comenzar nosotros por reconocer nuestros deberes, antes que exigirlos por la vía de la amenaza, de la imposición, a quien es estigmatizado de entrada como sospechoso de ponerlos en peligro aunque ni siquiera le hayamos dado la oportunidad no ya de pronunciarse sobre ellos, sino de conocerlos. Quienes estamos en la posición de poder somos los obligados a empezar y esta es una consecuencia que no se destaca en planteamientos como los de Sartori, Todd o incluso Agnes Heller. La sociedad de acogida debe dar el primer paso, que no es el de la tolerancia, la condescendencia paternalista o los buenos modales propios de la gente civilizada, sino el de la garantía de derechos y, por tanto, la iniciativa a la hora de enseñarlos - como también, desde luego, de enseñar los deberes. Esto tiene particular importancia desde el punto de vista de la relación entre integración y reconocimiento de derechos (que no son una consecuencia, sino una condición para la integración) y en particular acerca de la atribución de derechos políticos.

Sólo desde una perspectiva rabiosamente etnicista, que sostenga la presunción de que la sociedad de acogida es siempre superior, ${ }^{2}$ a la par que homogénea en esa identidad superior - al menos culturalmente, se dicey que esa superioridad y homogeneidad no precisan ser discutidas, sólo desde esos puntos de partida, insisto, puede defenderse la viabilidad de semejante modelo, cuya conclusión a propósito de la inmigración es que hay que acoger sólo a quienes cumplan dos condiciones: ser útiles en nues-

${ }^{2}$ O que debiera serlo, como en el hermoso texto de Alberto Savinio, el hermano de G. di Chirico, Ciudad, escucho tus latidos. En el horizonte normativo, en el plano del deber ser, es donde juega sus mejores bazas otra perspectiva, menos burda, pero que lleva a menudo a idénticas conclusiones. Me refiero a la visión universalista abstracta, a veces disfrazada de cosmopolita, que en realidad suele esconder la etnocentrista, o, por decirlo con B. Santos (Santos, 1987) un «localismo globalizado». 
tro mercado de trabajo y ser fácilmente integrables porque están más próximos a nuestra cultura, a nuestra civilización, como ha defendido Azurmendi, quien, evidentemente, no comparte las tesis de Balibar o Castoriadis. Por eso se da hoy en Europa una tendencia a la preferencia por la inmigración del este o en todo caso por la latinoamericana, definidas como «integrables». De nuevo un análisis simplista de las diferencias culturales que parece ignorar la diversidad cultural que existe entre las sociedades latinas y las eslavas, o dentro de éstas últimas.

La integración no se persigue, pues, si se mantienen los fobotipos, el mecanismo de sospecha que hace de todo extranjero - hoy, el extranjero es el extracomunitario pobre - sujeto de sospecha y por ello, sostiene la consecuencia «natural» de que la discriminación en el trato, la no equiparación en derechos, está justificada. Que subsisten los fobotipos lo muestra, por ejemplo, algunas de las políticas de extranjería como, en el caso español, la ley 4/2000, incluso tras las sucesivas modificaciones (ley 8/2000 y ley 14/2003). Por ejemplo, su artículo 3.2 (sobre todo si se piensa que se suprimió el 3.3.), que lanza el mensaje de que las otras identidades culturales (al parecer, no la nuestra) son el origen de violaciones de los derechos humanos, o el modelo de reagrupamiento familiar del artículo 17 a), en el que se excluye un modelo de familia, como si nosotros tuviéramos a nuestra vez un único y necesario modelo. Dicho a las claras, toda diferencia cultural es sospechosa de incompatibilidad con los derechos humanos. Y esto se sostiene como si, por ejemplo, la violencia doméstica o el abandono de los ancianos - tan arraigados en ciertos hábitos culturales que son muy nuestros - no fueran atentados a derechos elementales. Lo cierto es que la mayor parte de las violaciones de derechos las sufren los inmigrantes, y no al revés, aunque sean tan cotidianas que resulten invisibles hasta que se produce el estallido. Los preceptos que transmiten fobotipos como ésos deberían desaparecer.

Por consiguiente, conviene ser precavido a la hora de hablar de interculturalidad. Para que haya interculturalidad en serio es preciso tomar en serio a su vez las otras culturas. No proyectar sobre ellas el estigma de inferioridad ni juzgarlas sólo de acuerdo a criterios culturales (los nuestros) identificados apriorísticamente como los únicos aceptables, los únicos civilizados, los únicos compatibles con las exigencias de la legitimidad democrática, es decir, con los derechos humanos y el Estado de Derecho.

Creo que no se puede hablar de interculturalidad si no existe la menor voluntad de conocer las demás culturas y, a fortiori, de reconocer el derecho 
a la identidad cultural de los otros. La reivindicación del derecho a la cultura en términos de derecho a la "propia cultura", en tanto que diferenciada (inevitablemente, minoritaria) pone el énfasis en un aspecto relativamente distinto, más específico, respecto al sentido que atribuimos al derecho a la cultura in genere. Mientras que este último es considerado como un elemento o incluso como una condición de la libertad y del desarrollo individual, esto es, como un requisito que hace posible la emancipación del individuo (en ese sentido, un requisito paralelo a la educación), el primero pone el acento en la dimensión comunitaria de la cultura y por eso las reivindicaciones del derecho no se detienen en el área de los derechos individuales, lo que constituye una de las razones fundamentales de su problematicidad. Es así precisamente porque en este caso lo relevante es la vulnerabilidad de la propia cultura, junto a la condición de precariedad que define a los grupos diferenciados - minoritarios en el sentido normativo: que se encuentran en una posición de inferioridad, de desigualdad, de perjuicio e incluso de discriminación- y a los individuos que forman parte de ellos.

Por supuesto que, además, hay un tercer factor que especifica el sentido de la apelación a la identidad cultural. Si tal identidad no aparece de forma expresa como contenido básico del derecho a la cultura hasta muy recientemente, es precisamente porque ésta, la cultura, se da por supuesta como un concepto pacífico, unitario, aún más, obvio: nuestra cultura. Sólo cuando se reconoce, o, mejor, cuando se toma en serio el fenómeno del pluralismo (concretamente del pluralismo cultural), es cuando se advierte la imposibilidad de mantener como idénticos el derecho a la cultura en el sentido genérico de acceso al bien de la cultura y el derecho a la identidad cultural, que aparecen confundidos en el planteamiento de homogeneidad cultural propio de los Estados nacionales hasta prácticamente ayer, pues se da por hecho que el Estado es monocultural, que compartimos una cultura. Es entonces cuando se da paso al plural: a las culturas, a la diversidad cultural. Con el incremento del pluralismo cultural, con el reconocimiento de que las nuestras son (siempre lo han sido, aunque sólo ahora es visible) sociedades multiculturales, es posible e incluso necesario distinguir: una cosa es el derecho al acceso y participación en la cultura como bien primario, en el sentido del acceso, participación y disfrute de la cultura, de la vida cultural, como requisito para el desarrollo y la emancipación individual. Otra, el derecho a la propia identidad cultural, al propio patrimonio y herencias culturales. En la primera, el objetivo es que todos 
seamos iguales. En la segunda, lo importante es la garantía de la diferencia y de que esa diferencia constituye igual punto de partida para participar en la vida pública, para constituirla.

Como he apuntado en otras ocasiones, las respuestas tradicionales ante el fenómeno de la multiculturalidad que sostienen esta tesis del riesgo para la democracia son las que se orientan a reforzar la homogeneidad en términos de identidad cultural, étnica o demográfica, la vía escogida por las políticas de asimilación impuesta y por las de segregación, propuestas tras las que se encuentra un reduccionismo bien conocido, el que sostiene el carácter imprescindible de la homogeneidad social como requisito para la pervivencia y estabilidad de cualquier grupo social. Asimismo, les subyace (el paradigma es la tesis de Huntington) la tesis de la incompatibilidad de convivencia de esos modelos culturales y del inevitable conflicto cultural. Obviamente, el corolario es la superioridad jerárquica del modelo occidental. Todo eso se traduce en medidas sociales, económicas y jurídicas que, a la vista de la incompatibilidad de las diferentes propuestas o identidades culturales (de la inviabilidad misma del multiculturalismo $\mathrm{y}$, a fortiori, de la propuesta intercultural), están presididas por el modelo de asimilación impuesta o en todo caso por el de segregación. Me parece indiscutible que esa visión, reproducida aquí esquemáticamente (y, por tanto, también rozando la caricatura), ha comenzado ya a ser admitida y puesta en práctica. Baste pensar también en cómo se analiza el fenómeno de la inmigración (especialmente el de origen africano, vinculado a la identidad musulmana) por parte de los países de la Unión Europea, y en las tímidas respuestas, a su vez, al crecimiento de las demandas de las minorías nacionales, étnicas o religiosas en los países de ese ámbito. Por eso el conflicto se centra en la incompatibilidad del modelo occidental con la cultura propia del fundamentalismo islámico, la más significativa y la más cercana.

\section{SOBRE LA CARACTERIZACIÓN DEL PROYECTO INTERCULTURAL}

De ahí la necesidad de precisar el proyecto intercultural que proponemos como solución. La interculturalidad como proyecto se articula, en mi opinión, en tres planos distintos: el ideológico o simbólico, en el que el papel determinante lo tienen los medios de comunicación y la educación (educación intercultural y mediación), tal y como ha desarrollado Carlos 
Giménez (1997), el normativo, en el que la clave es el discurso jurídico político (las nociones de ciudadanía inclusiva, por ejemplo en el modelo de ciudadanía diferenciada o multicultural, la soberanía compartida, la economía de codesarrollo son los instrumentos clave) y el de la praxis social, en la que de nuevo la educación y cierta ética pública son imprescindibles, junto a las medidas adoptadas en relación con el trabajo, la vivienda y la salud.

Como apunté antes, pocos como Carlos Giménez, desde los análisis de Young, Perotti o Lipjhardt, han trabajado eficazmente en señalar las condiciones del proyecto intercultural, y por eso seguiré sus propuestas en este punto. Para evitar los fracasos a los que se vieron abocados otros intentos de gestión de la multiculturalidad, para evitar el riesgo de que el proyecto intercultural aparezca como sucedáneo de la buena conciencia (ya saben: la ideología Benetton), que termine en folclorismo, en aditivo étni$\mathrm{co}$, en culturalismo, es preciso contextualizar el proyecto intercultural. Estamos en un mundo globalizado, en el que la hegemonía de un modelo (el que podemos sintetizar en la fórmula "MacWorld frente a la Yihad", propuesta por B. Barber), amenaza con hacer desaparecer toda diferencia.

La primera de las condiciones de la interculturalidad, la fundamental, es cierta simetría, cierto grado de igualdad de los interlocutores, que parece exigir, como en la propuesta de Habermas sobre universalismo moral, la asunción por cada cultura de su propia relatividad, lejos de todo esencialismo, de todo monopolio de la verdad o superioridad cultural dogmáticas, para posibilitar la convergencia. No hay diálogo intercultural sin igualdad en las posiciones de partida y eso es muy difícil de predicar hoy y por esa razón la primera queja es que con frecuencia los proyectos interculturales (como las políticas soi-disant multiculturales) no son más que una nueva coartada del etnocentrismo. Para asegurar esa condición sine qua non, Giménez ha propuesto vincular el debate intercultural al desarrollo (y al etnodesarrollo, como se ha propuesto a propósito de los derechos de las minorías), a la construcción de una ciudadanía inclusiva, a un modelo de poder compartido (quizá por la vía de la descentralización, de la importancia de los poderes locales y regionales o, de forma más ambiciosa, según propone Castells, por el modelo de sociedad-red, de estado-red). Dicho de otro modo, conciencia de la desigualdad en el punto de partida desde el que se plantea tantas veces el diálogo intercultural. No puede haber nada similar a esto cuando el acceso, la garantía y el desarrollo del poder y de la riqueza son 
tan desiguales precisamente en función de la diversidad cultural: la asimetría económica, de dominación, de acceso a la información y a los medios de difusión cultural, exige el reconocimiento de la asimetría en el primer paso, en el deber de conocer y dar a conocer las propias reglas de juego, las instituciones, valores y prácticas sociales relevantes, antes de exigir su cumplimiento incondicionado.

La segunda condición es el acceso simétrico a los medios de comunicación y formación de la opinión pública. Y en este sentido, la situación de hecho obliga a un diagnóstico teñido de escepticismo: ¿cómo podrían alcanzar condiciones de igualdad las culturas periféricas frente a la cultura global? ¿Puede ser su destino diferente de la desaparición o de su integración como glocalismo (localismo globalizado/globalismo localizado) en el mercado global?

La tercera condición, que se desprende de las anteriores es el esfuerzo por el mutuo conocimiento, que implica voluntad de conocimiento y superación del prejuicio de que todo lo que no es nuestro es barbarie...

La cuarta es la voluntad de reconocimiento de esas culturas y sobre todo de sus agentes: reconocimiento de los inmigrantes como sujeto jurídico y político, no como objeto de asistencia ni como mera herramienta.

La quinta, la voluntad de negociación, que es una condición de cualquier proyecto de construcción de una gestión democrática de las sociedades multiculturales: aceptar que todos podemos cambiar y que todos tenemos la palabra para proponer, negociar, decidir. Y ello supone también paciencia y atención a la complejidad: no hay recetas mágicas, no hay soluciones a corto plazo. Sí existe experiencia acumulada, fuera de nuestras fronteras, en particular en Holanda, Francia e Italia, más que en el Reino Unido o la República Federal Alemana y también dentro, en los planes municipales y en algunos planes autonómicos.

Pues bien, entre esas condiciones previas al proyecto intercultural, se encuentra la tarea del Derecho. Y también una determinada noción del contrato político, más allá del contrato social.

\section{LAS CONDICIONES JURÍDICAS DEL PROYECTO INTERCULTURAL}

No desconozco la objeción frecuentemente formulada por quienes se plantean si son el Derecho, las leyes, los derechos, las reglas de juego, los procesos jurisdiccionales y administrativos la vía idónea para la integra- 
ción social y para la interculturalidad y aun cuestionan que tenga sentido una «ley de integración» de quienesquiera que sea. No es nada raro escuchar por parte de algunos de nuestros responsables políticos, que, en efecto, esas no son una cuestiones jurídicas, sino sociales. Evidentemente, no les falta razón si lo que se trata es de descubrir el Mediterráneo, de que como proceso social complejo no pueden reducirse a una dimensión como la legal o, para decirlo mejor, la jurídica. Pero si lo que se pretende decir es que el Derecho sólo puede y debe aspirar a garantizar a posteriori las condiciones y procesos sociales que hacen posible la integración, esos argumentos no merecen el chocolate, sino una reprimenda y una descalificación.

Semejante planteamiento es el que se sostiene también cuando se aduce que la integración no tendría o, al menos, no dependería básicamente de condiciones jurídicas, porque es una cuestión cultural, o económica, o de la vida cotidiana, y que, en todo caso, la integración es cuestión y competencia de la sociedad civil, de los agentes sociales y por tanto el Derecho y el Estado deben mantener una estricta posición de neutralidad, de no interferencia (hands-off) para no perturbar ese protagonismo, esa responsabilidad.

La respuesta a estos planteamientos es muy sencilla y pasa por denunciar la falacia argumentativa, una falacia que es muy coherente con cierta más que rancia concepción del liberalismo, por más que pretenda modernizarse arrojando al otro lado la descalificación de paleolítico intervencionismo estatalista. En efecto, contra lo que viene insistiendo el discurso oficial a propósito de los «errores de leyes desmesuradamente generosas que pretender imponer la integración y crean así el conflicto", hay que decir muy alto y muy claro lo contrario: los derechos, su reconocimiento, no crean el conflicto, no crean la reacción del racismo y la xenofobia, sino que constituyen la condición previa, necesaria aunque, desde luego, insuficiente, para que haya una política y una realidad social de integración.

Dicho de otro modo: para que tenga sentido hablar de integración hay que comenzar por algo previo a los programas de interculturalidad, a las políticas de valoración positiva de la diversidad, a la lucha contra el prejuicio frente al otro. Y eso previo es la seguridad en el reconocimiento y satisfacción de las necesidades básicas de todos. Un elemento previo que significa reconocer y garantizar a todos los seres humanos los derechos fundamentales (aquellos derechos humanos que predicamos como universales) que son la vía de satisfacción de tales necesidades. Si no, estamos 
hablando de otra cosa cuando hablamos de derechos. Ya no hablamos de aquellos instrumentos que sirven para la emancipación de los seres humanos como agentes morales, como únicos sujetos de soberanía, sino de las coartadas para asegurarnos la obediencia mecánica y la pasividad de los súbditos, de la masa. Y es que a veces cuando hablamos de integración y derechos estamos pensando en otro modelo.

Otro modelo, sí: aquel en el que la integración es el ingreso en un corral en el que nuestra marca de hierro son esos derechos-mercancía, que traducen un consenso ajeno a nuestra voluntad y a nuestra capacidad de decisión, a nuestra autonomía, a nuestra libertad. Integración en un cuerpo supuestamente homogéneo en el que está muy claro lo que es bueno y lo que no, porque lo primero está recogido en la Constitución y lo segundo en el Código penal, y no hay discusión, ni dudas ni, menos aún, posibilidad de cambiar éste o aquella. Ese es el modelo de quienes piensan que de un lado está la democracia occidental, el mercado y los derechos universales y de otro la barbarie. De forma que lo que hay que exigir al bárbaro es que se despoje de sus costumbres, instituciones y reglas repugnantes para la dignidad humana, la democracia y el mercado y se integre, o, mejor aún, comulgue en esas reglas de juego que nos hacen superiores, libres e iguales.

Dicho de forma más concreta, el camino jurídico áureo que llevaría a la integración sería el que supone la más absoluta renuncia a cualquier manifestación de pluralidad en serio. Y ello demuestra que quienes así lo sostienen (aunque se proclamen y probablemente lo crean de buena fe, demócratas inequívocos) jamás han tomado en serio ni la libertad, ni la igualdad, ni el pluralismo. Presos no ya de un complejo etnocéntrico, sino de un auténtico complejo de Procusto, realizan una tan simplista como falsa ecuación de identidad entre valores jurídicos universales, Estado de Derecho y democracia con costumbres e intereses de los grupos de poder que hegemonizan y homogeneizan nuestras denominadas sociedades de «acogida».

Lo que sucede es que incluso esa cínica respuesta entraña no pocos problemas, empezando por la concreción de los derechos cuyo reconocimiento vendría así exigido como condición previa de la integración. Es una opinión comúnmente repetida, a ese propósito, que ese reconocimiento, en el caso de los inmigrantes, de los extranjeros, de los diferentes visibles (aunque sean nacionales: mujeres, minorías étnicas o culturales o nacionales o religiosas, niños, discapacitados, etc.), recorre un camino inverso al de la 
positivación de los derechos humanos: en este caso, los derechos civiles son primero, sí, pero luego vienen los económicos, sociales y culturales y sólo muy al final los políticos. En mi opinión, la única regla admisible es la igualdad y la plenitud en el reconocimiento de derechos, con prioridad para los imprescindibles para la integración: educación, sanidad, trabajo, vivienda y libertades.

En realidad, las cosas son más duras todavía: suponen una doble restricción del camino del reconocimiento jurídico. Ante todo, a) la restricción que hace del otro-inmigrante un no-sujeto jurídico, porque por definición ("por naturaleza») no es ni puede ser miembro de la comunidad política y jurídica, no puede crear derecho, sino sólo sufrirlo. Por eso el inmigrante no puede tener (iqué disparate!) derechos políticos, ni siquiera en el ámbito municipal, si no es en régimen de correspondencia o reciprocidad... Hasta que no se ha «naturalizado» hasta que no ha dejado de ser él, no podemos creer en su integración. Sólo los hijos de sus hijos, cuando se haya borrado la huella de su comunidad de origen, la huella de la evidencia de su no-pertenencia al nosotros (y eso en realidad nunca será del todo así) podrán aspirar a ser ciudadanos de verdad. Además, b) restricción porque imposibilitan que el no-sujeto llegue a ser sujeto, pues el primer y devastador efecto de tales "políticas» es desestabilizar, deslegalizar, desintegrar a quienes aspiran a la estabilidad, a la legalidad, a la integración.

Esa condición de no-sujeto y esas trabas en su camino por llegar a ser sujeto se concretan en los elementos que caracterizan el contrato de extranjería en la permanente contrarreforma del Gobierno del pP en materia de inmigración:

1. La prioridad incondicionada de los deberes respecto a los derechos: al inmigrante se le exige ante todo cumplimiento de deberes, testimonio fidedigno de que no va a poner en peligro nuestra comunidad, nuestros valores, nuestro consenso; ante todo, debe hacer expreso que acepta las reglas de juego (aunque no pueda ni siquiera conocerlas porque nadie se las ha explicado, pues, pese a los apóstoles del efecto llamada, la ley de extranjería no es la lectura obligada en el Tercer Mundo). Ese planteamiento ignora la asimétrica relación de poder que se da entre el otro-inmigrante y nosotros-ciudadanos (o sociedad de acogida, como se dice). La lógica igualitaria exige tener en cuenta tal asimetría a la hora de imponer obligaciones, reconocer derechos y manejar medios para uno y otro fin. Y sobre todo, exige 
el previo conocimiento de los deberes: la situación de partida del inmigrante pone de manifiesto la deficiencia del principio ignorantia legis non excusat. La situación de asimetría entre la sociedad de destino y los inmigrantes justifica a mi juicio que se pueda sostener la existencia de una obligación de aquella para que éstos adquieran ese conocimiento. Por otra parte, hay que hilar fino a la hora de hablar de deberes. A mi juicio, más allá de la Constitución y la legislación ordinaria (simplificando, el Código Penal) no es exigible para los inmigrantes ningún tipo de deber específico, en particular por lo que se refiere a «nuestras costumbres» o «nuestro modo de vida». Lo contrario significa una discriminación respecto a los nacionales y, además de violar el principio de igualdad de trato, rompe con la exigencia de respeto del pluralismo. ${ }^{3}$

2. La inversión del principio de inocencia (clave del garantismo como núcleo del Estado de Derecho): el inmigrante debe demostrar de continuo que no es una amenaza, un peligro, una patología, un cuerpo extraño e incompatible cuya presencia no puede no generar rechazo, desestabilidad, imposibilidad de convivencia. Ese es el discurso de los cupos, incluso so capa de un pretendido respeto al imperio de la ley y del derecho que exigiría, ante todo, acotar la estigmatizada categoría de irregular, con la coartada de que es para su propio bien: para evitar males mayores, para poner límite a la xenofobia y al racismo, para evitar que la realidad desborde la norma, discurso que inspira a los angélicos diseñadores del plan GRECO (angélicos porque para ellos las medidas presupuestarias son innecesarias: todo el bien se producirá automáticamente al presentar ese elenco/refrito de medidas ya existentes e ineficaces hasta ahora) y a los no menos benéficos pergeñadores del «Pacto de Estado a toda costa», porque lo que importa es aparecer como estadistas consagrados al interés superior del Estado, más allá de la horrorosa etiqueta de partidistas, sobre todo de partidistas de la defensa de los derechos de los inmigrantes, terrible etiqueta de notable costo electoral. Y por si no me he expresado con claridad, me refiero a los dirigentes del PSOE que en aras del "Pacto de Estado de inmigración", pueden acabar defendiendo un Pacto de razón de Estado sobre el terrorismo y contra la inmigración.

${ }^{3}$ La pregunta por ejemplo acerca de las condiciones de reconocimiento como sujeto de derecho, que en el caso de los inmigrantes conduce a los test de integración, en los que no es difícil advertir elementos de etnicidad en lugar de patriotismo constitucional: ¿qué exigir? ¿La lengua, la memoria, la historia? ¿La Constitución, el Código penal, el de circulación? 
3. La anulación del principio de la seguridad jurídica sin el que no hay respeto a los derechos humanos. Porque la seguridad jurídica no es el discurso del orden, sino la garantía en el reconocimiento y disfrute de las libertades, y si algo caracteriza el discurso acerca del status jurídico del otro-inmigrante es la precariedad en el reconocimiento (sólo parcial, sólo sectorial, sólo durante un tiempo, mientras se tenga la condición de trabajador formal) y en el disfrute de las libertades (puesto que se incentiva la discrecionalidad si no incluso la arbitrariedad de la administración: se desdibuja el control de los actos de la administración respecto a derechos de los inmigrantes, se altera el régimen de silencio administrativo, se elimina el requisito de motivación de los actos de la administración, justamente de aquellos más decisivamente limitadores de derechos, como lo muestra el régimen de denegación de visados), etc.

4. El abandono descarado del principio de igualdad en los derechos humanos por encima de la lotería genética, es decir, la reiteración del principio de preferencia nacional en el ámbito de los derechos humanos (es lo que muestra el artículo 3 de la contrarreforma, como ha puesto de relieve el muy morigerado informe del CGPJ).

En resumen, el Derecho debe garantizar aquí también el cumplimiento de tres objetivos básicos: seguridad jurídica, igualdad e inclusión. Si los instrumentos del derecho van encaminados a configurar un status de incertidumbre y vulnerabilidad, un status de segmentación de derechos y de discriminación injustificada de trato, un status de subordinación, si continúa siendo un instrumento para ver el velo en la cabeza ajena pero no la mantilla en la nuestra, el Derecho se convierte en un instrumento ilícito.

\section{LAS CONDICIONES POLÍTICAS DEL PROYECTO INTERCULTURAL}

Claro que el problema fundamental es que mal se puede hablar de integración e interculturalidad en serio cuando el programa de creación de la comunidad política está marcado por tres reducciones: a) la mencionada preferencia nacional, que excluye - hace impensable-que pueda ser miembro quien no ha nacido en la comunidad; b) la negación del pluralismo en aras de un complejo de Procusto y que sigue entendiendo la comunidad política en los términos schmittianos que exigen la existencia del 
otro como enemigo para que podamos hablar del nosotros, de los ciudadanos-amigos-familia; y finalmente c) una vieja concepción de la política que, o bien reduce la condición de ciudadano/soberano/miembro activo de la comunidad a los nacionales ricos, conforme al síndrome de Atenas, o bien entiende la democracia en términos shumpeterianos-mercantilistas, como un marco formal en el que los clientes tratan de obtener la mejora de sus preferencias y asignan poder en función de las aptitudes de los políticos-profesionales para optimizar esos intereses que les mueven a jugar en el mercado.

Hablo, desde luego, de una noción de comunidad política que quizá no se ajusta a la caracterización habitual de la democracia. Se trata de una democracia inclusiva, plural, consociativa e igualitaria. Una democracia basada, a su vez, en una noción de ciudadanía abierta, diferenciada, integradora.

Una comunidad política así entendida exige, en mi opinión, plantear como reivindicaciones irrenunciables de toda política de inmigración que pretenda ser acorde con los principios de legitimidad democrática y de respeto a los derechos humanos, al menos las tres siguientes:

1. La condición de miembro de la comunidad política no puede ser un privilegio vedado a quienes no tuvieron el premio de la lotería genética. El modelo de democracia inclusiva exige un cambio en las oportunidades de alcanzar esa membership. No sólo de llegar, de acceder, sino de pertenecer. Insisto. La primera reivindicación es el reconocimiento y satisfacción del derecho de acceso, de las vías que hacen posible el acceso a la condición de miembro de esa comunidad, de nuestras comunidades, y eso se ha de traducir en la adopción de un abanico de medidas que hagan posible ese reconocimiento y esa garantía. La clave de esta política, si quiere merecer el adjetivo no ya de integradora, sino de conforme a los principios de legitimidad que supone el respeto a los derechos, más incluso que el grado de reconocimiento de derechos (de huelga, de asociación, de reunión, etc.) son las condiciones de acceso a la comunidad, las vías para llegar a ser miembro. Y lo primero a su vez es cómo entrar: por lo tanto, las condiciones de entrada y permanencia, las condiciones de regularización y participación en la vida pública en términos de igualdad son condiciones sine quae non. Por esa razón, antes que los derechos políticos, el rasero para medir una política que dé la talla es, por ejemplo, el procedimiento de obtención y el control de denegación de visado, la supeditación de la 
entrada al sistema de cupos y la utilización de los procesos de regularización. Lo es también el sistema de dependencia inexorable entre permiso de residencia y de trabajo que aherroja la ciudadanía en el trasnochado molde del trabajo formal.

2. Pero una vez que se entra, es necesario adoptar medidas que impidan la existencia de un muro infranqueable para quien llega y quiere convertirse en miembro de esa comunidad. Entre las condiciones que responden a ese objetivo se encuentran, evidentemente, algunos de los medios de acceso a la integración social: vivienda, educación y trabajo. La responsabilidad básica aquí compete a la administración municipal y regional o autonómica, pero a esa responsabilidad debe dársele la contrapartida de medios y de competencias. Y quiero dejar claro que todavía no me refiero a la garantía de esos derechos. Hablo de problemas previos, como del modelo de alojamiento de los temporeros (el modelo de diseminación espacial puesto en práctica en El Ejido, como han explicado con claridad los trabajos de Ubaldo Martínez Veiga, Emma Martín Díaz o Ángeles Castaño por ejemplo). Los antropólogos saben muy bien la importancia de la organización del espacio. Saben muy bien y nos han explicado cómo hacer imposible lugares de reunión de los inmigrantes entre sí es aún más eficaz que dificultar su acceso a los espacios micropúblicos en condiciones que debieran ser evidentes en una sociedad que se dice pluralista. Hablo de las condiciones de trabajo y de la escasez de informes y actas (a fortiori de sanciones) practicadas por la Inspección de trabajo. Hablo, claro está, de condiciones que exigen medidas presupuestarias y previsión al menos a medio plazo.

3. Y por fin, obviamente, el reconocimiento en condiciones de igualdad (nada de tolerancia) de los derechos. De los derechos personales, de las libertades públicas, de los derechos económicos, sociales y culturales, pero obviamente y sin zarandajas de utopías, de los derechos políticos. Desde luego, en el ámbito municipal y autonómico me parece inexcusable el reconocimiento de la titularidad de soberanía de la comunidad local, extendida a quien reside en esa comunidad, es decir, que la condición de vecinos debe dar derecho a la plena participación política, que incluye, pero va más allá, del derecho al sufragio activo y pasivo a escala municipal. Pero hay que ir más allá de los Ayuntamientos y de las comunidades regionales o autonomías. Más allá incluso del Estado: lo que necesitamos, de verdad, es un estatuto que reconozca y garantice esos derechos en todo el espacio de la Unión Europea. Es necesario un estatuto jurídico de igual- 
dad de derechos de los inmigrantes no comunitarios en la UE, que acoja los principios propuestos o, al menos, que acepte su discusión y no los excluya a priori como inconcebibles.

\section{¿Concluyendo? Algunas Propuestas Para facilitar EL PROYECTO INTERCULTURAL}

Creo que estos datos hacen concluir que es muy difícil ser optimista sobre el proyecto intercultural, al menos en la escala macro. Este no puede consistir (ni siquiera en el terreno educativo) en el milagro seudoespontáneo de una suerte de Arcadia o Babel originaria donde Nemrod reina sobre todas las culturas que conviven en armonía. No basta con yuxtaponer todas las diferencias culturales. Hay que dar oportunidad para el diálogo y para el juicio y ahí reside la dificultad.

En todo caso, es posible establecer algunos criterios, ciertamente mínimos, pero también por esa razón eficaces.

En primer lugar, parece difícilmente discutible que, si aceptamos como un bien digno de protección jurídica los valores y la cultura propios de las minorías, se trata de garantizar su supervivencia y desarrollo, y eso requiere en muchos casos medidas del tipo de sanciones positivas y aun de lo que conocemos como discriminación inversa. ${ }^{4}$

Ese criterio, que está lejos de resolver las dificultades que se presentan de hecho, supone, entre otras cosas, que el planteamiento del problema en los términos que ya hemos mencionado (asimilación versus gueto) falsea el debate. De lo que se trata es de integración, no de asimilación. Entiendo por integración un proceso guiado por el objetivo de la equiparación en el reconocimiento jurídico, en la ciudadanía, lo que no supone clonación, sino igualdad en la diferencia. Al contrario, el modelo de asimilación condiciona el reconocimiento de los derechos a un proceso de mimetización respecto a la mayoría, lo que conduce al sacrificio indiscriminado de esas diferencias. En otras palabras: en mi opinión es muy difícil justificar ese modelo de asimilación si inevitablemente supone como de hecho, antes o

${ }^{4}$ Sobre discriminación inversa debe consultarse el ejemplo clásico del caso De Funis us. Odegaard, que es objeto de una reflexión de consulta imprescindible en Dworkin (1984), p. 327 y ss. Cfr. también el estudio de la técnica de sanciones positivas o normas «premiales» en Facchi (1991) y Ruiz Miguel. 
después, así sucede -aculturación y aun pérdida de elementales rasgos de identidad (de lengua, étnicos, religiosos, de organización social, etc.), ${ }^{5}$ aunque no cabe olvidar que hay procesos de asimilación voluntaria. ${ }^{6}$

El segundo criterio es asimismo elemental: el respeto a la diversidad no puede suponer menoscabo de los derechos fundamentales, ni de las reglas de juego propias de la legitimidad democrática y, entre ellas, que siempre que se respete el derecho de participación de todos en la toma de decisiones jurídico políticas y en los resultados (una segunda instancia en la que, ciertamente, como recuerda E. Díaz, ${ }^{7}$ se insiste menos), la concreción de la legitimidad democrática se encuentra en la voluntad de la mayoría. Dicho de otro modo, no hay integración posible si no se acepta la primacía del respeto a los derechos, porque son ellos los que constituyen el mínimo común denominador en el que es posible el reconocimiento. No se puede renunciar a ese mínimo sin echar por tierra la legitimidad jurídica y política. No es posible admitir ninguna diferencia, ningún (pretendido) signo de identidad propio que resulte irreconciliable con esos derechos, ${ }^{8}$ sin eliminar precisamente lo que hace posible el proceso de reconocimiento.

La interculturalidad no será más que una cáscara vacía hasta que los pueblos de Europa no tomen en serio la advertencia de Condorcet en el período $10^{\circ}$ de su Esquisse, contra el colonialismo y el paternalismo: «los pueblos aprenderán que no pueden convertirse en conquistadores sin perder su propia libertad». O, por remontarnos algo más, si no tratamos de evitar que pueda decirse de nosotros aquello que cuenta Montaigne al

${ }^{5}$ Máxime cuando en no pocos casos detrás de la asimilación hay únicamente razones de eficacia o maximalización de beneficio.

${ }^{6}$ Como recordaba Barry (1991), p. 17, a propósito de un análisis del punto de vista escéptico y liberal de los derechos, detrás de los fenómenos de conversión religiosa, en no pocos casos, subyace lo que los norteamericanos llaman las trading up denominations que permiten escalar en el status social (ser presbiterano, o episcopaliano), o el deseo de asociarse a una cultura más poderosa.

7 El mismo Elías Díaz es quien insiste en que la primacía de las mayorías (cuyo único límite es el respeto de los derechos) debe ser vista desde la perspectiva de la universalidad, siempre que ésta no se entienda en términos de universalidades ideales, en las que -extrema se tangunt- no acaba habiendo diferencia perceptible entre los fundamentalismos y las comunidades angélicas.

${ }^{8} \mathrm{Y}$ desde luego no estoy pensando en supuestos de laboratorio: prácticas (que responden a determinadas identidades culturales y religiosas) y que suponen la exclusión de la mujer del acceso y ejercicio en condiciones de igualdad en derechos como la educación, la libertad sexual, o la participación política son ejemplos de esa incompatibilidad. 
final de su Ensayo sobre los caníbales: los salvajes en visita en Ruán, en tiempos de Carlos IX, se asombran de que hombres hechos y derechos sirvan a un niño y, como en su lengua se llama a los hombres «la mitad» los unos de los otros, expusieron que habían advertido que había entre nosotros personas llenas y hartas de toda clase de comodidades, mientras sus mitades mendigaban a sus puertas, demacrados por el hambre y la pobreza. Y les asombraba que esas mitades menesterosas tolerasen tal injusticia y no asiesen a los otros por el cuello y los quemaran en sus casas. 


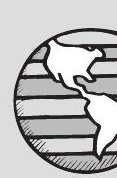

3.

Movimientos de población en la sociedad global

Mercedes AlCAÑIZ 
Los desplazamientos de los seres humanos a lo largo y ancho del planeta caracterizan nuestra historia. Tenemos ancestros comunes, los expertos dicen que todos venimos de África, por lo que resulta obvio que nuestra especie no ha parado de moverse desde tiempos inmemoriales bien sea a la fuerza o de forma voluntaria, andando, sobre animales, navegando, o sobre tecnologías construidas como el carro, el automóvil, el tren, el avión...

Desde África, los movimientos de los primeros humanos se dirigieron hacia Asia central, Europa... y más tarde 1legaron a Australia y América. Así realizamos la conquista del mundo, moviéndonos continuamente y descubriendo nuevos lugares donde asentarse. Los paleontólogos van añadiendo nuevos datos al rompecabezas de nuestros primeros momentos como especie.

Ya en la actualidad, deberíamos pensar quien de nosotros no es migrante; si nos remontamos a dos o tres generaciones es muy probable que muchos contemos con algún antecesor llegado de otro lugar más o menos lejano. Y quien no nos dice que alguno de nuestros descendientes se traslade a tierras en las antípodas de donde vivimos.

Con la Modernidad, los movimientos se hicieron más visibles y también más numerosos. El descubrimiento de un nuevo continente, la circunvalación al mundo y la importancia que iba adquiriendo el comercio como nuevo sistema económico, condujeron a que grupos de europeos decidieran desplazarse hacia otros lugares en los que pensaban que podrían obtener ventajas y mejoras de diversos tipos. Estos primeros desplazamientos masivos tuvieron como consecuencia el poblamiento europeo de las nuevas tierras "conquistadas", como el continente americano y Oceanía principalmente, sin olvidar el genocidio cometido con las sociedades que allí habitaban con anterioridad. 
Con la expansión del capitalismo como sistema económico mundial, así como la mejora en rapidez de los transportes y de los medios de comunicación, la población mundial está en continuo movimiento y en continua relación.

Desde el Neolítico, el sedentarismo se ha constituido en la forma predominante en prácticamente la mayoría de sociedades de nuestro tiempo. No obstante, las personas que habitan en el Norte rico, se mueven también para cumplir con lo que parece ser un destino genético humano como es el deseo de movimiento: nos referimos al turismo global, que va en aumento y se ha convertido en un negocio lucrativo con grandes ganancias. Según datos de la Organización Mundial de Turismo sobre el turismo global, se cifra en 763,2 millones los turistas en 2004, siendo la media anual de crecimiento de un 6,5\% (fuente: OMT, www.world-tourism.org).

El tiempo libre se ocupa en viajar, moverse se ha convertido en una actividad de «divertimento» que no tiene nada que ver con los desplazamientos realizados para la búsqueda de mejores posibilidades de vida y mucho menos con los forzados.

El objetivo de este capítulo se centra principalmente en exponer los movimientos de población actuales vinculándolos con aspectos que definen la sociedad global predominante en el presente. Para ello, daremos en primer lugar un breve repaso histórico a los principales movimientos migratorios que acaecieron anteriormente, con la finalidad de señalar la interconexión entre tipos de desplazamiento y tipos de sociedad, subrayando de este modo la historicidad de los movimientos de población. Seguidamente, centrándonos en la actualidad, comentaremos los traslados que tienen lugar en el presente, las causas y los prototipos de desplazamientos siguiendo las clasificaciones establecidas en organismos internacionales e investigaciones científicas con el fin de exponer el amplio abanico de movimientos de población que se realizan en la sociedad global.

LOS MOVIMIENTOS DE POBLACIÓN: BREVE REFERENCIA HISTÓRICA

No es nuestro objetivo realizar una exposición exhaustiva sobre los movimientos de población que han sucedido a lo largo de nuestra historia, sino proceder a dar una breve referencia de los acontecimientos más notorios relacionados con este hecho vinculándolos con la sociedad del 
momento. Es decir, que partimos de la idea de la íntima relación entre movimientos de población o migraciones y sociedad histórica.

Antes de iniciar la exposición, daré una concisa aclaración conceptual sobre los términos utilizados y el porqué de su elección.

El término migraciones se refiere a uno de los fenómenos sociales con más presencia en los medios de comunicación, en los debates científicos sociales de la actualidad e incluso en las conversaciones cotidianas. Sin embargo, no existe una definición operativa y definida que nos permita diferenciar claramente a qué hace referencia exactamente.

La UNESCO define las migraciones como «los desplazamientos de la población de una delimitación geográfica a otra por un espacio de tiempo considerable o indefinido». Definición ambigua, ya que no especifica la duración del desplazamiento y la delimitación geográfica a traspasar.

Desde un punto de vista demográfico, en la medida en que modifican el tamaño y la estructura de las poblaciones de origen y de destino, las migraciones son uno de los tres componentes del cambio demográfico en una sociedad, junto con la fecundidad y la mortalidad, siendo el más difícil de conceptualizar, medir y analizar.

En las estadísticas de los estados, la población no nacional consta como extranjera mientras que en el lenguaje cotidiano inmigrante ${ }^{1}$ conlleva una carga peyorativa negativa que incluye el proceder del sur pobre y ser culturalmente "diferente», mientras que los extranjeros son los oriundos de otros países pero casi siempre ricos y étnicamente más similares a «nosotros".

He preferido utilizar el término movimientos de población al de migraciones, aunque ambas tengan el mismo significado; desplazamiento, porque considero que este concepto incluye todos los tipos de desplazamiento que se realizan en la actual sociedad global, mientras que migraciones queda instantáneamente más vinculado con inmigración y la connotación negativa que conlleva.

En el caso de utilizar en alguna ocasión el término migraciones lo haré como sustitución de movimientos de población para no ser repetitiva o porque así consta en algún documento internacional enumerado.

${ }^{1}$ Hace décadas la palabra estigmatizada era «emigrante» ya que hacia referencia a las personas que por carecer de recursos en España tenían que partir hacia otros lugares para buscar el sustento. Los cambios acaecidos en la economía española han llevado al cambio en la situación con respecto del hecho migratorio. 


\section{La expansión europea por el mundo}

Los desplazamientos anteriores a la época moderna europea, fueron en su mayor parte debidos a conquistas militares ${ }^{2} \mathrm{o}$ expansiones religiosas ${ }^{3} \mathrm{O}$, como en el caso de la expulsión de los judíos y moriscos de España, por mantener la unidad religiosa y étnica en el recién creado Estado español. Los perdedores eran en muchas ocasiones tomados como esclavos y con respecto a los ganadores se producían traslados de población con el objetivo de colonizar el territorio conquistado.

Poca gente viajaba y se trasladaba de lugar de residencia por su propia elección; en el mundo de entonces todo se encontraba muy distante, porque las comunicaciones y los transportes estaban todavía poco desarrollados.

Uno de los acontecimientos más importantes en lo que iba a ser posteriormente el proceso masivo de población, fue el «descubrimiento» ${ }^{4}$ del Nuevo Mundo y los posteriores viajes que navegantes españoles, portugueses e ingleses mayoritariamente iban a realizar a lo largo y ancho de todo el mundo.

La expansión europea producida como consecuencia de los descubrimientos originó la creación de zonas de poblamiento europeo allí donde antes existían etnias indígenas y que fueron eliminadas o subyugadas por el conquistador europeo que se consideraba a sí mismo superior.

Paralelo a este proceso de traslado de población europea hacia las nuevas zonas se produjo otro que reubicó a personas del continente africano hacia el continente americano como esclavos para trabajar en las plantaciones y así servir de mano de obra a los «colonizadores europeos». Se estima que durante este período, entre 15 millones (Blanco, 2000) y 20 millones (Simon, 2002) de esclavos africanos fueron trasladados al continente americano a la fuerza, literalmente raptándolos desde sus tribus o comunidades. Algo que hoy se consideraría inaudito por el derecho internacional y los derechos humanos y que cuestiona sin duda alguna la consideración que de «superiores» tenían de sí mismos los europeos.

${ }^{2}$ Cualquier libro de Historia nos narra perfectamente las guerras y traslados de población que se produjeron durante siglos y siglos.

3 Sobre todo las religiones cristiana y la islámica.

${ }^{4}$ El término ya conlleva una carga eurocéntrica evidente ya que obviamente las nuevas tierras encontradas ya existían con anterioridad y lo único que hicieron los europeos fue descubrirlas para ellos mismos, es decir, conquistarlas, someterlas e incluso eliminarlas. 
Así pues, el período comprendido entre los descubrimientos y los inicios de la industrialización supuso, en cuanto a movimientos de población, una expansión de la población europea hacia otros lugares que cambiaron su paisaje étnico y su cultura ancestral para, a partir de entonces, estar poblados de blancos, cristianos y de cultura europea.

Los desplazamientos fueron al principio reducidos porque, además de ser pocos los barcos que podían realizar semejante trayecto, los viajes eran largos, las condiciones malas, así como los altos riesgos de enfermar en el viaje contribuían a desanimar a muchos de los aventureros.

Ahora bien, cuatro son las explicaciones encontradas para entender porqué a partir del siglo XIX los desplazamientos aumentan a una velocidad exponencial:

- El inicio del proceso de industrialización y de desarrollo en Norteamérica y Europa necesitó de mucha mano de obra para ponerlo en marcha. Este proceso conlleva también la mejora en los medios de transporte, ya que junto a la industrialización se inició el proceso de innovación tecnológica.

- La caída de la mortalidad en Europa, ${ }^{5}$ primera fase de la transición demográfica, que supuso un incremento de la población en el continente y la necesidad de expulsar población hacia otros lugares.

- La aceptación como valor general en nuestra sociedad de la importancia de mejorar de situación, de progresar, lo cual justificaba la búsqueda de dicha mejora en otro lugar y consecuentemente el desplazamiento, aunque supusiera, como así fue, el abandono de las raíces y la socialización en otra cultura.

- El proceso de independencia de las colonias americanas que se constituían en estados independientes y estaban necesitados de más gente para poner el nuevo estado en marcha.

Entre 1850 y 1900, más de 25 millones de europeos abandonaron definitivamente el continente europeo (Dupâquier, 2002). Estados Unidos y Canadá recibieron a originarios de Gran Bretaña, Irlanda, Países Nórdicos,

${ }^{5}$ En Europa, la mortalidad comenzará a retroceder a partir del siglo XviII. Las hipótesis propuestas son: el progreso en la medicina, el aumento en las condiciones de vida e higiene, las alteraciones en la alimentación y la erradicación de la peste. El mayor retroceso se produjo entre 1870-1880, a partir de la revolución pasteuriana (Dûpaquier, 2002). 
Alemania y en menor medida de Italia, mientras que españoles, portugueses e italianos predominaron en América del Sur preferentemente en Argentina, Chile y Brasil, países extensos y con muchas oportunidades. ${ }^{6}$ A Australia marcharon fundamentalmente británicos; aproximadamente unos 766.000 salieron hacia aquel continente lejano.

Aunque en menor proporción, los europeos también se desplazaron a África del Sur, India, Indochina, Islas del Pacífico y África del Norte.

Durante estas fechas se produjo otro tipo de desplazamiento, en este caso forzado, realizado con motivo de la abolición de la esclavitud en Estados Unidos; nos referimos al traslado de habitantes de las colonias europeas asiáticas (indios y chinos mayoritariamente) en dirección a otros países de reciente colonización europea como mano de obra en la construcción del ferrocarril y de carreteras, así como en la industria.

De 1900 a 1914, la tendencia migratoria se reforzó todavía más ya que salieron de Europa entre 18/20 millones de personas, sobre todo de los Balcanes, Austria-Hungría, Rusia y los países del Sur. Los países que reciben a los migrantes siguen siendo los nuevos territorios como América y Australia/Nueva Zelanda. Así, en vísperas de la Gran Guerra, el número de europeos establecidos fuera de Europa podría ser de 160 millones, de los cuales 138 en el continente americano, 15 en Asia, 2 en África y 5 en Oceanía. Con la caída y desaparición de los antiguos imperios, se producen unos desplazamientos de población importantes hacia América que sigue siendo el continente que recibe los mayores contingentes de población y se convierte en un «crisol» de culturas ya que en él se encuentran todos los grupos étnicos del planeta: asiáticos, europeos, africanos, caucasianos, eslavos, etc.

Entre 1926 y 1930, todavía salen más de 4.300 .000 europeos para, a partir de 1931, reducirse los flujos considerablemente como consecuencia de la situación prebélica que se anunciaba en Europa y de la depresión económica en Estados Unidos.

\section{Nuevos actores en los flujos migratorios}

Después de la Segunda Guerra Mundial, entre 1947 y 1951, se restablece la emigración transoceánica siendo 460.000 el número medio anual de salidas, de las cuales más de la mitad bajo la protección de la Organización

${ }^{6}$ En estas fechas, México recibió menos población porque su situación política era más inestable. 
Internacional de los Refugiados y con dirección prioritariamente a Canadá, Estados Unidos, Argentina, Australia e Israel. Los motivos de los desplazamientos eran en este caso más políticos que económicos: los judíos europeos hacia el recién creado estado de Israel; los palestinos expulsados de su tierra por la creación del estado de Israel hacia Jordania, Siria, Egipto y otros muchos países; los españoles republicanos hacia Francia y luego hacia países latinoamericanos; los alemanes que vivían en zonas que pasaron a ser Polonia hacia la República Federal Alemana; muchos ciudadanos de Europa del este que quedó controlada por la uRss hacia Estados Unidos. Y un largo etcétera de desplazamientos que tuvieron que ver con las consecuencias de la guerra. En Asia las divisiones de Corea y de Vietnam motivaron muchos desplazamientos en el interior de estos países; asimismo ocurrió con la partición de la India en dos países, la India y Pakistán, separadas por motivos religiosos.

También por estas mismas fechas se produce un nuevo flujo migratorio debido a motivos laborales en el interior de Europa; nos referimos al que se produjo cuando los países centro europeos inician su desarrollo económico apoyados por las ayudas norteamericanas del conocido Plan Marshall, por lo que requieren mano de obra para apoyar la incipiente industrialización. De esta manera, numerosos trabajadores de los países del sur de Europa ${ }^{7}$ y de los Balcanes se desplazan hacia estos países con el objetivo de encontrar un puesto de trabajo y enviar dinero a sus países. Es el caso de los conocidos como "trabajadores invitados", y fue considerada como una migración dirigida ya que se ponían en contacto los países receptores con los emisores; en muchos casos, el traslado temporal terminó convirtiéndose en definitivo, pese a los fuertes controles que gravitaban sobre los trabajadores invitados.

En esta época se produjo el proceso migratorio de población de las antiguas colonias europeas hacia las metrópolis que constituyó la primera oleada migratoria hacia Europa de población de los países del sur, si bien, durante los años 50, Europa permanecía todavía como el principal polo de partida de la emigración mundial; muchos países europeos tenían saldo migratorio negativo (Simon, 2002).

Junto con estos desplazamientos de población, más o menos voluntarios, en su mayor parte por motivos económicos, y que desplazaban a

7 Como sabemos, España era uno de los países emisores de población trabajadora hacia el centro de Europa. En dicha época se creó el Instituto Nacional de Emigración. 
personas allende las fronteras de sus estados o en el interior de los propios estados, ${ }^{8}$ comenzó a producirse otro tipo de movimientos de población pero en este caso, de forma obligada: los refugiados y desplazados como consecuencia de conflictos bélicos o post-bélicos.

La Segunda Guerra Mundial originó el desplazamiento más numeroso de refugiados hasta entonces conocido: 40 millones de europeos se encontraban desplazados de sus hogares cuando concluyó la guerra. Los cambios en las fronteras anteriores y la nueva hegemonía soviética sobre el Este europeo contribuyó a que muchos ya no regresaran.

También en Asia se producen multitud de refugiados: la partición de la India en dos estados, India y Pakistán, originó un intercambio de 15 mi1lones de personas entre ambos. Lo mismo puede decirse de Corea y de Vietnam, si bien en estos casos por motivos políticos e ideológicos como efecto de la Guerra Fría que caracterizó a la sociedad internacional.

El mayor número de refugiados se dio en Palestina cuando, por decisión de las recién creadas Naciones Unidas, se constituye el Estado de Israel (1948) por lo que millones de palestinos se desplazaron hacia países limítrofes donde todavía continúan. El respeto por un pueblo perseguido no es motivo para expulsar a otro que ya estaba asentado allí; este problema, como sabemos, continúa hasta nuestros días.

Tampoco África se ha visto excluida de este proceso y el continente incluye cientos de miles de refugiados en muchos países como consecuencia del proceso de descolonización y de las revueltas sociales y luchas tribales que persisten todavía en muchas partes.

Los movimientos de refugiados, en muchos casos, son más crueles, ya que no están planificados, ni son voluntarios y normalmente se realizan a la fuerza y en un tiempo breve de tiempo porque suelen ir acompañados de situaciones dramáticas.

\section{La globalización de los movimientos de población}

Desde la década de los ochenta y sobre todo de los noventa, se han consolidado nuevas pautas migratorias vinculadas con los acontecimientos que cambiaron los parámetros de las relaciones internacionales existentes hasta el momento, hechos que han contribuido a que los movimientos de población asuman un nivel de globalización nunca visto en la historia.

\footnotetext{
${ }^{8}$ Me refiero a la migración rural-urbana que se produjo en esas fechas.
} 
La caída del Muro de Berlín, que supuso el fin del imperio soviético, propició la expansión del sistema capitalista en aquellos lugares que anteriormente habían tenido una economía estatal planificada; este hecho, junto el desarrollo de las tecnologías de la comunicación y de la información, el neoliberalismo y el proceso de deslocalización empresarial, han conducido a una globalización económica con grandes consecuencias en los movimientos de población.

Así pues, las nuevas formas de las relaciones económicas, políticas y sociales emergentes están cambiando fundamentalmente el carácter de las pautas de movilidad y los procesos de asentamiento.

Tres son las dimensiones en las que se percibe esta generalización del fenómeno migratorio en la actual sociedad global:

- El incremento en el número de migrantes: aunque las cifras relacionadas con los movimientos de población son siempre suposiciones, la información recogida habla de una evolución que va desde 75,9 millones en 1965, a 125 en 1995 y 175 en 2003 (ONU, 2004). Otro hecho diferente, comparado con épocas anteriores, es que los desplazamientos ya no son exclusivos de los países desarrollados sino que afectan a casi todas las zonas del planeta. En las cifras oficiales proporcionadas por los diversos organismos internacionales no se incluyen a los migrantes clandestinos, mucho más difíciles de medir pero es de sobra conocido que su número es elevado.

- La ampliación de las redes migratorias: en el caso europeo, se han incorporado como países receptores Italia y España y en menor número Portugal. Siguen predominando las redes sur-norte, las producidas en Asia con destino a los países productores de petróleo y en el interior de África por la inestabilidad política de la región. Con la caída del Muro de Berlín y el desmembramiento de la uRss, surgen nuevos flujos que van de este a oeste europeos.

- Y la diversificación de los tipos migratorios: no son sólo los migrantes laborales los que se desplazan con el objetivo de mejorar su calidad de vida, sino que surge otro tipo de desplazamientos como los originados por los conflictos bélicos o post-bélicos como los refugiados, los desplazados internos y los que solicitan asilo en otro país.

La brecha demográfica existente entre los países del norte y los del sur constituye otro factor explicativo en el incremento continuo de los 
movimientos de población: mientras que en los del norte se mantienen tasas bajas de natalidad y mortalidad, por lo que se está produciendo un envejecimiento acelerado de la población ${ }^{9}{ }^{9}$ en los países del sur la caída en la tasa de mortalidad no se ha visto compensada con el descenso en la tasa de fecundidad por lo que se ha producido un boom poblacional, ${ }_{1}^{10}$ caracterizado por un aumento sorprendente de las cohortes jóvenes, en edad de trabajar, que tienen que salir del país si quieren mejorar sus condiciones de vida. Por el contrario, en los países desarrollados, con bajas tasas de fecundidad y mortalidad, la mano de obra joven es cada vez más necesaria en el mercado laboral por lo que recurrir a mano de obra inmigrante se considera necesario.

Jean-Pierre Gonnot (El País, 30 noviembre 2004) pone de relieve que las ventajas de la inmigración para los países de acogida superan a las desventajas ya que Europa habría perdido 4,4 millones de personas entre 1995 y 2000 de no haber sido por los 5 millones de inmigrantes llegados durante ese quinquenio. En el caso español, uno de los países europeos con la población más envejecida, sólo la inmigración será capaz de aliviar parte de las cargas del Estado de Bienestar.

Ahora bien, en un contexto internacional diferente, las características de las migraciones mudan con respecto de las migraciones de la época de la industrialización (García Canclini, 2001); en éstas, la gran mayoría de desplazados de Europa a América o Australia no regresaban, dejaban sus raíces para acomodarse a la nueva sociedad emergente a la que se habían trasladado.

En los desplazamientos actuales, las personas pueden regresar o no, pero en cualquier caso siguen manteniendo contactos con sus lugares de origen facilitados por las nuevas tecnologías de la información y de la comunicación. ${ }^{11}$ Sin olvidar que la mejora y abaratamiento en los medios de transporte ha permitido que las personas desplazadas regresen a sus lugares de procedencia para pasar las vacaciones. ${ }^{12}$

${ }^{9}$ La esperanza media de vida en Europa es de 78 años mientras que en África es de 55 años (Pison, 2001).

10 La tasa de fecundidad en Europa es del 10\%; en África del 38\%o (Pison, 2001).

11 En el paisaje urbano de muchas ciudades se ubican numerosos centros de llamadas internacionales e internet.

12 España es camino de paso para los magrebíes que retornan a su tierra en verano, bien en coche cruzando el estrecho de Gibraltar, bien en barco desde distintos puntos del Mediterráneo español. 
Denominamos «comunidades transnacionales» al conjunto de procesos a través de los cuales las personas desplazadas forjan y mantienen múltiples relaciones sociales, que unen a las sociedades de origen y las de asentamiento. Así pues, las comunidades nacionales o étnicas no están ligadas exclusivamente a un territorio sino que también son cibercomunidades ya que están unidas a través de la «sociedad red» de la que nos habla M. Castells. Dichas comunidades mantienen su lengua, sus costumbres y las tradiciones del lugar del que provienen.

\section{TiPOlogía De LOS MOVIMIENTOS DE POBLACIÓN EN LA ACTUALIDAD}

En este punto trataremos los movimientos de población que se producen en el presente, centrándonos en las migraciones laborales, los refugiados y los desplazados, diferenciando estos dos últimos porque los primeros traspasan la frontera nacional de un estado y los otros no. Dejamos para otra ocasión los desplazamientos realizados por placer (turismo) o los realizados por personas mayores jubiladas hacia otros lugares con mejor clima o el movimiento que producen los cooperantes de ong de desarrollo.

\section{Migraciones laborales}

Hablamos aquí de los movimientos de población por motivos estrictamente laborales, los cuales se han globalizado y diversificado en las últimas décadas. Su medición es difícil porque cada país y cada organización ${ }^{13}$ tiene una definición de lo que es migrante y porque, con los movimientos de población motivados por el turismo, se hace todavía más difícil saber cuando una persona es un turista verdadero o alguien que entra como turista y se queda como irregular o a la espera de solicitar asilo o de encontrar algún trabajo que le permita finalmente regularizarse.

Junto con la dificultad de la medición se sitúa la carga semántica que conlleva y que conduce a que entendamos como inmigrante exclusivamente a los provenientes de los países pobres del Sur; no se incluye en esta definición a los extranjeros provenientes de otros países del Norte. Se habla,

13 Por ejemplo, la orT utiliza las siguientes fuentes para la elaboración de las estadísticas sobre migraciones laborales: los censos, los permisos administrativos y el recuento de entradas y salidas por las fronteras de un país. 
pues, de extranjeros y de inmigrantes (que también son extranjeros) pero la connotación es diferente, siendo más negativa en el segundo grupo «personas pobres que vienen a nuestro país a quitarnos el trabajo y que además son delincuentes y muy conflictivos». La memoria colectiva es débil y no recuerda que hace poco más de tres décadas los españoles éramos también inmigrantes en otros países europeos y que mucho antes lo fuimos en numerosos países latinoamericanos. Junto a prejuicios de tipo laboral, se sitúa un prejuicio más cultural y étnico, un rechazo al «otro», al diferente.

Así pues, con el incremento en las migraciones internacionales (no exactamente en el número sino en la extensión y la multiplicidad de grupos étnicos en movimiento) se produce un nuevo tipo de movimiento de población más globalizado, más intercultural ya que intervienen en los flujos migratorios más países que anteriormente.

El interés internacional por las migraciones comenzó con la creación de las Naciones Unidas: la Comisión de Población se creó el 3 de octubre de 1946 y entre sus objetivos estaba el estudio de los movimientos migratorios y de la población y los factores asociados a tales movimientos (Barata, 2003). Entre las competencias atribuidas a la Comisión se sitúa el estudio de los movimientos migratorios de población y los factores asociados a tales movimientos.

Diversos instrumentos internacionales creados en el ámbito del sistema de las Naciones Unidas manifiestan la búsqueda de medios para promover la protección de emigrantes, refugiados y desplazados. En los documentos aprobados en las conferencias de Bucarest (1974), México (1984) y el Cairo (1994), se incluyen recomendaciones en este ámbito.

Si bien y como reflejo de la diferente coyuntura internacional del momento, en las deliberaciones de Bucarest y México se recomienda la facilidad de las migraciones internacionales de trabajadores, consideradas de interés tanto para los países emisores como por los receptores. Sin embargo, en 1994 en la capital egipcia, se introduce el principio de la conveniencia de mantener dentro de los límites razonables los movimientos migratorios internacionales por lo que es deseable crear condiciones a través de políticas de desarrollo adecuadas, para reducir los incentivos de salida del país de origen.

El 18 de diciembre de 1990 se aprueba por la Asamblea General la Convención Internacional para la protección de los derechos de todos los trabajadores migrantes y los miembros de sus familias. Dicha Convención 
introduce en su artículo $2{ }^{\circ}$ una definición internacional de trabajador migrante y caracteriza diferentes variantes de esa condición:

Trabajador migrante es la persona que va a ejercer, está ejerciendo o estuvo ejerciendo una actividad remunerada en un Estado del que no es nacional.

El artículo 3. ${ }^{\circ}$ declara fuera del ámbito de aplicación de la Convención a las personas que se encuentran en el territorio de un Estado del que no son nacionales en las situaciones siguientes: al servicio de organizaciones internacionales o del Estado en misiones relacionadas con el desarrollo, a los establecidos como refugiados o apátridas, estudiantes o personas en formación, trabajadores marítimos y trabajadores de instalaciones offshore.

La Convención también habla del derecho que tienen los migrantes a recibir igual trato que los nacionales en lo que se refiere a remuneraciones y demás condiciones de trabajo. Asimismo, señala que los Estados donde los migrantes ejercen su actividad deben garantizar el respeto por su identidad cultural y no deben impedirles mantener sus lazos culturales con su Estado de origen.

Como afirman Castles y Miller (1998), la migración internacional jamás ha tenido tanta difusión ni ha sido tan importante en términos políticos y socioeconómicos como lo es actualmente. La seña de identidad de las actuales migraciones internacionales es su carácter global, afectando directamente a más y más países y regiones y unida a complejos procesos que afectan al mundo entero.

El creciente movimiento de personas en busca de trabajo, seguridad humana y mejora en las condiciones de vida ha exigido la atención de los responsables políticos y ha fomentado los diálogos entre gobiernos para encontrar soluciones a este hecho.

Es difícil precisar la magnitud total a escala mundial de tales flujos porque no todos los países contabilizan y comunican el volumen de la migración laboral pero se trata indiscutiblemente de un fenómeno considerable y en aumento. Según datos de la Organización Internacional del Trabajo (ОIT) se estima que hay actualmente más de 80 millones de migrantes laborales en el mundo. ${ }^{14}$

14 OІт (2004): En busca de un compromiso equitativo para los trabajadores migrantes en la economía globalizada, Informe VI. Conferencia Internacional del Trabajo, 92. ${ }^{a}$ reunión. 
Veamos en la siguiente tabla la distribución por continentes:

Cuadro 3.1. Distribución de los trabajadores migrantes en el año 2000 por continentes

\begin{tabular}{lcr}
\hline CONTINENTE & TRABAJADORES (EN MILLONES) & $\%$ \\
\hline África & 5,4 & 7 \\
Asia & 22,1 & 27 \\
Europa & 27,5 & 34 \\
América Latina y Caribe & 2,5 & 3 \\
América del Norte & 20,5 & 25 \\
Oceanía & 2,9 & 4 \\
Total & 80,0 & 100 \\
\hline
\end{tabular}

Fuente: OIT, 2004-11-24.

Los movimientos migratorios con motivo económico no afectan en exclusiva a los países desarrollados en calidad de receptores; precisamente como consecuencia del proceso de globalización, que implica nuevos países industriales y nuevos polos de desarrollo, se está produciendo un nuevo flujo migratorio hacia los países productores de petróleo y hacia los nuevos países industriales del pacífico asiático.

Esto quiere decir que Europa, Norteamérica y Australia han dejado de tener la exclusividad en la recepción de inmigrantes, compartiendo este hecho con los países de la península arábiga y algunos países de reciente industrialización, como China y Corea del Sur.

La fuerza de trabajo migrante engloba a personas con muy distintas calificaciones, desde profesionales y personal de dirección que se mueve en los mercados de trabajo internos de empresas transnacionales (sobre todo en países del norte), a un movimiento de especialistas y profesionales muy especializados en múltiples ocupaciones como ocurre en los ámbitos de las TIC, ${ }^{15}$ la medicina, ${ }^{16}$ enseñanza, ${ }^{17}$ navegación aérea y marítima, periodismo y comunicación y el mundo del espectáculo.

No obstante, los flujos actuales de migración siguen estando dominados por trabajadores que pasan a ocupar puestos poco cualificados en los segmentos del mercado de trabajo que han dejado vacantes trabajadores del país que se han trasladado a mejores puestos.

15 Un número importante de indios especialistas en software se han trasladado a Alemania.

16 Médicos y ATs españoles se han trasladado a Portugal.

17 Personas de países de la Commonwealth se trasladan al Reino Unido como enseñantes. 
Dentro de los trabajadores migrantes laborales, tenemos que señalar el incremento en el número de migrantes mujeres, por lo que se podría hablar de una feminización de los movimientos de población con respecto de épocas anteriores.

No hay que olvidar el aspecto económico que tiene para los países emisores las migraciones laborales; según indica S. Sassen (2002), los trabajadores migrantes envían a sus países de origen un volumen de remesas de más de 70.000 millones de dólares americanos.

Dentro de lo que denominamos trabajadores laborales migrantes, se distingue entre los permanentes, los temporales y los irregulares. Estos últimos son los que entran a trabajar en un país sin autorización legal, siendo el término "irregular» recomendado en Bangkok, en el Simposio Internacional sobre la Migración celebrado en 1999. Se estima que en Estados Unidos hay unos 8 millones de personas en esta situación y en lo que respecta a la Unión Europea, la EUROPOL informa que cada año ingresan en la Unión alrededor de medio millón de trabajadores indocumentados.

Estas migraciones irregulares no se limitan a los países desarrollados; por ejemplo, la orT estima que en la Argentina viven unos 800.000, procedentes de los países vecinos. La India cuenta con un gran número de personas de Nepal y de Bangla Desh, mientras que los afganos, después de los numerosos conflictos bélicos que han vivido en las últimas décadas, se han trasladado a Pakistán e Irán.

Las migraciones irregulares de trabajadores van destinadas tanto al mercado legal como al ilegal, como puede ser por ejemplo el trabajo sexual, y dan lugar a un tráfico de trabajadores que constituye una violación flagrante de los Derechos Humanos.

Traficar con emigrantes es un negocio lucrativo. Según datos de la ONU (Sassen 2002), en la década de los 90, las organizaciones dedicadas a este menester generaron ganancias de más de 3.500 millones de dólares americanos. Esta cifra no incluye a las mujeres destinadas a la industria del sexo y se calcula que en 1998 más de 4 millones de mujeres fueron objeto de este tráfico ilegal, produciendo unas jugosas ganancias a los traficantes.

La OIT recoge datos de los flujos de inmigrantes y emigrantes de algunos países del mundo. Si bien y como ya hemos indicado, actualmente hay cuatro zonas en el mundo que atraen migrantes laborales: Unión Europea, Norteamérica, Países productores de petróleo y nuevos países industriales de la cuenca del Pacífico. 
Las zonas de donde sale mayor número de migrantes laborales son los países de Europa del este junto con los países independizados de la antigua URSs, algunos países latinoamericanos como Ecuador, Colombia, México, Bolivia y Perú; países asiáticos como Filipinas, China, Indonesia y los países africanos del Mediterráneo.

Ahora bien, se observa que hay países que son a la vez receptores y emisores y por otra parte, al conocer el origen de los migrantes y su destino, es manifiesto que la gran mayoría de trabajadores circula por países cercanos, excepto los grandes polos de atracción como son Estados Unidos en América, Australia en Asia-Pacífico, la península Arábiga en Oriente-medio y la Unión Europea en Europa del este y el Mediterráneo.

\section{Refugiados}

Aunque cuando hablamos de movimientos de población siempre pensamos más en migraciones económicas, no podemos olvidar la existencia de otros movimientos de población que aunque siempre han existido, han incrementado su número en los últimos tiempos; nos referimos a los refugiados y desplazados que diferenciaremos en dos puntos distintos por cuestiones de definición conceptual, si bien ambos surgen en su gran mayoría como consecuencia de conflictos bélicos, religiosos o étnicos.

Los refugiados han dejado de ser una anécdota puntual para convertirse en un problema permanente y global, que aumenta al mismo ritmo que los nuevos conflictos, o «nuevas guerras» en palabras de Mary Kaldor (1999), se extienden por el planeta.

El siglo xx, quizá el más cruel de la historia (E. Hobsman, 1997), se inició con dos importantes acontecimientos que dieron lugar al surgimiento de los primeros intentos para delimitar este nuevo hecho: la Primera Guerra Mundial con la caída de los imperios en Europa y la Revolución Rusa de 1917. Con posterioridad a ésta es cuando se crea el Alto Comisionado para los Refugiados Rusos, en 1921, para dar cobijo a los exiliados de la Revolución de Octubre que salieron del país por no estar de acuerdo con las nuevas ideas revolucionarias y que fueron bien acogidos en Europa y Occidente en general.

La Segunda Guerra Mundial fue otro momento de importantes desplazamientos de refugiados hacia otros lugares: la diáspora judía, los republicanos españoles, los palestinos expulsados, los alemanes, etc. Se crea en 1947 la Organización Internacional de Refugiados y en 1951 el 
ACNUR $^{18}$ con la finalidad de dar acogida a quienes no pudieron volver a su país por miedo a la persecución política, ideológica, racial o religiosa y buscar soluciones a las situaciones que producían refugiados.

Se aprueba en Ginebra, en 1951, la Convención sobre el Estatuto de los Refugiados, de la que resultó un tratado internacional con carácter vinculante y en 1967, en la ONU, el Protocolo sobre el Estatuto de los Refugiados. ${ }^{19}$ La Convención y el Protocolo son los instrumentos internacionales fundamentales por los que se regula la conducta de los estados ante el problema universal de los refugiados al definir los derechos mínimos para el trato de los refugiados.

En la Convención se define como refugiado a:

Toda persona que debido a fundados temores de ser perseguida por motivos de raza, religión nacionalidad, pertenencia a determinado grupo social u opinión política, se encuentra fuera del país de su nacionalidad. ${ }^{20}$

En 2002, el número de personas bajo el amparo del ACNUR era de 20,6 millones, frente a los 19,8 millones del año anterior.

El ACNUR proporciona asistencia, además de a los refugiados, a los solicitantes de asilo, a los refugiados que han vuelto a sus hogares, a las comunidades locales que se ven directamente afectadas por los desplazamientos de refugiados, a las personas apátridas y a los desplazados internos.

El origen de las mayores poblaciones de refugiados en 2002 fueron Afganistán, Burundi, Sudán, Angola, Somalia, República Democrática del Congo, Irak, Bosnia-Herzegovina, Vietnam y Eritrea. En estos datos no se incluye a los 3,8 millones de palestinos que se encuentran bajo el mandato de protección de la agencia de las Naciones Unidas (UNRWA) para el socorro y reconstrucción de los refugiados palestinos en el cercano oriente.

Los principales países de acogida de refugiados son: Irán, Pakistán, Alemania, Tanzania, Estados Unidos, Serbia-Montenegro, República Democrática del Congo, Sudán, China y Armenia.

18 Alto Comisionado de las Naciones Unidas para los Refugiados.

19 Ratificado actualmente por 137 países.

20 La Organización para la Unidad Africana (OUA) introduce una extensión del concepto de refugiado, aplicándolo a quien, a causa de agresión externa, ocupación, dominio extranjero o grave perturbación del orden público en toda o una parte del país de origen o ciudadanía, se vea obligado a abandonar la residencia habitual para buscar refugio en otro lugar distinto al país de origen o ciudadanía (López Martínez, 2004). 
Cuadro 3.2. Distribución de los refugiados en el año 2002 por continentes

\begin{tabular}{lr}
\hline Asia & 9.378 .900 \\
África & 4.593 .200 \\
Europa & 4.403 .900 \\
América del Norte & 1.061 .200 \\
América Latina y Caribe & 1.050 .300 \\
Oceanía & 69.200 \\
Total & 20.556 .700 \\
\hline
\end{tabular}

Fuente: Los refugiados en cifras, 2003. ACNUR.

Cuadro 3.3. Evolución del número de refugiados en el mundo, 1980-2002

\begin{tabular}{lrrrrr}
\hline 1980 & 8.439 .000 & 1988 & 14.319 .000 & 1996 & 13.317 .400 \\
1981 & 9.696 .000 & 1989 & 14.706 .000 & 1997 & 11.966 .200 \\
1982 & 10.300 .000 & 1990 & 17.370 .000 & 1998 & 11.429 .700 \\
1983 & 10.602 .000 & 1991 & 16.829 .000 & 1999 & 11.625 .700 \\
1984 & 10.710 .000 & 1992 & 17.798 .500 & 2000 & 12.062 .500 \\
1985 & 11.844 .000 & 1993 & 16.280 .100 & 2001 & 12.029 .900 \\
1986 & 12.614 .000 & 1994 & 15.703 .100 & 2002 & 10.389 .600 \\
1987 & 13.103 .000 & 1995 & 14.860 .000 & & \\
\hline
\end{tabular}

Fuente: Los refugiados en cifras, 2003. ACNUR.

Algunos refugiados no pueden regresar a sus hogares por lo que el ACNUR les ayuda a encontrar un nuevo hogar, ya sea en el país de asilo donde viven o en terceros países donde pueden optar a su reasentamiento permanente. Los principales lugares de destino son Estados Unidos, Canadá, Noruega, Suecia, Nueva Zelanda, Dinamarca, Países Bajos e Irlanda.

\section{Desplazados internos}

El término fue acuñado a principios de los años 90 con el objetivo de nombrar de alguna manera el elevado número de personas que, víctimas de la violencia y de los conflictos étnicos, buscaban refugio dentro de las fronteras de sus propios países.

Las causas de este abandono de su residencia habitual podían deberse a los siguientes motivos: desastres naturales, diferencias religiosas o étnicas (in group o out group), persecuciones políticas basadas en cuestiones ideológicas y en aspectos económicos, o necesidad de buscar alimento o mejorar la calidad de vida.

Se considera que hay más de 25 millones de desplazados en el mundo distribuidos de la siguiente manera: 
Cuadro 3.4. Distribución de los desplazados en el mundo por países

\begin{tabular}{lrlr}
\hline Afganistán & 700.000 & Indonesia & 600.000 \\
Argelia & 200.000 & Irak & 1.100 .000 \\
Angola & 2.000 .000 & Israel & 250.000 \\
Armenia & 50.000 & Jordania & 800.000 \\
Azerbaiyán & 575.000 & Kenia & 230.000 \\
Bangladesh & 60.000 & Líbano & 300.000 \\
Birmania & 600.000 & Liberia & 150.000 \\
Bosnia-Herzegovina & 368.000 & Macedonia & 9.000 \\
Burundi & 400.000 & México & 12.000 \\
Chipre & 265.000 & Nepal & 100.000 \\
Colombia & 2.500 .000 & Nigeria & 50.000 \\
Congo (RDC) & 2.000 .000 & República Centroamericana & 10.000 \\
Congo-Brazzaville & 100.000 & Rusia & 371.000 \\
Corea del Norte & 100.000 & Salomón, Islas & 4.000 \\
Costa de Marfil & 700.000 & Senegal & 5.000 \\
Croacia & 17.000 & Siria & 170.000 \\
Eritrea & 75.000 & Somalia & 350.000 \\
Etiopía & 90.000 & Sri Lanka & 563.000 \\
Filipinas & 45.000 & Sudán & 4.000 .000 \\
Gaza & 26.000 & Turquía & 380.000 \\
Georgia & 262.000 & Uganda & 700.000 \\
Guinea & 20.000 & Yugoslavia & 262.000 \\
Haití & 6.000 & Zimbabwe & 200.000 \\
India & 600.000 & & \\
\hline
\end{tabular}

Fuente: us Committee for Refugees: World Refugee Survey, 2003. Washington.

El número de desplazados internos aumentó desde los inicios de la década de los noventa por lo que las Naciones Unidas decidieron tomar cartas en el asunto y elaboraron los Principios Rectores sobre el desplazamiento interno (Casals, 2004), aprobados en 1998 con el objetivo de paliar las consecuencias negativas que todo desplazamiento forzoso conlleva.

En el punto 2 de dichos Principios Rectores se da la siguiente definición de desplazados internos:

A los efectos de estos Principios, se entiende por desplazados internos las personas o grupos de personas que se han visto forzadas u obligadas a escapar o huir de su hogar o de su lugar de residencia habitual, en particular como resultado o para evitar los efectos de un conflicto armado, de situaciones de violencia generalizada, de violaciones de los derechos humanos o de catástrofes naturales o provocadas por el ser humano, y que no han cruzado una frontera estatal internacionalmente reconocida. 
Los Principios Rectores proponen la salvaguarda de los derechos individuales y sociales de los desplazados internos y la aplicación de las diversas leyes internacionales de Derechos Humanos a este colectivo para evitar la posible vulnerabilidad a que pueden ser sometidos en los nuevos asentamientos.

Las principales agencias y organismos implicados en favor de los desplazados son: ACNUR, PNUD, FAO, PMA, UNICEF, OMS, Alto Comisionado para los DDHH, Cruz Roja Internacional y Organización Internacional para las Migraciones.

Dentro del colectivo de los desplazados, las mujeres y los niños representan el 70\%, lo que supone unos 17/18 millones. Tenemos que pensar que son grupos vulnerables, susceptibles de abusos físicos, sexuales y psíquicos y que en la mayor parte de los casos no denuncian porque desconocen la existencia de las leyes para su defensa y son débiles, por lo que se enfrentan continuamente a situaciones de discriminación y de violación de derechos humanos.

\section{CONCLUSIONES}

En este breve repaso a los movimientos de población en la sociedad actual, que hemos denominado global por el incremento en el número de interrelaciones existentes, podemos constatar la ineludible conexión entre la sociedad predominante y los tipos de desplazamientos producidos en ella.

En un mundo cada vez más interconectado, los movimientos de población, sean por un motivo u otro, aumentan, convirtiéndose en algo central y característico de la presente sociedad global; la movilidad nos define como individuos y como sociedad. ${ }^{21}$

Los motivos a los que hemos aludido en las páginas anteriores se centran en cuestiones económicas y laborales vinculadas con los procesos de descentralización industrial y flexibilidad en los mercados laborales así como a los avances tecnológicos que permiten por una parte mayo-

${ }^{21}$ Creo que el spot publicitario de una compañía de telefonía móvil lo define a la perfección: «La vida es móvil». El libro de R. Sennett A corrosao do carácter, as consequências pessoais do trabalho no novo capitalismo, también se refiere a la movilidad exigida en la sociedad actual en lo que respecta a la movilidad laboral, familiar, ciudad e incluso identidad. 
res facilidades en los desplazamientos y por otra un desanclaje, en términos de Giddens (1993), un despegar las relaciones sociales de sus contextos locales de interacción y fomentar las relaciones entre los ausentes localizados a distancia de cualquier situación de interacción cara-a-cara. Esto se traduce en que los emigrantes siguen manteniendo con sus países de origen una relación que en épocas anteriores era mucho más difícil de tener.

Por otra parte, el final de la Guerra Fría no ha dado lugar a una paz mundial sino que, por el contrario, se está produciendo una serie de nuevos conflictos internacionales, «nuevas guerras» en palabras de Kaldor, que tienen lugar preferentemente en los denominados Estados colapsados o fallidos y que corresponden a un nuevo tipo de violencia organizada que implica a la sociedad civil y afecta a un número importante de personas no involucradas directamente en los conflictos.

De estos nuevos conflictos es de donde surgen los movimientos de población de refugiados y desplazados internos, también en aumento en los últimos años y aunque las organizaciones internacionales gubernamentales y no gubernamentales se ocupen de ellos no deja de ser un hecho que afecta a un número nada despreciable de personas que ven afectadas sus vidas cotidianas de forma brutal.

A un problema mundial, el crecimiento de los movimientos de población a los que nos hemos referido en los puntos previos, debería de buscarse soluciones y respuestas mundiales que cumplieran a la vez con el derecho humano fundamental de la libertad de movimientos ${ }^{22}$ y con las condiciones adecuadas en el lugar al que se trasladen, según apuntan las distintas convenciones y pactos internacionales, a la vez que eliminar todos los movimientos forzados, nuevas formas de esclavitud, con fines laborales fundamentalmente, que violan flagrantemente los mínimos derechos humanos de libertad y dignidad.

La expansión capitalista, las brechas demográficas entre el norte y el sur (también ahora el este) y las «nuevas guerras» son motivos suficientemente importantes como para plantear un debate internacional que permitiera cumplir por una parte con el derecho al movimiento libremente elegido y por otra rechazar tajantemente el movimiento forzado u obligado por las circunstancias.

22 Artículo 13 de la Declaración Universal de Derechos Humanos. 


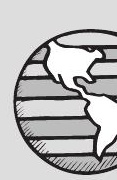

4 .

Aproximación teórica a los conceptos de identidad y estereotipos

en una sociedad intercultural

ENRIC RAMIRO ROCA 
«Si hablas una lengua indígena, eres un indio y, por tanto, eres tonto. Pero los indígenas no somos tontos, sabemos pensar muy bien y lo hemos demostrado».

Dolores Villalobos Cuamatzi. Consejo Indígena Popular de Oaxaca Ricardo Flores Magón, México.

http://www.eladelanto.com/noticias/noticia.asp?pkid $=125975$

\section{INTRODUCCIÓN}

En los inicios del siglo xxI estamos asistiendo en el mundo occidental y con más intensidad en nuestro país y en el Estado español en general, a una eclosión migratoria. Nuestra península, que ha sido siempre una zona eminentemente de salida de población, durante las últimas décadas ha pasado a recibir a millones de personas. Pero esta dinámica no es extraña a lo largo de la historia cuando la inexistencia de fronteras en un principio y la permeabilidad posterior favorecían el cambio de residencia sin más problemas. Durante miles de años, los habitantes de este planeta han vivido en las zonas geográficas que han deseado y se han adaptado a la zona de destino al tiempo que influían en ella. La mezcla intercultural ha sido un fenómeno cotidiano hasta que poco a poco las diferentes sociedades y grupos han ido sedimentando y normalizando sus usos y costumbres, imponiendo unos límites, unos impuestos y unas dependencias. El progresivo cambio del nomadismo al sedentarismo, así como el paso de la tribu a la nación, o al estado-nación en muchas ocasiones de forma impuesta, ha ido conformando el mundo como un puzzle cada vez más dependiente, dando paso a una globalización que iba cerrando las puertas a las decisiones intraterritoriales y abriendo el paso a las voluntades extraterritoriales.

En este panorama actual, la identidad y los tópicos y estereotipos cobran una gran importancia porque representan el concepto oculto que 
Figura 4.1. Cartel de Manos Unidas

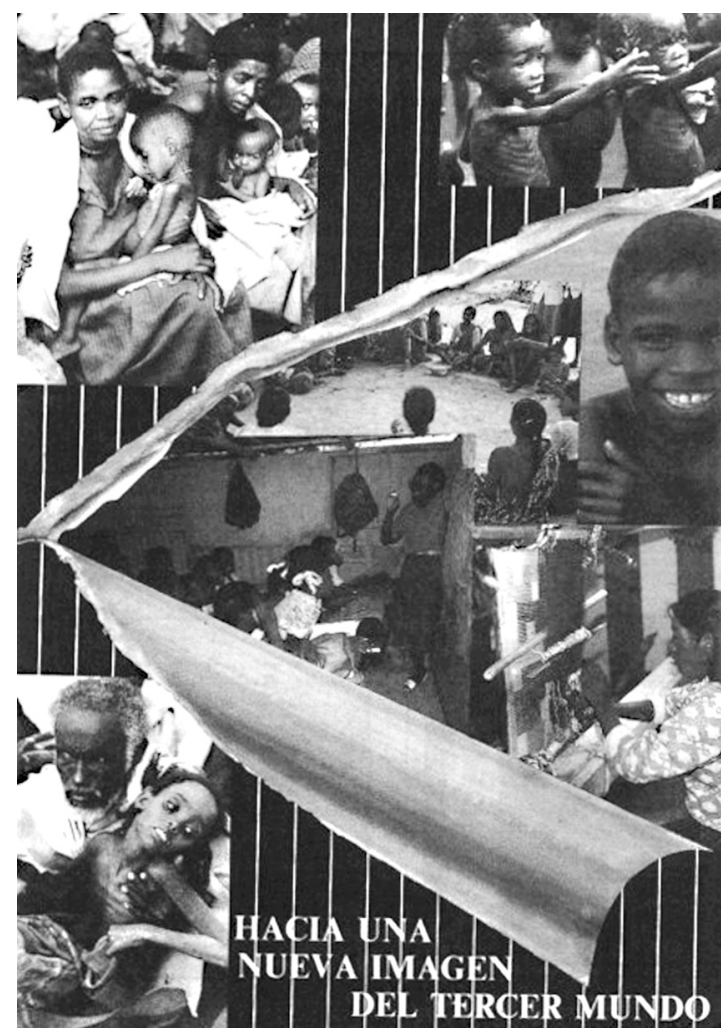

Fuente: Manos Unidas en www.fuhem.es/cip/educa/ayu10.htm

provoca determinadas acciones por parte de algunos colectivos que en ocasiones son malinterpretadas, ignoradas o aplaudidas por el resto de la sociedad sin tener demasiado clara su justificación o una simple explicación. La problemática de la incomprensión de muchos latinoamericanos o castellanohablantes en general cuando se enfrentan sorprendidos a la riqueza lingüística de las comunidades con lengua propia o a las reivindicaciones lingüísticas de sus habitantes son un buen ejemplo. Otro podría ser la reacción desde el concepto de un país centralizado frente las tendencias secesionistas o el derecho al autogobierno, e incluso la simple convivencia con culturas y etnias diferentes a la propia, son otras ejemplificaciones que ilustran la situación actual. Expresiones como «ir como un gitano", "una faena de moros», «más tonto que un indio» o "trabajar más que un negro» son tan sólo algunas de las frases menos xenófobas 
con que nos podemos encontrar de forma cotidiana en nuestra sociedad. Por tanto, vamos a centrarnos en el concepto de identidad y arraigo a un lugar por un lado y en la dinámica de los estereotipos por otro, con el objetivo de marcar hitos imprescindibles para comprender el fenómeno de la interculturalidad y aminorar los posibles conflictos que se puedan producir en la necesaria convivencia entre individuos.

\section{GRUPOS ÉTNICOS Y ARRAIGO EN UN LUGAR: LOS ESTEREOTIPOS}

En el pequeño universo de cada persona, los lugares son alguna cosa más que unas simples entidades geográficas que proporcionan el escenario físico donde se desarrolla la vida. La mayoría son centros de experiencias cargados de una gran significación, unidos al núcleo de la existencia humana como un conjunto de depósitos llenos de vivencias que se encuentran en el centro de la identidad y del bienestar psicológico del individuo. Desde esta perspectiva, los lugares serían «centros de significados» o intenciones, entendidos como entidades que encarnan la experiencia y las aspiraciones de la gente (Godkin, 1985). Esta ha sido tradicionalmente la interpretación sobre la importancia del territorio vivido desde los años 70 (Tuan, 1971: 281; Relph, 1976: 55) y gran parte de estos estudios se han centrado en lugares donde los símbolos eran comunes y compartidos por un determinado grupo de personas: la plaza Roja de Moscú, la torre Eiffel, las cataratas del Niágara, la estatua de la Libertad, la Acrópolis de Atenas, la tumba del profeta Alí, la Kashba, o las Pirámides son hitos nacionales de experiencia común que fomentan la unidad y el orgullo patriótico. En muchos países y a escala más local, la tienda de la esquina, determinado restaurante o el local de la asociación son símbolos importantes de vecindad e identidad comunitaria.

Algunos investigadores se han referido a la existencia de lugares universales que traspasan la identidad social o política de un grupo, mientras otros aseveran la importancia de lugares imaginados caracterizados por los cuatro elementos: aire, fuego, agua y tierra. Así, por ejemplo, la imagen de la montaña evocaría la sensación de poder, mientras que la del fuego sugeriría una sensación de parálisis. De la misma forma que se personifican experiencias comunes, los lugares pueden tener para las personas unos significados únicos. De hecho, la conexión al lugar ha estado considerada en los tratados de psiquiatría como un hecho significativo en el desarrollo de 
la identidad personal desde hace años (Searles, 1960; Wenkart, 1961). Sin embargo poco se sabe sobre los mecanismos y los procesos por los cuales las imágenes del lugar entran a formar parte de la concepción que cada uno tiene de sí mismo.

Lo que parece demostrado es que las experiencias que mantienen un sentido y una coherencia en sí mismas, son "captadas" y retenidas en la memoria parcialmente como una imagen del lugar donde ocurrieron originalmente. Es decir, que la sensación de autoidentidad se incorpora en parte al ser de la persona cuando va ligada al lugar donde aquella fue experimentada. Por el contrario, los lugares no "arraigados» se olvidan rápidamente. Este panorama nos permite afirmar que el entorno físico es un componente integral en las experiencias y sentimientos de bienestar, y la construcción de un entorno que sea simbólicamente familiar provoca una sensación de continuidad y estima. Por lo tanto, sería conveniente que todas aquellas personas implicadas en la construcción del medio que habitamos (arquitectos, políticos, jardineros, educadores, geógrafos, psicólogos...) procuraran dirigir sus esfuerzos hacia al diseño y realización de entornos humanos que dieran apoyo a aquellas experiencias que favorecieran la sensación de bienestar.

La oposición entre globalización e identidad está dando forma a nuestro mundo y a nuestras vidas: la sociedad-red que se difunde por todos los sitios, sacudiendo las instituciones, culturas y economía. Junto a la revolución tecnológica y a la transformación del capitalismo, hay unas vigorosas expresiones de identidad colectiva. Entre ambos conceptos, globalización y nacionalismo, se encuentra el estado-nación arrastrando en su crisis a la noción misma de democracia política y perdiendo cada vez más competencias y razón de ser a favor de áreas mucho más amplias como la Unión Europea. De hecho, los seres humanos se encuentran divididos en una serie de colectivos que comparten una cierta homogeneidad territorial, cultural, de lengua, ... y un sentimiento de pertenencia común. Estos "pueblos» han 1legado a distintos grados de organización política, unos al de Estado-nación por medios pacíficos o no e incluso están inmersos en realidades supranacionales; y otros están subyugados política y administrativamente y continúan reivindicando su identidad. En cualquier caso, independientemente de su status, aquello que nos permite hablar de "pueblos» son dos elementos (Javaloy, Bechini y Cornejo, 1990): el sentimiento de pertenencia a un grupo, más o menos subjetivo, y algún tipo de semejanza objetiva basada en costumbres, idioma, pasado común, territorio compartido... 
Bajo esta concepción, podemos llamar "grupos étnicos» a los colectivos bereberes, quechuas, aymaras, mapuches, vascos, tamiles, tibetanos... pues, por una parte, ellos se consideran así (Javaloy, Bechini y Cornejo, 1990) y por otra, también les consideran los habitantes del estado, aun reconociendo que esta agrupación no es uniforme, y hay casos más sentidos y consentidos que otros. Sin embargo, la existencia misma de estos colectivos étnicos genera inevitablemente una variada gama de relaciones entre sí, tanto en sentido vertical como horizontal. Y en este contexto de factores, adquiere una importancia singular la percepción que estos grupos tienen de sí mismos y de los otros grupos, resultado en la mayoría de las veces de un conglomerado de actitudes, estereotipos, imágenes... tanto de los espacios geográficos como de sus habitantes. Esta situación va impregnada muy a menudo de elementos afectivos o emocionales, cargados de antipatía o simpatía y que generan sentimientos de aproximación (actualmente Irán-Irak) o de rechazo (por ejemplo entre Bolivia y Chile).

La tesis del posmodernismo es que al haber surgido las naciones en la era moderna, sus productos como el nacionalismo o la identidad nacional pertenecen al mundo en declive de la modernidad. La existencia de naciones y estados implica un mundo de fronteras, de diferenciación y de fragmentación, totalmente contrapuesto a un mundo que avanza hacia nuevos modelos de identidad. Para el posmodernismo se camina hacia una cultura global, sin puntos fijas ni verdades uniformes, sino con una multiplicidad de voces donde todo se globaliza, incluido el individuo, y donde la misma existencia de estados está amenazada por la presión de las organizaciones supranacionales y las fuerzas multinacionales. Una tendencia que globaliza la economía pero no las soluciones sociales de los problemas.

No obstante, como resultado de esta nueva etapa, se genera una situación paradójica para el individuo: al perder las fronteras, se pierde también el sentido de lugar y la identificación con el territorio se diluye, de forma que afecta también a su propia identidad personal. Nos encontramos ante una persona que podríamos definir como un «yo saturado» (Gergen: 1992) de información y de relaciones, un hombre cosmopolita que habita en un mundo electrónico y global más que en una tierra o país concreto. La identidad deviene un conjunto y el individuo se puede volver fragmentado y disperso y puede acabar siendo extranjero para nosotros mismos (Kristeva, 1991).

Para intentar superar este sentimiento de inseguridad, muchas personas recorren a nuevas formas de identificación con otros símbolos, ideas, 
líderes,... ante el vacío identificador de las sociedades tradicionales. Esa incapacidad de vivir en realidades ambiguas, sin certezas sólidas, provoca la adopción de verdades fijas, tendiendo a dividir el mundo en categorías rígidas: nosotros-ellos, creyentes-no creyentes, patria-extranjeros, criollosindígenas... El resultado final es la aparición de nuevos movimientos o sectas que con esa búsqueda de identidades, vuelven a fragmentar el entorno social. De forma similar pasa con los estados, ya que amenazados desde arriba por la globalización, acaban también presionados desde abajo por los movimientos locales que reivindican nuevas identidades.

Frente a esta realidad compleja, las personas la intentan simplificar mediante la adopción de estereotipos. Podríamos definir estereotipo como una «imagen convencional que se ha acuñado para un grupo de gente» (Quin y McMahon, 1997: 137); se trata por lo tanto de una forma simple de pensar sobre un conjunto de personas que facilita el comunicar nuestras ideas, y nuestra mente los utiliza con frecuencia y de forma inconsciente. A veces se ha formado a partir de nuestras vivencias e interrelaciones con ese colectivo y en caso de no tener un contacto personal, normalmente se tiende a crearlo a partir de los medios de comunicación. En definitiva es una forma sencilla de clasificar a la gente basada en varios factores, resultado de una selección de características para representar a un determinado grupo, una elección que dependerá de los valores que tiene sobre él la comunidad, es decir, de la opinión sobre el grupo.

Por lo tanto, el estereotipo es una forma de representar grupos de gente. Cualquier grupo es una mezcla compleja y, sin embargo, los estereotipos parecen simples y sin complicaciones porque ofrecen una descripción altamente selectiva de un colectivo. En realidad proporcionan un ahorro mental porque son fáciles de usar y entender y los utilizamos para organizar nuestra forma de pensar. Al ponerlos en funcionamiento, emitimos juicios sobre los otros grupos sociales al tiempo que los compartimos, de forma que acaban pareciendo naturales. Hay estereotipos sobre razas y etnias, pero también sobre religiones, países, zonas geográficas, según el género, la edad, las costumbres o simplemente situaciones concretas como el divorcio.

En nuestro caso podemos investigar sobre la opinión de un conjunto de personas con respecto a otro, en el que la mayoría utiliza unas determinadas imágenes en su comunicación porque todos o casi todos los conocen. El hecho de que los estereotipos representan creencias inconscientemente compartidas es determinante para ocultar los juicios de valor que 
se esconden detrás de cada estereotipo. Así se convierten en la forma lógica y normal de pensar, de hablar y de hacer chistes a propósito de un grupo y se utilizan tanto en nuestra vida diaria que podemos llegar a pensar que son «lo más natural del mundo" aunque sean tan sólo una representación del grupo. Sin embargo, no existen imágenes de todos los grupos sociales ni tienen tampoco todos la misma fuerza; incluso existen estereotipos múltiples y algunas veces incluso contradictorios, pero ninguno de ellos es invariable o eterno.

Sin embargo, ¿quien crea los estereotipos? Hay varios elementos que contribuyen a su diseño. Indirectamente somos todos nosotros los que los construimos, y de forma directa la medios de comunicación como el principal factor. Igualmente no se crean sobre todos los grupos de personas, sino principalmente en aquellos colectivos que se consideran un problema, una molestia o una amenaza; aunque también hay estereotipos positivos. Tampoco todas las personas tienen los mismos ni con el mismo valor, ni permanecen inalterables a través de la historia, pero una vez creados es muy fácil mantenerlos y muy difícil cambiarlos.

Tenemos ejemplos en la relación entre Bolivia y Chile tras la guerra que provocó la pérdida de la salida al mar de la primera nación, el tema de la emigración mexicana hacia EeuU ("camisas mojadas») o la visión sobre los indígenas por parte de la mayoría de las clases dirigentes iberoamericanas, por ejemplo. También hay comunidades con una imagen muy definida y otras con una muy difundida; o algunas pasan desapercibidas, prácticamente inexistentes, y en cambio otras son renombradas por una inmensa mayoría. Si preguntáramos a un grupo de adolescentes americanos que nos enumeraran una lista de países del continente, a buen seguro que habría algunos muy repetidos por casi todos y otros con índices de presencialidad anecdótica. Las diferencias sobre los estereotipos obedecen a múltiples razones: a veces son geográficas (no opinan igual sobre los mexicanos o sobre los afroamericanos, los estadounidenses del norte que los del sur), según el tipo de centro escolar si está subvencionado con fondos públicos o no, por la población de la localidad donde viven o según el grado de nacionalismo en el que se posicionan (por ejemplo en Canadá) entre otros.

También pueden crearse los estereotipos por una supuesta amenaza en la subsistencia y estabilidad de la comunidad como en el caso de los judíos durante la Segunda Guerra Mundial o la disyuntiva comunistas-capitalistas en el período de la Guerra Fría. Pero más sutil que la violencia física es 
la amenaza de la posición privilegiada donde se pueden perder más derechos, más libertad o más control sobre las decisiones del poder, y este es el problema de las mujeres en general con respecto al género masculino. Otros grupos son percibidos porque su estilo de vida no es como el del grupo dominante, que es el que se considera «normal» y "correcto». Estaríamos ante el caso de gitanos, asiáticos o africanos, de los cuales la sociedad occidental elige aquellas señas más destacadas o negativas, dejando totalmente en el olvido las positivas. Y en todos los casos, la mayor parte de las veces no se crean los estereotipos de una manera consciente, sino que suelen surgir lenta y sutilmente. En general, todos ellos reflejan las posiciones relativas de poder de los grupos competitivos dentro de la sociedad y justifican la importancia de los grupos dominantes.

Como norma, el origen de los estereotipos está asociado a un problema que puede tener características muy diferentes: indígenas, negros, mujeres, inmigrantes, musulmanes, homosexuales, masones, ... son rechazados en ocasiones por el poder, que ve amenazada su estabilidad. Y a medida que el tiempo pasa y ciertas prácticas culturales o sociales se asocian a los estereotipos, estas parecen ser también «naturales» desde una visión diacrónica. Pero todos los problemas tienen causas y efectos: si una persona no estudia tiene más probabilidades de suspender, si uno no respeta las señales de tráfico puede tener un accidente más fácilmente, o si uno fuma y bebe, generalmente tendrá más enfermedades que una persona que lleva una vida sana. Pero en el caso de los estereotipos, normalmente causa y efecto están invertidos con la finalidad de evitar el problema. Por ejemplo, a los jóvenes generalmente les cuesta encontrar su primer trabajo, por lo tanto no tienen dinero y tienen mucho tiempo libre. Además, la sociedad de consumo «los obliga» a llevar un ritmo de vida concreto. La causa es que se hacen notar más en los lugares de ocio, o por las calles si no suelen gastarse el poco dinero que tienen. Pero el estereotipo se invierte: como están por las calles y por los lugares de ocio es gente que no quiere hacer nada sino vivir de los padres. Esta es una forma que tiene la sociedad, y más concretamente los grupos de poder, para justificar muchas de sus acciones, creencias y valores y mostrar a los otros que determinados grupos «están fuera de juego».

Por lo tanto, podemos concluir que los estereotipos son un medio para justificar una actitud negativa hacia un grupo de gente, y que se puede construir seleccionando unas cuantas características negativas del colectivo y olvidando las positivas, o bien invirtiendo causa y efecto con el obje- 
tivo de desviar la culpabilidad. Pero incluso sabiendo que esta situación es injusta se continúan utilizando los tópicos porque han ido instalándose de una forma natural y lenta en nuestros pensamientos, de forma que acaban en la lógica del subconsciente. Es más, en todos los estereotipos hay elementos de verdad aunque muchas veces distorsionados. Es nuestra capacidad de observación la que nos hace ver a veces casos aislados que verifican esta imagen, contribuyendo a extender este juicio de valor a todos los miembros de ese grupo. En tercer lugar, nos conviene emplear estereotipos porque nos acerca a los valores del grupo de poder, con la ideología de los grupos dominantes, los cuales hacen ver que esa imagen la tiene mucha gente, y la mayoría no puede estar equivocada, con las víctimas de los estereotipos. Y por último, la cuarta razón es que nos evitan el esfuerzo de tener que pensar de una forma compleja, pues son simples, rápidamente se conocen y significan más o menos lo mismo para todos.

Figura 4.2. La elaboración de los estereotipos
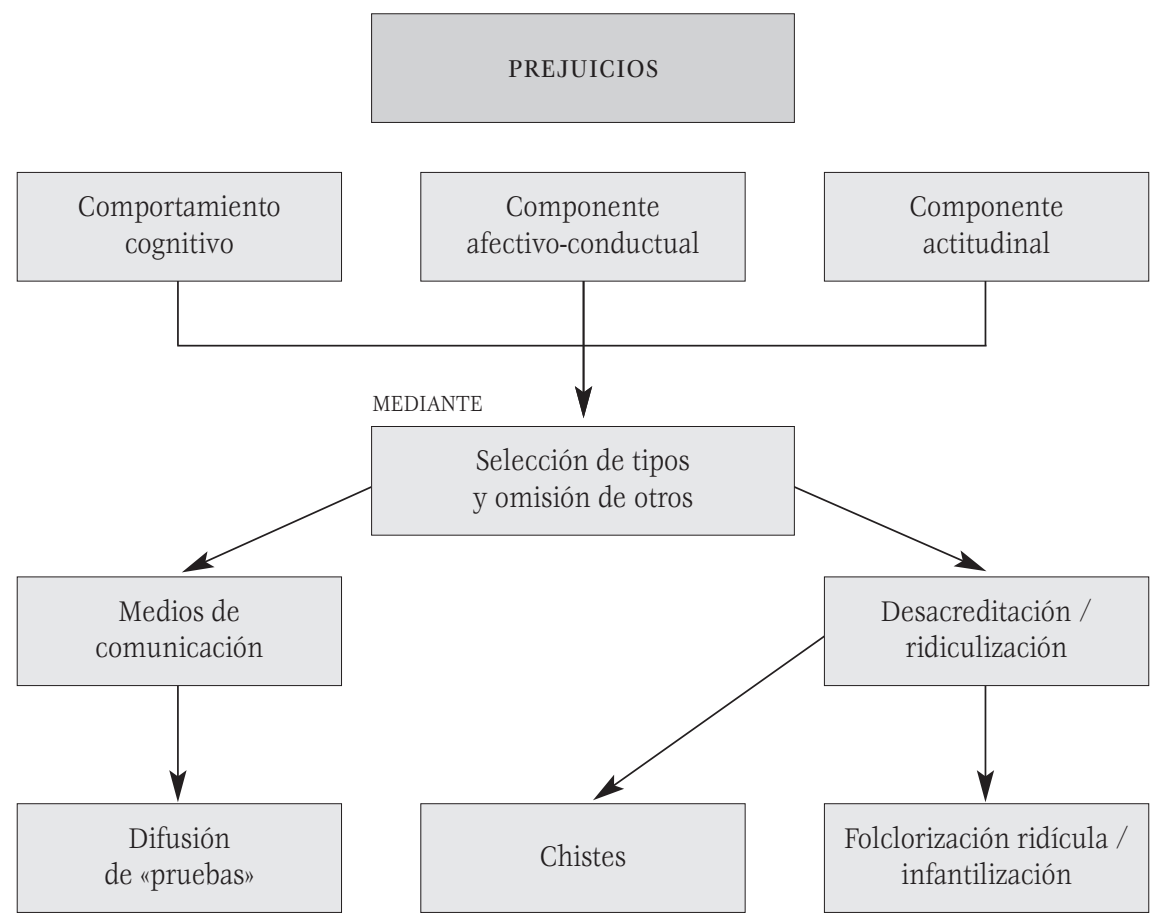

Fuente: Xavier Lluch (CEP Valencia). 


\section{LOS MEDIOS DE COMUNICACIÓN Y LA NECESIDAD DE ANALIZAR LOS ESTEREOTIPOS}

Los medios de comunicación (MMCC) son el factor clave en la creación de los estereotipos. Su funcionamiento y estructura hacen que necesiten audiencias masivas, lo cual obliga a los «creadores» de tópicos a la búsqueda de personajes y situaciones que se reconozcan fácilmente, y que puedan ser comprendidas y asumidas por cualquiera. Por eso, en series y programas de televisión, los estereotipos se pueden reconocer en seguida, los símbolos se registran conscientemente y los valores afectan de forma inconsciente. De hecho, parte de la «diversión» tiene su origen al prever las reacciones de los actores y actrices que utilizan los estereotipos en la codificación y en la interpretación de la información. Debemos tener en cuenta que aparecen los mismos en la televisión, periódicos y revistas, radio, webs, literatura... como consecuencia de la concentración de los medios y que las imágenes distorsionadas y los valores que comportan tendemos a identificarlos como ciertos por la razón de estar generalizados entre los MMcc.

Algunos medios están limitados en la utilización de argumentos y personajes como es el caso de los cómics y por lo tanto «están más obligados» a su utilización que cuando el medio ofrece un amplio abanico de posibilidades como es el caso específico de una novela. Otros medios tienen grandes mercados de demanda, como es el caso de las televisiones, y su necesidad es llenar las numerosas horas de programación. Eso obliga a tener muy en cuenta los gustos, intereses y valores comunes del público teleadicto, pues su objetivo es minimizar los costes y obtener los máximos beneficios, de forma que sus personajes deben de ser muy claros y que se puedan identificar de forma sencilla, aunque suponen juicios de valor sobre el grupo por parte de la caricatura mostrada. Esta necesidad hace que se deban grabar multitud de horas de imágenes que deben ser «engu1lidas» por el público, de forma que no tienen más remedio que utilizar de forma abundante los estereotipos para que puedan ser ingeridos por los telespectadores.

En conclusión, los estereotipos son unas imágenes que la sociedad actual va incrementando y que por lo tanto no podemos ignorar ni huir de ellos, sino que lo que hay que hacer es aprender a identificarlos como juicios simplistas de valores sobre unos determinados grupos. La consecuencia más extrema es marcar a un colectivo para convertirlo en un gru- 
po tan diferente que sus miembros se convierten en proscritos de su propia sociedad. Nos estamos refiriendo a grupos con comportamientos sexuales distintos a la mayoría, por el color de la piel, la vestimenta, la forma del pelo y a aquellos con culturas diferentes, pero también pueden haber colectivos perseguidos por determinados sectores de población en épocas recientes como es el caso de los indígenas.

No es que vivamos en una sociedad depravada que disfruta atacando a los grupos inferiores hasta convertirlos en estereotipos (Quin i McMahon, 1997), sino que nuestros valores y actitudes son absorbidos y reflejados sin reflexionar de forma suficiente. Frente a este proceso inconsciente, únicamente podemos utilizar dos vías: el pensamiento crítico y el conocimiento real del grupo estereotipado. Por eso es tan importante analizarlos, sacarlos a la luz pública y ser conscientes de ellos como un primer paso.

Posteriormente habrá que diseñar alternativas concretas por parte de todos aquellos colectivos interesados en cambiar las imágenes que se producen aportando una infraestructura que lo haga posible. En caso contrario, todo quedará en estudios y literatura pedagógica o idealista que tendrá como consecuencia la frustración de aquellas personas interesadas y convencidas del cambio pero a las que no se han dado los recursos adecuados para las modificaciones.

Pero también hay signos positivos. Algunos grupos han logrado que ciertos sectores de la sociedad sean conscientes de los juicios de valor injustos como es el caso de la mujer en muchos países, mientras otros como los gitanos, marroquíes o sudamericanos aún continúan sufriendo los tópicos negativos en la mayoría de los países del mundo. Sin embargo, los estereotipos llamados «positivos» para la sociedad y que son aque1los donde los grupos de poder han dado su visto bueno, no significan que realmente sean buenos sino que están aceptados por aquellos que dominan la sociedad, aunque su imagen continúa teniendo una función diferenciadora entre «ellos y nosotros».

A lo largo de décadas, los estereotipos han experimentado algunos cambios e incluso algunos han dejado de tener vigencia según sectores de población y países, pero su cambio lento hace que se adapten fácilmente a las circunstancias. Además, los mismos medios de comunicación los refuerzan al pedir a los personajes famosos que utilicen elementos de la imagen estereotipada porque atrae a la audiencia, es popular, y por lo tanto, proporciona beneficios económicos. 
Cuadro 4.1. Ejemplificación de la dinámica de los estereotipos: el caso de los indígenas

ESTEREOTIPOS

1. Nobles y salvajes

MD Imágenes infantilizadas

Medios de comunicación

Is Religión como instrumento de dominación

Competencia por la tierra

CA No hay hostilidad inicial de los aborígenes cuando llegan los europeos

Hay enfrentamiento físico cuando comienza la lucha por la tierra

\section{Violentos (miserables, infrahumanos)}

MD Medios de comunicación: publicitan «casos». Estos actúan como difusión de «pruebas»

Is Hay justificación por tratarlos con dureza a la hora de desposeerlos de la tierra

\section{Gandules. No cultivan la tierra}

MD Medios de comunicación

Difusión de "pruebas"

Is Desposeimiento de la tierra (no merecen inversiones, ya que no van a trabajar...)

CA El sistema de explotación intensivo de los europeos choca con el autóctono

\section{Infantiles y primitivos. Necesitan ser educados}

MD Medios de comunicación:

- Chistes de infantilismo e incapacidad

- Folclorización ridícula

Difusión de "pruebas»

Is Desposeimiento de la tierra (necesitan ser tutorizados. Los europeos

deben ser los gestores, ellos son incapaces...)

5. Borrachos, irresponsables, inferiores...

MD Medios de comunicación:

- Chistes de infantilismo e incapacidad

- Folclorización ridícula

Difusión de «pruebas»

Is Desposeimiento de la tierra (no merecen dinero público, no son capaces

de rentabilizarlos, gestionarlos...)

CA Los europeos llevan el alcohol

Durante mucho tiempo prohỉben beber a los aborígenes

\section{Personas ávidas de dinero}

Is Disminución en la inversión de dinero público

Freno político a las reclamaciones crecientes de los colectivos aborígenes concienciados

CA En los años 60, reclamación de las comunidades aborígenes de sus derechos

Se actualiza el estereotipo: de salvaje a violento, gandul, infantil, irresponsable, aprovechado

MD: medio por difundirlo; Is: intereses subyacentes; CA: contraargumentos.

Fuente: Basado en Quin i McMhon (1997). 
En resumen, podemos definir a los estereotipos (Colectivo Amani, 1994) como aquellos rasgos que se atribuyen a un grupo, la imagen mental simplificada que tenemos de ellos o las creencias por las que se atribuyen determinadas peculiaridades.

Los tópicos tienen las siguientes características: son compartidos por mucha gente, se otorgan a una persona por ser miembro de un grupo, son muy resistentes al cambio, simplifican la realidad, orientan y completan las expectativas, se recuerdan con mucha facilidad y cualquier información por mínima que sea los corrobora fácilmente. Paralelamente, los prejuicios contienen elementos de emoción y de acción, de forma que los podríamos definir como un juicio previo no comprobado, favorecedor o no, alrededor de una persona o un grupo en un sentido coherente. Muy ligado a este concepto está el de discriminación, que hace ya referencia a un comportamiento de prejuicios negativos o animadversión hacia otras personas.

Estas percepciones pueden partir del individuo y de la sociedad al mismo tiempo. Su origen radica en la necesidad de simplificar la realidad como organizadores de la información, al tiempo que marcan las diferencias y son generadores de conductas específicas. Sus características más concretas las podríamos resumir en la gran capacidad de resistencia que tienen, a pesar de que nuevas informaciones o imágenes vayan en contra de las ideas previas, y el efecto de autocumplimiento, el cual nos hace ver que estos grupos actúan muchas veces según nuestras perspectivas y no por aquello que realmente hacen. Asimismo, otro mecanismo ayuda a afianzar los anteriores, como es la tendencia a recordar mejor aquello que es coherente con lo que pensamos y asombrosamente también lo es en el caso contrario, sin que signifique ninguna modificación.

De esta forma, si hemos llegado o nos han hecho llegar a pensar que los habitantes de una determinada región o país son de una forma de ser «X», difícilmente se podrá cambiar a menos que utilicemos todos los medios necesarios y con una claridad de objetivos. Si el estereotipo continúa justificando las actitudes existentes, estas no cambiarán, y los grupos que fueron juzgados en el pasado de forma negativa continuarán sintiendo y padeciendo las consecuencias. A veces se utiliza el peligro externo o la maldad de otros como chivo expiatorio de la propia incapacidad del grupo dominante para lograr avances en la comunidad; es un autoodio reflejado en otros para justificar incapacidades. Y un elemento transmisor son los chistes racistas y xenófobos que muy sutilmente transmiten la forma oficial de discriminación. 
En este sentido, son la familia, la escuela, los gobernantes y los medios de comunicación principalmente los responsables de su modificación en un sentido $u$ otro.

De todas formas, un paso previo muy importante, es la necesidad de conocer los valores que hay detrás de los estereotipos con el fin de poderlos desmontar más fácilmente. Todas y todos tenemos parte de responsabilidad en este tema y nuestra actuación debe ser continua y cotidiana. 


\title{
5 .
}

\section{La immigració actual a Espanya. Aspectes demogràfics*}

\author{
ANDREU DOMINGO I VALLS
}

* Aquest treball ha de considerar-se producte del projecte Procesos migratorios, asentamiento y estructuras familiares: un estudio sociodemográfico (BSO2001-1233) subvencionat pel Pla Nacional I + D del Ministerio de Ciencia y Tecnologia. 
INTRODUCCIÓ. EL BOOM IMMIGRATORI DEL SEGLE XXI

La immigració internacional a Espanya durant la dècada dels noranta, ha experimentat, fins i tot més acusadament que altres països, l'acceleració, la diversificació - tant en els orígens com en d'altres característiques sociodemogràfiques dels migrants-, i el notable augment de la irregularitat, que alguns autors han assenyalat constituien les principals característiques de l'evolució recent per al conjunt de la Unió Europea (Salt i altres, 2000; Sopemi, 2001). Si a 1990 es comptabilitzaven 407.647 permisos de residència, 13 anys més tard, la xifra s'havia quadruplicat arribant al 1.646.011 permisos en vigor a 31 de desembre de 2003, aquest altíssim increment queda encara disminuït en comparació amb les xifres del Padró continu, on per 1'1 de gener de 2003, els empadronats de nacionalitat estrangera ja arribaven a les 2.664 .168 persones. Si la dècada dels vuitanta va representar per Espanya la mutació d'un país històricament emigratori en un d'immigratori (Muñoz Pérez i Izquierdo, 1989), la dels noranta consolida aquest canvi i situa Espanya al voltant del 5\% que assoleix la mitjana de la Unió Europea amb un 3\% de la seva població total amb nacionalitat estrangera segons els permisos o un $6 \%$ amb dades padronals.

Aquesta trepidant evolució, s'ha vist a més acompanyada d'importants transformacions en la legislació i en els criteris i cobertura dels recomptes estadístics, que han determinat la visibilitat estadística de la migració internacional i de la població estrangera resultant. De la frenètica activitat legislativa desplegada durant aquest període, que paradoxalment s'ha acompanyat d'un progressiu augment de la irregularitat, podem destacar les següents mesures: Reforma del Codi civil en l'accés a la nacionalitat espanyola (Ley 18/1990), 3 regularitzacions extraordinàries (1991, 2000 i 2001), l'inici d'una política de contingents l'any 1993, el 1996 la Reforma del Reglamento de la Ley de Extranjería de 1985, l'aprovació d'una nova Ley de Extranjería l'any 2000 (Lo 4/2000), i la reforma d'aquesta mateixa Llei també 
l'any 2000 (LO 8/2000). Per fi, quant als canvis en els criteris estadístics, la coincidència de diferents fonts amb una mateixa data de referència, com per l'any 2001, el Cens de Població i Habitatge, el Padró continu de Població i els permisos de residència, posen de manifest el decalatge entre unes i altres fonts estadístiques.

En aquests moments una de les preguntes més peremptòries és saber si aquest excepcional creixement s'ha de considerar un salt qualitatiu que ha tocat sostre, un boom immigratori producte de l'agregació de diferents factors actuant en una mateixa direcció (legislatius, econòmics, demogràfics), o si pel contrari s'ha de prendre com la constatació d'una tendència que a principis de la dècada només ens atreviem a qualificar d'emergent, sense sospitar el volum que podia adquirir i la rapidesa amb la que es produiria.

En aquest segon cas, com provaré d'argumentar, un cop més l'evolució demogràfica d'Espanya, apareixeria com a tardana respecte a d'altres països europeus però anunciaria una inusitada intensitat en els propers fluxos internacionals que podria portar-la a valors màxims de població estrangera resident en relació al conjunt de la Unió Europea, ara representats per estats com Bèlgica o Àustria que arribaven l'any 2000 al 9\%.

\section{L'ESTRANGER EN EL LABERINT ESTADÍSTIC I LEGISLATIU ESPANYOL}

Des de l'aprovació l'any 1985 de la Llei d'Estrangeria i del seu reglament en 1986, com a requisit per l'entrada d'Espanya a la Unió Europea, la legislació que estableix els drets i els deures dels estrangers, i les accions que haurien de definir una política sobre els fluxos migratoris, més l'absència significativa d'altres mesures dirigides a la integració, han convertit el procés d'assentament i definició jurídica de l'estranger en un laberint burocràtic que ha mediatitzat la nostra visibilitat estadística del fenomen (Brancós i Domingo, 2002; Domingo, 2003).

En primer 1loc, ho ha fet influint directament sobre els corrents migratoris, en segon, ho ha aconseguit creant miratges estadístics sovint corresponents a les pràctiques dels migrants per salvar els obstacles per obtenir la seva residència legal al país, i en tercer lloc, s'ha deixat sentir en els propis criteris de recompte $i$ en l'esforç per multiplicar i afinar els registres ja existents. Abans d'analitzar els fluxos migratoris internacionals i les característiques sociodemogràfiques de la població de nacionalitat estran- 
Gràfic 5.1. Evolució dels permisos de residència. Espanya, 1991-2003

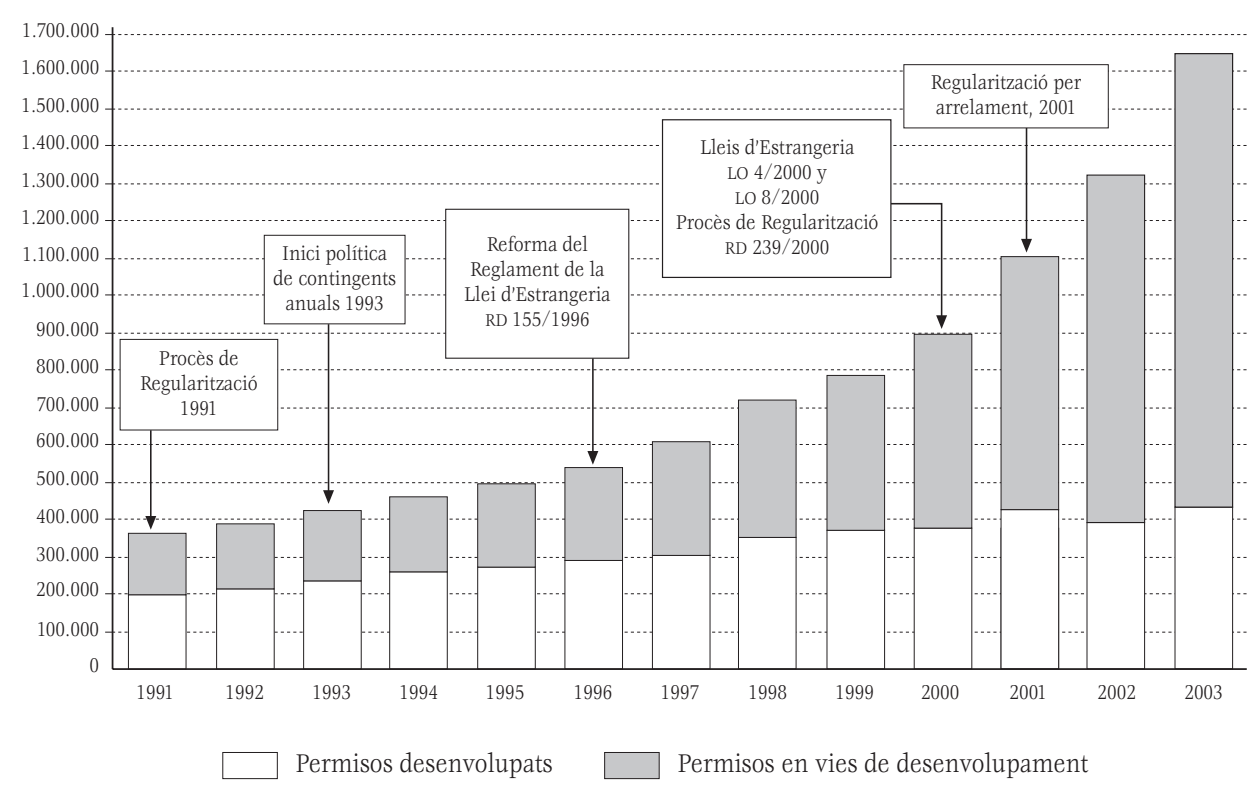

Font: Anuario Estadístico de Extranjería (Comisión Interdepartamental de Extranjería). Elaboració pròpia.

gera a Espanya cal fer doncs un repàs dels canvis legislatius i estadístics abans esmentats, sobretot considerant com aquests han incidit en el propi fenomen i han mediatitzat la nostra percepció.

Al gràfic 1 es pot veure la sèrie corresponent als permisos de residència de la població de nacionalitat estrangera distingint entre els països desenvolupats i els països en via de desenvolupament, assenyalant les principals mesures legislatives que d'una manera o una altra han afectat el recompte de la població de nacionalitat estrangera i per tant la seva visibilitat estadística.

Principals mesures legislatives: de la definició de l'estranger a la irregularitat

Al 1990, la reforma del Codi civil, en l'apartat referent a la nacionalitat (Llei 18/1990, de 17 de desembre), fixa com a requisit per l'accés a la nacionalitat espanyola en dos anys per als nacionals dels països llatinoamericans antigues colònies espanyoles, Filipines, Guinea Equatorial, Andorra 
i la població sefardita descendent dels jueus expulsats d'Espanya el 1492, per a la resta de nacionalitats no pertanyents a la Unió Europea aquest període queda establert en deu anys de residència legal i continuada. Aquesta primera definició determinarà de forma evident la permanència de certes nacionalitats en les sèries estadístiques disponibles, ja sigui dels permisos de residència com de dades de naturalesa censal o padronal. Aquells que estan exclosos de l'accés preferencial romandran en terme mitjà molt més temps com a estrangers davant els nostres ulls, mentre que les nacionalitats afavorides poden desaparèixer dels registres amb més facilitat: la forquilla entre el recompte per origen (lloc de naixement) i per nacionalitat és fa doncs més gran i es decanta significativament segons les nacionalitats.

Però si el primer pas dels noranta va ser redefinir l'accés a la nacionalitat, és a dir, l'estrangeria, el segon, sens dubte, es va aplicar a la irregularitat. La dècada dels noranta i el segle Xxi s'inauguraren amb sengles operacions de regularització extraordinàries, amb volums molt diferents i en contextos diversos, però amb efectes de similars conseqüències en el recompte estadístic i en els corrents migratoris i la població estrangera resultant. El 7 de juny de 1991, es va aprovar la que havia de ser la primera regularització extraordinària d'estrangers a Espanya. Un cop més el ritme de la construcció europea pautava la política espanyola sobre estrangeria: a l'evidència d'una creixent irregularitat en bona part deguda a la rigidesa dels criteris per obtenir el permís de residència i de treball, tant com a la pròpia ineficàcia dels processos burocràtics establerts, hauríem d'afegir les recomanacions expressades pels socis del tractat de Schengen signat el 19 de juny de 1991 directament dirigides a Espanya, en el sentit de reduir el nombre d'irregulars i restringir l'entrada de nous fluxos migratoris a través de les seves fronteres.

El principal efecte sobre el registre estadístic, d'aquesta primera regularització, va ser contradictori: el còmput global de permisos un cop finalitzada l'operació per al conjunt d'Espanya es tancava amb dades inferiors a les de l'any anterior (407.674 per 1990 i 360.655 per 1991). La raó va ser la depuració dels permisos de règim comunitari, restant aquells que estaven caducats, sense incloure en el mateix any les renovacions quan era pertinent fer-ho. D'aquesta manera, el creixement raonablement esperat degut al recompte de les 108.534 regularitzacions va ser contrarestat per les depuracions. L'efecte agreujat per a les sèries estadístiques successives va ser que la incorporació l'any següent dels permisos renovats, majorità- 
riament pertanyents a ciutadans de la resta de països de l'aleshores Comunitat Econòmica Europea donava la impressió de noves entrades.

A part d'aquesta singular peripècia, la gran lliçó (sembla que no apresa) de la regularització va ser el seu efecte pervers sobre el fenomen estrictament migratori: ens referim a l'anomenat «efecte crida». Diguem-ho des de bon començament, les regularitzacions com a peça de polítiques restrictives: 1) retenen població estrangera que podria tornar al país d'origen; 2) anticipen projectes migratoris en el país d'origen fins el moment en estat letàrgic o inexistents; 3) precipiten processos de reagrupament familiar; i 4) poden atreure moviments d'altres països europeus a la recerca de la regularització. No és tracta d'una excentricitat espanyola, sol ser un efecte comú a les regularitzacions, i en general a les mesures de caire restrictiu, com ja es va comprovar en el conjunt dels països europeus receptors de treballadors estrangers i les polítiques aplicades per tal de frenar la immigració i promoure el retorn endegades arran de la crisi econòmica dels anys setanta.

En segon 1loc, però dintre d'aquests mateixos efectes perversos, l'augment dels fluxos que es pensava limitar, incrementa la població que viu en condició irregular, que era precisament el que es volia reduir, i ho fa tant per l'esmentat efecte crida (molts dels nous arribats no compliran els mínims requisits per accedir a la regularització), com per la pròpia arbitrarietat i limitació de les exigències establertes. Així, al 1991, en primera instància es van denegar 19.306 permisos, als que hauríem d'afegir els 28 mil atorgats que no es varen renovar l'any 1992, la majoria dels titulars d'aquest permisos extingits va romandre a territori espanyol en situació irregular. Per últim, s'ha de tenir en compte la precarització que va representar per aquells treballadors que, a més de seguir en situació irregular en no obtenir la regularització, varen perdre el seu treball, rebent com a resposta de l'empresari l'acomiadament quan es trobaven efectivament treballant en l'economia informal.

En tercer 1loc, cal assenyalar que les regularitzacions solen trastocar l'estructura per sexe i edat de la població de nacionalitat estrangera resident, independentment de la seva situació legal al país. En propiciar el reagrupament, encara que es faci en situació de clandestinitat, a la població resultant creix la representació de cònjuges i descendents.

D'altra banda, l'anticipació de projectes migratoris sol a més rejovenir l'edat dels fluxos d'immigrats. Aquests efectes són aguditzats o matisats depenent de les característiques de les cadenes migratòries de cadascuna 
de les nacionalitats representades i és clar, de l'etapa en el procés d'assentament en la que es trobin, o de forma més senzilla, dels anys que fa que existeixen aquest corrents.

Les regularitzacions de 2000 i 2001, d'alguna manera signifiquen una reedició dels efectes d'atracció de la regularització de 1991, però de manera magnificada. Estem parlant de 247.598 sol-licituds a l'any 2000 de les quals es concediren el 66\%, que degut a la insuficiència dels seus resultats, tot i haver prorrogat el termini de presentació, va provocar la convocatòria d'una segona regularització coneguda com Regularización por Arraigo el següent any 2001, amb 351.269 sol-licituds, de les quals a juny de 2002 s'havien estimat el 63,4\%, segons la Dirección General de Ordenación de Migraciones. La comparació entre les dades del Padró continu a 1 de gener de 2003 i els permisos de residència en vigor a 31 de desembre de 2002 ens permeten la primera aproximació a la irregularitat, tot i que s'haurà de tenir en compte que a la sèrie de permisos no hi compten els que estan en període de renovació així com tampoc els estudiants alhora que s'ha de sospitar una certa duplicació del registre del Padró que donaria com a resultat una sobreestimació d'aquesta diferència, el cas és que després de dues regularitzacions extraordinàries a Espanya 1/1 de gener de 2003 ens trobaríem amb un 38\% de la població de nacionalitat estrangera visquent en situació irregular, el que en termes absoluts significa al voltant d'1 milió de persones.

Per últim, conjuntament amb les accions reguladores oficials hauríem de recordar mesures com l'aprovació l'any 1996 del nou Reglamento de la Ley de Extranjería, va fer que sortís a la llum part de la població reagrupada en situació irregular, provocant que l'estructura per sexe i edat tant de fluxos com d'estocs es feminitzés alhora que guanyaven pes els menors d'edat, o com l'anunci de l'exigència de visat als nacionals d'Equador i Colòmbia que també han tingut un important paper en l'acceleració i modificació de l'estructura dels fluxos migratoris dirigits a Espanya.

\section{Principals mesures estadístiques: la presa de consciència i la incertesa}

Les accions legislatives en matèria d'estrangeria durant la dècada dels noranta han anat acompanyades per un notable esforç per millorar, racionalitzar i centralitzar l'aparell estadístic destinat a copsar els fluxos i la situació de la població de nacionalitat estrangera al país, si bé els resultats són prou dispars. 
Gràfic 5.2. Comparació entre les dades dels Permisos de residència a 31 de desembre de 2001, el Cens de població i habitatge a novembre de 2001 i el Padró continu a 1 de gener de 2002

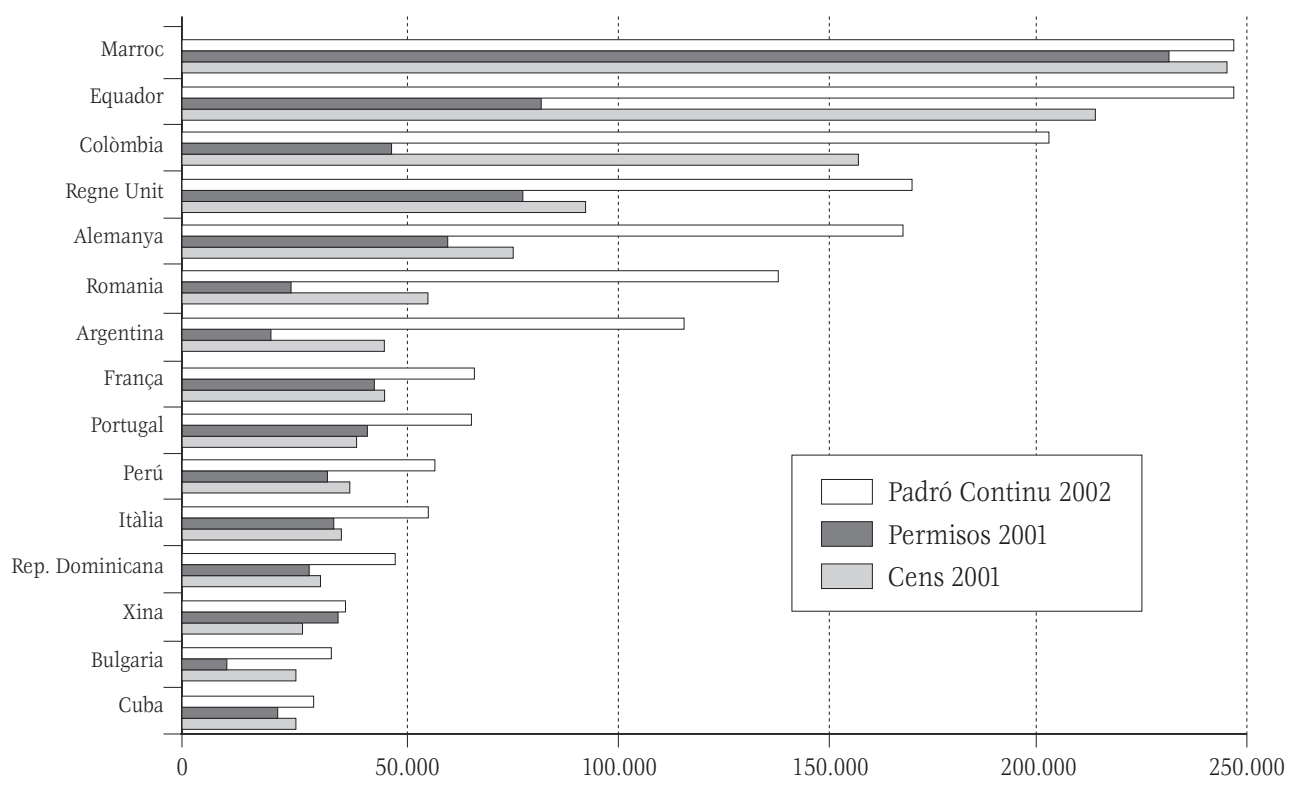

Font: Cens 2001 (INE), Permisos de residència 2001 (Comisión Interdepartamental de Extranjería) i Padró continu 2002.

L'any 1996 és un any cabdal en aquesta matèria, on coincideixen mesures legislatives directa i indirectament relacionades amb els estrangers i la implementació d'un nou registre continu de població, l'anomenat Padrón continuo, que expliquen el creixement en la cobertura estadística de població estrangera.

Aquest any, s'aprovava la Ley Reguladora de las Bases de Régimen Local, establint per primer cop el dret i el deure d'empadronament de totes les persones que resideixen en un municipi, independentment de la seva situació legal. Aquest fet conjuntament amb els rumors que s'acostava una nova regularització i que el paper de l'empadronament podria servir d'acreditació del temps que es portava al país, va canviar absolutament l'anterior estat de subregistre generalitzat, passant en ocasions a la situació oposada de duplicació de l'empadronament per algunes persones de nacionalitat estrangera.

En segon 1loc, des de 1996 s'enceta un nou registre de població sobre la base de les altes i baixes padronals, que permetrà tenir informació de 
la població anualment, i que està destinat a convertir-se en una de les principals fonts sobre els efectius de població estrangera, tot i els problemes que pot presentar heretats de les esmentades deficiències de duplicació de les altes i de la dificultat per enregistrar correctament les baixes. S'ha de pensar que el sistema de construcció del Padró continu a partir dels moviments intermunicipals ignora per complet totes aquelles baixes que es donin amb direcció a l'estranger, sigui per retorn sigui perquè es dirigeixen a països tercers (només al 2002 l'INE va efectuar unes primeres estimacions a partir de dades del registre consular, que temem poc fiables), contribuint a engreixar encara més el resultat del Padró continu, conjuntament amb aquelles duplicacions degudes a errors involuntaris o a la picaresca per poder accedir a beneficis relacionats amb hipotètiques regularitzacions.

Per últim, com ja apuntàvem, la discrepància entre les diferents fonts coincidents en el temps, Cens de població i habitatge de novembre de 2001, permisos de residència en vigor a 31 de desembre de 2001 i Padró continu d'1 de gener de 2002, obren clars interrogants sobre la validesa de les diverses fonts en la cobertura de la població estrangera, alhora que representen un toc d'atenció sobre la magnitud de la irregularitat després de dues operacions regularitzadores i una dècada de política manifestament restrictiva, on la lluita contra la irregularitat apareixia enunciada com a objectiu principal.

La disparitat entre les dades referents al Padró continu i les dels permisos de residència, per a dates coincidents no ha fet res més que créixer, i tot i que la comparació immediata entre els permisos en vigor i els empadronats no és el nombre exacte de persones en situació irregular, no deixa d'alertar-nos sobre una mesura que en la seva aproximació s'ha de considerar com força preocupant.

\section{ACCELERACIÓ I DIVERSIFICACIÓ DE FLUXOS I D'EFECTIUS}

\section{La latinoamericanització dels fluxos}

Un cop d'ull a l'evolució dels fluxos, tot i el subregistre endèmic de la font i veurem com és a partir de la segona meitat dels noranta que es disparen: el 85\% de les 1.723.261 entrades registrades entre 1991 i 2002 corresponen a les produides entre 1997 i 2001, més encara, el 73\% correspon 
Gràfic 5.3. Fluxos internacionals arribats a Espanya per grans agrupacions continentals, 1991-2002

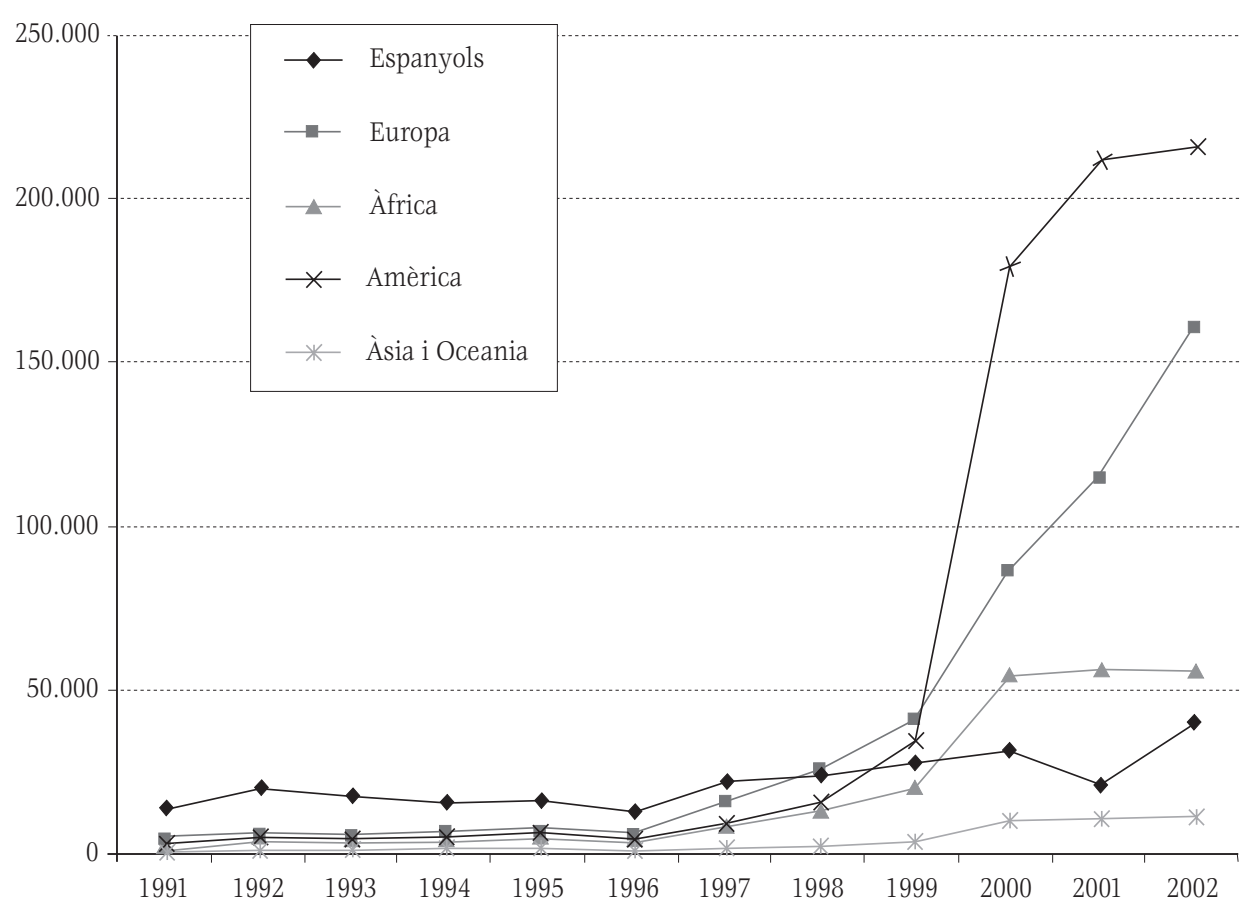

Font: Estadística de Variaciones Residenciales (INE).

als tres primers anys de la dècada del 2000 en clara connexió amb els processos de regularització abans esmentats. Però juntament amb l'acceleració dels fluxos, els que més destaca ha estat la seva diversificació i la diferent evolució per orígens, tal i com es pot apreciar al gràfic 3.

Si bé tots els corrents experimenten creixements importants, Amèrica llatina destaca amb molt per sobre els demés, representant ella sola més de la meitat del flux internacional d'estrangers registrat aquests tres darrers anys, ralentitzant-se fins i totes les entrades corresponents al continent africà.

La puixança de la immigració llatinoamericana, afavorida per la voluntat implícita d'efectuar una substitució ètnica dels principals fluxos migratoris, palesada a les operacions de regularització, ha fet parlar alguns autors de clara preferència (Izquierdo, López de Lera i Martínez Luján 2002). 
Aquest increment continental ha tingut dos clars protagonistes: 1'Equador i Colòmbia. Si bé la presència de migració equatoriana es pot relacionar amb la forta crisi econòmica d'aquest país a partir de la dolarització de la seva economia l'any 1996, i la colombiana amb el greu deteriorament de les condicions socioeconòmiques del país, l'excepcional increment d'ambdós països Equador i Colòmbia pot explicar-se a més per l'efecte incentivador sobre projectes migratoris de l'anunci de demanda de visat per ambdós països, com efectivament es va exigir a partir de l'any 2002.

També cal assenyalar, que les modificacions en l'accés a la nacionalitat per a descendents d'antics migrants espanyols en països llatinoamericans contribuirà sens dubte a la repuntada dels fluxos d'espanyols procedents de l'estranger, situació que clarament ja s'està produint en el cas dels argentins (que abans ja arribaven com nacionalitzats italians).

\section{Heterogeneïtat de la població de nacionalitat estrangera resident a Espanya}

Com era d'esperar, el canvi en la composició de fluxos ha repercutit en la distribució dels orígens per als efectius de població, així de 1991 a 2003, la població europea ha vist minvar la seva representació del 50 al 34\% en benefici de llatinoamericans, del 23 al 32\%, i africans del 17 al 26\%, tenint en compte que l'any 2000 havia arribat a assolir en termes relatius un màxim del 29\% com es pot veure al gràfic 3 .

I encara haurem de recordar que els requisits per accedir a la nacionalitat espanyola segons es va establir a la reforma del Codi civil de desembre de 1990 (Llei 18/1990) beneficiava clarament les persones de nacionalitat llatinoamericana front d'altres estrangers, essent d'aquesta manera més probable que hagin desaparegut del registre en obtenir la nacionalitat espanyola.

Si es considera l'evolució per nacionalitats, i utilitzant les darreres dades corresponents permisos de 2003, encara es fa més palesa la diversificació d'orígens i el canvi de pes, sempre dins la constant d'una major presència dels països en via de desenvolupament. Si a l'inici de la dècada el Marroc, els Estats Units d'Amèrica i les Filipines eren les úniques nacionalitats no pertanyents a la Unió Europea entre les deu primeres amb el segon, el setè i desè 1loc respectivament, a 2003 Marroc ha passat a ser la primera nacionalitat concentrant el 20\% de tots els residents, seguida de l'Equador amb el 10,6\%, i Colòmbia la tercera amb el 6,5\%, havent de comptar Perú, Xina, 
Gràfic 5.4. Permisos de residència a Espanya, 1991-2003.

Percentatges per agrupacions continentals

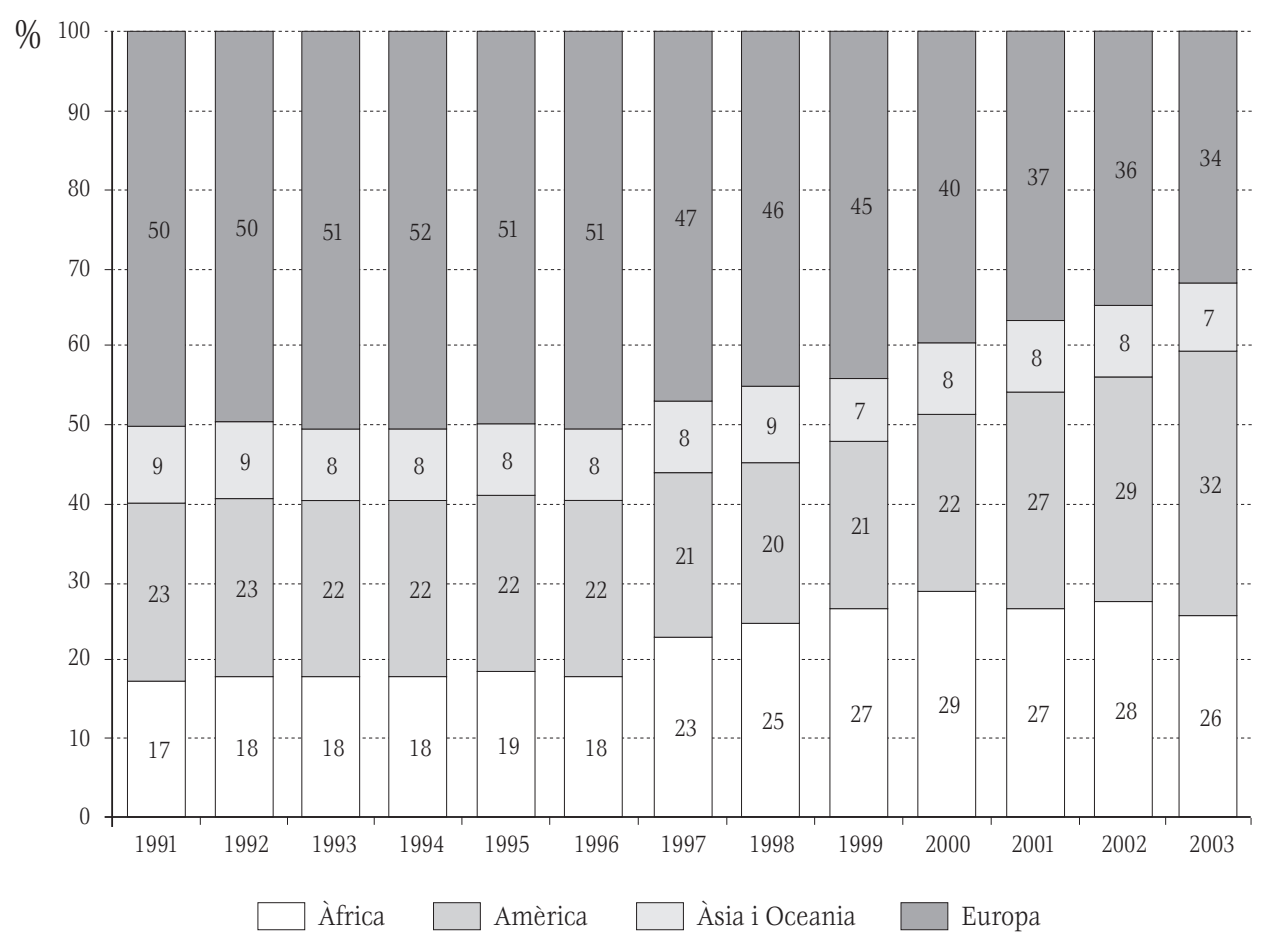

Font: Anuario Estadístico de Extranjería (Comisión Interdepartamental de Extranjería).

i Romania entre les deu primeres nacionalitats. Si fem el mateix exercici amb les dades del Padró continu a 1 de gener de 2003, és a dir, un any abans que les corresponents als permisos de 2003 (31 de desembre) l'Equador amb 382.169 empadronats, el 14\% de tota la població de nacionalitat estrangera ja ha desbancat al Marroc, que amb 352.452 empadronats i el 13\% del total ocupa la segona posició (veure gràfic 4).

Tot i que el conjunt dels estrangers censats al 2001, es caracteritzin per ser una població jove (29\% entre 25 i 34 anys) i amb una relativa igualtat quant a la representació dels sexes (48\% són dones), la diversificació dels orígens de les persones de nacionalitat estrangera resident a Espanya també s'ha acompanyat d'una creixent complexitat quant a l'estructura per sexe i edat. A tall d'exemple podem observar les piràmides de població amb l'estat civil de les principals nacionalitats per a cada grup continental, 
Gràfic 5.5. Distribució percentual dels estrangers segons les 15 primeres nacionalitats a Espanya, segons dades del Padró continu a 2003

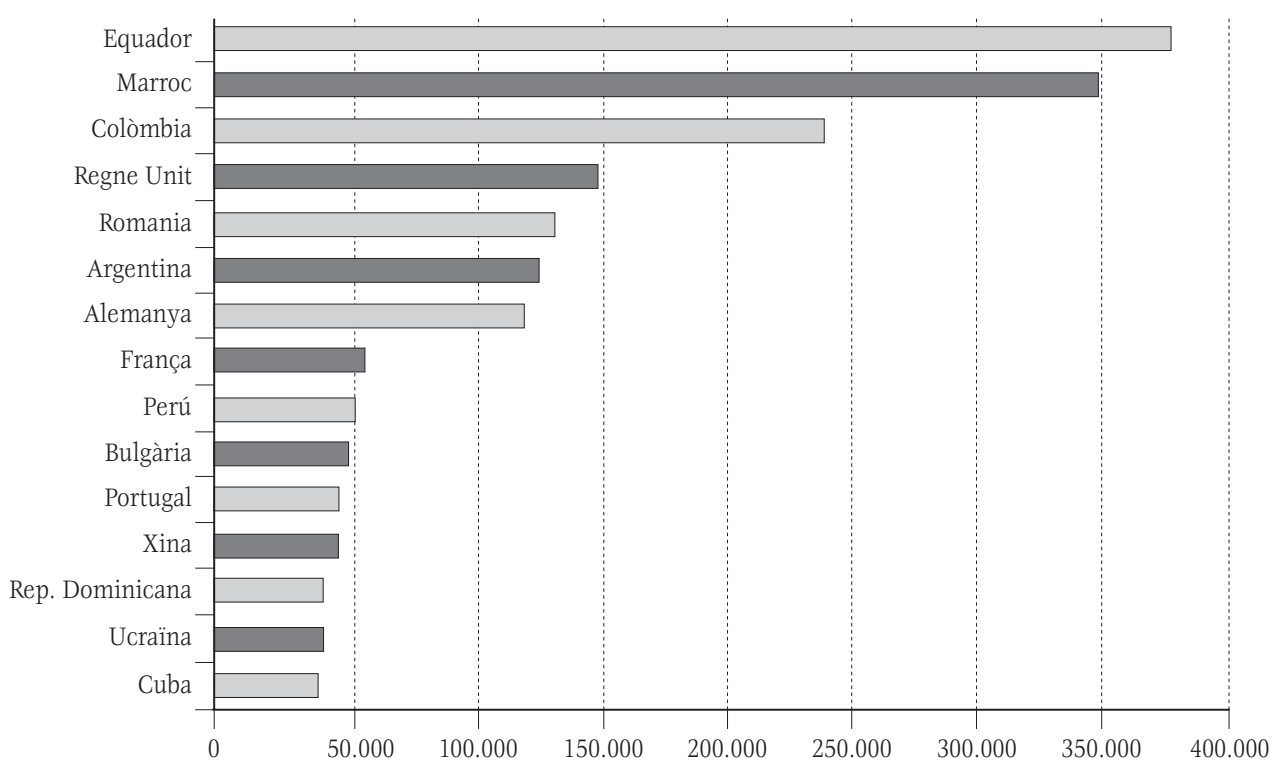

Font: Anuario Estadístico de Extranjería, 2003 (Comisión Interdepartamental de Extranjería).

1'heterogeneitat és manifesta: la simetria de nacionalitats com Regne Unit (49,5\% de dones), l'Equador (51\%) o la Xina (45\%) que ens parla de 1'assentament de grups familiars contrasta amb la forta masculinització de la població pakistanesa (87,5\% homes) o senegalesa (75,5\% homes) o, en l'extrem oposat, la encara forta feminització de la població colombiana (58\% dones), on clarament ens trobem amb una població producte de les primeres etapes del cicle migratori.

Per altra banda, la piràmide britànica extremadament envellida ens tradueix un caràcter completament diferent amb el 24\% població major de 64 anys, òbviament la migració de persones jubilades per aquesta nacionalitat és tan important com la migració econòmica. El nombre de població soltera, i separada o divorciada, sobretot per aquelles nacionalitats on la cohabitació és mínima, així com el nombre de persones casades que no resideixen amb la seva parella ens parla d'un gran potencial de reagrupament familiar o com a mínim de la importància que la dinàmica familiar tindrà els propers anys entre la població de nacionalitat estrangera resident a Espanya. 
Figura 5.1. Piràmide de població del total d'estrangers i de diferents nacionalitats per estat civil. España, 2001

$\square$ Solters/es

$\square$ Casats/des

- Vidus/es

$\square$ Separats/des o divorciat/des
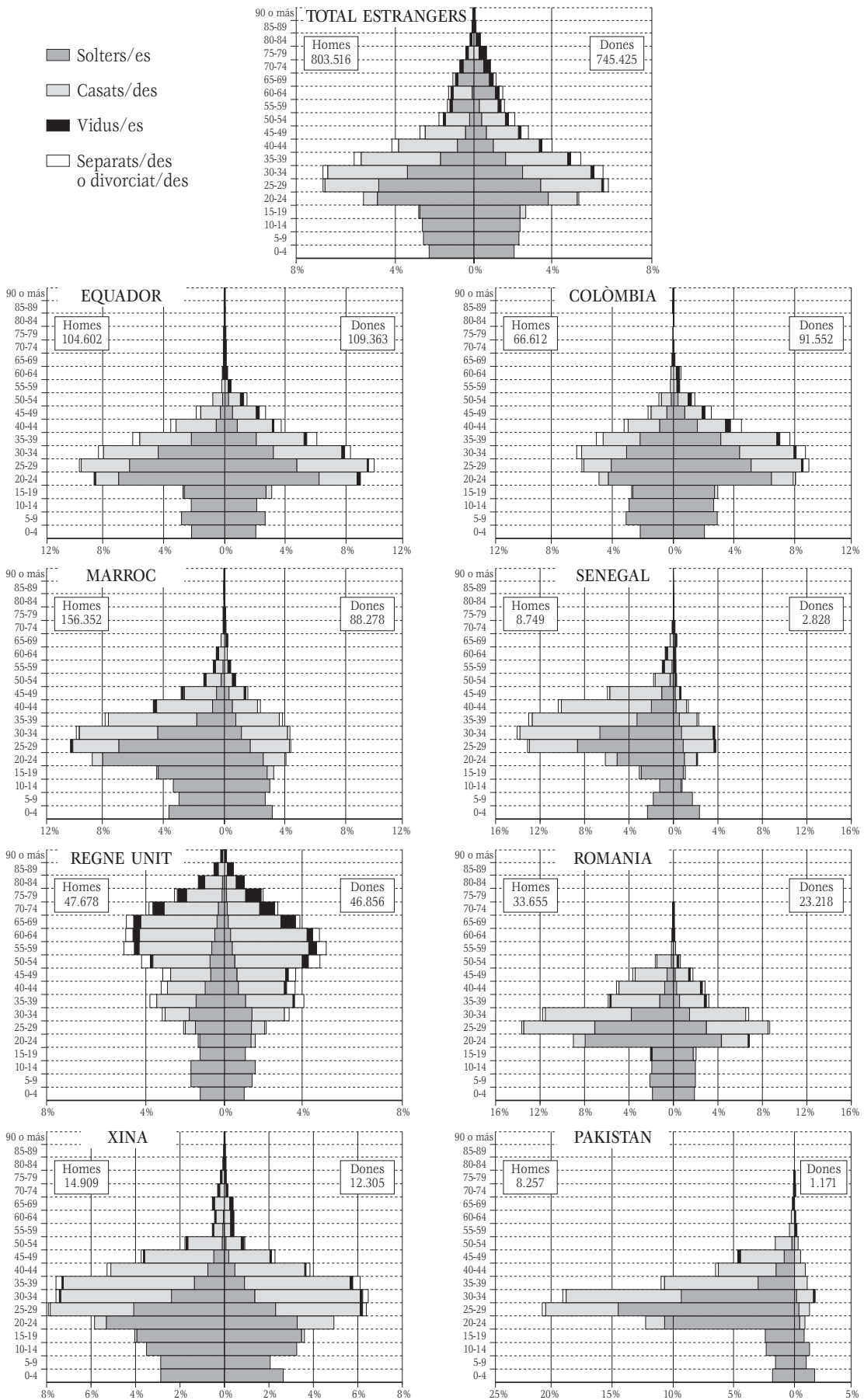

Font: Cens de població de 2001. 


\section{DISTRIBUCIÓ TERRITORIAL}

Limpacte de la immigració internacional i de la distribució espacial de la població de nacionalitat estrangera sobre el territori és molt diferent depenent de la divisió administrativa que considerem. En conjunt, el creixement dels efectius de població estrangera s'ha traduit en una major presència arreu: la dècada dels noranta ha significat que a hores d'ara la immigració estrangera sigui un fenomen present a la majoria de municipis, només a el 19\% dels municipis espanyols no es trobava cap estranger empadronat l'any 2003.

Aquesta difusió pel territori, no ha alterat substancialment l'ordre de la concentració segons les províncies, tant si tenim en compte la distribució dels estrangers de cada província sobre el total de la població estrangera (mapa 1), com si considerem la proporció que representa la població estrangera sobre el total de la població empadronada als municipis de la província (mapa 2). La distribució espacial tradueix la geografia de l'activitat d'aquells sectors que més empren la mà d'obra estrangera: 1'agricultura, l'hosteleria, la construcció, el servei domèstic i el comerç, palesant, com han assenyalat diversos autors l'existència de mercats locals especialitzats pels migrants (Colectivo Ioe, 2002). Madrid i Barcelona segueixen essent amb un 22 i un 15 per cent les províncies que aglutinen el major nombre d'estrangers, seguides d'aquelles que se situen al litoral Mediterrani i les Illes Balears i Canàries.

La comparació amb les dades padronals de 1996 posen en evidència el creixement de les migracions internacionals durant aquest període, ja que encara que es pugui considerar que al Padró de 1996 hi ha encara un important subregistre el salt del 5\% d'Alacant com a màxima proporció d'estrangers sobre el total de la població el 1996 al 15\% el 2001 és prou eloqüent, el mateix val a dir amb les Balears, Girona, Madrid i Almeria depassant totes elles el 10\%. Alhora que s'estenia la seva presència sobre el territori doncs, també augmentava la concentració en algunes de les províncies receptores d'immigració, fet que ha provocat que alguns autors assenyalin que l'assentament de la població estrangera augmenta el desequilibris poblacionals ja preexistents (Reques i De Cos, 2004).

La distribució territorial de les principals nacionalitats de cada gran grup continental evidencien l'especialització geogràfica dels migrants, hi ha nacionalitats com el Pakistan on una única província, Barcelona, concentra a la meitat de tots els migrants del colllectiu, mentre que les més nombroses 
Figura 5.2. Distribució de les persones de nacionalitat estrangera en el territori espanyol

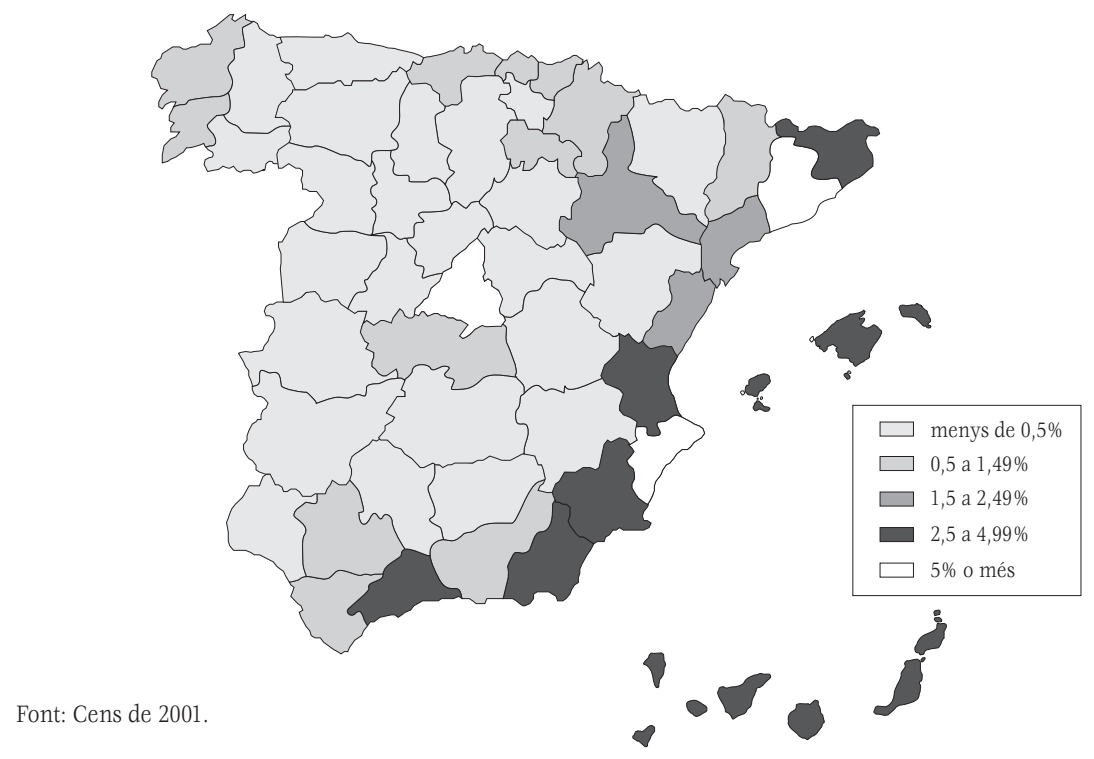

Figura 5.3. Pes de la població estrangera sobre el total de la població de les províncies espanyoles

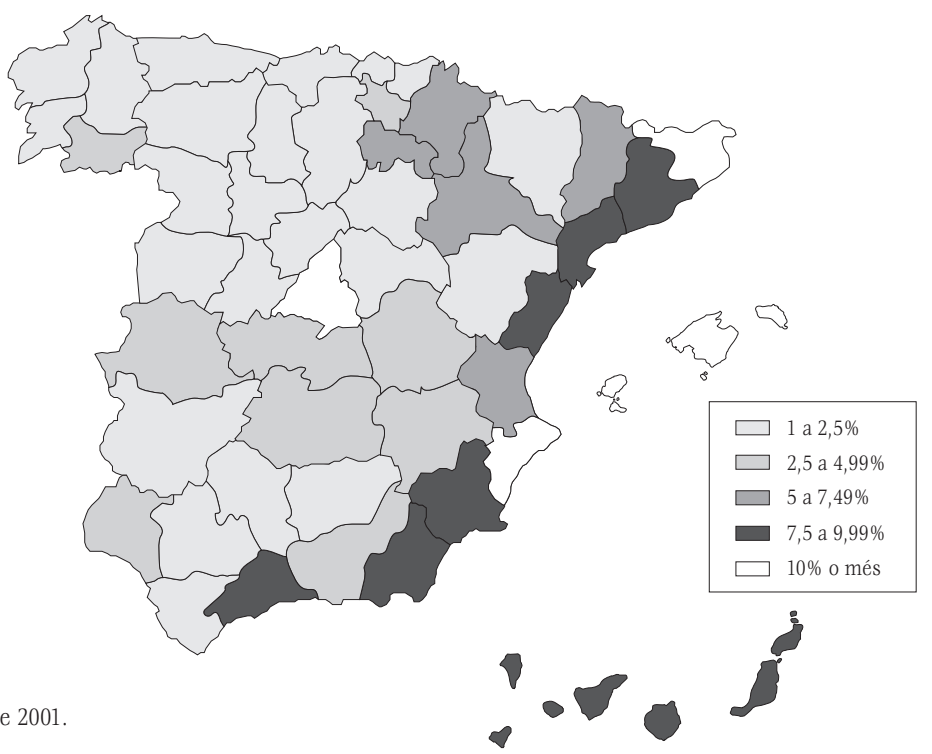

Font: Cens de 2001. 
Figura 5.4. Distribució territorial de les principals nacionalitats estrangeres
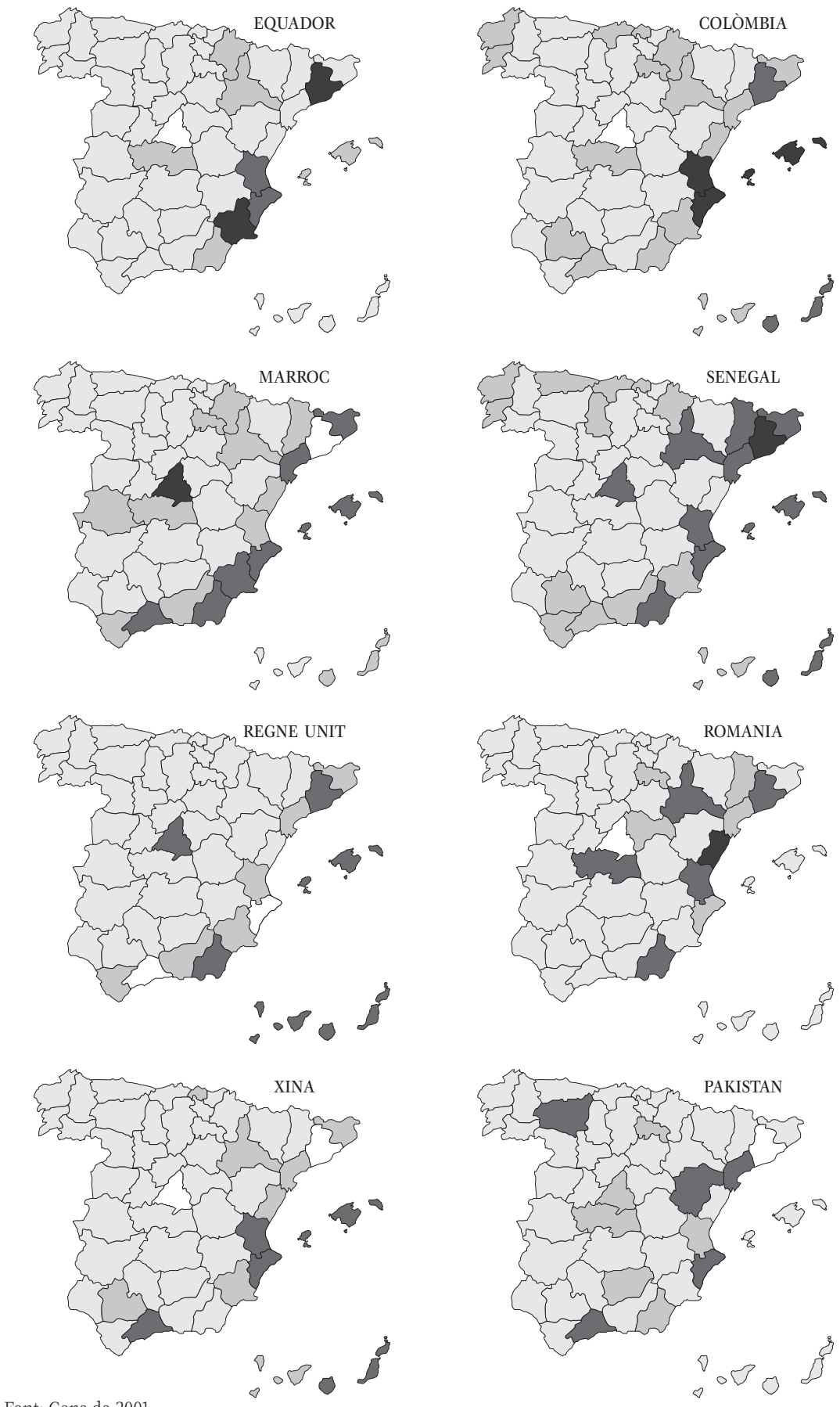
i esteses en el territori com el cas colombià o l'equatorià, posen de manifest clarament l'activitat disseminant-se en el territori seguint eixos de sectors productius, com és el cas l'agrari en l'Ebre o en el litoral mediterrani des d'Almeria fins a València. Per altra banda, la distribució costanera i central del Regne Unit, exemplifica també la dualitat dels seus corrents migratoris, amb presència de persones jubilades presumiblement concentrades als municipis costaners de la Mediterrània i les Canàries, i migrants activament econòmics més joves, amb independència que a més de Madrid també es trobin en els mateixos municipis costaners, part d'ells per una demanda específica generada pels propis jubilats britànica. El cas de Marroc i Romania és interessant des de la perspectiva de la substitució ètni$\mathrm{ca}$, ja que la primera nacionalitat, amb corrents migratoris molt més antics comparteix el territori i segurament l'activitat en bona part de les províncies on posteriorment han arribat els romanesos.

Per últim, la distribució del Senegal és interessant si s'observa el tipus d'ocupació per comprovar com una mateixa nacionalitat pot acabar tenint presència en diferents territoris i amb activitats força contrastades com les que realment tenen. D'aquesta manera un collectiu que tradicionalment s'associa amb la venda ambulant com a major activitat, efectivament es dedica com a primera ocupació a la venda ambulant en totes les províncies excepte a Barcelona, Girona i Lleida on apareixen en primer 1loc com a peons de la construcció i manobres, a La Rioja, Osca, Saragossa, Terol i Almeria on s'ocupen principalment com a peons agraris o ramaders.

D'aquesta manera, a part de la selecció que el territori fa respecte a la distribució de les diferents nacionalitats, i que s'explica per la pròpia història migratòria i l'establiment d'un camp migratori entre el lloc d'arribada i el lloc d'origen, haurem d'afegir una segona selecció en la que el territori marca amb tanta o més intensitat que la nacionalitat l'activitat, però també l'espai social que ocuparà el migrant.

FACTORS SOCIODEMOGRÀFICS QUE EXPLIQUEN L'ARRIBADA D'IMMIGRANTS: SEGMENTACIÓ I COMPLEMENTARIETAT

Fins aquí hem fet una primera aproximació a l'evolució recent dels fluxos i a la població estrangera censada al 2001 i les diferències en la seva distribució territorial. Però a part de constatar l'efecte de la legislació en el creixement dels efectius i que la pròpia estructura jove d'aquesta població 
ens permeten preveure un augment sostingut pels propers anys, hauríem d'entendre els factors intrínsecs a la pròpia evolució sociodemogràfica d'Espanya que expliquen l'arribada i futura demanda d'immigració internacional de caire econòmic. Aquests factors són tant o més decisius que les condicions dels països d'origen que justifiquen la necessitat de migrar dels protagonistes dels corrents migratoris, a més de traçar la topografia de l'espai social destinat als migrants.

Mentre que la legislació espanyola s'entestava a restringir els fluxos i dificultar l'assentament de la població de nacionalitat estrangera i, com hem vist, aconseguia engrandir el nombre d'irregulars en proporcions alarmants, l'evolució demogràfica del conjunt de la població espanyola seguia reorientant-se donant un lloc cada cop més important a la immigració internacional, que pot ser compresa en termes de complementarietat social, on la segmentació del mercat de treball és el més important però no l'únic factor d'atracció. Aquesta nova reorientació s'ha d'entendre a partir de dos processos que han revolucionat l'evolució demogràfica però també l'estructura social dels països desenvolupats a partir de la segona meitat del segle xx: el procés de reordenació de les edats i la redefinició dels papers de gènere (veure Domingo, 2002).

\section{La redefinició dels papers de gènere}

L'equiparació dels rols que ha impulsat la redefinició dels papers de gènere ha tingut clars efectes sobre la dinàmica demogràfica, i si no en són la causa directa, n'han format part: la reducció de la fecunditat, la davallada de la nupcialitat, l'augment de la divorcialitat, la desinstitucionalització dels lligams familiars, i per tant l'aparició de la cohabitació i l'augment de fills nascuts fora del matrimoni, a més de l'emergència de més o menys noves estructures familiars (famílies monoparentals i reconstituïdes), en poden ser una bona prova. Limpacte del procés d'equiparació dels sexes s'ha deixat sentir sobretot, encara que no únicament, a la dinàmica demogràfica que afecta la formació de la família i a les estructures de la llar i familiars resultants, en el pas d'un model asimètric basat en el repartiment de rols per raó de sexe a un model de simetria basat en l'equitat en el repartiment, el que Anna Cabré ha anomenat «transició familiar» (Cabré, 1995). Una de les característiques més importants d'aquest procés a Espanya ha estat haver començat molt més tard que als països nòrdics, pioners entre els europeus, i haver de fer front a aquests canvis en un context de forta 
crisi econòmica com ho va ser la de mitjans dels setanta, i amb un Estat de Benestar feble en comparació al dels països septentrionals. El resultat d'enfrontar aquestes transformacions amb menys recursos i més tard ha aguditzat molt més els resultats en termes d'intensitat (així s'expliquen els mínims mundials de fecunditat), deixant a les xarxes familiars l'assumpció de la majoria dels costos socials, a part de la repercussió negativa sobre la pròpia biografia de les generacions femenines espanyoles.

Dos dels avenços espectaculars que ha comportat aquesta equiparació dels rols en l'evolució sociodemogràfica espanyola, estretament relacionats, són la inserció creixent de la dona en el mercat de treball i les millores experimentades en els nivells d'instrucció de les dones de les joves generacions. Així, si l'activitat de les dones espanyoles en conjunt apareix per sota de la mitjana europea, l'activitat de les dones entre 25 i 29 anys supera amb escreix aquesta mitjana colllocant-se entre els primers 1locs d'Europa, afegint a més la característica de ser una inserció laboral molt més a temps complert (més semblant al patró masculí) que no pas les pautes dels països amb major participació femenina, on aquesta inserció s'efectua a temps parcial. Laugment de la participació femenina en el mercat de treball i la quasi universalització de les parelles de doble ingrés, ha plantejat amb urgència el dèficit de l'equiparació dels sexes en el terreny del treball domèstic.

En bona part, les millores del nivell d'instrucció de les dones que expliquen les seves altes expectatives laborals, així com la pròpia materialització de l'entrada en el mercat de treball han estat possibles gràcies a l'assumpció de l'entorn familiar del treball domèstic. En concret hauríem de posar de relleu el treball intensiu de les dones de les generacions nascudes a mitjans dels anys trenta en aquesta revolució de gènere. Aquestes dones, que han sigut les que més s'han casat durant el segle xx, són les que a la pràctica han sostingut el retard de l'emancipació juvenil, alhora que moltes vegades segueixen assumint el treball domèstic de les llars dels seus fills i filles ja emancipats, i la cura de persones dependents, ja sigui dels infants (néts) ajudant a conciliar la vida familiar i laboral dels seus descendents, ja sigui de persones grans, les seves pròpies mares o germanes que gràcies a l'allargament de l'esperança de vida han sobreviscut. Quan aquest treball s'externaliza fora de la família, en un país com Espanya on l'Estat de Benestar és relativament feble en comparació als models nòrdics, el recurs a la mà d'obra femenina estrangera és creixent. Així, les estrangeres ocupades al sector domèstic segons el Cens de 2001 assolien ja el 30,5\% de tot el sector, 
i si ens fixem només en les que tenien entre 25 i 29 anys el 43\%. Si tenim en compte que quan les dones espanyoles nascudes als anys trenta comencin a ser significativament depenents degut a l'envelliment les seves filles no podran seguir assumint la intensitat del treball domèstic, la potencialitat de la demanda en aquest terreny augmentarà encara més. Des d'aquesta perspectiva haurem d'entendre que la inserció de dones de nacionalitat estrangera en el mercat de treball és clarament complementària a la promoció de les de nacionalitat espanyola i que, en general, facilita la conciliació de vida familiar i laboral tant d'homes com de dones espanyols.

Com és evident, la participació laboral de dones de nacionalitat estrangera no es limita al treball domèstic, essent les taxes d'activitat de les dones estrangeres superior en conjunt al de les espanyoles, i presentant també elles una forta especialització que cobreix una àmplia gamma de professions, si bé en termes de distribució de la pròpia població ocupada femenina els sector d'hosteleria i altres serveis són els més representats després del servei domèstic i la neteja d'oficines, hotels i assimilats. Encara que les seves pautes d'activitat siguin força diverses segons l'origen de les migrants (mínim per les africanes, 37\%\%, i màxim per les llatinoamericanes, 60\%). La incorporació relativament precoç de les estrangeres i el manteniment de nivells màxims per totes les edats, amb l'esmentada excepció africana, contrasta amb les pautes de les espanyoles, relativament molt més tardana i amb franc protagonisme de les joves entre 25 i 29 anys com a abanderades de la transformació generacional.

\section{Reordenant les edats}

La redefinició de les edats és clarament deutora de l'extraordinari allargament de l'esperança de vida experimentat als països desenvolupats: sembla clar que la democratització de la supervivència, que cada cop arribi més gent a edats avançades i en millors condicions, ha fet prendre consciència de la vellesa com a grup d'edat amb un pes creixent dins la població, tant numèricament parlant com per la necessitat de reformar la seva participació en la societat tenint en compte el seu estat de salut i la progressiva millora en el nivell d'instrucció de les generacions que arriben a grans (Pérez, 2003). No tan evident, però també relacionat, pensem que ha estat el perllongament del període que anomenem joventut, aquell període de semidependència que, en general, hauria de desembocar en la completa emancipació econòmica, familiar i residencial (Garrido i Requena, 1996). 
És com si, part dels anys guanyats al final de la vida, es poguessin invertir dilatant el temps caracteritzat per la centralitat de la formació, a nivell collectiu, per la inversió en capital humà. És en aquests termes en els que conjuguem els efecte de l'allargament de l'esperança de vida i les expectatives d'inserció en el mercat laboral creades per la millora espectacular dels nivell d'instrucció de les joves generacions que comprendrem el paper complementari que estan jugant els migrants de nacionalitat estrangera.

Lallargament de l'esperança de vida, ha estat, sens dubte, un dels fenòmens demogràfics més destacables dels que s'han produit en el darrer quart de segle en els països desenvolupats. Si a principis dels seixanta la mitjana de l'esperança de vida en néixer de la Unió Europea dels 15 se situava al voltant dels 73 anys per a les dones i els 67,4 pels homes, en encetar el segle XXI havia augmentat en més de 7 anys per les dones i de 8 pels homes. Al final d'aquest mateix període, Espanya encapçala la classificació amb 83 anys per les dones i 75,6 pels homes al 2001. L'efecte més conegut d'aquesta espectacular evolució conjugada amb un descens vertiginós de la fecunditat ha estat el procés d'envelliment de la població i els seus efectes, així si al 1960 el percentatge de població major de 64 anys a Espanya a penes arribava al 8\%, al 2001 s'arriba al 17\%, però tan o més important que aquest procés hem de considerar les repercussions sobre la família i sobre la redefinició de les edats.

L'efecte més important sobre l'estructura familiar ha estat el que anomenem emergència de la quarta generació i verticalització de la família, és a dir, la generalització d'estructures familiars caracteritzades per la supervivència dels progenitors i ancestres més que no pas per l'extensió dels coetanis, corresponent a l'increment de les probabilitats de supervivència de persones d'un mateix llinatge, el que s'ha anomenat emergència de la quarta generació (vegeu Pennec, 1996; Cabré i altres, 2000). Els primers efectes d'aquesta supervivència en relació a l'equiparació de les dones i l'atracció de mà d'obra femenina ja comentats en l'apartat anterior, cal només afegir que pel cas d'Espanya s'ha estimat que, mentre les generacions femenines nascudes abans de 1930, la possibilitat de pertànyer a un llinatge de quatre generacions sobrevivint al mateix moment només afectava al 20\% dels efectius, essent els 27 anys el punt màxim, la mateixa probabilitat per a la generació femenina nascuda entre 1970 i 1974 arribarà a un màxim als 28 anys amb gairebé el 45\% de totes les dones de l'esmentada generació pertanyents a un llinatge de 4 generacions femenines en vida (Cabré i altres, 2000). 
Gràfic 5.6. Comparació dels nivells d'instrucció dels espanyols censats al 2001, per sexe i grups d'edat

\% PERSONES DE 15-64 ANYS

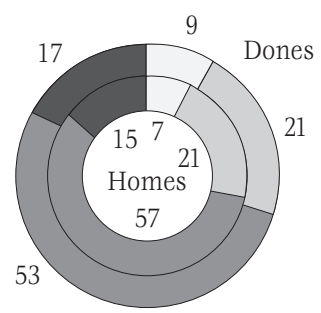

Sense estudis
\% PERSONES DE 25-29 ANYS

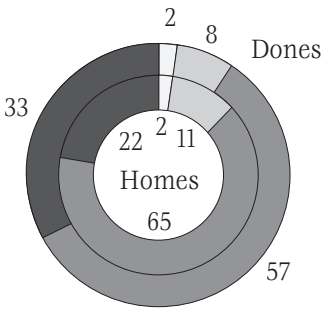

Segon grau
\% PERSONES DE 60-64 ANYS

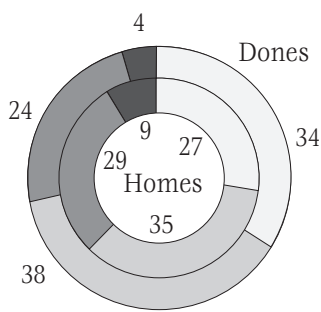

Tercer grau

Font: Cens de Població i Habitatge, 2001 (INE).

Si ens fixem en la redefinició de la construcció social de les edats, especialment en l'impacte sobre el període anomenat joventut haurem de veure com a Espanya l'allargament de la dependència estretament 1ligat a l'augment de la instrucció de les generacions a partir de la crisi econòmica de mitjans dels setanta ha estat una constant. A les dificultats d'entrada en el mercat de treball que va caracteritzar els setanta i els vuitanta, s'hauria d'afegir les dificultats d'emancipació domiciliar i la precarització dels contractes que durant els darrers anys han sostingut aquest extraordinari allargament. Per fer-nos el càrrec de la fractura que a nivell generacional suposa l'avenç en el nivell d'instrucció, podem veure com a través de les dades censals mentre que la població espanyola nascuda entre 1937 i 1941 i censada al 2001 el nivell d'instrucció superior representava pels homes el 8,7\% del total i per les dones el 4,4\%, per als nascuts entre 1972 i 1976 aquests percentatges han augmentat fins al 22,3\% en el cas dels homes i el 32,9\% en el cas de les joves. Veure 1'extrem oposat, els nivells inferiors d'instrucció, on la tercera part de les dones que viuen censades a Espanya el 2001 entre 60 i 64 o no va anar a escola o és analfabeta, dóna una idea del vertiginós canvi en la instrucció femenina en el país, passant com es pot veure en l'actualitat a superar els nivells de les mateixes generacions joves masculines. Les expectatives d'inserció en el mercat de treball d'aquestes noves generacions masculines i femenines explica la creixent demanda per llocs de treballs per als quals les persones de nacionalitat espanyola es troben sobrequalificades. 
Des d'aquesta perspectiva, la complementarietat amb l'arribada de persones de nacionalitat estrangera sembla òbvia. En termes ja no d'estratègia individual del jove, sinó d'estratègia familiar, tenint en compte que l'esforç d'inversió en capital humà que significa l'allargament del període dedicat a la formació, sembla prou raonable que es mantinguin unes altes expectatives en la inserció al mercat.

Si a més es té en compte que amb l'inici del segle xxi estan arribant al mercat de treball les generacions cada cop menys nombroses nascudes a partir de 1976, quan la fecunditat cau dràsticament, entendrem que els propers anys estaran marcats per una escassetat relativa de mà d'obra jove, suplida entre d'altres jaciments laborals pels immigrats de fora d'Espanya. Un cop més no sembla forassenyat pensar la concurrència en el mercat en termes de complementarietat, en aquest cas entre la població de nacionalitat estrangera i la promoció dels joves espanyols, sense descartar que a certes branques d'activitat aquesta complementarietat es tradueixi en un procés de substitució, o que en determinats sectors entrin en competència. Així, entre els homes, el 24\% dels peons agrícoles, el 20\% dels dedicats a la ramaderia censats a Espanya el 2001 eren de nacionalitat estrangera, tot i que en termes de la distribució dels propis estrangers ocupats per professió els percentatges més elevats siguin els peons de la construcció $(9,6 \%)$ i els manobres $(8,4 \%)$ després dels peons agrícoles $(10 \%)$.

\section{CONCLUSIONS: COMPLEMENTARIETAT I EXCLUSIÓ}

Lascens de la immigració a Espanya durant la dècada dels noranta, especialment en el transcurs del darrer quinquenni, resulta d'unes proporcions majúscules: ha consagrat un país que havia estat tradicionalment emigratori com immigratori, situant-lo a les portes del segle Xxi per damunt de la mitjana europea quant a la proporció d'estrangers residents al seu territori en relació al total de la població. Paradoxalment, aquest creixement s'ha vist impulsat per mesures polítiques en matèria d'immigració i estrangeria que es presentaven com voluntàriament restrictives i per d'altres que, sense explicitar-ho, perseguien una substitució ètnica dels principals orígens dels fluxos. Així s'entén en part l'alça accelerada de la població empadronada llatinoamericana i de l'Est d'Europa.

Més enllà de les causalitats espúries de certs indicadors demogràfics sovint esgrimides per explicar l'existència de corrents migratoris, la baixa 
fecunditat o l'envelliment, l'evolució sociodemogràfica d'Espanya en el darrer quart de segle ajuda a comprendre la forta atracció exercida per un mercat de treball segmentat i la previsió que aquesta demanda augmenti de forma també espectacular durant el proper decenni. Les raons dels moviments humans de caire internacional reactivats per la globalització, cal cercar-les als desequilibris econòmics entre les àrees emissores i receptores de població, on la voluntat individual de migrar segueix la legítima aspiració de millorar les condicions de vida pròpies i familiars. L'evolució demogràfica de les zones emissores, que en general s'han caracteritzat fins fa poc per un creixement notable i una estructura de la població jove, explica més la potencialitat de l'emigració, en termes d'efectius disponibles, que no pas les causes de la mateixa. Seguint estrictament aquesta consideració es pot establir una clara continuitat històrica amb les migracions econòmiques al llarg del temps, les que es produien entre diferents estats així com les que es produien dins un mateix estat. Per algunes regions doncs, les migracions internacionals signifiquen l'ampliació transfronterera d'un sistema demogràfic basat en la immigració, per d'altres en canvi, com per al conjunt de l'Estat espanyol, una veritable revolució demogràfica.

Hem provat d'interpretar en termes de complementarietat els factors sociodemogràfics que, al nostre parer, estan a l'origen de l'actual dinàmica migratòria internacional dirigida a Espanya i el que significa la presència de contingents cada cop més importants de població de nacionalitat estrangera entre nosaltres. Ens referim al paper complementari que juga la vinguda de dones de nacionalitat estrangera en la inserció de les joves espanyoles al mercat de treball $i$ a la subsidiarietat que representa l'arribada de migrants estrangers també en la promoció social dels joves de nacionalitat espanyola. El que està succeint a Espanya no és una excepció en comparació a la resta d'Europa, però com en d'altres processos demogràfics, l'endegament tardà de la transició compensada per la intensitat són les característiques diferenciadores. En un context de relativa precarietat de mitjans, tant en el terreny econòmic com en l'Estat de Benestar, l'esforç dels individus i de la xarxa familiar per assumir les conseqüències de la voluntat normativa de l'equiparació dels sexes, l'allargament de l'esperança de vida com a real conquesta democràtica d'una societat avançada i l'extraordinària inversió en capital humà que ha suposat la millora generalitzada del nivell d'instrucció de la població espanyola, troba a la migració estrangera un complement òptim per obtenir i accelerar aquests guanys. La migració els propers decennis esdevindrà la principal aportació al creixe- 
ment de la població europea i espanyola, els canvis demogràfics associats a aquest fet no són menys que els de caràcter econòmic, polític o cultural. La immigració no és una opció, és una realitat nascuda de factors endògens de la pròpia evolució sociodemogràfica de les nostres societats que implica al seu torn nous reptes extrademogràfics.

La migració, quan el creixement com és aquest el cas, és deu principalment a l'aportació dels migrants econòmics comporta un reconeixement de la desigualtat social: els migrants estrangers, en la seva majoria estan destinats a ocupar els llocs més baixos de l'estratificació social, independentment moltes vegades del seu nivell d'instrucció i de que, com a migrants de nacionalitat estrangera poden aterrar a qualsevol de les capes de la societat, també a les més altes. El futur dels migrants, com el futur de la societat espanyola en el seu conjunt depèn de l'espai social al que se'ls destina, on la legislació juga un paper determinant des dels seus inicis. Des d'aquesta perspectiva, considerar la mobilitat social ascendent dels migrants és prioritari, però per a que aquesta es produeixi les desigualtats econòmiques no poden ser consolidades i molt menys creades per mesures de caire polític que situïn al migrant als llimbs quant als drets de ciutadania. Dit d'una altra manera, les polítiques restrictives que mantenen a hores d'ara a gairebé un milió de persones privades de drets per la seva situació d'irregularitat, no només tindran efectes nocius sobre les condicions de vida d'aquestes persones, sinó que configuren el germen d'un projecte d'estratificació etnicista nefast per al futur de la cohesió social.

Així, en contrast amb la importància creixent de les migracions internacionals i amb el paper fonamental de l'esmentada complementarietat, el risc d'exclusió social en part de la població immigrada i part de la població espanyola és preocupant. La consolidació d'un mercat de treball informal amb una forta segmentació produeix d'una banda el deteriorament general de les condicions de treball i de l'altra una competència entre els treballadors estrangers i els treballadors espanyols amb menor nivell d'instrucció i pitjor situats al mercat que pot articular-se mitjançant el discurs xenòfob. 


\section{6.}

\section{Algunas consideraciones sobre los procesos migratorios en España y en tierras valencianas*}

ANDRÉS PIQUERAS

* Este trabajo recoge en exclusividad el contenido de la sesión impartida por el profesor Andrés Piqueras, "La inmigració recent a l'Estat espanyol», dentro del Curs d'Estiu de la Universitat Jaume I, Demografia i Societat a principis del segle XXI, julio de 2003, contenido al que sólo se ha añadido alguna consideración estadística posterior. 


\section{MIGRACIÓN}

Decimos que migran las personas que dejan «su» territorio para establecerse en otro de forma duradera. Detrás de ese paso hay una enorme variedad de motivos, que van desde los más estrictamente personales y psicológicos, a los sociales o estructurales (de carácter tanto intraestatal como interestatal, o podríamos decir hoy «global»), pero también ecológicos y físicos en general. Desde el punto de vista de la tierra de origen quienes migran son emigrantes; desde el del lugar de llegada, inmigrantes.

La definición de lo que es el territorio de cada quien viene dada hoy por los Estados, en cuanto que las delimitaciones territoriales son demarcaciones políticas que se corresponden con la forma estatal de organización social, propia del sistema social de ámbito planetario en el que hoy vivimos: el capitalista. Esto posibilita, como veremos al final, que los Estados puedan atribuirse la promulgación de leyes sobre el derecho de unos y otros seres humanos a estar o no en un determinado territorio, que es apropiado por los Estados como "su» territorio; dividiendo de paso artificialmente a esos seres humanos en propios o «nacionales» y ajenos o «extranjeros». De esta forma, en el presente, una persona puede ser considerada «ilegal» por el solo hecho de estar en un territorio, contraviniendo flagrantemente el artículo 13 de la Declaración Universal de los Derechos Humanos de 1948, que reconoce el derecho de toda persona a emigrar.

Pero rastreemos, antes de recapacitar más sobre este punto, algunos de los procesos claves sobre las migraciones de los últimos siglos.

LAS MIGRACIONES COMO PROCESOS ESTRUCTURALES A LO LARGO DE LA HISTORIA

La migración ha sido una constante en la Historia de la Humanidad. Protagonizada tanto por individuos, poblaciones, como pueblos enteros en 
busca de recursos, refugio o protección, tras anhelos personales o colectivos, condiciones económicas y/o ecológicas más aceptables o lo que podíamos decir, en general, mejores oportunidades de vida.

Si nos centramos en la era moderna, cuando se forma el sistema socioeconómico capitalista, asistimos también a grandes migraciones de población que el Colectivo IOE (2000) desglosa en determinadas fases históricas según se afirma el dominio capitalista del planeta y la consiguiente jerarquización estatal mediante procesos de centralización y periferización de unos y otros Estados, y que aquí nos vamos a permitir reproducir sintéticamente:

- Migraciones colonizadoras. Fase de expansión colonial. A partir del siglo xvi la población europea se desplaza en grandes cantidades al resto de los continentes en busca de nuevos horizontes que permitieran la mejora de su calidad de vida.

Esta migración se hizo de forma colonizadora, es decir, a partir o a través de la conquista de otros pueblos y de la apropiación de sus recursos. La gente de a pie emigraba a otras tierras en calidad de colonos, o bien como «mano de obra libre». A menudo, en el caso de los hombres, a través de su enrolamiento primero como soldados que participaban de la previa conquista.

- Migraciones forzadas o de tráfico esclavista. Se calcula, por ejemplo, que entre mitad del siglo xvi y mitad del xIX entre 10 y 15 millones de africanos fueron trasladados a América como mano de obra forzada que contribuyó en alto grado al enriquecimiento de las metrópolis colonizadoras, al tiempo que dejó sin una buena parte de sus recursos humanos al continente africano. Aunque el tráfico de esclavos no se redujo al caso africano; se dio también entre la propia población europea, por ejemplo.

- Migraciones de servidumbre. Una vez prohibido formalmente el tráfico de esclavos, las necesidades de mano de obra para su empleo extensivo en las colonias se cubrieron en parte con el reclutamiento a la fuerza o bajo engaño de contingentes de población procedente sobre todo de Asia Oriental (India, China y Japón) que trabajaron en condiciones de extrema dureza, ligados a un patrón o a una compañía colonial, aunque ya retribuidos salarialmente. Este tipo de migraciones se produjo fundamentalmente en las colonias británicas a partir de 1820, y se extiende hasta comienzos del siglo xx. 
- Migraciones «libres» o de fuerza de trabajo asalariada. Desde mediados del siglo XIX se genera un mercado internacional de mano obra que provocará grandes flujos migratorios en todo el planeta. De hecho, las dimensiones migratorias habidas desde mitad de ese siglo hasta las primeras décadas del xx, no han vuelto a tener parangón. Una vez más, fue la población trabajadora europea la que más emigró (más de 50 millones entre 1846 y 1932). Los principales flujos tenían como destino las ex colonias americanas en general, aunque también destacan las entonces todavía colonias del norte de África y del sudeste asiático.

Tras la Segunda Guerra Mundial, con la ola de independencias formales de las antiguas colonias, tiene lugar su incorporación al mercado internacional de inversiones y trabajo, o lo que más tarde se perfilaría como un único Sistema Mundial. Éste se caracteriza por unas dinámicas de concentración y centralización del capital (que es lo mismo que decir, de los recursos, riquezas y, en general, oportunidades de vida): cada vez en menos manos y en menos lugares, respectivamente. Esos lugares no eran otros que las viejas metrópolis, más eEuU y Canadá.

En consecuencia, la población mundial tuvo que moverse en pos de esas (mejores) oportunidades de vida. Por primera vez en la historia moderna se invertirían los flujos migratorios mayoritarios: ahora serían de las sociedades colonizadas a las colonizadoras, fundamentalmente.

Una primera fase fue la que protagonizó la población trabajadora de las ex colonias desplazándose a sus ex metrópolis de la Europa Central. Pero también un buen porcentaje de trabajadores de la Europa periférica (mediterránea) les acompañaron en esos flujos.

En la última fase, más reciente, son los trabajadores de esas ex colonias, ya convertidas en «Sur», los que emigran al conjunto de la Unión Europea (devenida en «Norte»). Pero también la población trabajadora del «Este» de Europa (zona que pasa de «Segundo» a «Tercer» Mundo, esto es, a «Sur» también), emigra a la UE de forma creciente.

Merced a estas transformaciones, por primera vez también los países mediterráneos, entre ellos España, hasta entonces exportadores netos de mano de obra en gran escala, se hacen receptores de inmigrantes.

Con todo, en estos países las cifras absolutas y relativas de inmigración son apenas significativas, especialmente si las comparamos con las de países con larga tradición de recepción de inmigración, como los de la Europa Central, Australia, o América del Norte. 
Así, por ejemplo, mientras que en Italia, Portugal o España en 1997 el porcentaje de población inmigrada representaba respectivamente el 1\%, el 1\% y 0,9\%, en Luxemburgo, Australia o Suiza, era el 34,9\%, 21,1\% y $19 \%$ respectivamente. Y en países como Bélgica, Francia u Holanda, esos porcentajes llegaban al 8,9\%, 6,3\% y 4,4\% respectivamente.

En la actualidad en España el número de inmigrantes que tienen regularizada su situación se calcula entre un millón y millón ochocientos mil, y se estiman entre 300.000 y 600.000 más los no regularizados. Cifras que podrían suponer en torno al $5,7 \%$ de la población total española como máximo. Por otra parte, la población inmigrada regularizada es todavía casi 1,5 veces menor que la emigrada española. (En 1997, el porcentaje era 3,5 veces menor, al haber unos 610.000 inmigrantes en España, frente a 2.134.730 emigrantes, según cifras oficiales).

Lo que sí puede decirse es que con la globalización en todo el mundo se produce el gran desplazamiento Sur a Norte y Este a Norte (Norte = países que constituyeron la OCDE $=$ "Primer Mundo»; Este = Europa del Este o Bloque ex socialista en general = antiguo «Segundo Mundo»; Sur = práctica totalidad del resto del planeta $=$ "Tercer Mundo»).

Pero eso no nos puede hacer olvidar la existencia de grandes movimientos masivos también Sur-Sur (muchas veces a causa de conflictos armados, catástrofes o persecuciones políticas, pero mayoritariamente asimismo como migraciones económicas); existiendo todavía, además, otros más minoritarios Norte-Norte, entre las elites económicas e intelectuales, sobre todo, pero también entre población trabajadora en general.

Los principales flujos Sur-Sur se dan hacia los países del Golfo Pérsico, calculados en más de 7 millones de personas en la década de los 90 del siglo xx; entre países del África subsahariana, de 1 a 3 millones de personas, y también desde países andinos a países del Cono Sur, y entre países del sudeste asiático (especialmente con destino a Singapur, Malasia, Corea del Sur, Taiwán, Hong Kong o Brunei, algunos de los cuales, a su vez, también «exportan» población a otros vecinos) (ver Ruiz de Olabuénaga, 2000, para mayores detalles sobre este punto).

Con todo y pese a todas las alarmas interesadas que se vienen produciendo al respecto, ¡sólo el 0,2\% de la Humanidad está en situación de migración interestatal en la actualidad! Lo que supone entre 125 y 130 millones de personas en todo el mundo. De ellas, de 30 a 35 millones serían migrantes económicos «legales», mientras que entre 30 y 50 millones serían «ilegales», y algunos otros millones (8 a 15) estarían en dife- 
rentes estados ambiguos entre ambas categorías. Además, hay que tener en cuenta también a refugiados (en torno a los 20 millones de personas), desplazados (unos 5 millones), exiliados y acogidos (entre medio millón y 2 millones).

En realidad las migraciones intraestatales (las que se producen al interior de cada "país") son mucho mayores que las interestatales. En China hay unos 100 millones de personas en situación de inmigrantes internos en la costa Este de ese Estado, y en Brasil se producen en torno a 40 millones de migraciones hacia las zonas industriales (sólo entre estos dos colosos territoriales y demográficos suman más migraciones internas que el total de las migraciones externas o interestatales del mundo).

\section{INMigRaCión EN LA UE, EN ESPAÑa Y EN EL PAís VALENCIANO}

En Europa se concentra entre el 15 y el 20\% del total de flujos migratorios mundiales lo que, habida cuenta de las relativamente bajas cifras de emigración global mencionadas, supone un monto bastante modesto respecto al total de población mundial.

En este apartado precisaremos algunas referencias y cifras de la actual inmigración europea «occidental». En el cuadro 6.1 se ofrecen los datos absolutos y porcentuales de la población extranjera en 18 países europeos para mediados de la década de los 90, que nos indica con claridad la diferencia entre ellos respecto a la inmigración, según se refirió en el apartado anterior.

España, como país del «sur» o "periferia» europea, ha experimentado una peculiar evolución de la migración.

Desde el último tercio del siglo XIX produjo un continuo goteo emigratorio hacia los países americanos que habían sido colonias españolas (allí muchos dejaron de ser «inmigrantes" y terminaron por nacionalizarse, o nacionalizar a sus descendientes, contribuyendo a «invisibilizar» en cierta medida la emigración española). En las primeras décadas del siglo xx se añade también una emigración al norte de África, a menudo para... ¡vendimiar! (especialmente en Argelia).

Después de la contienda civil de los años 30, centenares de miles de españoles tienen que dejar el país a causa de la persecución política, dirigiéndose una vez más al norte de África o a América, y también esta vez a diferentes países europeos, especialmente a la Unión Soviética. 
Cuadro 6.1. Población extranjera en 18 países europeos, en miles de personas y porcentajes, 1996

\begin{tabular}{lrrr}
\hline PAís & POBLACIÓN & EXTRANJEROS & $\%$ \\
\hline Luxemburgo & 401 & 132,5 & 33,0 \\
Suiza & 6.969 & $1.291,8$ & 18,5 \\
Bélgica & 10.101 & 920,6 & 9,1 \\
Alemania & 81.338 & $6.990,6$ & 8,6 \\
Austria & 8.015 & 517,7 & 6,5 \\
Francia & 57.779 & $3.596,6$ & 6,2 \\
Suecia & 8.745 & 507,5 & 5,8 \\
Holanda & 15.342 & 779,8 & 5,1 \\
Noruega & 4.325 & 164,0 & 3,8 \\
Dinamarca & 5.197 & 189,0 & 3,6 \\
Reino Unido & 58.293 & $2.035,1$ & 3,5 \\
Irlanda & 3.569 & 91,0 & 2,5 \\
Islandia & 265 & 4,7 & 1,8 \\
Portugal & 9.892 & 157,1 & 1,6 \\
Grecia & 149,1 & 1,4 \\
Italia & 10.410 & 649,1 & 1,1 \\
España & 57.139 & 430,4 & 1,1 \\
Finlandia & 39.121 & 55,6 & 1,1 \\
\hline Total & 5.078 & $18.662,2$ & 4,9 \\
\hline EEE & 381.979 & $17.414,9$ & 4,6 \\
\hline
\end{tabular}

Fuente: Colectivo IOE (1999).

Más tarde, a mitad de siglo, un relativamente alto porcentaje de la población española se ve forzado a emigrar según el ciclo agrícola francés, así como también para dirigirse a los centros industriales, primero, y más tarde a los núcleos de servicios, de Alemania, Bélgica, Suiza, Gran Bretaña o la misma Francia, entre los principales Estados de destino. Para principios de los años 70, más de 2 millones de españoles llegaron a estar emigrados, siendo las remesas de dinero que remitían al país, junto con los ingresos del turismo, los factores que permitieron paliar en parte el déficit crónico de la balanza comercial española. Hasta que esa tendencia emigratoria se modifica, como dijimos, a partir de finales de esa década y, especialmente, de los últimos años 80 del siglo xx.

Sigamos ahora la evolución de la inmigración desde mediados del siglo xx, en el cuadro 6.2. Los porcentajes son muy bajos, a pesar de la progresión geométrica de la inmigración: en el año 2000 se había multiplicado por 4,7 respecto a 1981, y las cifras del 2003 suponen casi 38 veces más que 40 años antes y algo más del triple que hace sólo cuatro años. Pero es que se partía prácticamente de nada, en un país que, como se ha 
dicho, fue durante el siglo xx fundamentalmente exportador de mano de obra.

En cualquier caso, las cifras de inmigración resultarían todavía más "suavizadas» para la mayoría de la población española si tenemos en cuenta que hasta el año 1995 la población inmigrante provenía mayoritariamente de países de lo que hoy es la Unión Europea. En ese año, 1995, las cifras de inmigrantes comunitarios y extracomunitarios se igualan por primera vez, y es sólo a final de esa década cuando comienzan a ser superiores para la inmigración del Sur.

A pesar de estos datos, la población extranjera de la uE pasa desapercibida como inmigrante. Pocas personas piensan en ella cuando consideran la inmigración. Pero si no fuera por su presencia las cifras de ésta habrían sido nimias para España.

En su mayoría, en contra también de lo que se piensa, la inmigración comunitaria es población económicamente activa, que cotiza a la Seguridad Social, como muestra el cuadro 6.3 para el caso del País Valenciano.

Cuadro 6.2. Evolución de la población extranjera residente en España y en el País Valenciano

\begin{tabular}{lcccc}
\hline AÑO & $\begin{array}{c}\text { POBLACIÓN } \\
\text { INMIGRADA }\end{array}$ & $\begin{array}{c}\text { \% DEL TOTAL DE } \\
\text { LA POBLACIÓN }\end{array}$ & $\begin{array}{c}\text { \% INMIGRANTES DE LA UE } \\
\text { RESPECTO TOTAL INMIGRACIÓN }\end{array}$ & $\begin{array}{c}\text { POBLACIÓN INMIGRADA } \\
\text { EN EL PAÍS VALENCIANO }\end{array}$ \\
\hline 1960 & $\begin{array}{l}64.660 \\
148.400\end{array}$ & 0,2 & 75,7 & $7.000^{*}$ \\
1970 & 198.042 & & 70,4 & \\
1985 & 242.000 & 0,6 & 59,3 & $35.000^{*}$ \\
1990 & 278.000 & & 59,0 & \\
1995 & 500.000 & 1,2 & 50,0 & $70.000^{*}$ \\
1999 & 801.329 & 2,0 & & 80.594 \\
2000 & 938.783 & 2,7 & & $150.000^{*}$ \\
2001 & 1.572 .017 & 3,8 & 25,9 & 217.673 \\
2003 & $2.500 .000 *$ & 5,8 & & $265.000^{*}$ \\
\hline
\end{tabular}

* Población aproximada (población extranjera residente en el País Valenciano estimada a partir de su porcentaje en el año 2001 respecto al total estatal).

Fuente: elaboración propia a partir de datos del CeIM (2002), del Ministerio del Interior y del INE.

Cuadro 6.3. Afiliación de extranjeros comunitarios a la Seguridad Social en el País Valenciano por porcentajes respecto al total de extranjeros afiliados, 2002

\begin{tabular}{cccc}
\hline Alicante & Castellón & Valencia & Total País Valenciano \\
44,1 & 15,3 & 21,5 & 31,4 \\
\hline
\end{tabular}

Fuente: C. Gómez Gil (2003). 
Veamos cómo se distribuye a principios del siglo XXI el total de la población inmigrante por Comunidades Autónomas, y también por comarcas dentro del País Valenciano.

Cuadro 6.4. Residentes extranjeros en España por Comunidades Autónomas, 2001

\begin{tabular}{|c|c|c|c|c|c|}
\hline \multirow[b]{2}{*}{ CC.AA. } & \multicolumn{2}{|c|}{ POBLACIÓN TOTAL } & \multicolumn{2}{|c|}{ RESIDENTES EXTRANJEROS } & \multirow{2}{*}{$\frac{\mathrm{RE} / \mathrm{PT} \times 100}{\mathrm{DENSIDAD}}$} \\
\hline & NÚMERO & $\%$ & NÚMERO & $\%$ & \\
\hline Andalucía & 7.357 .558 & 18,0 & 178.130 & 11,3 & 2,4 \\
\hline Aragón & 1.204 .215 & 2,9 & 38.314 & 2,4 & 3,2 \\
\hline Asturias & 1.062 .998 & 2,6 & 13.254 & 0,8 & 1,2 \\
\hline Baleares & 841.669 & 2,1 & 68.826 & 4,4 & 8,2 \\
\hline Canarias & 1.694 .477 & 4,1 & 97.950 & 6,2 & 5,8 \\
\hline Cantabria & 535.131 & 1,3 & 8.661 & 0,5 & 1,6 \\
\hline Castilla-La Mancha & 1.760 .516 & 4,3 & 40.668 & 2,6 & 2,3 \\
\hline Castilla-León & 2.456 .474 & 6,0 & 37.674 & 2,4 & 1,5 \\
\hline Cataluña & 6.343 .110 & 15,5 & 310.307 & 19,7 & 4,9 \\
\hline C. Valenciana & 4.162 .776 & 10,2 & 217.673 & 13,8 & 5,2 \\
\hline Extremadura & 1.058 .503 & 2,6 & 11.271 & 0,7 & 1,1 \\
\hline Galicia & 2.695 .880 & 6,6 & 35.152 & 2,2 & 1,3 \\
\hline Madrid & 5.423 .384 & 13,3 & 366.099 & 23,3 & 6,7 \\
\hline Murcia & 1.197 .646 & 2,9 & 69.556 & 4,4 & 5,8 \\
\hline Navarra & 555.829 & 1,3 & 24.274 & 1,5 & 4,3 \\
\hline País Vasco & 2.082 .587 & 5,1 & 31.168 & 1,9 & 1,5 \\
\hline La Rioja & 276.702 & 0,7 & 12.865 & 0,8 & 4,6 \\
\hline Ceuta & 71.505 & 0,2 & 3.246 & 0,2 & 4,5 \\
\hline Melilla & 66.411 & 0,2 & 6.929 & 0,4 & 10,4 \\
\hline Total & 40.847 .371 & 100,0 & 1.572 .017 & 100,0 & 3,8 \\
\hline
\end{tabular}

Fuente: CEIM (2001).

Cuadro 6.5. Residentes extranjeros en las comarcas valencianas, 2001

\begin{tabular}{lrrc}
\hline & RESIDENTES EXTRANJEROS & POBLACIÓN TOTAL & \% RESIDENTES EXTRANJEROS \\
\hline Els Ports & 63 & 5.184 & 1,22 \\
L'Alt Maestrat & 107 & 8.114 & 1,32 \\
El Baix Maestrat & 5.058 & 66.947 & 7,56 \\
L'Alcalatén & 215 & 15.028 & 1,43 \\
La Plana Alta & 9.238 & 202.154 & 4,57 \\
La Plana Baixa & 3.350 & 161.075 & 2,08 \\
L'Alt Palància & 250 & 22.546 & 1,11 \\
L'Alt Millars & 55 & 4.125 & 1,33 \\
El Racó d'Ademús & 33 & 2.864 & 1,15 \\
Els Serrans & 212 & 17.185 & 1,23 \\
El Camp de Túria & 2.192 & 102.689 & 2,13 \\
Camp de Morvedre & 1.231 & 74.149 & 1,66 \\
L'Horta Nord & 3.057 & 183.672 & 1,66 \\
L'Horta Oest & 3.928 & 292.985 & 1,34 \\
València & 22.765 & 746.612 & 3,05 \\
L'Horta Sud & 1.737 & 141.326 & 1,23
\end{tabular}


Cuadro 6.5. Residentes extranjeros en las comarcas valencianas, 2001 (continuación)

\begin{tabular}{lccc}
\hline & RESIDENTES EXTRANJEROS & POBLACIÓN TOTAL & \% RESIDENTES EXTRANJEROS \\
\hline Plana d'Utiel-Requena & 679 & 38.187 & 1,78 \\
La Foia de Bunyol & 626 & 34.182 & 1,83 \\
La Vall d'Aiora & 59 & 10.384 & 1,83 \\
La Ribera Alta & 2.747 & 199.458 & 1,38 \\
La Ribera Baixa & 1.634 & 73.843 & 2,21 \\
Canal de Navarrés & 805 & 16.579 & 4,86 \\
La Costera & 1.305 & 66.796 & 1,95 \\
La Vall d'Albaida & 1.665 & 83.071 & 2,00 \\
La Safor & 4.910 & 143.188 & 3,43 \\
El Comtat & 408 & 25.929 & 1,57 \\
L'Alcoià & 1.225 & 105.240 & 1,16 \\
L'Alt Vinalopó & 600 & 48.872 & 1,23 \\
El Vinalopó Mitjà & 2.171 & 151.492 & 1,43 \\
La Marina Alta & 41.336 & 145.100 & 28,49 \\
La Marina Baixa & 26.703 & 138.171 & 19,33 \\
L'Alacantí & 13.867 & 388.364 & 3,57 \\
El Baix Vinalopó & 5.957 & 243.011 & 2,45 \\
El Baix Segura & 40.278 & 244.086 & 16,50 \\
\hline Total & 200.466 & 4.202 .608 & 4,77
\end{tabular}

Fuente: Universidad Politécnica de Valencia. Informe sobre la inmigración valenciana, 2003.

Ahora desglosaremos un poco más, según algunos de los principales países de procedencia de la inmigración valenciana.

Cuadro 6.6. Residentes extranjeros en el País Valenciano, por países de procedencia. Principales contingentes, 2001

\begin{tabular}{|c|c|c|c|c|c|}
\hline Europa & 116.957 & América & 62.246 & África & 31.034 \\
\hline Reino Unido & 27.638 & Colombia & 21.585 & Marruecos & 18.655 \\
\hline Alemania & 19.399 & Ecuador & 21.142 & Argelia & 6.910 \\
\hline Rumanía & 11.204 & Argentina & 5.869 & Senegal & 1.206 \\
\hline Francia & 9.082 & Cuba & 2.241 & Resto (19) & 4.263 \\
\hline Países Bajos & 6.242 & Brasil & 1.925 & & \\
\hline Bélgica & 5.686 & Perú & 1.263 & & \\
\hline Ucrania & 4.916 & Uruguay & 1.188 & Asia & 7.202 \\
\hline Bulgaria & 4.915 & Bolivia & 1.182 & China & 4.346 \\
\hline Italia & 4.650 & EEUU & 1.166 & Resto (17) & 2.856 \\
\hline Suiza & 4.391 & Venezuela & 1.125 & & \\
\hline Rusia & 2.913 & Chile & 1.089 & & \\
\hline Noruega & 2.841 & Resto (14) & 2.471 & Oceanía & 176 \\
\hline Suecia & 2.348 & & & & \\
\hline Portugal & 1.483 & & & & \\
\hline Polonia & 1.467 & & & & \\
\hline Lituania & 1.291 & & & & \\
\hline Resto (18) & 6.491 & & & & \\
\hline
\end{tabular}

Fuente: CEIM, 2002. 
Una de las consideraciones que hay que hacer sobre las cifras de inmigración es que varían mucho según la fuente que se tome, lo que indica la dificultad de su cuantificación veraz y, en general, de su estudio riguroso y completo, al haberse constituido en un fenómeno estructural al proceso de globalización capitalista, que atraviesa el conjunto de dinámicas socioeconómicas concomitantes al mismo, a menudo con vertientes sumergidas y otras lindantes o inmersas en la economía gris y/o en la directamente delictiva, lo que le connota con fuertes rasgos de invisibilidad. De ahí también, que en este trabajo hayamos preferido alternar o combinar las cifras de unas y otras fuentes, con el fin, por una parte, de mostrar la disparidad de medidas al respecto de la "cuantificación" de la inmigración y, por otra, ofrecer algún término de fiabilidad entre unas y otras.

Por lo que respecta al País Valenciano, podemos ver, a pesar de todo, que los residentes de la UE siguen teniendo una enorme importancia en el total de la población inmigrante, especialmente en Alicante, provincia que además de albergar al 65\% del total de la inmigración valenciana empadronada, presenta un $60 \%$ de población inmigrante comunitaria dentro de aquélla. Esta población comunitaria, como hemos visto, lejos de estar integrada mayoritariamente por jubilados o retirados en busca de climas cálidos, como sugiere el tópico, incluye en gran medida a la población que desempeña una actividad laboral.

Por su parte, si en Valencia representa el 18\%, en Castellón esta población comunitaria alcanza un también significativo 17\% del total de población inmigrada. Pero veamos estos guarismos en el cuadro 6.7, así como la composición de la población extranjera en el País Valenciano por provincias y comarcas, en los cuadros 6.8 y 6.9 respectivamente. Los totales provinciales de población valenciana a 1 de enero de 2002 eran los siguientes: Alicante: 1.576.980 personas; Castellón: 506.480; y Valencia: 2.286.128. Por ello, el total del País Valenciano se elevaba a 4.369 .588 personas.

A partir de los cuadros 6.5 a 6.8 podemos observar una perceptible diferencia provincial en cuanto a la importancia del peso de la inmigración y respecto al origen de la misma.

Según un estudio de la Universidad Politécnica de Valencia, en el año 2001 algo menos de 4 de cada cien habitantes empadronados en la provincia de Castellón (3,8\%) eran extranjeros: 18.336 personas. Pero sólo El Baix Maestrat sobrepasaba la ratio de 5 extranjeros por cada 100 habitantes. La Plana Alta (con 4,5\%) y la Baixa (2\%), que son las que siguen a esta comarca, están en porcentajes muy modestos. Ninguna de las restantes comarcas 
Cuadro 6.7. Extranjeros empadronados en el País Valenciano por provincias (01-01-02) y porcentajes respecto a la población total y al total de población inmigrada

\begin{tabular}{lcccc}
\hline & ALICANTE & CASTELLÓN & VALENCIA & TOTAL \\
\hline Extranjeros empadronados & 170.240 & 26.629 & 68.024 & 264.893 \\
\hline \% población total & 10,7 & 5,3 & 2,9 & 6 \\
\% total población inmigrada & 65 & 10 & 25 & 100 \\
\% UE & 60 & 17 & 18 & 45 \\
\hline
\end{tabular}

Fuente: C. Gómez Gil (2003).

Cuadro 6.8. Porcentaje de inmigrantes por provincias según procedencia (entre paréntesis cifras absolutas), 2001

\begin{tabular}{llll}
\hline \multicolumn{1}{c}{ ALICANTE } & \multicolumn{1}{c}{ CASTELLÓN } & \multicolumn{1}{c}{ VALENCIA } \\
\hline 65,5 UE (86.765) & 26,4 Europa no com. (4.843) & 29,5 Sudamérica (14.639) \\
11,8 Europa no com. (15.582) & 24,5 Magreb (4.493) & 21,3 UE (10.546) \\
10,2 Sudamérica (13.557) & 22,7 UE (4.164) & 15,5 Europa no com. (7.705) \\
& 18,2 Sudamérica (3.329) & 14,0 Magreb (6.936) \\
\hline
\end{tabular}

Fuente: Universidad Politécnica de Valencia. Informe sobre la inmigración valenciana 2003.

castellonenses llega al 1,5\% de población inmigrada empadronada. Porcentajes similares muestran las comarcas de la provincia de Valencia, muy lejos, como las de Castellón, de los porcentajes de comarcas alicantinas como La Marina Alta (28,5\%), La Marina Baixa (19,3\%) o El Baix Segura $(16,5 \%)$. En las dos primeras de estas últimas, sobre todo, debido a la gran concentración de población de la Unión Europea, como se ha indicado.

Digno de mención en el caso de Castellón es el significativo incremento de población de la Europa oriental experimentado en el último lustro, sobre todo debido a la inmigración rumana, que en esta provincia supera ya a la magrebí y presenta la mayor concentración de toda España.

Cabe señalar, además, que Castellón es foco de atracción de inmigrantes de otras provincias, como lo muestra el hecho de que hay más inmigrantes dados de alta en la seguridad social que empadronados. Pero detengámonos un poco más en esta provincia.

\section{INMIGRACIÓN EN CASTELLÓN}

En 2003 la procedencia mayoritaria de la población inmigrante en Castellón es rumana y marroquí, seguida de cerca por la de la UE. Por lo que respecta a la correlación entre hombres y mujeres, se ha ido igualando 
con el tiempo hacia una nivelación, con la incorporación de cada vez más mujeres, especialmente gracias a la oferta doméstica (limpieza y cuidado de terceras personas); pero también a su inserción en el sector agrícola (especialmente en el almacenaje, aunque no únicamente) y en la hostelería. En la actualidad las mujeres representan en torno al 45,5\% de la inmigración castellonense.

Desglosando por orígenes cabe decir que se evidencian importantes diferencias en este sentido. Así, por ejemplo, la inmigración africana es mayoritariamente masculina: $71 \%$ del total. Las mujeres, en cambio, son mayoría en la inmigración americana: 57,2\%.

El porcentaje de población rumana con respecto al conjunto de población inmigrante es especialmente elevado en algunas comarcas. Este es el caso del Alt Maestrat, donde hay varias localidades en que sobrepasa el 50\% de la población inmigrante, y en algunas como Catí, 1lega a suponer casi el 90\% de la misma. Se dan los casos de Torre d'En Besora y Vilar de Canes en que toda la población extranjera empadronada es rumana (100\% de la inmigración). La propia Albocàsser, capital de la comarca, presentaba el año 2002 un 61,1\% de población rumana sobre el total de inmigrantes.

Hace tiempo que el fenómeno de la concentración por origen de la inmigración se ha estudiado bajo el modelo analítico de redes y su formulación de la acumulación de ventajas que tal concentración por origen supone para las personas inmigradas (aumento del capital social, relacional, de oportunidades laborales, amparo familiar, defensa idiomática y cultural, protección de grupo en general, etc.). Son estas las razones que provocan que en algunas comarcas, como es el caso de la Plana Alta, no exista una pauta de origen generalizada en la concentración de la población inmigrada.

Así, por ejemplo, en Cabanes o en Coves de Vinromà predominaba ampliamente en el año 2003 la población norteafricana (56,5\% del total de inmigrantes, en el primer caso; 47 de las 54 personas extranjeras residentes en la última localidad, 87\%). Lo mismo ocurre en la Pobla de Tornesa (60,7\% del total). Mientras que en Borriol, de un total de 67 extranjeros residentes en el año 2000, la mayoría, 30, eran de la UE (44,7\% del total). En Sant Joan de Moró, por su parte, en 2003, 164 del total de 215 personas extranjeras, procedían de América Latina (76,2\%).

Algo parecido se puede decir para el Alto Palancia, comarca que en 2003 presenta varias localidades con mayoría de población extranjera latino- 
americana, como es el caso de algunas de las más importantes: Jérica (68,7\% del total inmigrantes) o Caudiel (57,1\%); incluyendo la propia capital, Segorbe $(73,6 \%)$. Esa población latinoamericana es fundamentalmente colombiana (en Segorbe la población de Colombia representa ella sola el 42,2\% del total de la población inmigrada).

Los mayores porcentajes de población inmigrada se dan en el norte costero de la provincia, seguidos, aunque con proporciones más modestas, por el área industrial-azulejera. Con la salvedad de la capital, que presenta una concentración media entre una y otra zona, tal como muestra el cuadro 6.10.

Cuadro 6.9. Inmigrantes por origen en la provincia de Castellón

\begin{tabular}{lccc}
\hline ORIGEN & N. ${ }^{0}$ HABITANTES & \% INMIGRACIÓN SEGÚN ORIGEN & \% TOTAL \\
\hline Rumanía & 15.347 & 83,2 extranjeros europeos no comunitarios & 35,0 \\
Marruecos & 6.880 & 73,5 inmigración africana & 15,7 \\
Unión Europea & 5.454 & & 12,5 \\
Colombia & 3.522 & 42,6 inmigración americana & 8,0 \\
\hline
\end{tabular}

Fuente: IVE 2003.

Cuadro 6.10. Concentración mayoritaria de la población inmigrante en la provincia de Castellón

\begin{tabular}{lclc}
\hline LOCALIDAD & \% INMIGRANTES & LOCALIDAD & \% INMIGRANTES \\
\hline Norte costero & & Cluster industrial azulejero & \\
Peníscola & 22,2 & Castelló & 9,2 \\
Alcalà de Xivert & 19,5 & Borriana & 5,9 \\
Orpesa & 17,8 & Vila-real & 4,6 \\
Benicàssim & 14,3 & Onda & 4,1 \\
Torreblanca & 12,2 & La Vall d'Uixó & 3,5 \\
Vinaròs & 11,0 & L'Alcora & 2,7 \\
Benicarló & 10,6 & & \\
\hline
\end{tabular}

Fuente: Anuario Social de España. Indicadores Sociales Municipales. Año 2004. La Caixa.

LIMITACIÓN DE LA FUERZA DE TRABAJO MUNDIAL Y UTILIZACIÓN DE LA MISMA MEDIANTE SU EXTRANJERIZACIÓN. EL CASO DEL AGRO VALENCIANO

Las barreras a la movilidad de la fuerza de trabajo están sujetas a aperturas parciales o temporales según requerimientos de mano de obra de unas u otras economías (en la actualidad sobre todo de las centrales). Esas aperturas están destinadas a cubrir: 
- Empleos de complementariedad con los de la población local (aquellos que en su mayoría esta última rechaza debido a las pretensiones de promoción y ascenso social y profesional que imperan en las sociedades centrales). Esta inmigración suele estar sujeta a limitaciones de temporalidad, de tipo estacional (según ciclos de trabajo agrícola, sobre todo); y basada en la no cualificación (o empleada para puestos que no requieren cualificación alguna).

La población que llega bajo estas condiciones está sometida a circunstancias de vida y laborales extremadamente duras, padeciendo además situaciones de invisibilidad social o guetización.

- En menor medida, empleos de competencia con los de la población local. a) Sea también en los escalones más bajos de la escala socioprofesional (con aquella población local que no pudo realizar la prometida ascensión social); b) Sea en empleos más cualificados o técnicos, para paliar la falta de profesionales locales para cubrir los mismos, o para disminuir el costo de su mano de obra (los profesionales inmigrados realizarán el mismo trabajo por menor salario, presionando a la baja el salario general).

La situación de competencia suele estar reservada por lo general para la inmigración legalizada y con mayor estabilidad. Esta mano de obra es buscada también para paliar en parte la escasa tasa de reproducción de las sociedades centrales.

Hemos de tener en cuenta asimismo, a tenor de lo dicho, que la permisividad o "vista gorda» ante el paso de inmigración ilegalizada, tiene como objetivo aumentar las posibilidades de explotación de esa fuerza de trabajo (ya que su indefensión es total y no se atreverá a plantear reivindicaciones laborales), y disminuir en general, por tanto, el poder de negociación de la población trabajadora local (ya que siempre habrá alguien que estará dispuesto a aceptar condiciones peores de trabajo). Esto está siendo fuente de conflictos entre el conjunto de la población trabajadora (que queda dividida a conveniencia en "nacional» $\mathrm{y}$ «extranjera», dificultando su unión frente a los contratadores).

El modelo agrícola español, y en concreto el valenciano, es hoy el de la agro-industria. Esto quiere decir que se vertebra en torno a una agricultura altamente tecnificada, con también altos niveles de productividad. Requiere asimismo un muy elevado consumo de energía, a través del uso de gran variedad de insumos y combustibles fósiles; además de 
precisar del trabajo discontinuo de gran cantidad de mano de obra, con una explotación extensiva de una buena parte de la misma (muchas horas y jornadas de trabajo por poco salario). Este modelo da como resultado, por consiguiente, una sobreexplotación tanto de recursos, como de seres humanos.

Es precisamente esa alta demanda discontinua de mano de obra, según unos u otros periodos de recolección, lo que ha impedido que pueda ser cubierta por el grupo familiar, incluso con la ayuda de eventuales jornaleros, y se haya tenido que recurrir a la fuerza de trabajo inmigrante.

El eminente carácter exportador del agro valenciano implica una alta competencia, con un elevado costo de los factores de producción. El empresario agrícola valenciano, como el mediano agricultor, encuentran la única vía de reducción de costos en el factor humano (es decir, en la reducción real de los salarios). La altísima desregulación que presenta este sector, por otra parte, permite que se den muy pocos contratos, por lo que la mano de obra está sujeta a una amplia informalidad, teniéndose que adecuar casi cada día a los requerimientos de la producción, sin obligaciones laborales por parte de los empresarios o contratadores.

Los inmigrantes se insertan en ese «nicho» laboral, llevándose la peor parte del trabajo en condiciones muy duras que además, al perpetuarse, les separan de la población autóctona, contribuyendo a su visibilidad negativa, como "sucios», «brutos", "poco capaces» para otras cosas, etc. (ver para todo ello, por ejemplo, Torres, 2002, García Borrego y Pedreño, 2002, y Pedreño, 2002).

Por eso, entre las opciones de esa población inmigrada, está el contemplar el trabajo agrícola sólo como un primer paso, mientras encuentra algo mejor, generalmente en la construcción y en la hostelería, a donde se suele dirigir después. De esta manera tenemos que, si el sector primario les ofrece una fuente relativamente «fácil» de entrada, para empezar a trabajar, la «legalidad», o el contrato laboral, casi nunca lo consiguen ahí, sino en todo caso, después, en el sector servicios-construcción (sin que esto quiera decir que no haya en este último sector también un alto grado de informalidad laboral).

En el cuadro 6.11 se reflejan algunas de estas características del mercado de trabajo español, en tanto que se compara con la distribución sectorial de la mano de obra inmigrante en otros países de la UE, donde su peso en la industria (y hemos de pensar que en la economía estable en general) es ostensiblemente mayor. 
Cuadro 6.11. Distribución sectorial de los trabajadores inmigrantes en la UE, 2000

\begin{tabular}{lcrrrrrrr}
\hline & & & & & SERVICIO & TOTAL & RESTO \\
& AGRICUltura & CONSTRUCCIÓN & HOSTELERÍA & COMERCIO & DOMÉSTICO & RAMAS & INDUSTRIA & SERVICIOS \\
\hline Alemania & 1,5 & 9,0 & 10,6 & 12,5 & 0,6 & 34,2 & 33,7 & 32,1 \\
Austria & 1,4 & 12,0 & 11,6 & 12,5 & 0,8 & 38,3 & 27,5 & 34,2 \\
Bélgica & 1,7 & 8,0 & 6,9 & 15,3 & 0,8 & 32,7 & 23,6 & 43,7 \\
Dinamarca & 3,1 & 2,4 & 7,1 & 12,8 & - & 25,4 & 19,5 & 55,1 \\
España & 7,8 & 9,4 & 14,9 & 12,6 & 18,0 & 62,7 & 10,9 & 26,4 \\
Finlandia & 4,3 & 3,6 & 10,2 & 14,3 & 0,5 & 32,9 & 16,8 & 50,3 \\
Francia & 3,0 & 17,3 & 6,9 & 11,9 & 7,1 & 46,2 & 19,6 & 34,2 \\
Grecia & 3,4 & 27,2 & 8,6 & 10,9 & 19,6 & 69,7 & 18,4 & 11,9 \\
Irlanda & 2,5 & 7,6 & 12,3 & 8,8 & 1,4 & 32,6 & 18,8 & 48,6 \\
Italia & 5,4 & 9,4 & 8,5 & 11,0 & 10,9 & 45,2 & 30,3 & 24,5 \\
Luxemburgo & 0,8 & 15,6 & 8,0 & 13,1 & 4,0 & 41,5 & 10,3 & 48,0 \\
Países Bajos & 2,4 & 4,3 & 6,1 & 13,9 & 0,2 & 26,9 & 24,4 & 48,7 \\
Portugal & 2,7 & 25,2 & 9,6 & 10,0 & 6,8 & 54,3 & 17,3 & 28,4 \\
Reino Unido & 0,3 & 5,1 & 9,9 & 11,6 & 1,6 & 28,5 & 13,8 & 57,7 \\
Suecia & 1,8 & 1,9 & 8,5 & 12,7 & - & 24,9 & 21,4 & 53,7 \\
\hline
\end{tabular}

Fuente: CEIM (2002).

La segregación ocupacional, por la que se deparan ciertos tipos y formas de trabajo a los inmigrantes (obviamente los menos queridos y considerados por la población local), está abriendo también el camino a la creciente afluencia de mujeres en la inmigración, hasta el punto de casi equilibrar ya el flujo masculino, situándose entre el 45 y 47\% del total de la población inmigrante, según las fuentes.

Su inserción se realiza en el servicio doméstico, en alguna de sus múltiples modalidades, pero también en las labores agrícolas, especialmente, las realizadas a cubierto (almacenaje, embalaje, etc.). Y por supuesto, no hay que descuidar su extraexplotación como objetos de sexo, a través de la prostitución, donde muchas de ellas van a parar de forma forzada, sea explícitamente obligadas o sea mediante engaños.

\section{FORMAS DE TRABAJO IRREGULAR DE LOS INMIGRANTES}

Entre las principales formas de trabajo irregular a que se ve sometida la población inmigrante, podemos destacar, siguiendo a Ambrosini (1998), las siguientes: 
Trabajo irregular dependiente

- Eventual y estacional. Propio de la utilización intensiva de mano de obra. Implica una elevada movilidad (a veces desde el propio país de origen). Ej. típico: jornaleros.

- Semicontinuado. Según necesidades periódicas de la demanda o encargos específicos. Ej. típico: construcción, transporte, limpieza, hosteleríaturismo.

- Estable o continuado. Características semejantes a las de la economía formal, pero sin contrato formalizado: a) De ocupación empresarial (sector terciario, artesanado, construcción). b) Sector doméstico (= relaciones de patronage: explotación con protección).

Trabajo irregular independiente

- Autoempleo de refugio. Marginal, desempeñado sin permisos. A veces semimendicidad, disfrazada apenas de intercambio comercial. A veces, como subcomercialización de productos. Ej. típico: venta ambulante.

- Incorporación ascensional. Ocupación en empresas «étnicas», dirigidas por familias, o propia empresa con socios «ficticios».

Trabajo forzoso

- Prestaciones de trabajo dependiente que se obliga a realizar a inmigrantes, a menudo por sus propios conciudadanos o grupos étnicos, como pago de las deudas contraídas para emigrar. También mediante retención por la fuerza de personas que son engañadas en su lugar de origen. Ej. típico: cierta prostitución femenina. Pero también el trabajo en empresas "étnicas», clandestinas.

En el cuadro 6.12 presentamos datos (parciales y a buen seguro poco exactos) sobre trabajadores inmigrantes con y sin permisos laborales durante la última mitad de la década de los 90 en el País Valenciano.

Cuadro 6.12. Trabajadores extranjeros

\begin{tabular}{rcc}
\hline AÑO & PERMISOS CONCEDIDOS EN EL AÑO & TRABAJADORES CON PERMISO \\
\hline 1994 & 4.669 & 6.415 \\
1995 & 5.450 & 7.157 \\
1996 & 7.516 & 9.012 \\
1997 & 4.572 & 9.362 \\
1998 & 6.513 & 12.041 \\
1999 & 6.365 & 11.942 \\
\hline
\end{tabular}

Fuente: IVE. La Comunidad Valenciana en cifras. 
Figura 6.1. Evolución anual de los permisos de trabajo concedidos y del número de trabajadores extranjeros con permiso de trabajo en el País Valenciano

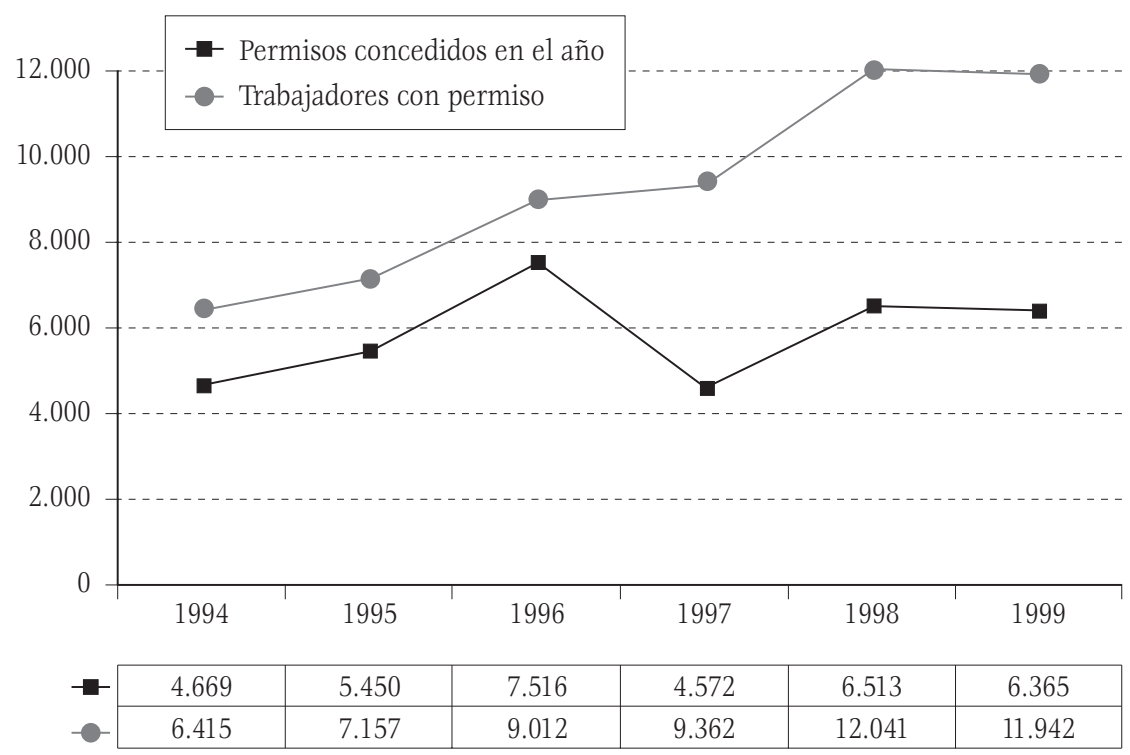

Fuente: IVE. La Comunidad Valenciana en cifras.

\section{INVERSIÓN DEL FLUJO MIGRATORIO Y SU REFLEJO JURÍDICO}

La inversión migratoria, tan característica del Estado español, va a tener sus correlatos institucionales y jurídicos. Comenzando por la pronta transformación del Instituto Español de la Emigración, en Dirección General de Migraciones, tras la transición democrática.

En el año 1985 se intenta por primera vez «regularizar» (conocer, regular y supervisar) la situación de la población inmigrada en España. Se elabora, para ello, la Ley Orgánica 7/85, «de derechos y libertades de los extranjeros en España», mejor conocida como "Ley de Extranjería». A partir de su promulgación, las personas inmigrantes dejan de tener derechos por sí mismas, para pasar a depender de criterios administrativos. Las «Leyes de Extranjería» que empezaron a multiplicarse por todos los países de la UE, consagran un principio de división de los seres humanos en «legales» e «ilegales» (haciéndose equivalente estos últimos a «delincuentes», sólo por su presencia física en un territorio). 
Tres procesos de regularización de extranjeros, se efectúan con posterioridad en España, en 1991, 1996 y 2000. En 1996 se redacta un nuevo reglamento que modifica la Ley de Extranjería, mientras que en 2000 se promulga en realidad una nueva Ley de Extranjería (la 8/2000), con un notable endurecimiento del trato a la condición de inmigrante.

Pero en general todo el entramado jurídico español es deudor de unos mismos presupuestos comunes a la "política» migratoria española y europea, que relatamos a continuación (ver, para lo que sigue, Ruiz de Olabuénaga, 2000, y en general para consideraciones jurídicas sobre la inmigración, De Lucas y Peña, 2001, y De Lucas y Torres, 2002):

- Derecho de propiedad de la ciudadanía, que se arroga para sí el Estado. Excluye el derecho de las personas a inmigrar y a residir en el país de su elección. Primero son los «nacionales»; segundo los extranjeros «legales», y por último los «ilegales».

- Inevitabilidad de la inmigración debido a la globalización. Justifica el argumento de que «si se dejaran las puertas abiertas habría una "invasión"», sin cuestionarse cómo se produce la dinámica globalizadora en sí o cómo podría modificarse, ni atender a los procesos alternativos a la emigración que las propias poblaciones emprenden en todo el mundo.

- La «tolerancia» de la inmigración debe estar ligada a la contribución al bienestar de los «nacionales». Asunción derivada de una concepción utilitarista, instrumental, del inmigrante, en su consideración exclusiva como fuerza de trabajo utilizada a conveniencia.

- La sociedad nacional posee una capacidad muy limitada de absorción de la población inmigrante. «Razonamiento» que parece conducir indefectiblemente a la fijación de cuotas o cupos en función de la situación socioeconómica del país. Desconsidera abiertamente las previsiones sociodemográficas para las poblaciones europeas.

- Concibe la inmigración como una iniciativa que parte exclusivamente de los inmigrantes, debido a su situación de debilidad, y no de la demanda de la propia sociedad de una mano de obra flexible e indefensa.

- Se aduce la necesaria sumisión a los Pactos y Tratados europeos (sobre todo Schengen y Maastricht). Con ello se cierra el círculo vicioso, ofreciendo la imagen de la irremediabilidad de lo que se hace. 
En consecuencia, en toda la UE se proclaman como inevitables ciertas medidas para combatir la "presión migratoria», tales como:

- Implantación de visados.

- Incremento del control policial fronterizo e intrafronterizo.

- Endurecimiento del derecho de asilo y de la posibilidad de regularización de la situación de los inmigrantes.

- Nuevos procedimientos para el rechazo en fronteras.

- Sistemas anuales de contingentes o cuotas, en función del mercado laboral.

- Legalización de las expulsiones in situ, con desamparo de las personas.

- Firma de nuevos acuerdos y tratados internacionales para la prevención de flujos.

Todo lo cual viene a reforzar, especialmente en los países de recepción, la división de los seres humanos en «nacionales» $\mathrm{y}$ "no nacionales» o «extranjeros», reforzando la noción y el sentimiento de «invasión» en los primeros con los más mínimos incrementos en la llegada de estos últimos.

Por otra parte, la situación, tanto de partida como de llegada, la inserción social, la formación, los motivos y sueños de la población inmigrante son tan variados como las personas. Buscar el estereotipo de inmigrante, no forma parte sino de una interpretación racista de los procesos migratorios y de la intervención social y política respecto de los mismos.

Tampoco existen criterios nítidos u objetivos para determinar quién es inmigrante. Por un lado muchas personas dejaron de serlo al nacionalizarse (pero siguen siendo percibidas como «extranjeras» por una buena parte de la población). Por el contrario, hay inmigrantes que no son considerados extranjeros (como algunas poblaciones blancas de las ex colonias europeas, cuando terminaron fijando su residencia en la antigua metrópoli).

¿Qué pasa, por otra parte, con los hijos de inmigrantes residentes de largo tiempo?, ¿y con sus nietos? ¿Continúan siendo «inmigrantes»?, ¿siguen siendo «extranjeros» en alguna medida para la población local?

Todas estas consideraciones, en suma, complejizan bastante la sencilla definición que sobre la migración dimos al principio. A lo largo de estas líneas hemos tenido ocasión de ver que esa consideración o al menos «visibilidad» de un ser humano como «inmigrante», está muy directamente 
relacionada a su condición de "pobre». Los extranjeros «ricos», de la UE, o de otros países considerados «desarrollados», no son percibidos como «inmigrantes».

Lo que, como afirma el Colectivo IOE (con un vasto y rico trabajo realizado sobre la inmigración), hace que esta concepción de «inmigrante» esté compuesta de al menos dos términos: extranjería + pobreza. Dando lugar a seres humanos por carencia, "no sujetos», al margen de la ciudadanía, listos para ser sobre-explotados. 


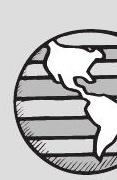

7.

Extranjeros en el País Valencià

(una aproximación imperfecta a la inmigración)

RAFAel Viruela MartíneZ

CONCHA DOMINGO PÉREZ 
En el País Valencià, la presencia de residentes extranjeros ha tenido desde hace tiempo una relativa importancia, puesto que muchos ciudadanos europeos escogieron localidades costeras como lugar de residencia. Pero en los últimos años ha llegado de forma súbita un gran contingente de inmigrantes de distintas nacionalidades que está modificando anteriores esquemas migratorios y la estructura social de muchos municipios valencianos, tanto en las áreas urbanas del litoral como en el ámbito rural del interior donde hasta hace poco la presencia de inmigrantes era escasa.

Para el análisis de la inmigración disponemos de múltiples fuentes estadísticas. Las más utilizadas son las que aportan información sobre el stock de extranjeros en un momento dado, la serie anual que elabora el Ministerio del Interior y el Censo de Población (el último de 2001) y el Padrón de Habitantes (con datos más recientes a 1 de enero de 2003) del Instituto Nacional de Estadística. Este organismo, como el Institut Valencià d'Estadística, también se encarga de la Estadística de Variaciones Residenciales, que recoge las altas y las bajas que se producen en cada municipio y, a diferencia de las anteriores, no cuenta individuos sino flujos migratorios, con la particularidad de que una misma persona puede generar varios registros. A estas fuentes hay que añadir las estadísticas de trabajadores extranjeros afiliados a la Seguridad Social en alta laboral, lo que permite estudiar la participación de los inmigrantes en el mercado de trabajo.

También contamos con un gran número de investigaciones y publicaciones de estudiosos y especialistas de varias disciplinas académicas. Entre los primeros trabajos destaca el realizado por un grupo de geógrafos a principios de la década de 1990 (Gozálvez, 1993 y 1995). Más reciente es el elaborado por investigadores de diferente formación ${ }^{1}$ y que, pese a su elevado

1 Se trata del proyecto Inmigración en la Comunidad Valenciana. Situación actual y paradigmas políticos de integración, dirigido por el profesor Antonio Ariño (Departamento de Sociología de la Universitat de València) entre septiembre de 2002 y marzo de 2003 para la Conselleria de Benestar Social de la Generalitat Valenciana. 
interés social, todavía no se ha publicado. Gracias a estas y otras investigaciones, conocemos numerosas facetas y características de la inmigración e incluso ha comenzado a desarrollarse una imprescindible reflexión teórica. En el ámbito del País Valencià, varias revistas le han dedicado números monográficos: Arxius, «Inmigració i societat» (2001); Cuadernos de Geografía: «La dinámica inmigratoria, perspectivas sociogeográficas» (2002); Cuadernos Electrónicos de Filosofia del Derecho: «La integración social de los inmigrantes en la Comunidad Valenciana. Modelos de políticas públicas» (2002). ${ }^{2}$

El subtítulo de este capítulo se justifica por el hecho de que, pese al esfuerzo que se ha venido realizando en los últimos años, todavía no somos capaces de responder a preguntas tan simples como cuántos y qué inmigrantes tenemos o cuáles son sus condiciones de vida y de trabajo, sobre todo por la elevada proporción de personas en situación irregular. La desregularización del mercado de trabajo crea el ambiente propicio para la atracción de inmigrantes irregulares, que a su vez refuerzan la economía sumergida. Es, pues, una «aproximación imperfecta a la inmigración» en la que se expone el rápido aumento de la población extranjera, la diversidad de procedencias, la distribución en el territorio valenciano y su participación en el mercado de trabajo.

\section{Crecimiento acelerado de la inMigración en el País Valencià}

La inmigración es un fenómeno muy reciente en España, pues se circunscribe fundamentalmente a la década de 1990, con un aumento espectacular en el cambio de siglo. Según las estadísticas del Ministerio del Interior, el País Valencià ha pasado de tener 25.000 extranjeros, a principios de la década de 1980, a 50.000, diez años después. La cifra se ha duplicado en el último lustro, contabilizándose un total de 138.421, a 31 de diciembre de 2002, el 10\% de los que residen en España. El aumento de los últimos años es consecuencia de las dos grandes operaciones de regularización decididas por el gobierno (en 2000 y 2001), que han sacado a la luz a personas que llevaban aquí varios años sin estar registradas. Las cifras del Ministerio quedan muy por debajo de las que aporta el Instituto Nacional de Esta-

\footnotetext{
2 A estas publicaciones hay que añadir otros monográficos en revistas de ámbito estatal, como los que han dedicado Economistas: "España, país de inmigración» (2003), Papeles de Economía: «Inmigración en España» (2003) y Economía Exterior: «Inmigración, desarrollo, paz» (2004).
} 
dística. Así, en noviembre de 2001 se censaron más de 200.000 extranjeros, pocos meses después, el Padrón de enero de 2002 aumentaba la cifra a 300.000 y el del año siguiente a más de 400.000. A este ritmo de crecimiento, en el momento actual los extranjeros empadronados en municipios valencianos podrían superar el medio millón.

Las diferencias entre una y otra fuente de información se deben al hecho de que los extranjeros registrados por el Ministerio son inmigrantes con papeles en regla, es decir, con permiso de residencia y la mayoría trabajadores con permiso de trabajo y afiliación a la Seguridad Social, mientras que en el Padrón aparecen los extranjeros, en situación legal o ilegal, que se registran en las oficinas municipales de empadronamiento, motivo por el que esta fuente se aproxima más a la realidad (Villán, 2002), aunque también hay sobreinscripciones y subinscripciones. Así, se sabe de inmigrantes que han conseguido inscribir a familiares y amigos que todavía no se habían trasladado a España (Arango, 2003; Leguina, 2004) y también se conocen casos de ciudadanos comunitarios, con una elevada representación en el País Valencià, que optan por no registrarse para evitar complicaciones fiscales o porque no lo consideran indispensable, entre otras cosas porque a ellos no se les exige permiso de trabajo o porque son jubilados y no trabajan (Arango, 2002).

Lo cierto es que en las estadísticas del Ministerio del Interior no se incluye a los inmigrantes en situación irregular. Algunos autores (Cachón, 2003; Ugarte, 2004) comparan los datos del Ministerio con la cifra de extranjeros empadronados para estimar el volumen (la diferencia entre una y otra magnitud) de los residentes en situación irregular. Así las cosas, a principios de 2003 habría en España tantos extranjeros en situación irregular como legal, alrededor de 1.300.000, y en el País Valencià tendríamos 138.000 residentes legales frente a 275.000 «sin papeles».

Estimaciones más cautas de ong sitúan el número de indocumentados entre 600.000 y 800.000 en toda España a finales de 2003 (Ugarte, 2004). En cualquier caso, los sucesivos, y no tan extraordinarios, procesos de regularización demuestran que la inmigración irregular ha sido muy importante. Nada menos que 600.000 personas presentaron solicitud en las regularizaciones de 2000 y 2001. En el País Valencià, la mayor parte de los inmigrantes procedentes de países con bajos niveles de renta han estado en la irregularidad en algún momento de su proceso migratorio y, como es sabido, todavía hay una bolsa importante de personas «sin papeles», ya que ningún programa de regularización es capaz de poner el contador a cero, 
porque no todos los inmigrantes reúnen los requisitos que les exigen para legalizar su situación y, además, continúan llegando de forma clandestina y como falsos turistas. Asimismo, no pocos extranjeros recaen en la irregularidad porque no consiguen renovar a tiempo los permisos de trabajo y residencia.

En los últimos años, España ha sido el estado que más ha contribuido al aumento de la inmigración en la Unión Europea (Sopemi, 2003) y, sin duda, el País Valencià ha jugado un papel importante en este sentido ya que se ha convertido en uno de los destinos más importantes (aquí reside el 15\% de los extranjeros empadronados el 1 de enero de 2003) sólo por detrás de Madrid (22\%) y Cataluña (20\%). Si aceptamos como válidos los resultados del Padrón, los 413.760 extranjeros residentes equivalen al 9,2\% de la población valenciana, una proporción nada despreciable y semejante a la de muchos países europeos: Alemania, Austria o Bélgica.

Entre las causas que contribuyen a explicar el rápido aumento de la inmigración se pueden citar diversos factores que empujan a miles de personas a abandonar su país: el escaso poder adquisitivo de los salarios, el empobrecimiento, la depauperación, la frustración y la falta de confianza en el futuro, el mal gobierno y el caos político, la violencia, etc. Pero, al margen de los factores de expulsión, como país de inmigración, nos interesa destacar los factores de atracción, esto es, los motivos por los que se han decidido por el País Valencià, que no deben ser sustancialmente distintos a los que se pueden citar para el caso de otras regiones españolas o de otros países que han visto aumentar rápidamente el número de inmigrantes. En cualquier caso, la mayor parte de los desplazados son personas que pueden hacerlo, ya que disponen de recursos y/o del apoyo de redes sociales tan necesarios para el éxito del proyecto migratorio.

Muchos migrantes eligen España o el País Valencià porque han fracasado en otras opciones de su preferencia: Estados Unidos para los latinoamericanos, Francia para los magrebíes, Alemania para los europeos del Este. Las restrictivas políticas inmigratorias adoptadas en los tradicionales países de destino provocan una reorientación geográfica de los flujos hacia otros países, como España, donde tampoco se permite la inmigración irregular, aunque socialmente se acepta la economía sumergida y en cierta forma se tolera la explotación laboral de extranjeros "sin papeles». En efecto, si hasta hace poco los ecuatorianos se dirigían a Estados Unidos, ahora la mayoría emigra a España. La dificultad para entrar en aquel país por el aumento de la vigilancia de la frontera ha convertido el destino español en 
la alternativa más segura y económica, a pesar de la distancia (González, 2004), con la ventaja añadida del idioma. Los rumanos y otros europeos del Este, sobre todo los de ascendencia germana (los Aussiedler), han acudido en masa a Alemania, pero los cambios introducidos en la legislación alemana en materia de naturalización les han empujado hacia otros países: Francia, Italia, España, Portugal, etc. (Viruela, 2002).

Es evidente que los inmigrantes vienen porque tienen posibilidades de encontrar trabajo, ya sea en la economía formal o en la informal, en sectores (agricultura, ganadería o construcción, por ejemplo) que han ido abandonando los españoles, cuyos esquemas laborales han cambiado mucho en los últimos años. Además, la incorporación de la mujer al mercado de trabajo y el progresivo envejecimiento demográfico han convertido a muchos hogares en lugar de trabajo de la mano de obra extranjera.

Son pocos los emigrantes que salen sin tener alguna información o conocimiento sobre su destino y las posibilidades de trabajo y alojamiento, que les proporcionan otros emigrantes y los medios de comunicación. España se ve como un país donde es fácil entrar, residir y trabajar sin necesidad de documentos, aunque sea en trabajos marginales y donde, más pronto o más tarde, se puede legalizar la situación aprovechando un proceso extraordinario de regularización. ${ }^{3}$ Las anécdotas y la experiencia de los emigrantes que regresan a casa hacen soñar a quienes esperan poder emigrar, sobre todo cuando escasean las alternativas de trabajo en el lugar de origen, donde la emigración es muy visible: se reforman las casas, los hogares se equipan con todo tipo de electrodomésticos, el agricultor compra un tractor o la familia invierte en un pequeño negocio. A partir de los primeros que salieron, la emigración se convierte en una especie de enfermedad contagiosa, una especie de reacción en cadena (González, 2004), que incluso es animada por las autoridades locales (Potot, 2002).

\section{DIVERSIDAD DE PROCEDENCIAS: CAMBIOS EN EL PAISAJE MIGRATORIO}

El número de residentes extranjeros aumenta rápidamente y, al mismo tiempo, se han diversificado las áreas de procedencia, destacando la presencia cada vez mayor de inmigrantes no comunitarios que desde el

${ }^{3}$ Una probabilidad que el anterior gobierno dio por finalizada en 2001 y que ahora (a finales de 2004) puede aplicarse de nuevo por motivo de arraigo laboral. 
año 2000 superan a los ciudadanos de la Unión Europea (la de 15 miembros). El predominio de éstos ha sido una constante en nuestra corta historia inmigratoria, pero los protagonistas del fuerte incremento que se registra durante el cambio de siglo han sido inmigrantes de "terceros países». Tanto es así que, como ha destacado Lorenzo Cachón (2003) para el conjunto español, nos encontramos con una «nueva inmigración». Nueva por las regiones de origen y el nivel de desarrollo de éstas, nueva por su diversidad cultural y religiosa, nueva por los rasgos fenotípicos y nueva por las motivaciones económico-laborales.

El País Valencià se ha convertido en pocos años en un destino preferente para miles de emigrantes de países respecto a los cuales se han ahondado las diferencias. No obstante, conviene destacar el aumento del número de extranjeros procedentes de países ricos, sobre todo de la Unión Europea (figura 7.1) que, con el 36,6\% de los extranjeros empadronados a 1 de enero de 2003, siguen siendo el colectivo predominante. Se trata fundamentalmente de británicos y alemanes, la mayoría pensionistas y jubilados de renta alta o medio-alta, que han escogido algunas localidades costeras como lugar de residencia, aunque no faltan los trabajadores, como comprobaremos más adelante. En la fecha citada, algo más de 50.000 inmigrantes procedían del continente africano y la participación más elevada correspondía a Marruecos. Pero, sin duda, la característica más destacada de la inmigración que hemos recibido en los últimos años ha sido el extraordinario aumento de la presencia latinoamericana, correspondiendo los porcentajes mayores a Ecuador y Colombia. También llama la atención la incorporación a la corriente inmigratoria de ciudadanos del resto de Europa, la mayoría venidos de países poscomunistas (Rumania, Bulgaria, etc.). Un flujo con el que hasta hace poco no manteníamos ningún vínculo, a diferencia del magrebí, por su proximidad geográfica, el latinoamericano, por motivos histórico-culturales o el de la Europa comunitaria, por cercanía y tradición de turismo residencial.

Los cambios en la composición de la población extranjera están relacionados con los recientes procesos de regularización de 2000 y 2001 que, entre otros colectivos, han beneficiado sobre todo a ecuatorianos, marroquíes, colombianos, rumanos y búlgaros (Ministerio del Interior) y son resultado de la gestión política de la inmigración llevada a cabo por el gobierno del Partido Popular, cuyo objetivo ha sido reequilibrar el peso que había alcanzado el colectivo marroquí con inmigrantes latinoamericanos y europeos de países del Este (Izquierdo y Martínez, 2003). 
Figura 7.1. Extranjeros residentes en el País Valencià

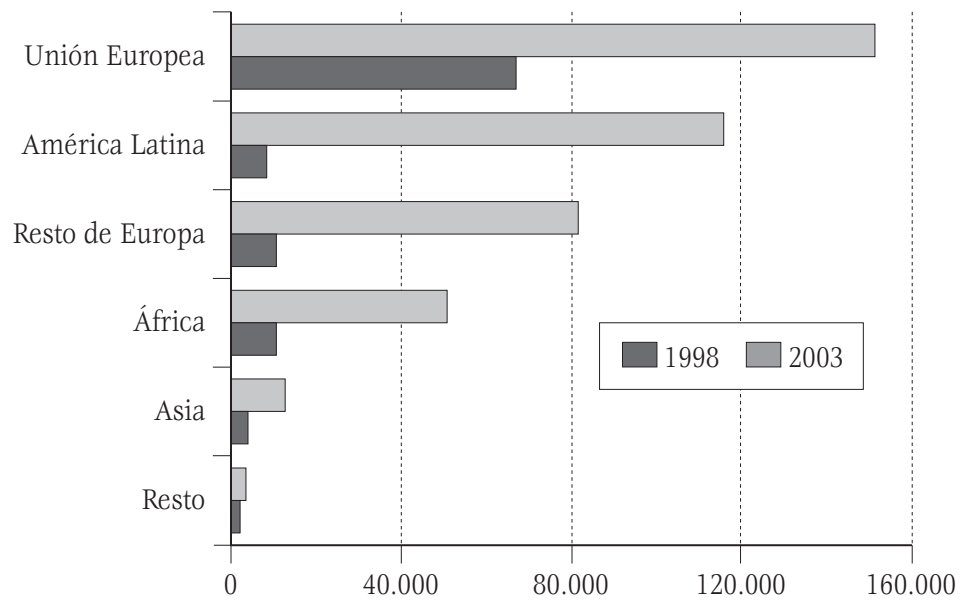

Cuadro 7.1. Principales países de procedencia de la población extranjera en 2003 en el País Valencià

\begin{tabular}{lrr}
\hline PAís & 1998 & 2003 \\
\hline Reino Unido & 24.591 & 57.707 \\
Ecuador & 189 & 43.104 \\
Alemania & 15.547 & 35.695 \\
Colombia & 768 & 35.116 \\
Marruecos & 6.041 & 30.078 \\
Rumania & 379 & 27.950 \\
Argentina & 2.409 & 14.542 \\
Francia & 8.193 & 14.109 \\
Holanda & 6.165 & 11.789 \\
Bulgaria & 212 & 11.629 \\
Argelia & 1.889 & 11.208 \\
Los 11 & 66.383 & 120.833 \\
\hline Total & 100.554 & 413.760
\end{tabular}

Fuente: INE, para los datos de 2003, e IVE, explotación especial de la información padronal para 1998. Elaboración propia.

Así pues, pocas cosas son como eran hace apenas un lustro (figura 7.1, cuadro 7.1). Entonces era muy difícil prever el rápido aumento de algunas nacionalidades como la colombiana, la ecuatoriana o la rumana, por ejemplo.

En 1998, ingleses y alemanes sumaban el 40\% de los extranjeros residentes y otros ciudadanos comunitarios el 27\%. En 2003, los británicos son el grupo con más efectivos (poco menos de 58.000), pero ya hay más de 
43.000 ecuatorianos, el número de colombianos es similar al de alemanes y es muy poca la diferencia numérica entre rumanos y marroquíes.

Entre los inmigrantes de la Unión Europea y los de terceros países existen diferencias en la estructura por sexo y edad, ${ }^{4}$ socioculturales, en las motivaciones de su desplazamiento, etc. En general, entre los ciudadanos comunitarios hay una elevada representación de personas mayores ya retiradas del mercado de trabajo, con una proporción equilibrada de hombres y mujeres. Entre los no comunitarios predominan las personas jóvenes y adultas, con importantes diferencias en la relación de sexos según la región de procedencia de los inmigrantes. En unos casos hay mayor proporción de mujeres, como ocurre con muchos colectivos latinoamericanos. En otros, la migración ha estado protagonizada por los varones, caso de los marroquíes y otros emigrantes africanos. En cambio, los extranjeros de otras procedencias muestran un cierto equilibrio entre sexos y, además, una elevada proporción de jóvenes menores de quince años, como se observa en algunos colectivos de reciente incorporación, como el rumano, el colombiano y el ecuatoriano, características propias de una migración familiar, de matrimonios y parejas jóvenes con hijos que han elegido el País Valencià y España como lugares de instalación permanente o duradera.

Obviamente, los desafíos que la inmigración plantea a la sociedad de acogida son distintos según el número, las características y la heterogeneidad de la población extranjera, que es muy diferente de unas comarcas a otras e incluso de unos municipios a otros.

\section{DISTRIBUCIÓN GEOGRÁFICA: CONCENTRACIÓN Y DISPERSIÓN}

Según los resultados del Padrón de 2003, la mayor parte de los extranjeros reside en tres grandes áreas: en el litoral sur, sobre todo en las comarcas de la Marina y el Baix Segura, que reúnen el 44\% del total (más del $50 \%$ si se añade l'Alacantí), en València y su entorno (l'Horta), con cerca del 20\%, y en el litoral norte, con el 10\%, la mayoría en la Plana.

La concentración espacial es más evidente a escala municipal (figuras 7.2 y 7.3) ya que casi la mitad de los extranjeros reside en nueve municipios: Calp, Xàbia, Benidorm, Elx, Orihuela y Torrevieja, además de las tres capitales de provincia.

\footnotetext{
${ }^{4}$ Estos aspectos han sido analizados con detalle por la profesora Concha Domingo (2002).
} 
Figura 7.2. (izquierda) Variación absoluta de los extranjeros empadronados entre 1998 y 2003

Figura 7.3. (derecha) Proporción de extranjeros sobre la población total en 2003

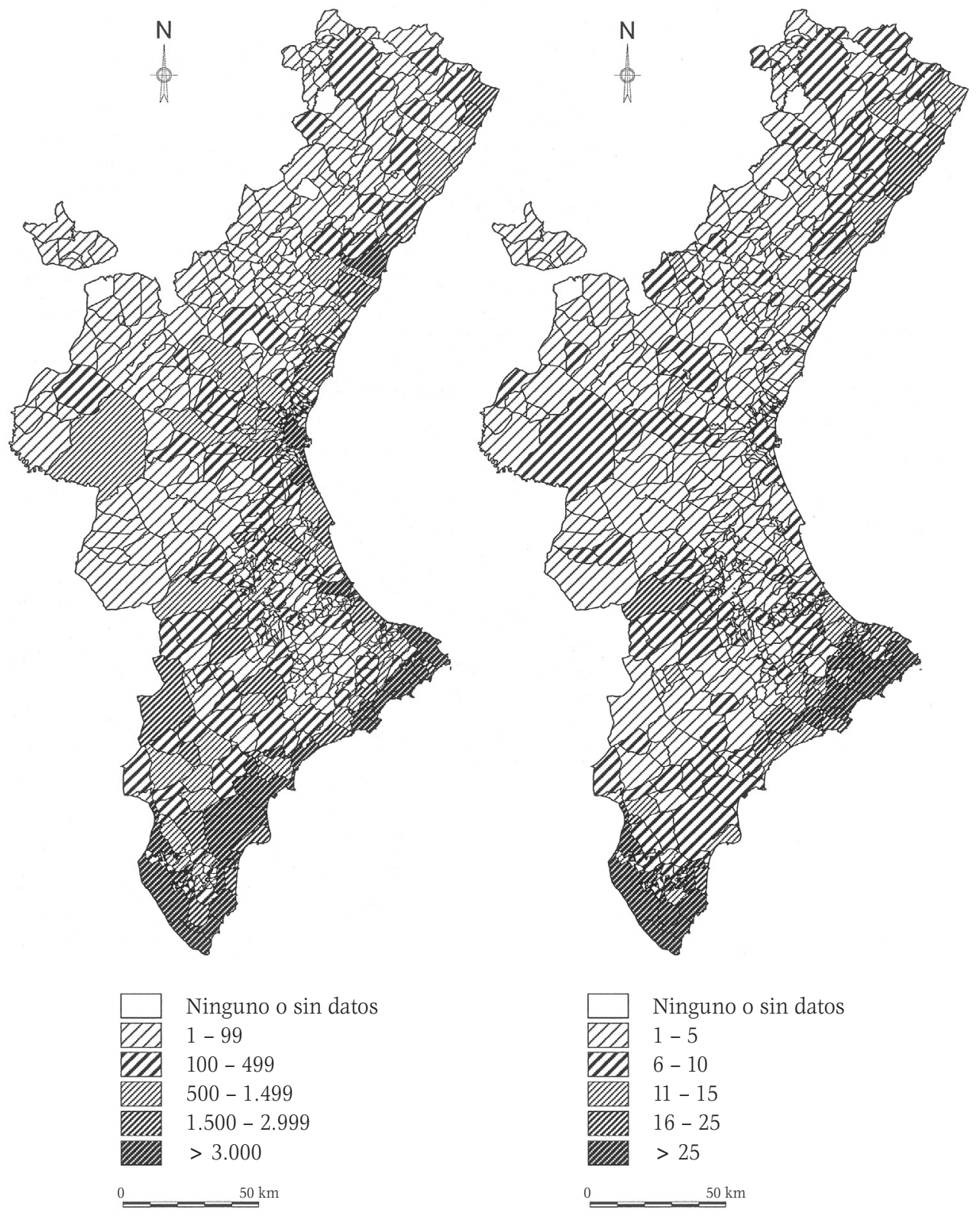


Figura 7.4. (izquierda) Variación absoluta de los extranjeros empadronados entre 1998 y 2003

Figura 7.5. (derecha) Proporción de extranjeros sobre la población total en 2003

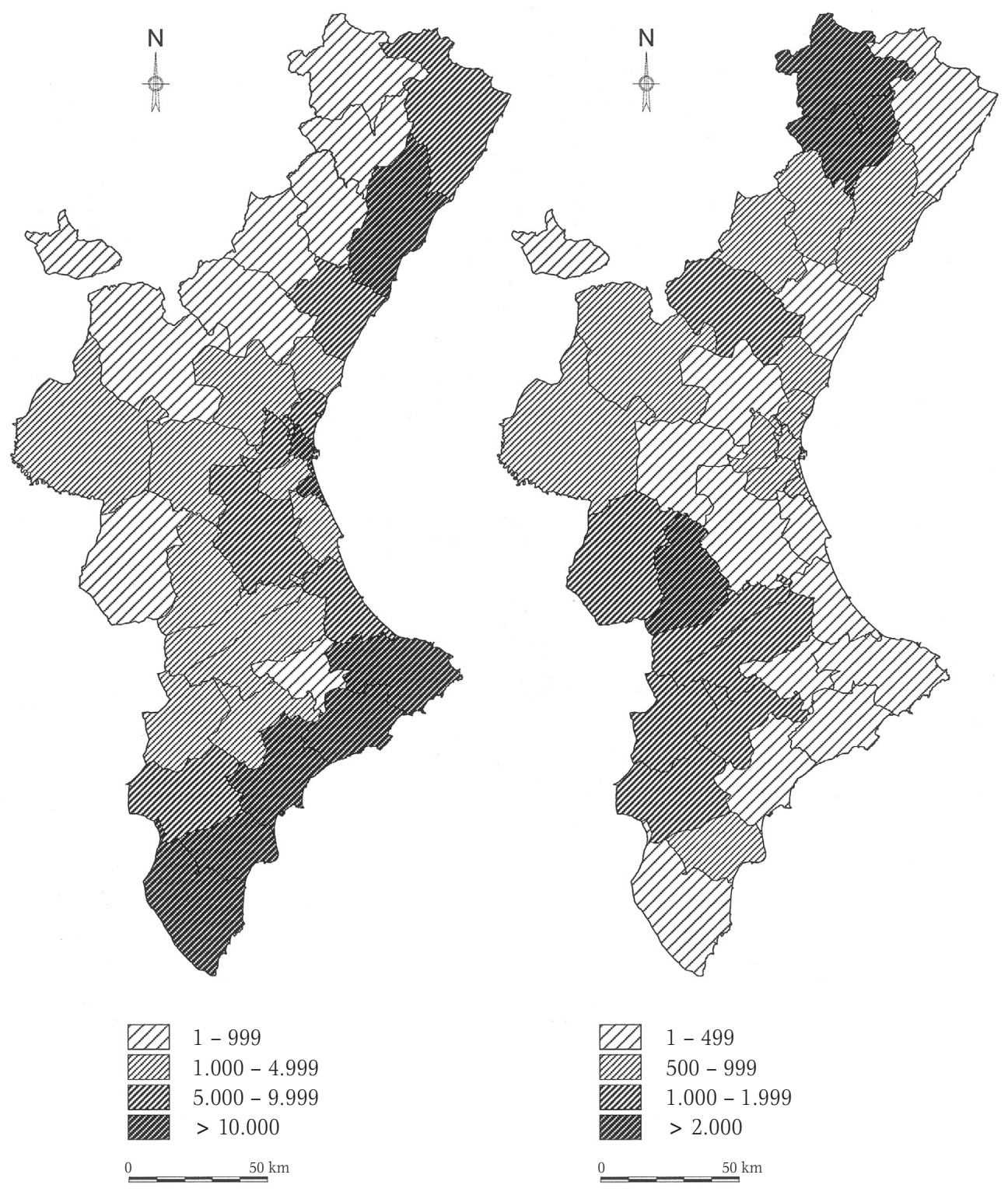


En el litoral meridional hay muchos municipios en los que la población foránea supera el 25\% del Censo e incluso el 50\%, como ocurre por ejemplo en varias localidades de la Marina. En cambio, como se puede ver en los mapas, hacia el interior disminuyen los efectivos y su importancia relativa; sin embargo, como hemos señalado en trabajos anteriores (Viruela y Domingo, 2001, véase también Esparcia, 2002), aquí el fenómeno inmigratorio tiene cada vez más importancia.

La distribución geográfica, que coincide a grandes rasgos con la del conjunto de la población valenciana, se relaciona con la concentración de la actividad económica en las comarcas litorales, las más dinámicas, urbanizadas e industrializadas y las que disponen de una amplia oferta de empleo estacional en la agricultura intensiva y citrícola y en actividades relacionadas con el turismo. Por ello no resulta sorprendente que, entre 1998 y 2003 (cuadro 7.2, figura 7.4), el mayor aumento del número de residentes extranjeros se haya registrado en la costa.

En efecto, el 46\% de los recién llegados se ha establecido en el Baix Segura, la ciudad de València y la Marina Alta y, como en todas partes, la mayoría lo ha hecho en los dos últimos años. Otras comarcas con gran afluencia inmigratoria son l'Alacantí, la Marina Baixa y la Plana Alta. No obstante, conviene destacar que en términos relativos (figura 7.5) el incremento ha sido mayor en municipios del interior, sobre todo en los de els Ports, l'Alt Maestrat y la Canal de Navarrés, debido en la mayor parte de los casos a que contaban con muy pocos efectivos el primer año.

En definitiva, el fenómeno inmigratorio registra un crecimiento rápido en todo el territorio valenciano, llegando incluso a las áreas del interior. En este ámbito, como ha observado Javier Esparcia (2002), los extranjeros sienten cierto atractivo por las comarcas rurales intermedias, las de agricultura de secano que cuentan con cierta actividad industrial y un nivel de servicios relativamente bueno, sobre todo en los núcleos que, por su tamaño demográfico, ofrecen mayores oportunidades de empleo. Tal es el caso de Morella, en els Ports; Segorbe, en el Alto Palancia; Lliria, en el Camp del Túria; Xiva, en la Hoya de Buñol; Villena, en el Alto Vinalopó; Ontinyent, en la Vall d'Albaida o de Requena y Utiel.

La difusión de la corriente inmigratoria por áreas rurales obedece, entre otros factores, a la escasez de mano de obra en el sector agropecuario y en otras actividades a resultas de la intensa despoblación que vienen padeciendo desde hace décadas y al consiguiente envejecimiento demográfico, a la expansión de la actividad industrial por comarcas del interior o al 
Cuadro 7.2. Extranjeros residentes en el País Valencià, en 1998, 2001 y 2003

\begin{tabular}{|c|c|c|c|c|c|c|c|c|}
\hline \multirow[b]{2}{*}{ COMARCAS } & \multicolumn{3}{|c|}{ EFECTIVOS } & \multicolumn{2}{|c|}{ Variación 2003-1998 } & \multicolumn{3}{|c|}{ N. ${ }^{0}$ de orden } \\
\hline & 1998 & 2001 & 2003 & EFECTIVOS & $\%$ & 1998 & 2001 & 2003 \\
\hline Els Ports & 7 & 63 & 240 & 233 & $3.328,6$ & 34 & 31 & 31 \\
\hline L'Alt Maestrat & 11 & 107 & 379 & 368 & $3.345,4$ & 33 & 30 & 30 \\
\hline El Baix Maestrat & 2.348 & 5.058 & 8.994 & 6.646 & 283,0 & 7 & 8 & 10 \\
\hline L'Alcalatén & 85 & 215 & 570 & 485 & 570,6 & 26 & 28 & 29 \\
\hline La Plana Alta & 2.672 & 9.238 & 24.029 & 21.357 & 799,3 & 6 & 6 & 6 \\
\hline La Plana Baixa & 1.649 & 3.350 & 8.595 & 6.946 & 421,2 & 10 & 11 & 11 \\
\hline El Alto Palancia & 56 & 250 & 867 & 811 & $1.448,2$ & 29 & 27 & 26 \\
\hline L'Alt Millars & 14 & 55 & 115 & 101 & 721,4 & 32 & 33 & 33 \\
\hline Castelló & 6.842 & 18.336 & 43.789 & 36.947 & 540,0 & & & \\
\hline EL Rincón de Ademúz & 18 & 41 & 63 & 45 & 250,0 & 31 & 34 & 34 \\
\hline Los Serranos & 59 & 212 & 615 & 556 & 942,4 & 28 & 29 & 28 \\
\hline EL Camp del Túria & 945 & 2.192 & 4.773 & 3.828 & 405,1 & 14 & 14 & 17 \\
\hline El Camp de Morvedre & 452 & 1.231 & 2.780 & 2.328 & 515,0 & 19 & 20 & 21 \\
\hline L'Horta Nord & 1.108 & 3.057 & 7.493 & 6.385 & 576,3 & 13 & 12 & 12 \\
\hline L'Horta Oest & 1.456 & 3.928 & 10.828 & 9.372 & 643,7 & 11 & 10 & 9 \\
\hline València & 8.035 & 22.765 & 57.505 & 49.470 & 615,7 & 4 & 4 & 3 \\
\hline L'Horta Sud & 688 & 1.737 & 4.864 & 4.176 & 607,0 & 16 & 17 & 15 \\
\hline La Plana de Utiel-Requena & 162 & 679 & 1.627 & 1.465 & 904,3 & 24 & 23 & 24 \\
\hline Hoya de Bunyol & 284 & 626 & 1.508 & 1.224 & 431,0 & 21 & 24 & 25 \\
\hline El Valle de Ayora & 16 & 59 & 177 & 161 & $1.006,2$ & 30 & 32 & 32 \\
\hline La Ribera Alta & 1.164 & 2.747 & 6.982 & 5.818 & 499,8 & 12 & 13 & 14 \\
\hline La Ribera Baixa & 921 & 1.634 & 3.082 & 2.161 & 234,6 & 15 & 18 & 20 \\
\hline La Canal de Navarrés & 72 & 805 & 1.715 & 1.643 & $2.281,9$ & 27 & 22 & 23 \\
\hline La Costera & 257 & 1.306 & 3.544 & 3.287 & $1.279,0$ & 22 & 19 & 19 \\
\hline La Vall d'Albaida & 379 & 1.665 & 4.823 & 4.444 & $1.172,6$ & 18 & 16 & 16 \\
\hline La Safor & 1.960 & 4.910 & 11.709 & 9.749 & 497,4 & 9 & 9 & 8 \\
\hline València & 17.976 & 49.594 & 124.088 & 106.112 & 590,3 & & & \\
\hline El Comtat & 236 & 408 & 795 & 559 & 236,9 & 23 & 26 & 27 \\
\hline L'Alcoià & 328 & 1.225 & 4.081 & 3.753 & $1.144,2$ & 20 & 21 & 18 \\
\hline L'Alt Vinalopó & 156 & 600 & 2.263 & 2.107 & $1.350,6$ & 25 & 25 & 22 \\
\hline El Vinalopó Mitjà & 566 & 2.171 & 7.093 & 6.527 & $1.153,2$ & 17 & 15 & 13 \\
\hline La Marina Alta & 29.557 & 41.336 & 61.159 & 31.602 & 106,9 & 1 & 1 & 2 \\
\hline La Marina Baixa & 18.018 & 26.734 & 40.728 & 22.710 & 126,0 & 2 & 3 & 4 \\
\hline L'Alacantí & 7.336 & 13.867 & 32.982 & 25.646 & 349,6 & 5 & 5 & 5 \\
\hline El Baix Vinalopó & 1.849 & 5.957 & 15.201 & 13.352 & 722,1 & 8 & 7 & 7 \\
\hline El Baix Segura & 17.680 & 40.278 & 81.581 & 63.901 & 361,4 & 3 & 2 & 1 \\
\hline Alacant & 75.726 & 132.576 & 245.883 & 107.157 & 141,5 & & & \\
\hline País Valencià & 100.544 & 200.506 & 413.760 & 313.216 & 311,5 & & & \\
\hline
\end{tabular}

Fuente: INE: Padrón continuo, www.ine.es; para 2001, IVE: explotación especial de la rectificación padronal. Elaboración propia. 
desequilibrio entre la oferta y la demanda de empleo que ya se observa en algunas ciudades del litoral (Viruela, 2002). Sin embargo, los inmigrantes consideran que la residencia en pueblos del interior es sólo temporal (Esparcia, 2002), una etapa más de un proyecto que les llevará a municipios en los que esperan encontrar una oferta de trabajo más amplia y variada.

La distribución espacial muestra interesantes diferencias a escala provincial, comarcal y municipal, según el origen de los inmigrantes. Así, mientras en la provincia de Alacant son más numerosos los extranjeros procedentes del Reino Unido y Alemania, Ecuador y Colombia son los países con más efectivos en la de València, y en la provincia de Castelló el grupo más importante es el de los rumanos. Hay colectivos que tienden a concentrarse en determinadas áreas. Es conocido el caso de los ciudadanos de la Unión Europea que residen en las comarcas del litoral meridional, por ejemplo, el 72\% de los británicos reside en la Marina Alta y el Baix Segura. Otro tanto ocurre con los rumanos, la mitad de ellos con residencia en la Plana. En cambio, los marroquíes están un poco más dispersos, con colonias más importantes en las comarcas citrícolas y de agricultura intensiva del norte y, sobre todo, del sur del país. Por su parte, los ecuatorianos se encuentran en una situación intermedia ya que buena parte de ellos reside en varias comarcas del sur, aunque València es con diferencia el principal centro de atracción (el 35\% del total).

En algunas comarcas y municipios, el paisaje migratorio es muy variado, como ocurre por ejemplo en Requena-Utiel, con ecuatorianos, colombianos, rumanos y argelinos, como colectivos con mayor número de personas en 2001 (IVE), en la Vall d'Albaida, con marroquíes, ecuatorianos, colombianos, rumanos y búlgaros o en l'Alacantí, con franceses, ingleses, marroquíes, argentinos y colombianos. La mayor diversidad se vive en València, donde a los ciudadanos comunitarios, mayoritarios en la década de 1980 se han ido añadiendo otros colectivos, destacando el de los magrebíes en la década de 1990 y, en fecha muy reciente, los de colombianos y ecuatorianos que son los que cuentan con más efectivos en el momento actual (Torres, 2002). Por otra parte, hay municipios y comarcas donde predominan una o dos nacionalidades. Ingleses y alemanes son mayoría en varias comarcas del sur. En la localidad de Llíber más de la mitad de los extranjeros son ingleses, y más de la mitad de los que residen en la ciudad de Castelló tienen nacionalidad rumana, proporción que se eleva casi al 90\% en Morella, en la comarca dels Ports. Los búlgaros son mayoría en la 
Canal de Navarrés, la Safor y la Costera, y en el municipio de Enguera suponen el 80\% de los extranjeros empadronados. En el valle del Vinalopó hay una elevada representación de colombianos (en Elda-Petrer) y ecuatorianos (en Villena). Más de la mitad de los extranjeros con residencia en Sant Mateu y Dolores, en l'Alt Maestrat y el Baix Segura, respectivamente, son de nacionalidad marroquí.

En muchos casos, los inmigrantes proceden de la misma ciudad o región. Sendas encuestas a marroquíes y senegaleses realizadas a principios de la década de 1990 (Gozálvez, 1993) revelaron que entre los norteafricanos residentes en las provincias de Castelló y Alacant predominaban los oriundos de departamentos y ciudades del litoral norte (Nador, Oujda, etc.), y Dakar era la localidad con más representantes senegaleses. Entre los rumanos de Castelló hay una destacada representación de Targoviste y la mayoría de los búlgaros que residen en Enguera proceden de Dimitrovgrad y Haskovo (Viruela, 2002). La mayor parte de los chinos son naturales del distrito de Quingtian en la provincia sureña de Zhejiang (Petit, 2002).

Estas y otras localizaciones revelan la importancia de las cadenas migratorias en la composición y canalización de los flujos, en la elección de los lugares de origen y de destino de los migrantes. Se trata del «efecto llamada»: los que deciden emigrar se dirigen allí donde se han asentado otros compatriotas, sobre todo familiares y amigos que proporcionan soporte material y logístico al recién llegado. Entre las funciones que la literatura sobre migraciones reconoce a las redes sociales, destaca la de minimizar los costes humanos del desplazamiento: acogida, alojamiento, relaciones para encontrar un empleo, etc. (Gurak y Caces, 1998; Malgesini, 1998; Baganha y Reyneri, 2001, etc.).

\section{LOS TRABAJADORES EXTRANJEROS EN EL MERCADO DE TRABAJO}

Las estadísticas de trabajadores afiliados a la Seguridad Social en alta laboral permiten estudiar la participación de la mano de obra extranjera en el mercado de trabajo. Son datos bastante fiables (Carvajal, 2003), aunque tienen un alto grado de coyunturalidad (Cachón, 2003) y pueden darse casos de pluriactividad (Cinca y Allona, 2002) ya que una misma persona puede estar de alta al mismo tiempo en más de un régimen, esto es, el número de trabajadores puede ser menor que el de afiliados (Barrada, 2003). 
Cuadro 7.3. Trabajadores extranjeros de alta en la Seguridad Social por regiones de procedencia

\begin{tabular}{|c|c|c|c|c|c|c|}
\hline \multirow[b]{2}{*}{ REGIONES } & \multicolumn{2}{|c|}{30 septiembre 1999} & \multicolumn{2}{|c|}{14 enero 2003} & \multicolumn{2}{|c|}{ VARIACIÓN } \\
\hline & EFECTIVOS & $\%$ & EFECTIVOS & $\%$ & EFECTIVOS & $\%$ \\
\hline Iberoamérica & 2.655 & 9,4 & 27.608 & 28,0 & 24.953 & 939,8 \\
\hline África & 7.258 & 25,8 & 21514 & 21,8 & 14.256 & 196,4 \\
\hline Asia & 2.139 & 7,6 & 6.165 & 6,2 & 4.026 & 188,2 \\
\hline Unión Europea & 14.117 & 50,1 & 24.392 & 24,7 & 10.275 & 72,8 \\
\hline Resto de Europa & 1.749 & 6,2 & 18.723 & 18,9 & 16.974 & 970,5 \\
\hline Otras & 253 & 0,9 & 376 & 0,4 & 123 & 48,6 \\
\hline Total & 28.171 & 100,0 & 98.778 & 100,0 & 70.607 & 250,6 \\
\hline
\end{tabular}

Fuente: Ministerio del Interior: Anuario Estadístico de Extranjería 2002. Elaboración propia.

Los resultados recogidos en el cuadro 7.3 dan cuenta de los importantes cambios cuantitativos y cualitativos en la composición de la mano de obra extranjera. En septiembre de 1999, más de la mitad de los 28.000 trabajadores extranjeros eran ciudadanos de la Unión Europea y en enero de 2003 apenas representaban el 25\% de los cerca de 100.000 que participaban en el mercado de trabajo formal. Latinoamericanos y africanos han tenido un mayor incremento numérico, pero el mayor crecimiento en términos relativos corresponde a los nacionales del resto de Europa, casi todos ciudadanos de países poscomunistas. Estos resultados ponen de relieve que, como en otras regiones españolas, en el País Valencià se ha producido una demanda repentina y fuerte de trabajadores extranjeros y que la mayoría procede de países con niveles de renta inferiores a los de España. No obstante, también se han incorporado inmigrantes de países ricos, en especial de la Unión Europea. En la actualidad (cuadro 7.4), Marruecos y Ecuador aportan más efectivos, con 14.000 afiliados cada uno, y entre los dos superan a los trabajadores de la UE. Les siguen, a cierta distancia, Rumania, con unos 8.000 afiliados y Colombia, con más de 7.000. En conjunto, estos cuatro países proporcionan el $44 \%$ de los trabajadores inmigrantes. Pero, la situación es distinta en cada provincia. Así, los rumanos son el principal componente de la mano de obra extranjera en Castelló, los ecuatorianos en València, mientras que en Alacant los marroquíes comparten protagonismo con británicos y ecuatorianos.

Uno de cada cuatro extranjeros cotiza a la Seguridad Social (cuadro 4, columna de la derecha). Pero la relación entre los afiliados a la ss y el total de residentes muestra diferencias notables según el país de procedencia que pueden estar relacionadas con la composición por sexo y edad, con la 
Cuadro 7.4. Trabajadores extranjeros por provincia y regímenes de cotización en enero de 2003

\begin{tabular}{|c|c|c|c|c|c|c|c|c|}
\hline \multirow[b]{2}{*}{ Procedencia* } & \multicolumn{2}{|c|}{ ALACANT } & \multicolumn{2}{|c|}{ CASTELLÓ } & \multicolumn{2}{|c|}{ VALÈNCIA } & \multicolumn{2}{|c|}{ PAÍS VALENCIÀ } \\
\hline & TOTAL & $\%$ & TOTAL & $\%$ & TOTAL & $\%$ & TOTAL & $\% * *$ \\
\hline Marruecos & 6.078 & 14,0 & 3.692 & 23,2 & 4.319 & 11,0 & 14.089 & 46,8 \\
\hline Ecuador & 5.391 & 12,4 & 729 & 4,6 & 7.554 & 19,2 & 13.674 & 31,7 \\
\hline Rumania & 907 & 2,1 & 5.002 & 31,4 & 2.150 & 5,5 & 8.059 & 28,8 \\
\hline Colombia & 3.202 & 7,4 & 909 & 5,7 & 3.240 & 8,2 & 7.351 & 20,9 \\
\hline R. Unido & 5.404 & 12,4 & 178 & 1,1 & 955 & 2,4 & 6.537 & 11,3 \\
\hline Alemania & 3.321 & 7,6 & 301 & 1,9 & 800 & 2,0 & 4.422 & 12,9 \\
\hline Argelia & 1.293 & 3,0 & 653 & 4,1 & 1.895 & 4,8 & 3.841 & 34,2 \\
\hline Francia & 1.703 & 3,9 & 457 & 2,9 & 1.644 & 4,2 & 3.804 & 26,9 \\
\hline Italia & 1.674 & 3,8 & 457 & 2,9 & 1.627 & 4,1 & 3.758 & 44,6 \\
\hline China & 1.330 & 3,1 & 283 & 1,8 & 1.537 & 3,9 & 3.150 & 44,1 \\
\hline Ucrania & 1.277 & 2,9 & 293 & 1,8 & 1.429 & 3,6 & 2.999 & 31,8 \\
\hline Bulgaria & 666 & 1,5 & 139 & 0,9 & 2.015 & 5,1 & 2.820 & 24,2 \\
\hline
\end{tabular}

Regímenes de cotización a la Seguridad Social

\begin{tabular}{lrrrrrrrr}
\hline General & 27.786 & 63,9 & 11.415 & 71,7 & 24.913 & 63,2 & 64.114 & 64,9 \\
Autónomos & 9.027 & 20,8 & 939 & 5,9 & 3.056 & 7,8 & 13.022 & 13,2 \\
Agrario & 5.189 & 11,9 & 2.550 & 16,0 & 8.758 & 22,2 & 16.497 & 16,7 \\
Hogar & 1.373 & 3,2 & 971 & 6,1 & 2.662 & 6,8 & 5.006 & 5,1 \\
Otros & 83 & 0,2 & 41 & 0,3 & 15 & - & 139 & 0,1 \\
\hline Total & 43.458 & 100,0 & 15.916 & 100,0 & 39.404 & 100,0 & $\mathbf{9 8 . 7 7 8}$ & 23,8 \\
\hline
\end{tabular}

*Países que aportan más de 2.000 trabajadores.

** Porcentaje de afiliados a la Seguridad Social sobre el total de personas empadronadas de la misma nacionalidad. Fuente: Ministerio del Interior: Anuario Estadístico de Extranjería 2002. Elaboración propia.

antigüedad de la inmigración o con los motivos (laborales o no) del desplazamiento. Así, por ejemplo, la proporción de colombianos y ecuatorianos que cotizan es relativamente escasa (alrededor del 30\%) en comparación con los marroquíes y los chinos (entre el 44 y el 47\%), pero es superior a la de británicos y alemanes (poco más del 10\%). En cambio, el porcentaje de italianos que cotizan es similar al de los chinos.

Una cuestión de gran interés es la que se refiere al régimen de cotización, que guarda relación con la actividad económica de los trabajadores. Como se indica en el cuadro 7.4, la mayor parte de los extranjeros, al igual que los españoles, están incluidos en el régimen general, es decir son trabajadores por cuenta ajena en la industria o los servicios, siendo en otros regímenes donde se aprecian importantes diferencias provinciales en relación con el predominio de uno u otro colectivo. En Alacant destaca el grupo de trabajadores autónomos, mientras que en Castelló y València predominan los que cotizan en el régimen agrario. 
Figura 7.6. Trabajadores extranjeros afiliados en los regímenes especiales de la Seguridad Social (en abril de 2003). Provincias de Castelló y València
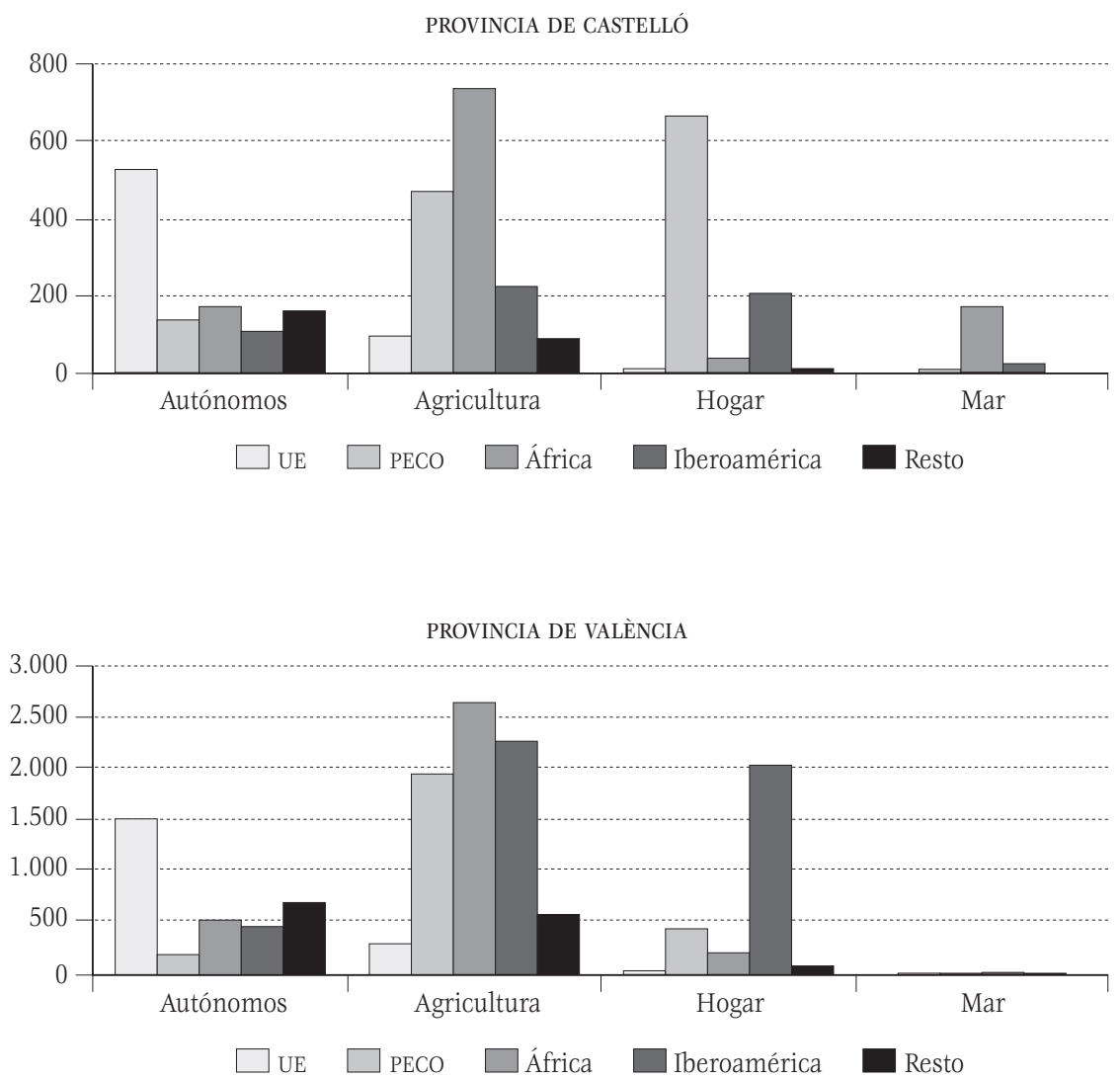

A escala regional y provincial, las estadísticas publicadas no relacionan la nacionalidad con el régimen de cotización. No obstante, la información se puede obtener en las direcciones provinciales de la Tesorería de la Seguridad Social. Los datos de València y Castelló permiten detectar diferencias interesantes según los países o regiones de procedencia de los trabajadores.

En las dos provincias (figura 7.6) la mayor parte de los trabajadores autónomos son ciudadanos de la Unión Europea, pero entre los que se establecen por su cuenta también destacan los chinos y marroquíes, además de los senegaleses, en València, y de los rumanos, en Castelló. 
Hay pocos ciudadanos comunitarios cotizando en el régimen agrario y en el de los empleados de hogar, ya que los empleos a ellos vinculados están ocupados por trabajadores de terceros países. La mayor parte de los agricultores extranjeros son africanos, con predominio de los oriundos de Marruecos en la provincia de Castelló (el 40\%), que en la de València (20\%) se ven superados por los de Ecuador (23\%). En las dos provincias, la agricultura ocupa a un nutrido grupo de europeos del Este, la mayoría rumanos, aunque en la de València el sector agrario también atrae a muchos búlgaros y ucranianos. En cuanto a los empleados de hogar, en Castelló predominan los rumanos (68\%) y en València hay mayor proporción de ecuatorianos (42\%) y colombianos (22\%). El panorama debe ser distinto en la provincia de Alacant. ${ }^{5}$ Allí destaca el gran número de trabajadores autónomos, la mayoría ingleses y alemanes, mientras que el sector agrario es atendido por africanos y latinoamericanos, que también se ocupan en el servicio doméstico y en industrias manufactureras.

Estas diferencias se relacionan con el papel de las redes sociales en la inserción de los trabajadores extranjeros en el mercado de trabajo. En efecto, como han observado Douglas Gurak y Fe Caces (1998), los familiares y compatriotas ya instalados en un sector transmiten información sobre los puestos de trabajo disponibles y de esta forma aumenta la concentración de nuevos inmigrantes en los mismos sectores y ocupaciones y en las mismas comarcas y localidades. Es lo que ocurre, por ejemplo, en las provincias de Castelló y València, donde la mayoría de los extranjeros empleados de hogar son, respectivamente, rumanos y latinoamericanos, o en las comarcas de la Canal de Navarrés y la Costera, donde los búlgaros ocupan buena parte de los empleos agrarios.

Por otra parte, hay que tener en cuenta la gestión que hacen los empresarios de la mano de obra, que aprovechan la abundante disponibilidad de trabajadores extranjeros y la situación irregular de muchos de ellos para flexibilizar el mercado de trabajo. Con el rápido aumento de la corriente inmigratoria y la diversificación de procedencias, el empresario valenciano tiene más donde elegir y, como ocurre en otras regiones (Castaño, 2000; Potot, 2000; Pedreño, 2003; Cachón, 2003), sustituye a unos colectivos por

\footnotetext{
${ }^{5}$ Los responsables de la Tesorería de la Seguridad Social en esta provincia no nos han proporcionado la información pertinente por lo que resulta imposible conocer la distribución de los trabajadores extranjeros en cada régimen de cotización y comparar los resultados con los de Castelló y València.
} 
otros. Sustitución que, con frecuencia, esconde los prejuicios hacia determinados grupos étnicos o la posición de abuso y explotación sobre los recién 1legados (Cachón 2004). En cualquier caso, los procesos de sustitución no son ajenos a las políticas adoptadas en los últimos años que tratan de evitar la excesiva dependencia de un determinado colectivo, como ya se ha comentado. En este sentido, es evidente que la llegada de latinoamericanos y europeos del Este perjudica a los africanos, cuya presencia ya era importante en el sector agrario a principios de la década de 1990 (Viruela, 1993; Gozálvez, 1995) y de características muy diferentes a las de aquellos en cultura, lengua y religión. En el caso de Castelló (Viruela, 2002), la afluencia de inmigrantes de países poscomunistas ha frenado el trasvase sectorial de otros colectivos, en particular de los magrebíes, que quedan relegados a los trabajos más penosos y peor considerados socialmente: agricultura, ganadería, pesca, comercio ambulante, etc. También es frecuente que en una misma empresa o sector de actividad, los trabajadores realicen tareas distintas según la nacionalidad, prefiriéndose a los europeos del Este para los puestos de cierta responsabilidad. En comarcas de agricultura intensiva del litoral meridional, los marroquíes se enfrentan a la dura competencia de los ecuatorianos (Sempere, 2002).

La tasa de actividad de los ciudadanos de la Unión Europea es inferior a la de inmigrantes de terceros países en relación con los motivos del desplazamiento (residencial/laboral) y, entre los ocupados, aquellos destacan por la elevada proporción de empresarios y de trabajadores asalariados fijos. En cambio, en otros colectivos predominan los asalariados con carácter eventual y temporal: más del $60 \%$ de los trabajadores rumanos, ecuatorianos, colombianos o marroquíes, frente al 24\% de los alemanes o el 30\% de los franceses, según los resultados del Censo de 2001 (INE). En general, con ligeras diferencias comarcales y locales, los extranjeros procedentes de países pobres se concentran en unas pocas ramas de actividad: la agricultura, la construcción, el servicio doméstico, la atención a personas mayores, la hostelería, el comercio, etc. Sectores donde las condiciones son peores que la media del mercado laboral y que por ello tienen un bajo nivel de aceptación entre los trabajadores autóctonos, que no están dispuestos a ocupar estos puestos en las condiciones que se les ofrecen y que, gracias a las transformaciones económicas de los últimos años y al aumento general del nivel de bienestar, optan a empleos mejor remunerados en la industria o los servicios. Esto no significa que no haya españoles en aquellas actividades, de hecho son mayoría incluso entre los empleados de hogar, pero la escasez 
de trabajadores podría crear problemas de funcionamiento a no ser por los inmigrantes. Una cuestión que ha sido reiteradamente expresada por las diferentes asociaciones empresariales valencianas. De hecho, sin la mano de obra extranjera no se podría trabajar la tierra en muchos municipios, no se podría afrontar con garantías la campaña citrícola o tener en condiciones muchas granjas avícolas y porcinas, y muchos invernaderos no resultarían rentables; algunas embarcaciones de pesca no podrían hacerse a la mar y el sector de la construcción no dispondría de peones suficientes o especialistas en determinadas tareas, y muchas pequeñas empresas de fabricación de calzado no podrían cumplir sus compromisos. No hay que olvidar, por supuesto, la importancia que han adquirido las trabajadoras extranjeras en tareas domésticas que, en muchas ocasiones, solventan a bajo precio el controvertido problema de la conciliación de la vida familiar y laboral (Mestre, 2002).

Como hemos señalado en trabajos anteriores (Viruela y Domingo, 2001), muchos extranjeros concurren al mercado de trabajo con un nivel de formación y cualificación muy superior al que requiere el puesto de trabajo que ocupan y ello redunda en un menor progreso técnico. Esto es así porque lo que interesa de los extranjeros es el hecho de que se trata de una mano de obra barata, sumisa, obediente y susceptible de ser reemplazada cuando convenga. Obviamente, esta situación no es la más adecuada para la inserción social del inmigrante.

Salvo unos pocos trabajadores contratados en origen, la mayoría de los inmigrantes se incorpora al mercado de trabajo en la etapa irregular. Generalmente los varones lo hacen a través de la agricultura y las mujeres del servicio doméstico, desde donde intentan regularizar su situación. En los primeros momentos los empleos son temporales u ocasionales, alternándose los períodos de actividad con otros de inactividad. Con la regularización, el emigrante trata de abandonar el mercado de trabajo informal y los empleos más precarios. Sin embargo, estos empleos no quedan desatendidos, ya que existe una importante bolsa de inmigrantes «sin papeles» dispuestos a ocuparlos. Unos han llegado recientemente de forma clandestina o como falsos turistas y otros han quedado excluidos de los programas de regularización porque no reúnen los requisitos exigidos.

Al inmigrante le resulta muy difícil mejorar la situación profesional, aunque esté en situación legal y trabaje en el mercado formal. Ante las escasas posibilidades de movilidad vertical, algunos inmigrantes trabajan por cuenta propia. Se trata de trabajadores autónomos y empresarios, sobre 
todo en los sectores de hostelería y comercio, que ocupan mano de obra familiar. También se conocen casos de empresarios en el sector de la construcción con escaso capital y que recurren a la mano de obra barata y sobre todo móvil de sus compatriotas y que trabajan subcontratados por empresas locales que de esta forma tratan de reducir costes. Algunos inmigrantes han organizado grupos que realizan pequeñas obras o «chapuzas» de fontanería, electricidad, albañilería, pintura, etc., y ofrecen sus servicios a precios muy bajos, única posibilidad de competir y hacerse un hueco en el mercado.

\section{A MODO DE CONCLUSIÓN}

La cuantificación del flujo migratorio en España y, en particular, en el País Valencià, ha sido un problema recurrente desde que comienzan a intensificarse las llegadas de extranjeros. Posiblemente, la disparidad de cifras entre los registros oficiales del Ministerio del Interior, las ofrecidas por los Padrones Municipales de Habitantes y la realidad, intuida y constatada en cada nuevo proceso de regularización, ha sido mucho más acusada que en otros países europeos, que también han tenido y tienen una inmigración importante. Aparte de las peculiaridades de la entrada legal e ilegal de inmigrantes en nuestro país, esta permanencia de grandes bolsas de personas en situación de irregularidad inicial o sobrevenida habría que relacionarla con las características del mercado laboral en general y, especialmente, en el País Valencià, donde el trabajo sumergido tiene un arraigo antiguo en diversos sectores económicos a los que, actualmente, se añade el crecimiento de la demanda de servicios en el hogar. En este sentido se entra en un círculo vicioso: por una parte, la seguridad de que es posible trabajar sin necesidad de contrato amplía las expectativas de los inmigrantes y, por otra, la disponibilidad de esta mano de obra barata y «desamparada» legalmente anima la continuidad de la informalidad laboral. En estas circunstancias, a las que se añade la rapidez y el desorden administrativo en que se ha producido la corriente migratoria, es probable que pase mucho tiempo hasta que sea posible contar con unas estadísticas que sean un buen reflejo de la realidad de nuestra inmigración en todos sus aspectos demográficos. Nos preguntamos si las medidas previstas por el gobierno para posibilitar la regularización de inmigrantes con trabajo conseguirán romper esta dinámica. 
A pesar de todo, las cifras disponibles señalan al menos unas tendencias y demuestran que en el País Valencià la población extranjera aumenta y diversifica su composición con gran rapidez. La consecuencia de esta diversidad es que los inmigrantes procedentes de países con niveles de renta inferiores a los de nuestro país ya superan a los de de renta elevada, cosa inimaginable hace apenas una década. No obstante, también las procedencias de ciudadanos de la Unión Europea continúan incrementándose y no hay que perder de vista que la proporción de extranjeros de los países más desarrollados equivale al 40\% del total. Este hecho singulariza al País Valencià con características migratorias propias, frente a los otros grandes centros de recepción, Madrid y Catalunya, donde este porcentaje apenas rebasa el 20 y 12\%, respectivamente (Domingo, 2002). Por tanto, cuando se indican las cifras de foráneos, en nuestro caso conviene distinguir entre los extranjeros residentes, en gran parte no laborales, y la inmigración laboral.

Por todo lo expuesto, la presencia de inmigrantes difiere notablemente de unos municipios a otros y no plantea el mismo problema en todas partes. En principio, la concentración de inmigrados se superpone al modelo territorial valenciano de densa población e intensa actividad económica (agraria, industrial y turística) en la franja litoral donde también se ubican los grandes centros. Pero el incipiente fenómeno de dispersión hacia localidades interiores puede suponer interesantes modificaciones en este ámbito, con una cierta revitalización económica y demográfica, sin descartar también los problemas de relación social que se están produciendo.

En definitiva, para que la sociedad de acogida pueda enfrentarse con éxito a los retos que plantea la inmigración y para la correcta interpretación de este fenómeno necesitamos información estadística fiable y estudios cualitativos. El País Valencià, la tercera región del Estado español en número de inmigrantes, debería contar con un Observatorio Permanente de la Inmigración, donde se centralicen todos los datos y donde se coordine el análisis y la investigación que, cada vez más, requiere de la colaboración de diversas disciplinas académicas. 
8.

\title{
Iguals però menys: \\ la colònia romanesa a Castelló*
}

\author{
Celestí Gimeno i Broch \\ JoAn SERAFÍ BERnat i MarTí
}

* Aquest treball s'ha beneficiat de les ajudes rebudes del projecte UJI P1.IB2003-30. 
El present treball analitza diferents aspectes relatius a la immigració en les terres del nord valencià i dedica una especial atenció a la colònia de romanesos. Aquest collectiu dona a la província la particularitat de ser l'única de tot l'àmbit estatal que té un grup molt elevat de ciutadans de Romania, i que al mateix temps és el més nombrós dintre dels nous ciutadans. ${ }^{1}$ Com es distribueixen pel territori, quina estructura per edats presenten, la proporció d'homes i dones, l'estat civil i el nivell de formació són alguns dels trets que s'estudien. A més a més, en observar l'evolució que presenten algunes d'aquestes variables s'intenta valorar el procés de reagrupació familiar, fase següent que presenta tot moviment migratori després que els "pioners» s'han instal-lat. Altre aspecte que també es tracta és la causa per la qual s'ha produit aquest moviment i perquè Castelló és la quinta província estatal en percentatge d'al-lòctons econòmics (procedents dels països del tercer món i de les economies en transició de l'Europa de l'est). En aquest sentit, després de recordar breument les teories econòmiques sobre els moviments migratoris, es descriuen, per una banda, els factors d'atracció (pull) existents a la província de Castelló, i, per altra, es fa una anàlisi dels factors push (expulsió) que presenta Romania, els quals expliquen la sortida d'aquestos ciutadans del seu país.

Les fonts fonamentals emprades han estat el Cens de població de l'any 2001, els Padrons d'habitants i les seves posteriors rectificacions dels

${ }^{1}$ La denominació del que és una persona que canvia d'estat nacional per buscar treball, divergeix segons els països i els contextos: "minoria ètnica», "treballadors invitats", «auslanders» (originaris de les zones de cultura alemanya de l'Est de Europa), «allochtonen», «immigrants», «estrangers». Nosaltres utilitzarem els conceptes de «nous ciutadans», «al·lòctons», «nouvinguts», «recent arribats», «nouveïns» 0 «nous castellonencs» fent referència al conjunt de persones que formen part dels fluxos migratoris, les quals s'han assentat, viuen i treballen entre nosaltres, i encara no tenen l'estatut de ciutadania a l'Estat espanyol. Estalviarem, per tant, els termes «estrangers» $i$ «immigrants» per tal d'evitar al màxim qualsevol tret excloent, derivat de les seves accepcions negatives. 
darrers anys i part dels resultats d'una enquesta elaborada per el Departament d'Economia de la Universitat Jaume I de Castelló. ${ }^{2}$ A l'apartat corresponent a l'anàlisi dels factors push de Romania també s'han utilitzat dades de l'Institut d'Estadística (NIS) d'aquell país. ${ }^{3}$

\section{INTRODUCCIÓ}

En l'àmbit de les migracions a Europa s'ha produit i s'està produint un fenomen que, a finals de la dècada dels anys vuitanta, no era previsible: els països del sud d'Europa han passat de ser emissors a receptors de fluxos migratoris. Aquesta nova situació es produeix perquè l'Estat espanyol, Grècia i Itàlia (el cas de Portugal és diferent pel peculiar procés de descolonització dels anys setanta) han canviat el seu posicionament dins del món de les migracions internacionals, deixant d'enviar treballadors a altres països $i$ rebent uns fluxos de considerable magnitud procedents d'àrees del Tercer Món i, en diferents graus i nivells, de nous fluxos intra europeus provinents de les denominades «economies en transició» (antics països del socialisme real). Encara que sobre aquest últim aspecte es fa necessari subratllar que la importància d'aquests collectius a nivell continental és relativa. ${ }^{4}$

Els països mediterranis no són «homogenis» i presenten diferències en diversos aspectes com ara l'origen dels fluxos, les etapes, les lleis d'estrangeria, els processos de regularització, etc. (Mendoza, 2001). Concretament, a l'Estat espanyol han existit tres períodes d'immigració (Muñoz-Pérez, 1989; Gozálvez, 1990, 1992 i 1996; Izquierdo, 1996; Huttoon, 1988; i Colectivo Ioe, 2002): la dècada dels anys seixanta, ${ }^{5}$ més significativa per l'inici

${ }^{2}$ L'enquesta s'ha efectuat entre més de tres-cents ciutadans romanesos i es troba en aquestos moments en fase de tractament definitiu. Alguna d'aquestes informacions han aportat trets complementaris a les conclusions que poden extraure's de les fonts oficials.

${ }_{3}^{3}$ Malgrat que molts estudis han ficat de relleu les greus limitacions que presenten aquestes estadístiques, en no existir-ne altres de millors, són les més emprades per analitzar aquest fenomen. Caldrà, per tant, ser prudents al interpretar les xifres que ofereixen.

${ }^{4}$ Els immigrants de l'Europa de l'Est l'any 1999 tan sols suposaven el 0,2 del total de la població de l'Europa comunitària i la proporció no ha canviat molt des d'aleshores (Martín, 2002).

5 Especialment entre 1962-1967 amb immigració procedent del Marroc i del nord d'Europa amb un creixement anual d'un $12,9 \%$, encara que en xifres absolutes no es van sobrepassar els 150.000. Aquest període coincideix amb una forta emigració d'espanyols a l'estranger. 
de les arribades que per les magnituds assolides; la dels anys vuitanta ${ }^{6}$ període en el qual es parla d'Espanya, per primera vegada, com a país d'immigració; i finalment, la dècada dels noranta. ${ }^{7}$ En aquest últim moment s'han produit de manera inequívoca dues grans novetats: per una banda, el pas de país emissor a receptor en termes absoluts; i per altra, l'arribada de fluxos del Tercer Món ha superat quantitativament els originaris de les nacions riques. ${ }^{8}$

Aquesta migració presenta característiques diferents a la dels anys cinquanta i seixanta, la qual afectà fonamentalment els països del nord i centre d'Europa, per la qual cosa alguns autors la qualifiquen com «nova migració» (Muus, 2000). Efectivament és nova perquè: 1) és recent; 2) als anys 50-60 era majoritàriament intra europea mentre que el nou moviment està globalitzat ja que implica a més de la meitat dels països del món; 3) afecta a nous països europeus, especialment als mediterranis, que no ho havien estat fins ara d'una manera intensa; 4) arriben a zones amb taxes de desocupació (almenys oficials) molt altes (10-12\% d'atur estructural en el cas de l'Estat espanyol) i, com ja s'ha apuntat abans, amb grans percentatges d'economia secundària (20-30\% del PIB depenent de les àrees d'assentament) (Flynn 1998); ${ }^{9}$ 5) els estats de benestar que els acullen són menys protectors que els d'Europa dels anys cinquanta i seixanta, perquè aquest model d'estat benefactor, a causa del dèficit fiscal, la fi de les polítiques expansionistes i la competència internacional accentuada per la mundialització, ha sigut qüestionat en tots els països que en gaudien, i en altres (el cas espanyol) que no l'havien acabat d'estructurar s'han quedat a meitat del camí; 6) és un moviment més feminitzat que els anteriors, ja que cada vegada són més les dones que emigren soles i es converteixen en la

${ }^{6}$ L'Estat espanyol comença a rebre immigrants econòmics en quantitats considerables i es promulga la primera llei d'estrangeria (1985), que sota la pressió de la CEE implantà restriccions a l'entrada de ciutadans no-comunitaris. Aquesta catalogació com a país d'immigració ocultava dues realitats importants: 1) el nombre d'emigrats sobrepassava el d'immigrants i 2) el 72\% dels immigrants en 1985 provenia de països rics (Colectivo IOE 2002).

7 Entre 1996 i 2004.

8 Moment que es pot datar en 1997.

9 Tracta d'avaluar la importància de l'economia secundària, gris, submergida, informal, clandestina o illegal als països desenvolupats. Els mediterranis europeus són els que presenten unes taxes més elevades, si bé per a l'Estat espanyol dóna unes taxes molt amples (10-23\%), lleugerament per damunt de la mitjana europea, però per davall d'Itàlia (20-26\%) i Grècia (29-35). Aquestes dades en el cas espanyol encara no han estat modificades per estudis posteriors. 
base que arrossega els homes, fenomen totalment contrari al que era habitual abans; 7) els collectius en moviment són de molt diverses característiques: mà d'obra barata, estudiants, directius, treballadors altament qualificats, etc., i, 8) els al-lòctons no procedeixen dels sectors més pobres i menys educats de les seves societats d'origen.

Lanàlisi d'aquest fenomen atrau l'atenció d'un cada vegada major nombre d'investigadors i adopta una perspectiva interdisciplinar (economia, sociologia, demografia, psicologia, dret, etc.), fet que no és estrany atesa la transcendència dels seus efectes sobre les nostres societats. Per concretar més, es pot afirmar que el migratori és un dels tres fenòmens que estan produint una forta sacsejada en el mercat de treball de les economies capitalistes avançades, juntament amb l'alentiment del creixement i l'envelliment demogràfic (Sneddon Little i altres, 2002).

A l'àmbit social una de les repercussions de la immigració és la disminució de la taxa de dependència (població menor de 15 anys i més de 65/població en edat de treballar), la tendència a augmentar de la qual és un dels grans problemes de les societats més avançades. ${ }^{10}$ Aquest índex està condicionat per diversos factors, com ara l'evolució de l'estructura per edats de la població i de la taxa d'activitat, i aquesta última està molt influenciada per la participació de la dona en el treball fora de la llar. L'Estat espanyol ha tingut al llarg del segle xx una de les poblacions més joves de la Unió Europea perquè la fecunditat començà a disminuir amb cert retard, però l'índex d'envelliment creix a un ritme molt fort, ja que està augmentant la longevitat al mateix temps que disminueix la natalitat. L'evolució definitiva de la situació dependrà de la marxa que prengue la fecunditat en el proper futur perquè, malgrat que darrerament està augmentant la natalitat, l'increment encara no és ni el suficientment fort ni durador per fer cap previsió. D'altra banda, la taxa de participació femenina està per davall de l'europea i encara que hi ha estudis que apunten a que augmenti fins a nivells a l'entorn del 50\%, per a alguns autors no serà suficient per compensar la tendència creixent de la taxa de dependència. Encara que també és just recordar, per tal d'evitar interpretacions catastrofístes, que les conseqüències d'un possible augment de la dependència no es poden avaluar sense tenir en compte l'evolució futura de la productivitat. També

${ }^{10}$ Per alguns autors la incidència de la immigració damunt la taxa de dependència és tan sols un alleujament temporal que, a llarg termini, s'invertirà quan aquests immigrants comencen a jubilar-se (Hollman, 2000). 
a l'àmbit social han aparegut noves problemàtiques abans inexistents: alarma social en alguns ambients, noves necessitats als centres d'ensenyament on s'escolaritzen els nous alumnes, pisos disseminats per la ciutat on viuen els recent arribats en condicions no sempre desitjables, amb la consegüent queixa dels veïns que no entenen aquesta situació, opinions xenòfobes de tot tipus basades en la inseguretat que provoca tota novetat, i també, por en determinades capes socials, les més baixes, a la competència que aquests nouvinguts suposen, etc.

La immigració té conseqüències econòmiques molt importants en l'àmbit laboral i encara que la integració dels nous treballadors en els mercats no és igual en totes les possibles circumstàncies, atès que existeixen estratègies diferents, en general es pot afirmar que: subministren mà d'obra barata per a tasques poc qualificades, socialment desprestigiades i que suposen molt d'esforç físic; és una força de treball submisa que pot ajudar a contenir les reivindicacions dels treballadors autòctons acceptant contractes inestables amb menors prestacions socials; i té clares complicitats amb l'economia submergida.

Els alllòctons es dediquen majoritàriament a activitats relacionades amb el mercat secundari de treball i les necessitats de la classe mitjana ascendent (cura dels xiquets, vells, servei domèstic...), les quals, abans, o be eren reservades a les classes econòmicament més desfavorides o realitzades a l'interior de la família mitjançant el treball domèstic de la dona. En aquest aspecte, estudis espanyols han quantificat en un $81 \%$ del total de treballadors nascuts en un altre país que han entrat irregularment a Espanya i s'han vist obligats a treballar en l'economia submergida (Colectivo Ioe, 2000). Aquesta idea també és defensada per autors estrangers, que fins i tot han anat més lluny, afirmant que la subsistència d'aquests treballadors no seria possible sense l'existència de l'economia negra, idea, per altra banda, coneguda ja des de fa molt de temps (Mingione, 1985). Altres han assenyalat com a principal «efecte de crida» l'existència de la mateixa economia soterrada, difícilment avaluable. Als països mediterranis l'economia és dual i conviuen sectors d'alta i baixa productivitat, i és en aquest últim on les petites empreses familiars, amb baixos nivells tecnològics i productius, «necessiten» aquests treballadors per poder competir. Per tant, no sols es pot afirmar que vénen sinó que indirectament els hem cridat perquè els necessitem. La relació entre economia soterrada i immigració, encara que acceptada per la majoria d'autors, no és fàcil de mesurar perquè es tracta de dues realitats amb distint grau d'il·legalitat: total en el primer cas i en 
gran mesura en el segon. Aquestes característiques impossibiliten la quantificació de dita correlació.

L'antiga migració responia a una rigidesa del mercat de treball: 1'oferta no cobria la demanda; però els fluxos actuals coexisteixen amb taxes d'atur elevades. La resposta a aquesta aparent contradicció l'han buscada molts autors, però les interpretacions més interessants la vinculen a la mundialització i als canvis que ha suposat per al mercat de treball: desregularització, flexibilització i precarietat. Des d'aquesta perspectiva els nous treballadors omplirien aquells segments del mon laboral que els autòctons no volen ocupar en aquestes condicions (Sassen, 1996). Així doncs, primerament es produiria la precarització i la flexibilització i després el fenomen migratori. ${ }^{11}$ En aquest sentit, a l'Estat espanyol hi ha estudis que assenyalen que la immigració i la crisi de l'Estat de Benestar són coetanis (Clavijo, 2002), mentre que altres afirmen que en el moment de l'arribada d'aquests fluxos el model de redistribució ja estava en crisi. Siga com siga, és clar que això implica menys polítiques de discriminació positiva afavoridores de la integració dels nous ciutadans i reaccions xenòfobes, de les capes autòctones més necessitades d'ajuda social, per la competència que l'atenció als al·lòctons, ja de per si escassa, pugi ocasionar. Açò s'està produint, malgrat que els nous treballadors han fet una enorme aportació al gris Estat de Benestar espanyol, la consolidació dels comptes de la Seguretat Social. Aquesta té superàvit des de 1999 a causa de l'augment de cotitzants, fenomen en gran mesura possibilitat pels nouvinguts (u de cada quatre nous cotitzants l'any 2000 era al·lòcton). També és pot afirmar que, al moment de l'arribada dels primers fluxos, a l'Estat espanyol s'estava configurant un «nou model social» caracteritzat per la precarització, la desindustrialització i la polarització social, en augmentar les desigualtats en el repartiment de la renta (Aja, 2000).

Aquest nou marc de les societats d'acollida comporta que la integració, en termes generals, s'està realitzant de manera diferent a com es va produir fa cinquanta anys, la que podríem anomenar primera onada migratòria. Pugliese (1995) i altres autors (Bolzman, 1999; Muus, 2000) han ressaltat aquesta idea. No s'integren en el sector industrial ${ }^{12}$ sinó en altres

${ }^{11}$ La prova d'açò és que a la Unió Europea, ja després d'haver-se posat en marxa les polítiques migratòries restrictives, es fan excepcions per als treballadors estacionals estrangers, per als altament qualificats (brain drain), o per als demandants d'asil, etc.

12 Encara que a la província de Castelló, especialment els nous ciutadans d'origen romanès, ho han fet en major proporció degut a l'enorme impuls industrial. 
sectors econòmics (construcció, comerç, serveis), entre altres raons perquè l'ocupació industrial ha deixat de créixer. ${ }^{13}$ Les condicions de treball són més inestables i els contractes més temporals, la qual cosa és atribuïda per Pugliesse a la decadència del model fordista-taylorista. Hi ha major taxa de desocupació, cosa que fa que, encara que els autòctons no desitgen els llocs de treball ocupats per aquests nous ciutadans, en conjuntures personals d'atur no els descarten absolutament, i per tant, explica que, per a determinats nivells de qualificació dels autòctons, hi haja por a la competència d'aquesta mà d'obra barata i desprotegida jurídicament. El fet que els països d'arribada presenten les taxes d'economia submergida més grans d'Europa influeix perquè «ajuda» a la «integració» d'aquesta nova ma d'obra dins del mercat secundari. Finalment, la integració també depèn del nivell i del tipus d'Estat de Benestar, del grau de regulació dels mercats de treball i de la manera com s'inclouen o s'exclouen els nous ciutadans dels drets socials i polítics.

És en aquest context en que tant l'Estat espanyol com la província de Castelló en particular, han sigut receptors d'una considerable quantitat d'al·lòctons en un breu període de temps. I encara que 1'Estat espanyol presenta menors percentatges de població i d'estoc de força de treball al·lòctones, que els nostres socis europeus més desenvolupats (Sopemi, 2002), no per això el fenomen migratori deixa de tenir grans repercussions a la nostra societat.

\section{TEORIES ECONÒMIQUES SOBRE ELS MOVIMENTS MIGRATORIS}

A data d'avui es pot sostenir que no existeix una teoria integrada sobre el fet migratori, sinó més prompte una sèrie d'aproximacions parcials que s'han desenvolupat des de diferents disciplines. Una de les escoles més tradicional és aquella que intenta explicar els processos migratoris utilitzant un esquema de factors d'atracció-repulsió (pull-push en terminologia anglosaxona). Des d'aquesta posició, els moviments migratoris estarien provocats i explicats per un conjunt de causes que actuarien a l'emissor i impulsarien una determinada part de la seva població a prendre la decisió d'abandonar-lo per dirigir-se a un altre estat receptor. Al mateix temps, en

${ }^{13}$ En general, es pot afirmar que s'introdueixen en els sectors econòmics no susceptibles de deslocalització competitiva. 
aquest darrer país una sèrie de factors actuarien com efectes de crida i provocarien la direcció dels fluxos migratoris cap al seu territori. La intensitat dels fluxos estaria determinada per la força d'uns i altres factors i el balanç final de la interrelació de les dues forces (Portes i Börözc, 1989).

Utilitzant el mercat de treball com element explicatiu primordial de les migracions hi ha dos grups de teories neoclàssiques: la microeconòmica i la macroeconòmica. La primera defensa com a motor fonamental del moviment migratori la diferència de nivells salarials entre els 1locs emissors i els receptors: el flux es dirigiria des del lloc amb menys nivell salarial cap al de major nivell. Al final del procés l'equilibri salarial es restabliria i cessaria el moviment de població (Ranis i Fei, 1961; Massey, 1993). Al seu torn, les teories microeconòmiques defensen que la migració és un fenomen individual i que són les persones les que prenen la decisió després de fer una anàlisi cost-benefici. Des d'aquest punt de vista, la migració seria una forma d'inversió en capital humà. Els costos inclourien no sols les despeses de viatge, sinó també l'absència de salari mentre es cerca treball, els esforços d'adaptació a un altre país i la pressió psicològica. Aquests peatges no serien uniformes i dependrien de la constitució i de les circumstàncies individuals (Todaro, 1976; Sjaastad, 1962). Altres aportacions consideren que la decisió de migrar no és presa per un actor ailllat sinó per famílies o llars atenent la maximització dels ingressos i la minimització dels riscos. L'objectiu seria la diversificació dels recursos familiars, protegint d'aquesta manera al grup de les disfuncions dels mercats domèstics. S'exportarien individus per acumular capital que servivien de motor de creixement econòmic del país emissor (Stark, 1984; Ghatak i Levine, 1993).

També s'ha de recordar l'existència de treballs i autors que donen una importància determinant a les característiques del mercat de treball dels països d'acollida: la constant demanda de mà d'obra de les societats industrials avançades en els segments de menor qualificació i retribució seria el motor fonamental (Piore, 1979). Els immigrants acceptarien aquestes condicions per la voluntat d'ascendir socialment en les seves societats originàries. Tot aquest procés estaria aprofundit en aquests moments pel fet que les societats avançades han entrat en una fase d'envelliment accelerat, la qual cosa augmentaria la demanda de mà d'obra al-lòctona.

Per finalitzar aquesta aproximació a les diverses teories cal dir que en els darrers anys s'han desenvolupat tota una sèrie d'estudis que posen l'èmfasi en el paper que les xarxes i el seu funcionament juguen en les 
migracions internacionals (Massey i altres, 1987; Kritz i altres, 1992). La xarxa es defineix com una mena de relacions familiars, d'amistat o pertinença a una mateixa comunitat entre emigrants, antics emigrants i la població que es queda al país d'origen, que produirien informació sobre on emigrar, com fer-ho, la possibilitat de trobar un 1loc de treball, habitatge i sobretot podrien ajudar a eludir les restriccions d'entrada. La decisió de migrar o l'elecció del país on es poden dirigir dependria en gran mesura de les informacions que es tingueren a l'abast abans d'emigrar: existència d'afinitats lingüístiques, notícies passades de boca en boca sobre la conjuntura econòmica, la situació del mercat de treball, etc. serien factors que es poden conèixer prèviament. Des d'aquest punt de vista, les regularitzacions o/i les polítiques d'integració dels immigrants de llarga duració podrien servir per atraure més immigrants i el flux migratori es convertiria en un procés de difusió continu, autosostingut i retroalimentat (Massey, 1993).

Aquestes aproximacions no s'exclouen entre si en tots els seus aspectes, i els estudis més recents tendeixen a tenir en compte una pluralitat d'elements, difícilment catalogables en un únic punt de vista dels abans esmentats. Així i tot, els motius pels quals un individu pren la decisió d'anar-se'n de casa per intentar refer la seva vida en un altre indret són molt variats i de vegades buscar el benestar és sols u dels motius de la partida, tal i com explica Enric Valor el pensament del masover de la Tilllera, a les rodalies d'Aitana, de principis del segle xx:

Si, Eldorado, la terra de promissió. Bernat té un pensament agosarat i fix; allà a Amèrica és on ell pot fonamentar la bona sort del seu Angelet. D'allà estant, ell procurarà que no li falte res: vestirà bé, menjà bé, estudiarà tot allò que ell no ha pogut estudiar, tot allò que donarà la intel-ligència del xiconet, que ell bé troba que deu ser molta [...] Bé està allò de l'Amèrica pel seu fill. Hi ha més, però. Ell no s'ho vol dir mai. Bernat ha fet la guerra i això no pot girar-se ja mai del revés: passar el mar, viure en terres noves, immenses, en un món grandiós i desconegut, són coses que l'atrauen. Bernat és ja això: un esperit aventurer que, en aquella pau tirant a idíllica, però malmesa per les penes, de la Tilllera, veu, sent, sap, que se li rovella i esmorteeix la part més brava i noble del seu esperit. I tampoc no es confessa que té por - per més fort que es senta- d'ell i de Basília. Per res del món no trairia una altra vegada el seu germà, que tants anys li féu de pare. I si es quedàs a la Tilllera, és segur que sucumbiria. (Valor, 1987) 


\section{El MODEL MigRATORI DE CASTELló DinS DEL CONTEXT ESTATAL}

A l'Estat espanyol hi havia a data 1 de gener de 2003 un total de 2.664.168 al.lòctons dels quals 1.414 .750 eren homes i 1.249 .418 dones. ${ }^{14}$ Aquestes xifres representaven el 6,24\% de la població total del país (42.717.064 habitants), per ser més exactes el 6,73\% del total d'homes i un $5,76 \%$ del total de dones. Com s'ha dit abans, aquestes xifres, comparades amb les dels nostres veïns i socis europeus amb molta més tradició immigratòria, eren relativament modestes, encara que la taxa de creixement, parcialment per raons estadístiques, ${ }^{15}$ fora de les més fortes de la UE. ${ }^{16}$

La distribució geogràfica era i és molt desigual, i es pot afirmar que la major part estan concentrats a la façana mediterrània (incloses les Illes Balears), Canàries i Madrid, ja que el 70\% viuen a Madrid, Catalunya, País Valencià i Andalusia. Aquesta concentració obliga a fer una primera crida d'atenció: no es pot parlar de la totalitat de l'Estat com a zona d'immigració, és més adequat establir l'existència d'una dicotomia, que fa que les problemàtiques derivades de la gestió dels fluxos migratoris es visquen amb una intensitat diferent. ${ }^{17}$ Aquest darrer aspecte explicaria el fet que per a algunes nacionalitats i comunitats autònomes siga més prioritària l'assumpció de competències sobre la política migratòria (en aquests moments exclusiva del govern central) que per a altres.

També l'increment entre el Cens d'1 de novembre de 2001 i el Padró d'1 de gener de 2003, que en ser general per tots els àmbits geogràfics, va tindre una intensitat desigual. La mitjana estatal va ser de 63\%, per damunt d'aquesta xifra es trobaven el País Valencià (màxim augment, amb el $77,5 \%)$, Catalunya $(66,1 \%)$, Canàries $(64,1 \%)$ i Balears $(63,5 \%)$, mentre que la resta de les comunitats presentaven percentatges inferiors.

14 Padró municipal d'1 de gener de 2003.

15 És molt important recalcar que aquest increment conté, en part, un mirall estadístic, en el sentit que no és que hagin vingut en aquest curt interval de temps sinó més prompte que estaven vivint entre nosaltres i sols s'han inscrit en el Padró municipal amb posterioritat al moment de la seva arribada. Al respecte es pot veure el treball d'Andreu Domingo a aquest mateix volum.

${ }^{16}$ L'any 2002 Espanya va ser, després d'Itàlia, el país que en termes absoluts on més immigrants es van inscriure de tota la UE.

17 El concepte "problemàtica» està utilitzat aquí en llur accepció de conjunt de qüestions i aspectes que cal resoldre per tal de garantir una inclusió que garanteixi als nous ciutadans l'equiparació real en els drets i deures de ciutadania. 
Quadre 8.1. La distribució percentual dels al·lòctons respecte a la població total provincial, 2003

\begin{tabular}{lrllll}
\hline Alacant & 15,06 & València & 5,73 & Lleó & 2,31 \\
Balears (Illes) & 13,35 & Saragossa & 5,35 & Valladolid & 2,24 \\
Girona & 11,22 & Segòvia & 5,25 & Pontevedra & 2,19 \\
Madrid & 10,30 & Toledo & 4,96 & Guipúscoa & 2,17 \\
Almeria & 9,95 & Osca & 4,64 & Àvila & 2,12 \\
S. C. Tenerife & 9,85 & Terol & 4,58 & Biscaia & 2,11 \\
Màlaga & 9,47 & Conca & 4,34 & Salamanca & 2,02 \\
Palmes (Les) & 9,12 & Sòria & 3,99 & Cadis & 1,72 \\
Múrcia & 8,97 & Àlaba & 3,71 & Corunya (La) & 1,62 \\
Castelló & 8,45 & Albacete & 3,55 & Lugo & 1,45 \\
Barcelona & 7,89 & Burgos & 3,54 & Sevilla & 1,44 \\
Tarragona & 7,78 & Orense & 3,07 & Palència & 1,28 \\
Rioja (La) & 7,16 & Granada & 2,94 & Jaén & 1,10 \\
Navarra & 6,70 & Ciudad Real & 2,79 & Còrdova & 1,09 \\
Lleida & 6,38 & Càceres & 2,61 & Badajoz & 1,08 \\
Mitjana estatal & 6,24 & Huelva & 2,61 & Zamora & 1,05 \\
Guadalajara & 5,73 & Cantàbria & 2,49 & & \\
\hline
\end{tabular}

Font: Elaboració pròpia a partir de les dades del Padró de 2003. Instituto Nacional de Estadística.

La distribució provincial del creixement remarca encara més la dicotomia costa-interior, perquè al conjunt de les províncies costaneres de la Mediterrània i Canàries s'establien el 59,5\% del total dels nous veïns originaris d'altres països, al temps que Madrid representava el 22,1\% del total. La resta de l'Estat aglutinava a altra quarta part. La concentració dels fluxos s'accentuava si afegim al primer grup l'eix de l'Ebre (Navarra, Saragossa i la Rioja), aleshores el percentatge pujava al 87\% del total. Castelló ocupava el lloc catorzè amb un total de 43.789 nous ciutadans aveïnats, quantitat que representava un 1,65\% del total estatal d'empadronaments d'alliòctons,$^{18}$ però en termes relatius a la població provincial era la desena amb més nouvinguts (8,45\%), per davant fins i tot de Barcelona $(7,9 \%)$ i de València $(5,7 \%)$.

Si es relacionen els al-lòctons en edat laboral i la població activa espanyola, els percentatges ofereixen una nova perspectiva i reflecteixen la importància d'aquests fluxos per a l'economia. Castelló, amb un 16,5\%, era la novena província en percentatge d'alllòctons respecte de la població activa, però considerant que Alacant, Balears, Santa Cruz de Tenerife

18 Més endavant es veurà com aquesta quantitat amb relació a la potència demogràfica total de la província és més seriosa del que sembla. 
i Les Palmes són àrees amb predomini d'immigració procedent de països rics, el 1loc real que ocuparia per immigració econòmica és el cinquè, darrere d'Almeria (20,2\%), Madrid (19,4\%), Múrcia (18,4\%) i Girona $(17,4 \%) \cdot{ }^{19}$

Altre aspecte que cal ressaltar és que no tots aquests immigrants tenien papers, ${ }^{20}$ perquè, segons dades de la Direcció General de la Policia a 1'1 de gener de 2003, tan sols 1.647.011 al-lòctons podien ser considerats com residents legals, és a dir, el 62\% del total de ciutadans vinguts d'altres països. L'índex d'irregularitat tampoc era uniforme, doncs no totes les autonomies ni províncies tenien la mateixa disposició administrativa a l'hora de tramitar les sol-licituds de regularització. Així mateix, el percentatge també depenia de l'origen de cada comunitat allòctona. La comunitat dels països europeus orientals (de la qual més del $80 \%$ eren romanesos) a Castelló era la que tenia uns percentatges d'irregularitat més alts de totes les analitzades, fet que hauria de relacionar-se amb que hi havia un flux migratori circular i continu entre Romania i Castelló l'obtenció de papers, doncs, no era tan prioritària i sols es donaven de baixa al Cens del seu país d'origen en cas de trobar treball estable al país d'acollida.

Quadre 8.2. La distribució de la irregularitat segons l'origen. Castelló 2002

\begin{tabular}{lccc}
\hline & TOTAL D'AL'LÒCTONS & AMB PAPERS & \% DE REGULARITAT \\
\hline Països de l'Europa oriental & 10.066 & 2.049 & 20,4 \\
Països àrabs & 6.980 & 5.158 & 73,9 \\
Països sudamericans & 6.273 & 1.728 & 27,5 \\
Països rics & 4.471 & 3.483 & 77,9 \\
Xina & 457 & 347 & 75,9 \\
Subsaharians & 165 & 85 & 51,5 \\
Total & 30.818 & 13.474 & 43,72 \\
\hline
\end{tabular}

Font: Elaboració pròpia a partir de dades del Padró 2002 i de la Direcció General de la Policia a l'1 de gener del mateix any.

La distribució segons l'origen dels collectius dels nous ciutadans està relacionada, d'una banda, amb les ocupacions on s'insereixen, i d'altra, amb les xarxes de crida que funcionen entre ells. Amb les dades del Cens de 2001 a l'Estat espanyol es dibuixaven diversos models segons el predomini d'unes comunitats d'alllòctons o d'altres:21

19 Aquesta última també amb una forta influència turística deguda a la Costa Brava.

${ }^{20}$ Expressió que déu entendres de manera figurada perquè de papers en tenen totes les persones. Altra cosa és que no tinguen els documents que les societats d'acollida exigeixen.

${ }^{21}$ Aquests trets ja existien abans (Aja, 2000: 38-39). 
1. Model amb preponderància d'europeus rics i com a segona comunitat els originaris d'Amèrica del sud i central: les Illes Balears, les Canàries, el País Valencià i Andalusia. El cas d'aquesta darrera autonomia cal matitzar-lo perquè el segon lloc estava ocupat pels originaris dels països àrabs, però amb un percentatge pràcticament igual hi eren els sud-americans, i perquè els portuguesos tenen un pes especial, com es veurà més endavant.

2. Model de predomini dels sud-americans. Dins d'aquest hi havia tres grups: 2.1) Sud-americans i europeus rics: Estat espanyol (mitjana), País Basc, Galícia22 i Castella i Lleó; 2.2) Sud-americans i àrabs: Navarra, Múrcia, la Rioja, Catalunya, Castella-la Manxa i Aragó; 2.3) Sud-americans i europeus de l'est: Madrid.

3. Model de predomini àrab: Extremadura (sobretot a la província de Càceres).

Les xifres del Padró del 2003, encara que no coincideixen completament amb les del Cens anteriors, permeten afirmar que els models definits abans no havien canviat substancialment. L'anàlisi provincial permet les següents matisacions: 1) el predomini dels europeus rics era clar a les Balears i a Canàries, però a les altres dues comunitats (País Valencià i Andalusia) el detall provincial fa entreveure que, en realitat, hi havia models múltiples, ja que, per una banda, eren les províncies de Màlaga, Cadis i Huelva (aquesta última amb predomini de portuguesos) les que donaven el resultant del model a tota Andalusia; pel que fa al País Valencià, era Alacant la que decantava al conjunt vers al predomini europeu ric, per què les altres dues províncies tenien, cadascuna, composicions diferents. Per altra banda, també hi havia predomini d'europeus rics, naturals de Portugal, a la província d'Orense; 2) el que s'ha definit com model extremeny (predomini d'àrabs com a primera colònia) sols es devia a Càceres, atès que era el seu percentatge (66\%) d'àrabs el que canviava la realitat comunitària. A Badajoz els dos grups predominants eren el dels hispans i el dels europeus rics (portuguesos). És a dir, igual que a pràcticament totes les províncies limítrofes amb Portugal, més Astúries, La Corunya i Lugo (excepció feta d'Ourense); 3) sols hi havia sis províncies amb àrabs com a primera colònia: Girona, Lleida, Tarragona, Càceres, Huelva i Almeria.

22 A causa de l'elevat nombre de treballadors portuguesos. Es tracta d'un mirall estadístics, donat que aquesta presència també és migració econòmica. 
Cridaner es el fet de que Barcelona era diferent a la resta de Catalunya i presentava un model semblant al de Navarra, La Rioja, Àlaba, Múrcia, Jaén i Còrdova, la qual cosa també permet parlar de dicotomia a Catalunya; 4) quatre províncies que tenien un model completament diferent als que s'han definit abans, amb predomini del grup provinent de les economies en transició i amb els hispans en segon 1loc. Són Segòvia (amb el 51\%), Castelló (43\%), Conca (38\%) i Terol (35\%). No obstant, una anàlisi més al detall revela que de les quatre, la que tenia xifres de nous ciutadans més significatives era Castelló (43.789) perquè la resta no arribaven als 10.000; que Segòvia tenia un predomini de búlgars (75\%) i, per a finalitzar, que Castelló tenia una majoria aclaparadora de romanesos (83\%) del total d'alllòctons procedents de l'Est europeu; 5) finalment, la resta de les províncies presentaven un predomini d'hispans com a primera colònia i europeus orientals en el segon 1loc (model 2.3).

D'aquest anàlisi provincial convé destacar dues conclusions: 1'heterogeneitat amb la qual es distribueixen espacialment aquests nous vinguts fa que les divisions provincials es constitueisquen en unitats territorial més explicatives del diferents models que s'han desenvolupat a l'Estat espanyol, que no pas les nacionalitats, regions o comunitats autònomes. I que la província de Castelló compta amb una remarcable especificitat dins de l'actual panorama migratori, que es concreta en l'alt percentatge d'immigrants econòmics que acull i en el predomini aclaparador que han assolit els ciutadans de Romania.

\section{TRETS DEMOGRÀFICS DELS IMMIGRANTS A CASTELLÓ}

A aquest apartat s'analitzen les principals característiques poblacionals dels nouvinguts que viuen a Castelló, dedicant una especial atenció a la colònia romanesa i intentant esbrinar les similituds i diferències que aquest collectiu presenta no tan sols front als altres alllòctons de la província, sinó també davant dels nous ciutadans d'altres territoris de l'Estat i, fins i tot, respecte dels castellonencs autòctons. No ens detindrem en la descripció del procés d'inserció al mon laboral, per haver estat tractat en un altre 1loc. ${ }^{23}$

${ }^{23}$ A les III Jornades Valencianes d'Estudis Regionals, celebrades a Alacant en gener de 2005, vam presentar una comunicació titulada «Model migratori i tipologia d'inserció laboral a Castelló", que aviat serà publicada dins les actes d'aquest congrés. 
Gràfic 8.1. Evolució de la població de la província de Castelló, diferenciant entre autòctons i al·lòctons, 1991-2005. Base 100 en 1991

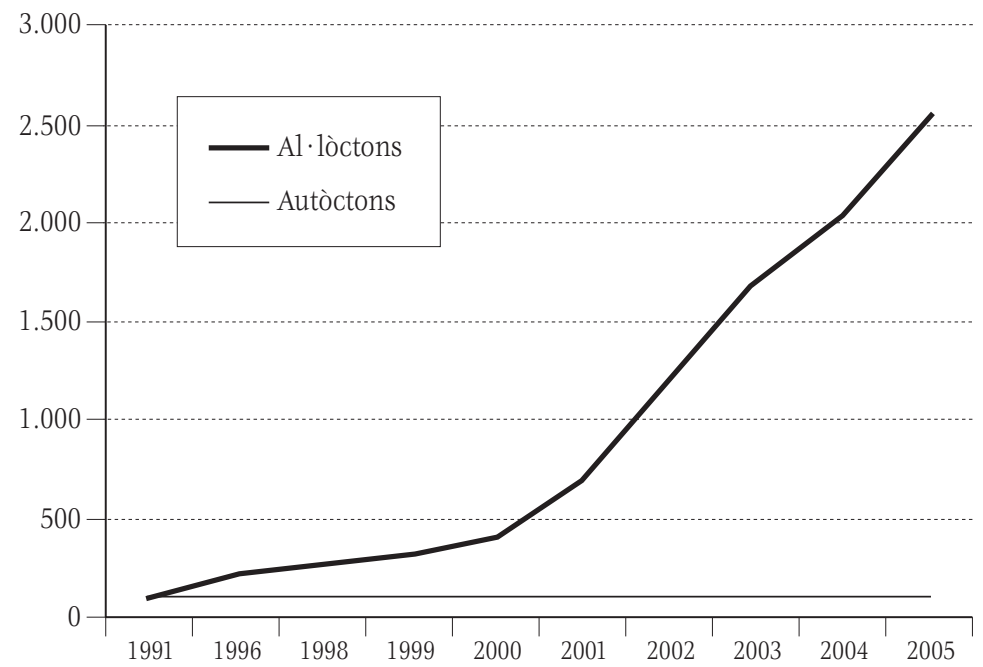

Font: Elaboració pròpia a partir de les dades del Cens de 1991, padrons i rectificacions de 1996, 1998, 1999, 2000, 2001, 2002, 2003, 2004 i xifres provisionals del Padró de 2005. Instituto Nacional de Estadística.

\section{El creixement recent del nombre d'al·lòctons a Castelló}

De la mateixa manera que a l'Estat espanyol i al País Valencià, l'onada immigratòria a Castelló és un fenomen relativament recent que s'ha produit durant el darrer govern del Partit Popular. Segons el Cens d'1 de març de 1991 a la província vivien 446.744 persones, de les quals sols 2.563 (és a dir, el 0,57\%) eren nouvinguts. Al Padró d'1 de maig de 1996 aquest nombre pràcticament s'havia duplicat, però així $\mathrm{i}$ tot, n'eren 5.620 (el 1,23\% de tots els habitants). A la revisió padronal d'1 de gener de 2000 arribaven a 10.326, i l'estadística tornava a reflectir el moderat increment del potencial demogràfic de les comarques septentrionals valencianes, ja que comptabilitzava a 474.385 residents. Per tant, a la dècada dels noranta mentre els ciutadans autòctons van augmentar un 4,5\%, els al·lòctons es van multiplicar per quatre. Però amb el nou segle les arribades s'han disparat, en passar d'un creixement anual acumulatiu a la darrera dècada del segle xx del 1,65\%, al 6,19\% entre 1'1 de gener de 2000 i la mateixa data de l'any 2003. Aquesta evolució va motivar que el primer dia del 2003 hi haguera 43.789 al-lòctons inscrits als municipis castellonencs, front a 474.450 autòctons. En termes 
Quadre 8.3. Variacions del nombre d'al·lòctons residents a la província de Castelló i taxes de creixement anual acumulatiu

\begin{tabular}{lrrrrrrrrr}
\hline & $1991-96$ & $1996-98$ & $1998-99$ & $1999-00$ & $2000-01$ & $2001-02$ & $2002-03$ & $2003-04$ & $2004-05$ \\
\hline Variacions & +3.057 & +1.222 & +1.124 & +2.360 & +7.652 & +12.840 & +12.971 & +8.458 & +12.812 \\
$\begin{array}{l}\text { Creix. anual } \\
\text { acumulatiu }\end{array}$ & 16,41 & 13,26 & 16,43 & 29,63 & 74,10 & 71,42 & 42,09 & 19,32 & 24,52 \\
\hline
\end{tabular}

Font: Elaboració pròpia a partir de les dades del Cens de 1991, padrons i rectificacions de 1996, 1998, 1999, 2000, 2001, 2002, 2003, 2004 i xifres provisionals del Padró de 2005. Instituto Nacional de Estadística.

relatius això suposava que aquells ja arribaven al 8,45\%, quant tres anys abans a penes passaven dels dos punts. Al darrer bienni s'ha mantingut la tendència, i a 1 de gener de 2005, amb dades provisionals del Padró, a la província de Castelló viurien 542.267 persones, de les quals 65.059 eren els nous ciutadans. Com reflecteixen les xifres anteriors, el ritme d'augment de la població autòctona ha estat moderat (de 1991 a 2005 sols s'ha multiplicat per 1,07 ) mentre que la dels al·lòctons ho ha fet de manera molt potent (en les mateixes dates s'ha incrementat en un 2.538\%).

El sistema estadístic actual espanyol no permet fixar amb suficients garanties de fiabilitat els fluxos immigratoris anuals, però les comparacions dels contingents que hi havia en cada moment censal o padronal permeten apropar-se a dits moviments.

Aquestes dades permeten constatar que en termes absoluts els majors guanys s'han produit durant els darrers cinc anys, però els ritmes d'augment s'han moderat significativament durant el 2003 i el 2004, la qual cosa permet encarar els reptes de la integració amb menys dramatisme que abans de conèixer-se aquestes informacions. ${ }^{24}$

\section{L’origen dels nous ciutadans a Castelló}

Els més de 65.000 habitants nouvinguts pertanyen a un ample ventall de països, situats a totes les grans àrees i regions del planeta, però la seva distribució segons aquest distintiu és molt irregular, ben peculiar, com ja

24 De tota manera, aquestos increments extraordinaris posen damunt la taula la radical necessitat d'engegar polítiques urgents d'inclusió, que vaguin més enllà de processos de regularització. Aquestes mesures han d'aconseguir, dintre del principi de discriminació positiva, i en el termini més curt possible, convertir a aquests nouvinguts en ciutadans reals. Tota persona que treballe aquí, pague impostos i quotitze a la seguretat social ha de gaudir de tots els drets, per tal de convertir-se en autèntic valencià. 
Gràfic 8.2. Evolució de la distribució percentual de les colònies més representatives d'alllòctons a la província de Castelló, 1991-2005

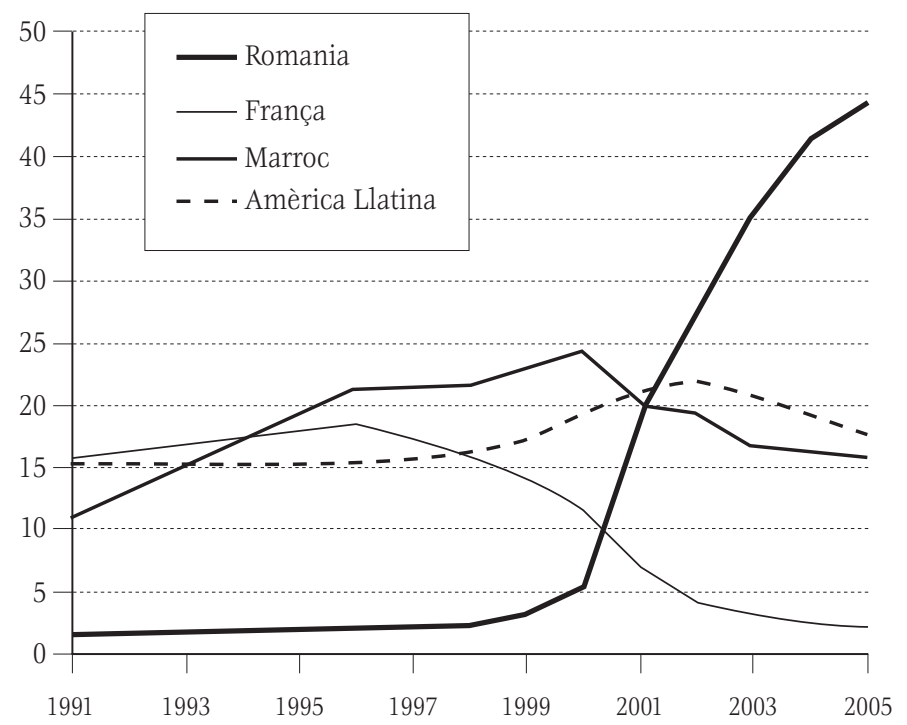

Font: Elaboració pròpia a partir de les dades del Cens de 1991, padrons i rectificacions de 1996, 1998, 1999, 2000, 2001, 2002, 2003, 2004 i xifres provisionals del Padró de 2005. Instituto Nacional de Estadística.

s'ha dit, dins el context estatal i es troba en continuo procés de transformació. La primera diferenciació que, per la seva significació, cal establir ateny al nivell de la renda per càpita del país d'origen. Així, de l'Europa rica, del Nord d'Amèrica, dels antics dominis britànics de poblament blanc i de Japó ni tan sols vivien entre nosaltres l'1 de gener de 2005 poc més de sis mil persones. En canvi, dels països del Tercer Mon i de les economies en transició hi han quasi seixanta mil, es a dir, el 90,1\% dels nous ciutadans de la província provenen de zones econòmicament menys desenvolupades.

Per continents el predomini correspon a Europa, amb un 60,3\%, seguida a distància d'Àfrica (20,3\%) i molt a prop d'aquesta Amèrica (17,4\%), mentre que de la resta del mon la presència es quasi testimonial. Per estats la colònia més nombrosa és la de romanesos, que amb 28.702 ciutadans aporta el 44,1\% del total. Li segueixen, a molta distància, Marroc (10.226), Colòmbia (3.832), Equador (2.173) i Algèria (1.805). A continuació ja es situen dos socis de la Unió, França (1.396) i Alemanya (1.324), i molt a prop Argentina, Itàlia i el Regne Unit, amb poc més d'un miler. 
Quadre 8.4. Taxes de creixement anual acumulatiu de les colònies d'al·lòctons més nombroses a la província de Castelló

\begin{tabular}{lcrrrrrrrr}
\hline & $1991-96$ & $1996-98$ & $1998-99$ & $1999-00$ & $2000-01$ & $2001-02$ & $2002-03$ & $2003-04$ & $2004-05$ \\
\hline Romania & 24,6 & 28,2 & 57,3 & 127,9 & 513,7 & 142,7 & 85,4 & 38,8 & 33,1 \\
Marroc & 32,8 & 14,4 & 24,8 & 35,9 & 44,8 & 64,3 & 22,5 & 15,0 & 22,2 \\
Colòmbia & - & - & - & - & - & 123,5 & 27,0 & 1,0 & 6,5 \\
Equador & - & - & - & - & - & 115,1 & 41,3 & 23,2 & 7,9 \\
Algèria & 24,9 & 22,8 & 17,7 & 55,3 & 51,4 & 70,5 & 27,1 & 6,8 & 13,2 \\
França & 20,1 & 2,7 & 4,6 & 5,7 & 6,4 & 3,6 & 7,8 & $-11,5$ & 10,8 \\
Alemanya & 17,2 & 5,1 & 15,7 & 12,0 & 9,6 & 13,4 & 11,8 & $-16,1$ & 11,7 \\
Argentina & 4,8 & 19,1 & 1,8 & 21,9 & 52,7 & 50,8 & 57,1 & 13,4 & 16,0 \\
Itàlia & 13,2 & 13,3 & 16,8 & 19,1 & 18,8 & 35,8 & 32,5 & 16,6 & 21,5 \\
\hline
\end{tabular}

Font: Elaboració pròpia a partir de les dades del Cens de 1991, padrons i rectificacions de 1996, 1998, 1999, 2000, 2001, 2002, 2003, 2004 i xifres provisionals del Padró de 2005. Instituto Nacional de Estadística.

Però la foto de 1'1 de gener de 2005 sols reflexa una part de la realitat d'eixe moment, ja que l'evolució de la presència dels diferents colllectius als darrers anys ha experimentat canvis substancials, el més espectacular ha estat l'enorme increment de la immigració econòmica. Així, a 1991 el $60 \%$ dels nous ciutadans havien arribat de la zona rica del planeta, i les colònies més significatives n'eren, per ordre decreixent, la francesa, l'alemanya, la marroquí i l'anglesa. A 1996 n'eren uns 3.000, xifra sols lleugerament superior als procedents de la zona en desenvolupament. Però a la primera revisió padronal posterior, la d'1 de gener de 1998, l'avantatge ja era per a les persones arribades del tercer mon i des d'aquest moment fins a l'actualitat la proporció no ha fet més que augmentar: el 55\% en 1999; el 62\% en 2000; el 83\% en 2002; i el 90\% en 2005. Aquesta onada recent d'immigració econòmica ha trastocat el pes de les diferents colònies, ja que si be les dels membres comunitaris han continuat augmentat amb regularitat però amb certa lentitud, la molt forta empenta de les d'alguns països pobres han desbancat la significació d'aquelles. Així, mentre entre 1996 i 2005 els francesos han passat de 1.037 a 1.396, els alemanys ho han fet de 725 a 1.324 i els italians de 239 a 1.226, els romanesos en les mateixes dates s'han multiplicat per 270, en passar de 106 a 28.702. Ha estat tal la força de l'increment dels procedents d'aquest territori la que, fins i tot, ha fet diluir-se la significació dels nord-africans i dels llatinoamericans.

Els diferents ritmes de creixement dels principals grups recullen amb exactitud aquest fenomen. A la primera meitat dels noranta la major potència expansiva la van tenir els marroquins, de manera que en 1996 ja eren els més nombrosos. D'aleshores ençà els qui més s'han multiplicat han 
estat els romanesos, però com que la seva presència abans del 2000 era poc significativa, sols al llarg de l'any 2001 superen en nombre a la resta de nouvinguts. A partir d'aquest moment es convertiran en la colònia dominant, cada vegada amb major diferència.

\section{La distribució espacial dels nous ciutadans a la província de Castelló}

A l'igual que els autòctons, les persones vingudes de fora es distribueixen de manera irregular al llarg de la província, i mostren una forta concentració a les comarques de la Plana i als municipis de la franja costanera del nord, al temps que la seva presència a l'interior muntanyós és escassa. Així, segons el Padró d'1 de gener de 2004, el municipi amb major concentració era Castelló de la Plana (40\% del total), seguit de Vila-real, Borriana i Benicarló (3.136, 3.016 i 3.012, respectivament), després estan Vinaròs i Benicàssim que tenien empadronats més de dos milers, i ja amb quantitats menors, Almassora, Onda, Orpesa del Mar, Peníscola, la Vall d'Uixó i Alcalà de Xivert, tots amb més d'un miler. Entre aquesta quantitat i cinc-cents sols estaven Torreblanca i Nules, per baix i amb més d'un centenar hi havien 23 entitats, amb una xifra inferior a cent estaven 90 municipis i sols en vuit entitats (la més poblada de les quals era Castellfort, amb 218 habitants) no hi havia cap al·lòcton. Per tant, formen part ja de la població de totes les comarques, però tot i que hi ha una correlació positiva entre el nombre d'al-lòctons assentats i el volum de la població d'acollida el coeficient no és significatiu. El gràfic 4 és clar al respecte.

El rànquing de municipis amb major percentatge d'al·lòctons a 1 de gener de 2004 reflecteix que la geografia del poblament autòcton i dels nouvinguts no era plenament coincident. Estava encapçalat per Orpesa de Mar amb un 25,5\% i per Peníscola, amb un 24,5\%, a continuació es situaven Alcalà de Xivert, Torreblanca i Sant Jordi, que en tenien entre un 20,8\% i un 17,4\%. Benicàssim i Sant Mateu superaven el 14\%, Benicarló el 13\% i per dalt del 12\% hi ha un grup de municipis format per Castelló de la Plana, Montanejos, Barracas, Cabanes de l'Arc, Santa Magdalena de Polpís i les Coves de Vinromà. Per damunt de la mitjana provincial $(9,9 \%)$ hi havien altres vuit entitats. Algunes ciutats importants de la província ocupaven 1locs significativament baixos, com ara Vila-real, la segona per nombre d'habitant però la que feia 48 per percentatge d'al·lòctons, o la Vall d'Uixó, la tercera en veïns i la que feia 69 pel pes dels nous ciutadans. En distribuir per rangs els municipis queda quantificada aquesta qüestió. 
Gràfic 8.3. Distribució dels percentatges d'al-lòctons dels municipis de Castelló a 1 de gener de 2004 segons el nombre d'habitants

$\%$ d'al loctons

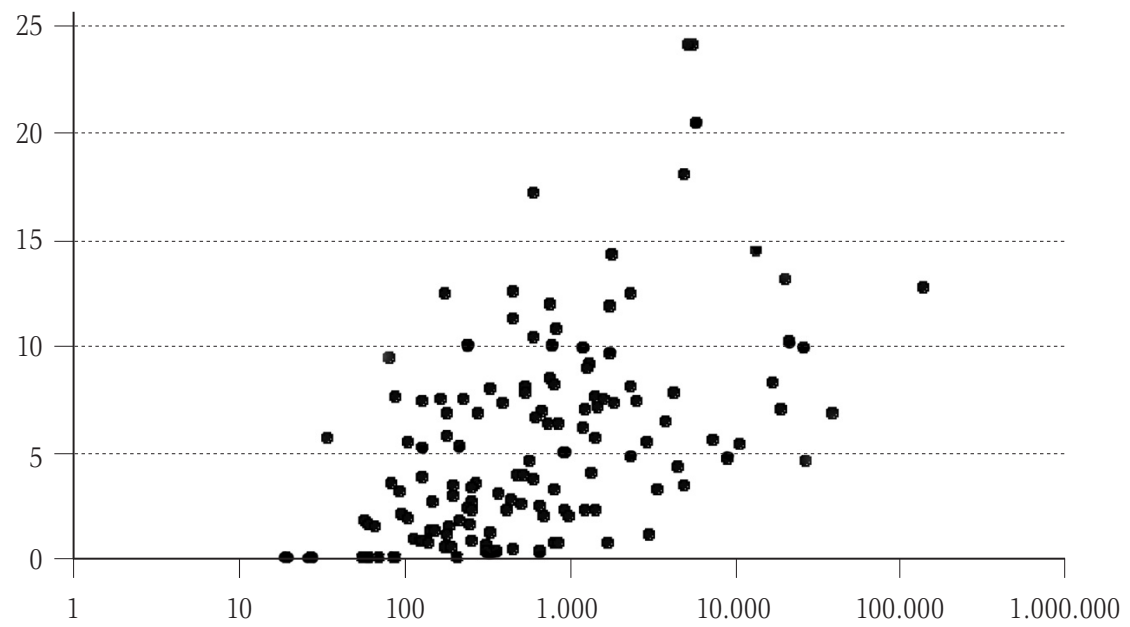

Nombre d'habitants

Font: Elaboració pròpia a partir de les dades del Padró de 2004. Instituto Nacional de Estadística.

Les que tenien una major taxa d'al-loctonia eren les petites ciutats d'entre cinc i deu mil habitants (14,4\%), i la capital provincial, on representaven el 12,9\% del seu veïnat. Molt a prop de la mitjana provincial es trobaven les ciutats que tenien entre deu i vint-i-cinc milers $(9,6 \%)$ i prou per baix hi eren les poblades entre aquesta xifra i els cinquanta mil, amb un 7,2\%, i els pobles que tenien entre cinc cents i cinc mil habitants, amb un 6,5\%. Per últim, i amb molt poca presència de nouvinguts, es trobaven les petites entitats rural, que sols en tenien un 3,8\%.

Els al-lòctons estaven lleugerament més concentrats que els autòctons en determinats indrets de la província. Així, a la capital hi vivien el 30,9\% de tota la població provincial i el 40,2\% de les persones nouvingudes; per ajuntar al 50\% de cadascun d'aquests dos collectius hi ha prou amb Castelló i Vila-real pel que fa al nous ciutadans, i fan falta tres localitats per al conjunt; 9 municipis agrupaven al 75\% de la nova població, mentre que el total provincial ho estava en 12. Des de la perspectiva comarcal també els al-lòctons eren més selectius i preferien la costa i el món urbà. 
Quadre 8.5. Distribució comarcal de la població de la província de Castelló a 1 de gener de 2004

\begin{tabular}{lccrrrr}
\hline & \multicolumn{2}{c}{ XIFRES ABSOLUTES } & & \multicolumn{2}{c}{ PERCENTATGES } \\
\cline { 1 - 3 } \cline { 5 - 6 } \cline { 5 - 6 } La Plana Baixa & AL·LÒCTONS & AUTÒCTONS & & AL·LÒCTONS & AUTÒCTONS \\
La Plana Alta & 11.142 & 160.971 & & 21,3 & 33,9 \\
L'Alcalatén & 28.842 & 197.658 & & 55,2 & 41,6 \\
L'Alt Maestrat & 750 & 15.235 & & 1,4 & 3,2 \\
El Baix Maestrat & 447 & 7.679 & & 0,9 & 1,6 \\
Els Ports & 9.553 & 62.625 & & 18,3 & 13,2 \\
El Alto Mijares & 294 & 5.305 & & 0,6 & 1,1 \\
El Alto Palancia & 151 & 3.720 & & 0,3 & 0,8 \\
Total provincial & 1.068 & 21.905 & & 2,0 & 4,6 \\
\hline
\end{tabular}

Font: Elaboració pròpia a partir de les dades del Padró de 2004. Instituto Nacional de Estadística.

La distribució espacial està influenciada per l'origen. Els europeus orientals estaven presents a 109 municipis; el procedents d'Àfrica sols s'havien domiciliat en 73 ajuntaments diferents, mentre que en una posició mitjana es trobaven els vinguts de la Unió Europea (91 entitats) i els americans (92 1locs). Si es pren en consideració que els de l'Europa de l'Est són clarament la colònia més nombrosa es lògic que arriben a més indrets, però com que hi ha més nord-africans que americans o de la Unió, sembla que els originaris d'Àfrica són menys partidaris de difuminar-se pel espai i que per fixar els seus assentaments prefereixen entitats on ja hi existeix una colònia anterior. Però la distribució espacial també depèn de molts altres factors, entre els quals, a més de l'econòmic, juga un paper fonamental l'efecte crida i assentament derivat de l'existència de xarxes migratòries. Dit d'altra manera, no simplement van on més possibilitats laborals troben, si no també on més coneixement tenen i més fàcil resulta llur primera installlació.

Analitzant l'assentament per grans grup es constata: 1) tots tenen el grup més nombrós a la ciutat de Castelló de la Plana; 2) els europeus de l'Est mostraven una preferència per la capital més acusada (54\% del total provincial, front al 35,7\% dels americans i el 26\% dels africans); i 3) els procedents de la Unió Europea, en tenir motius per migrar no purament econòmics, sols concentraven a la capital el 18\% dels seus efectius.

Si ens fixem en la quantitat d'entitats necessària per concentrar a la meitat de les persones de cadascuna de les grans àrees emissores es repeteix aquesta gradació: dels de 1'Europa del Est amb Castelló de la Plana ja hi ha prou; pels americans s'han d'agregar els de Castelló de la Plana, Benicarló 
i Vinaròs; pels ciutadans africans, a més dels de la capital s'han de sumar els de Borriana, Benicarló i Vila-real; i pels de la Unió Europea, als residents en Castelló s'han d'afegir el de Peníscola, Alcalà de Xivert i Vinaròs. Aquests exemples concrets ja apunten que, per baix del model migratori provincial es troben diferents models municipals segons les cultures d'origen dels nouvinguts. És més, fins i tot, caldria baixar a nivell de nacionalitats i municipis per fixar una imatge correcta, ja que, per exemple, a Benicarló, de entre els 1.038 africans, sols 24 no tenen nacionalitat marroquí, al temps que a Nules aquests estan en minoria front als d'altres nacionalitats africanes. ${ }^{25}$

Els models migratoris que presentaven a principis de 2004 els municipis castellonencs són molt diversos i complexes. Per tal de simplificarlos es recull a continuació la distribució percentual dels nous ciutadans, agregats segons afinitats culturals o àmbits territorials, de les 37 entitats en les quals el nombre total d'immigrants era superior al centenar (constituien el 96\% de tots els de la província), i organitzats segons tres tipologies. ${ }^{26}$

En primer 1loc, aquelles entitats en les quals hi havia un clar predomini d'un àmbit territorial (més de la meitat), a continuació on entre dos suposaven al menys dos de cada tres nous aveïnats del municipi, i per últim, els pobles on es donava un equilibri entre les diferents adscripcions dels nouvinguts.

Els qui provenien dels quatre grans territoris mostraven una clara tendència a concentrar-se en determinats indrets, de manera que adquirien un marcat protagonisme en els municipis seleccionats. En nou entitats locals predominaven les persones de l'Europa de l'Est, en dues els africans i en una els americans i els europeus de la Unió. Però aquest model de concentració es difumina lleugerament per que en altres entitats eixa posició capdavantera era compartida per dues àrees d'origen.

Seguien sent més els llocs de clar predomini dels ciutadans de l'Europa de l'Est, amb totes les combinacions possibles, en concordància amb el fet de que en el total provincial n'eren molts més, però els originaris de les

25 També entre els 1latinoamericans els contrastos nacionals són significatius. Així, els naturals de Colòmbia són molt més nombrosos que el d'Equador a Castelló de la Plana, Vilareal, Benicàssim, Segorbe, la Vall d'Uixó, Borriana i altres localitats de les comarques centrals, en canvi a Benicarló, Vinaròs i Peníscola la situació és a l'inrevés.

${ }^{26}$ Les dades publicades per 1'Instituto Nacional de Estadística del Padró de 2004 sols tenen en comte, per cada municipi, 16 àmbits territorials d'origen dels nouvinguts. 
Quadre 8.6. Distribució percentual dels al·lòctons als municipis on un origen era majoritari i que en total tenien aveïnats més de 100 nouvinguts. Dades d' 1 de gener de 2004

\begin{tabular}{lccrrr}
\hline Predomini de $\ldots$ & UNIÓ EUROPEA & RESTA D'EUROPA & ÀFRICA & AMĖRICA & TOTAL \\
\hline $\begin{array}{l}\text { La Unió Europea } \\
\text { Alcalà de Xivert }\end{array}$ & 51,2 & 12,5 & 28,0 & 7,3 & 1.341 \\
\hline L'Europa de 1'Est & & & & & \\
Castelló de la Plana & 5,5 & 61,5 & 13,8 & 16,9 & 21.026 \\
Torreblanca & 8,0 & 65,2 & 22,8 & 4,1 & 993 \\
Sant Mateu & 1,1 & 52,7 & 43,1 & 3,2 & 283 \\
Morella & 3,4 & 84,6 & 0,0 & 12,0 & 208 \\
Betxí & 5,7 & 65,1 & 12,0 & 17,2 & 192 \\
Viver & 3,8 & 84,6 & 0,0 & 11,5 & 130 \\
Rosell & 6,2 & 76,0 & 5,4 & 12,4 & 129 \\
Albocàsser & 0,0 & 59,5 & 27,0 & 13,5 & 126 \\
Traiguera & 10,0 & 71,7 & 15,8 & 2,5 & 120 \\
\hline Àfrica & & & & & \\
Les Coves de Vinromà & 3,5 & 25,2 & 58,8 & 12,4 & 226 \\
Sant Joan de Moró & 10,2 & 10,7 & 68,4 & 9,1 & 187 \\
\hline Amèrica & & & & & \\
Segorbe & 7,5 & 15,9 & 4,1 & 69,0 & 465 \\
\hline
\end{tabular}

Font: Elaboració pròpia a partir de les dades del Padró de 2004. Instituto Nacional de Estadística.

altres zones també manifestaven una ferma decisió de residir allà on ja abans hi viuen gent dels seus mateixos països. En canvi, és relativament reduit el nombre d'entitats i el volum total d'estrangers que acullen els municipis en els quals els nouvinguts es distribueixen proporcionalment segons llur origen.

Les característiques socioeconòmiques comunes dels llocs triats per cada colònia, excepte en el cas dels immigrants rics que clarament es decanten per la costa centre-nord, no permeten constatar amb nitidesa altres factors que puguen explicar les decisions d'on residir, com no siga acollir-nos a la hipòtesi de les xarxes migratòries. Segons el tamany de les entitats s'ha produit una certa concentració de preferències.

Així els europeus de l'Estat del benestar viuen en un 60\% a les ciutats intermèdies (de 5.000 a 25.000 habitants); els de l'Europa de 1'Est, com ja s'ha observat, es decanten majoritàriament per la capital; els africans estan relativament poc representat a aquest municipi i semblen buscar un lloguer més barat o/i la proximitat al treball agrícola que ofereixen la resta de ciutats i els pobles mitjans; i els americans es distribueixen en un terç a Castelló de la Plana, un altre terç a les ciutats entre u i dos i mig desenes de milers de veïns, i uns altres tants s'escampen per la resta de la província. 
Quadre 8.7. Distribució percentual dels al·lòctons als municipis on dues de les àrees d'origen eren majoritàries i que en total tenien aveïnats més de 100 nouvinguts.

Dades d'1 de gener de 2004

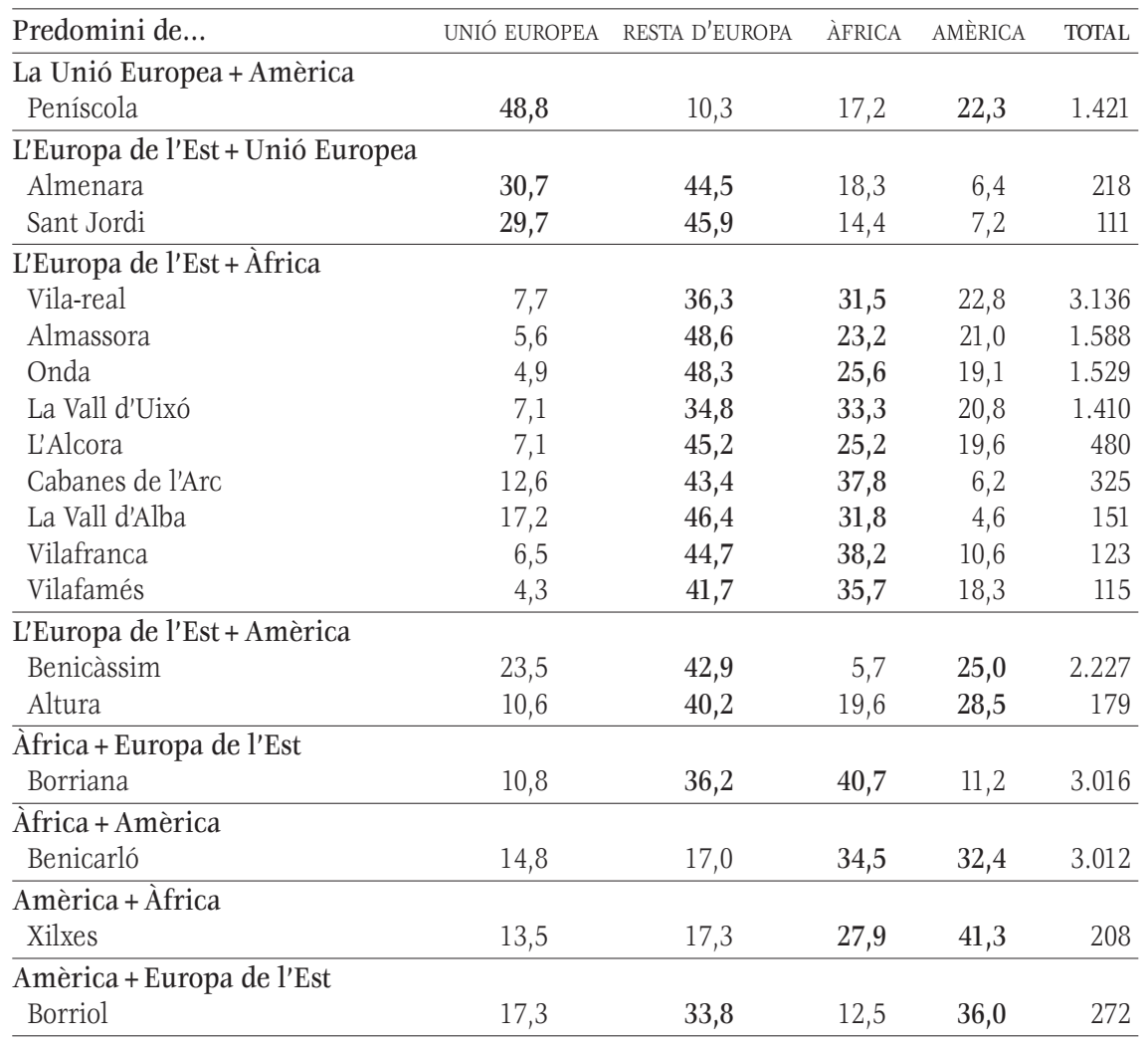

Font: Elaboració pròpia a partir de les dades del Padró de 2004. Instituto Nacional de Estadística.

Quadre 8.8. Distribució percentual dels al·lòctons als municipis on dues de les àrees d'origen no eren majoritàries i que en total tenien aveïnats més de 100 nouvinguts.

Dades d'1 de gener de 2004

\begin{tabular}{lcccrr}
\hline Model d'equilibri & UNIÓ EUROPEA & RESTA D'EUROPA & ÀFRICA & AMÈRICA & TOTAL \\
\hline Càlig & 33,6 & 29,8 & 22,1 & 3,8 & 131 \\
Orpesa del Mar & 22,5 & 33,4 & 22,2 & 20,3 & 1.510 \\
Moncofa & 26,3 & 20,1 & 37,7 & 13,6 & 369 \\
Nules & 19,1 & 29,1 & 33,6 & 14,8 & 649 \\
Les Alqueries de la Plana & 23,6 & 21,1 & 23,6 & 31,7 & 123 \\
Vinaròs & 26,3 & 22,8 & 19,1 & 30,1 & 2.525 \\
\hline
\end{tabular}

Font: Elaboració pròpia a partir de les dades del Padró de 2004. Instituto Nacional de Estadística. 


\section{Sex ratio i estructura per edats}

Els fluxos migratoris sempre són selectius en funció, entre molts altres paràmetres, del sexe. Històricament les emigracions solien ser majoritàriament masculines i els processos de retrobament familiar eren poc freqüents. En l'actualitat el predomini d'un gènere o de l'altre en els desplaçaments varia segons les cultures d'origen i, amb major o menor retard, es sol produir, amb gran intensitat, la incorporació de la parella, els fills i fins $i$ tot els pares $i$ altres familiars al projecte migratori del pioner. Per aquests motius les relacions de masculinitat dels nous ciutadans varia significativament al llarg del temps i els territoris considerats. A la província de Castelló, a 1 de gener de 2005 la sex ratio dels alllòctons era de 120,4, mentre que la de la població autòctona era del 98,2.

Per nacionalitats les diferències són altament significatives: les colònies amb majors desequilibres per sexes eren les dels procedents del nord d'Àfrica, ja que de cada dona hi han dos homes; a l'altre extrem es situen les que han arribat del sud d'Amèrica, amb clar predomini de les dones, en una proporció de quatre a tres; relativament prou equilibrats estan els colllectius dels europeus de la Unió $(118,8)$ i de Romania $(113,7)$. Fixar-se en l'evolució en els darrers anys d'aquest indicador aporta alguna llum respecte de l'estat en el que es troben els projectes migratoris familiars.

Com mostra la figura 5 des de l'any 2002 les principals comunitats tendeixen a anivellar-se per sexes, excepte les dels procedents de la Unió Europea. Açò fa pensar que sense haver-se esgotat l'arribada de pioners també estan arribant les seves parelles i fills dels que ja porten aquí alguns anys. Per altra banda, també és pot mantenir la hipòtesi que, fins i tot en el supòsit de que no en vingueren més a treballar aquí i es consolidaren els que ja hi son, el procés d'arribades continuaria potent sols pel reagrupament.

El detall d'alguns orígens també reflexa particularitats interessants: 1) dels comunitaris són Itàlia i Portugal, dues de les colònies més recents, els que desequilibren, per la seva masculinitat, la sex ratio de la Unió, ja que francesos, alemanys, anglesos i belgues estan pròxims a la centena; 2) la majoria dels antics països comunistes presentes taxes moderades $i$ semblants entre si menys Rússia, país del qual hi ha quasi tres dones per cada dos homes; 3) entre els nord-africans, els marroquins, assentats aquí des de fa més temps, tenen un índex menys exagerat que els argelins, que són més recents; 4) dels arribats de més enllà de l'Atlàntic, d'argentins, 
Gràfic 8.4. Evolució anual de la relació de masculinitat d'algunes comunitats d'al·lòctons a la província de Castelló, 1996-2005

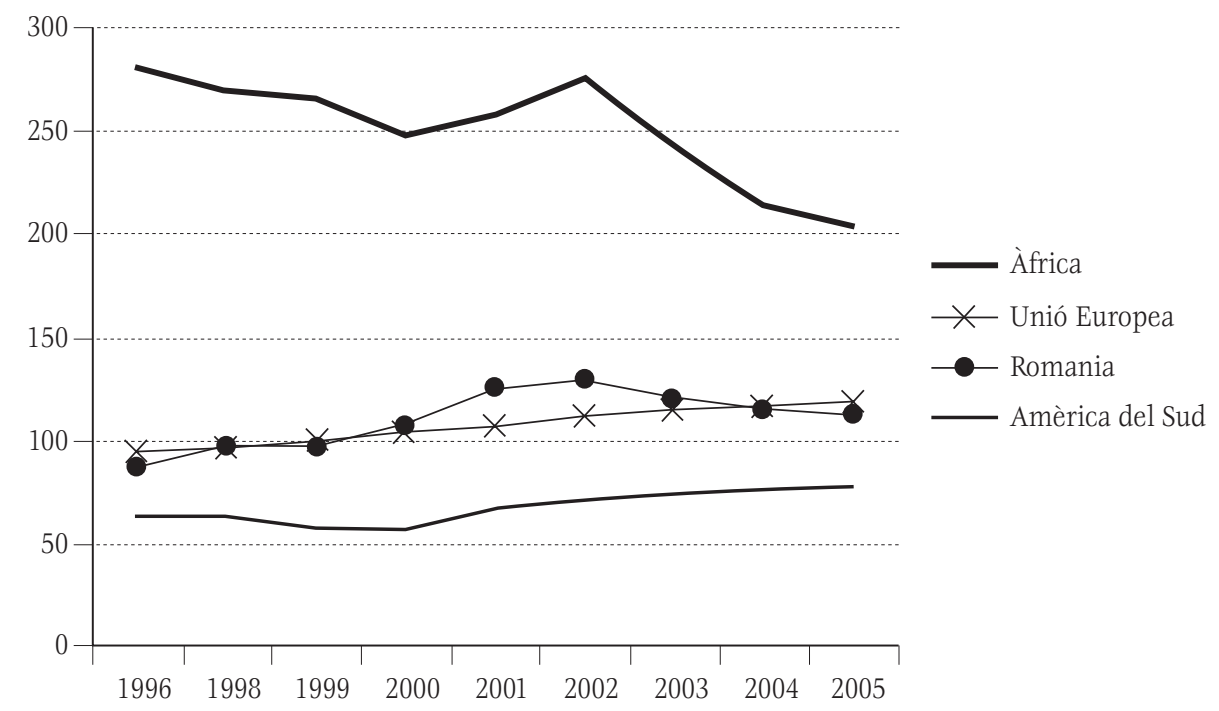

Font: Elaboració pròpia a partir de les dades del Cens de 1991, padrons i rectificacions de 1996, 1998, 1999, 2000, 2001, 2002, 2003, 2004 i xifres provisionals del Padró de 2005. Instituto Nacional de Estadística.

equatorians i peruans hi ha quantitats semblants per cada sexe, mentre que són més abundants les colombianes, però també les cubanes, veneçolanes i brasileres.

Les diferències per sexe dels alllòctons canvia segons els grups d'edat. Per al conjunt dels nous ciutadans el predomini masculí sols es produeix a l'etapa laboral, en concret entre els 25 al 49 anys. A les etapes infantil, juvenil i de senectut els contrastos no són estadísticament significatius. Per països torna a destacar-se i de manera més exagerada els desequilibris en els grups centrals. Així, dels argelins compresos entre 25 i 49 anys per cada dona hi ha quatre homes, al temps que de brasileres de 25 a 29 anys hi ha quatre per cada home. Els romanesos presenten una sex ratio per edats resultat combinat de que la masculinització de la emigració és entre ells moderada ${ }^{27} \mathrm{i}$ de que s'està reduint gràcies a que l'èxit assolit per molts d'ells en el seu projecte migratori els ha permès que arribara la seva parella.

27 Segons Constantin (2004) durant el període comprés entre 1975 i 2003, de les 711.000 persones que «oficialment» van emigrat, el 52\% eren dones. 
Quadre 8.9. Distribució per grans grups d'edats de diferents col·lectius de la població de la província de Castelló en 2004

\begin{tabular}{|c|c|c|c|c|c|c|c|c|c|}
\hline & & & & & UNIÓ & AMÈRICA & & & \\
\hline & ROMANIA & ÀFRICA & ÀSIA & EQUADOR & EUROPEA & DEL SUD & AL'LÒCTONS & AUTÒCTONS & TOTAL \\
\hline$\overline{0-14}$ & 13,0 & 17,2 & 17,9 & 22,5 & 9,7 & 18,6 & 14,5 & 14,1 & 14,2 \\
\hline $15-64$ & 86,6 & 81,9 & 79,5 & 77,2 & 75,1 & 79,8 & 82,8 & 67,3 & 68,9 \\
\hline $65 i+$ & 0,4 & 0,8 & 2,6 & 0,2 & 15,3 & 1,5 & 2,7 & 18,5 & 17,0 \\
\hline
\end{tabular}

Font: Elaboració pròpia a partir de les dades del Padró de 2004. Instituto Nacional de Estadística.

És per això que sols als grups de 25 a 39 anys la relació de masculinitat supera el 120, mentre que els menors estan distribuits per igual i entre els més adults s'evidencia la major longevitat femenina.

Els desequilibris entre els sexes d'algunes comunitats, en la mesura en la qual les relacions personals interculturals encara són escasses, comporta conseqüències per a les persones d'aquests grups, ja que enrareix el mercat matrimonial i obliga a desplaçar vers amunt i vers baix pels grups d'edat la demanda per constituir parelles aquí.

Pel que fa al mercat laboral, influenciat directament per les conseqüències d'un fenomen fonamentalment econòmic com el migratori, la divisió de la població en tres grans grups és molt significativa, ja que permet diferenciar de manera precisa i ràpida la població potencialment activa de la inactiva. L'anàlisi de les dades disponibles respecte a aquest punt revela que, d'una banda, el percentatge de ciutadans en edat laboral és major entre els alllòctons; també que a les comunitats procedents de les àrees menys desenvolupades, és a dir, la "immigració econòmica", hi ha més persones en aquestes edats que entre els arribats del primer mon; i d'altra banda, també hi ha grans diferències segons l'àrea geogràfica de procedència: les originàries d'Europa occidental tenen els valors més baixos. Asiàtics i llatinoamericans estan uns pocs punts per baix de la mitjana, els africans quasi la igualen i sols els romanesos destaquen per dalt clarament.

Els nous ciutadans arribats als darrers anys a la província permeten apuntalar la base de la piràmide, eixamplar significativament el cos dels adults i alleugerir-la, també amb força, del pes proporcional de les persones de la tercera i quarta edat. La imatge del detall de la distribució per cohorts quinquennals d'autòctons i al-lòctons mostra els beneficis demogràfics de les arribades per a una societat com la castellonenca, tan avançada en el procés d'envelliment. 
Gràfic 8.5. Estructura per edat i sexe de la població autòctona de la província de Castelló a 1 de gener de 2004

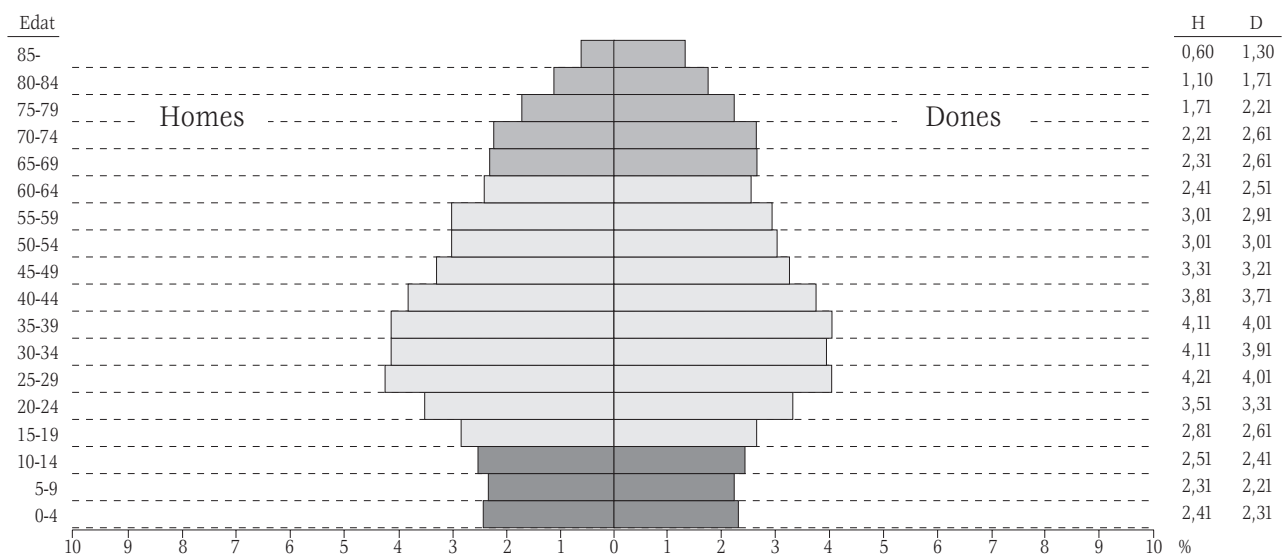

Font: Elaboració pròpia a partir de les dades del Padró de 2004. Instituto Nacional de Estadística.

Gràfic 8.6. Estructura per edat i sexe de la població al·lòctona de la província de Castelló a 1 de gener de 2004

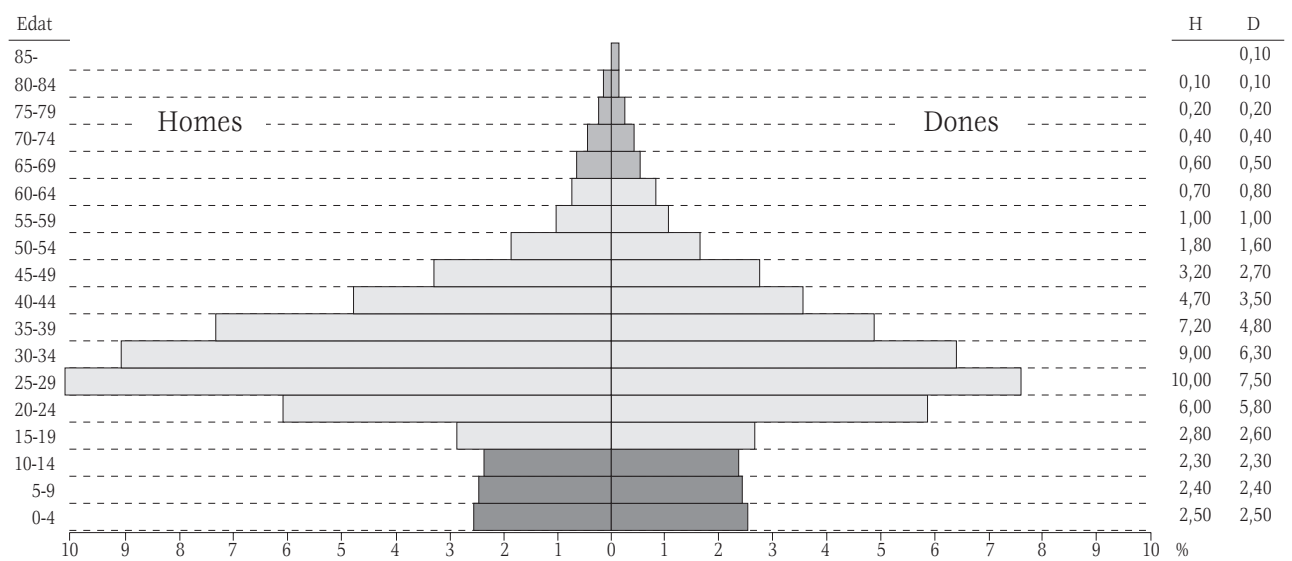

Font: Elaboració pròpia a partir de les dades del Padró de 2004. Instituto Nacional de Estadística. 
Gràfic 8.7. Distribució per grups d'edat quinquennals dels romanesos i dels autòctons de la província de Castelló a 1 de gener de 2004

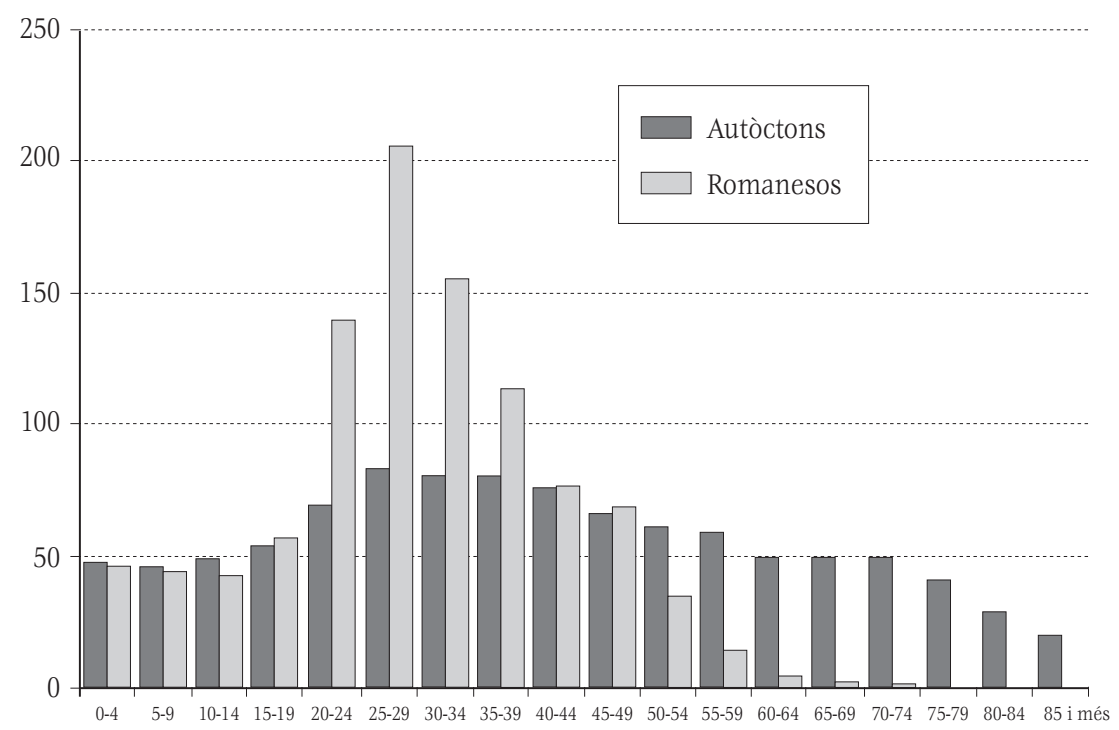

Font: Elaboració pròpia a partir de les dades del Padró de 2004. Instituto Nacional de Estadística.

Les peculiaritats demogràfiques de la societat romanesa i dels ritmes de les arribades dels seus emigrants a la província de Castelló han deixat la seva empenta en el perfil de la piràmide d'aquesta colònia a la província. Així, pel que fa als menors es combina el tractar-se d'un país amb una moderada natalitat i el que encara porten pocs anys entre nosaltres, per la qual cosa els percentatges de joves són quasi igual als de la població autòctona. Per contra, en ser un flux que busca treball, el predomini de les persones en edat laboral era aclapadora i es concentrava entre els 20 i els 34 anys, ja que per als més majors prendre la decisió d'eixir del seu país és més costosa i tenen menys probabilitats de trobar feina en el lloc de destí. I, perquè el procés de reagrupament familiar, respecte als ascendents del pioner, encara es troba en els primers estadis, i al mateix temps per tenir Romania una piràmide menys envellida que la nostra, els percentatges de persones que ja han complit el seu seixanta-cinc aniversari domiciliades a les nostres comarques és molt baix.

Per fer més paleses les diferències entre les estructures d'edat de la colònia de romanesos i els autòctons de la província hi ha prou en dir que 
l'edat mitjana d'aquells està lleugerament per baix dels 30 anys, mentre que la dels autòctons és de 41; o mentre que entre aquests hi ha 1,3 persones majors de 65 anys per cada menor de 15 anys, entre els romanesos aquesta proporció és sols de 0,03. Encara que és evident que a mesura que es consoliden els processos de reagrupament familiar aquestes xifres tendiran a moderar-se.

\section{Nivells de formació del capital humà}

Una de les característiques de la nova migració és que no sols es mouen les capes més baixes econòmicament ni les menys preparades de les societats d'origen. Lanàlisi de la formació a partir del Cens 2001 confirma aquest punt: ${ }^{28}$ els estudis que declaraven els nous ciutadans són mitjans-alts i l'anàlisi per nivells d'estudis presenta característiques que ja s'han avançat en treballs anteriors (Izquierdo, 2001):29 1) reduit percentatge de població analfabeta; 2) majoria de població amb estudis de secundària (ESO, EGB, batxillerat i FP); 3) un grup elevat dels censats tenen nivells universitaris. Com que la província de Castelló tradicionalment ha tingut una formació baixa dintre de l'àmbit estatal, no és d'estranyar que segons el Cens de 2001 els percentatges al-lòctons d'analfabets, sense estudis i sols amb el primer grau, eren clarament inferiors als de la població autòctona. Per contra, els nouvinguts destacaven per que el $48 \%$ havia cursats estudis de segon grau front al 39,6\% dels espanyols. Sols en els nivells universitaris tenia un avantatge la comunitat autòctona, (8,8\%) envers el (6,8\%). Aquestes dades contradiuen la imatge molt estesa socialment i recollida també en els documents oficials que «son personas... con altos índices de analfabetismo y escasa calificación profesional...» (Programa Greco 2001).

Per tant, des de la perspectiva del capital humà, al menys en teoria, sembla que els domiciliats aquí a les darreries del 2001 els alllòctons gaudien d'uns nivells d'estudis més apropiats per a les ofertes del mercat laboral local que els ciutadans espanyols.

28 Malauradament, per poder conèixer els trets demogràfics que s'analitzen als fulls següents no es poden emprar els padrons municipals i ens hem de retraure a la data censal d'1 de novembre de 2001.

29 En aquesta ponència i utilitzant els expedients de regularització de l'any 2000, Antonio Izquierdo (catedràtic de Sociologia de la Universitat de la Corunya), dóna uns nivells de formació de $28 \%$ dels al:lòctons amb estudis d'EGB, $41 \%$ amb estudis secundaris i 17\% amb estudis universitaris. 
Gràfic 8.8. Distribució percentual de la població autòctona i al·lòctona de la província de Castelló en 2001 segons els seus nivells d'estudis

\section{Percentatge}

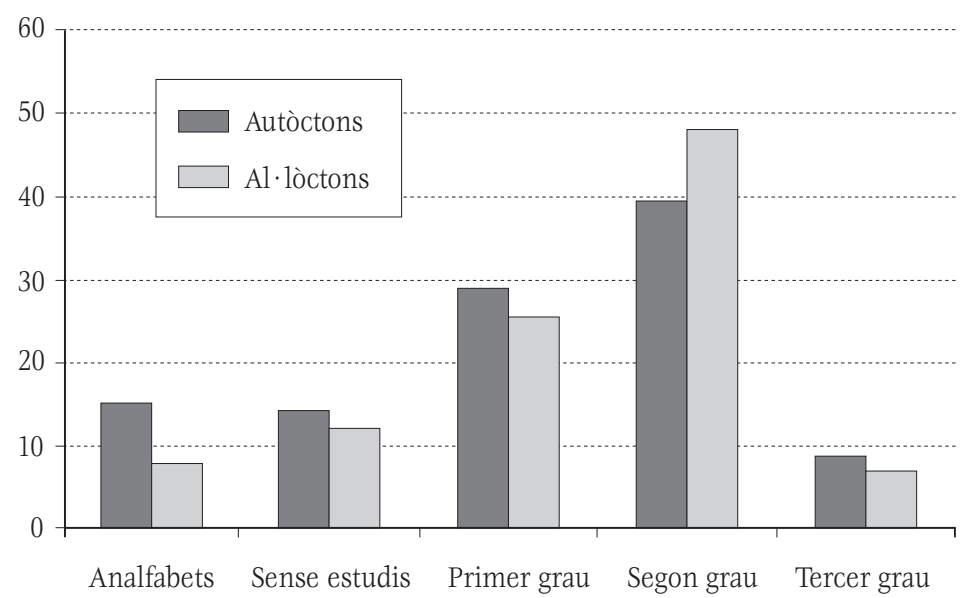

Font: Elaboració pròpia a partir de les dades del Cens d'1 de novembre de 2001. Instituto Nacional de Estadística.

Però l'afirmació anterior s'ha de matisar prou donat que: 1) l'envelliment dels dos colllectius és radicalment oposat i fa baixar significativament el nivell mitjà de formació dels autòctons; 2) els nouvinguts solen ocupar llocs de treball poc qualificats per als estudis que han cursat, la qual cosa fica de manifest que estudis i habilitats professionals no sempre mantenen, o al menys els empleadors no els reconeixen, una relació directa; i 3) no som receptor de fluxos de científics ni d'informàtics que, selectivament, estan demandant altres socis comunitaris (Alemanya, França, Anglaterra) des dels països menys desenvolupats. ${ }^{30}$

Els contrastos entre els diferents colllectius alllòctons en la formació eren molt grans. Agrupant-los segons el nivell de benestar dels seus països d'origen, els originaris dels països amb estats de benestar més desenvolupats tenien el nivell de formació més alt, doncs: 1) hi havia menys

30 Aquest «brain drain» és enormement contradictori, doncs d'una banda permet al receptor no sols disposar d'un personal altament qualificat a cost "zero" (s'han format al emissor), si no també compensar la seua «fuga de serveis» cap a USA i Xina, fonamentalment. I, per altre costat, en principi, encara que no hi ha acord al respecte (Stark, 2003; Beine et altres, 2001; Faini, 2002), constitueix una pèrdua per a l'emissor. Aquesta diferència respecte a altres socis comunitaris és una conseqüència lògica i una de les causes explicatives del retard tecnològic i científic del nostre aparell productiu. 
analfabets, sense estudis i sols amb el primer grau; 2) més de la meitat dels nouvinguts havien superat estudis de batxillerat o formació professional; i 3) el percentatge de titulats universitaris $(12,6 \%)$ era superior. Però tampoc existia una correlació significativa entre nivell de renda per càpita i el grau de formació. Així, prenent en consideració les colònies que a 1 de novembre de 2001 tenien domiciliats al menys a cent persones a la província s'observa que presentaven majors percentatges d'analfabets els collectius vinguts de Marroc, Xina, Algèria i Equador, i també tenien taxes més elevades de ciutadans sense estudis, a més dels anteriors, la República Dominicana, Ucraina i Veneçuela. En aquestos casos es compleix la hipòtesi lògica de connexió entre pobresa i d'endarreriment cultural. Però a l'altre extrem, es a dir, els països que menys immigrants poc formats ens han enviat són Cuba, Holanda, Eslovàquia, Regne Unit i Uruguai. Si en 1loc de mirar per baix ens centrem en els trams més elevats del sistema educatiu i considerem conjuntament a la població que ha cursat estudis de segon (els equivalents a EGB, ESO, Batxillerat i Formació Professional) o de tercer grau (Diplomatura, Llicenciatura i Doctorat) els nouvinguts millor preparats són, per aquest ordre, holandesos, cubans, russos, italians, eslovaquians, xilens i anglesos. Per tant, alguns països americans o de l'Est aportaven capital humà més format que socis nostres de la Unió com França, Alemanya o Bèlgica. I entre les quatre nacionalitats amb menors percentatges d'individus amb alta formació, a més de Marroc, Xina i la República Dominicana, es troba Portugal.

Per la seva especial significació convé destacar les dades que presentaven els romanesos. A finals del 2001 tenien un nivell de formació elevat i molt orientat a les necessitats del mercat laboral, ja que les persones que no havien completat els nivells d'estudis obligatoris, es a dir, que no tenien els coneixements assimilables al que en el nostre sistema seria l'EGB, l'ESO o l'antic batxillerat sols eren el 38,4\%, percentatge clarament inferior al 45,1\% del conjunt dels nous ciutadans o al 51,6\% dels autòctons. El sistema educatiu d'aquest país centro-europeu dels últims anys de Nicolai Ceaucescu va prioritzar les formacions tècniques, per la qual cosa el que al Cens es denomina segon grau és el nivell que declaren tenir el 57,2\% dels ciutadans de Romania, xifra ben allunyada del 48,1\% del conjunts dels al-lòctons i del 39,4\% dels espanyols. Per contra, de titulats universitaris entre els romanesos aquí installats, almenys en aquella data, no hi havia molts.

Segons l'anàlisi dels resultats de l'enquesta del Departament d'Economia de la Universitat Jaume I, abans esmentada, el perfil educatiu dels 
ciutadans romanesos instal-lats a Castelló dóna uns resultats millors que l'explotació de les dades censals, i molt semblant a les xifres que s'extrauen dels estudis d'autor romanesos sobre la seua emigració, els quals avaluen entre un 10-12\% del total el percentatge de personal altament qualificat (formació superior) que deixa el país; en un 25\% els que tenen estudis secundaris i aproximadament un 33\% els que posseeixen estudis de Batxi1lerat (Constantin, 2004). ${ }^{31}$ És a dir, un perfil mitjà-alt, normal d'altra banda en una població europea.

El conjunts dels nouvinguts presentava uns nivells de formació molt equilibrats per sexe, fins i tot un poc més que la població autòctona, amb un molt lleuger avantatge per les dones, ja que si bé el percentatge d'analfabetes era un punt superior al dels homes, en passar al grup de sense estudis el diferencial les afavoria a elles, amb la qual cosa als nivells inferiors d'estudis ambdós sexes estaven igualats. Si es consideren les persones que havien superar el segon grau i les que posseïen un títol universitari es trobaven més dones que barons.

Per orígens també es presenten contrastos significatius, podent-se establir diferents tipologies. Així, entre les colònies en les quals les dones han estat més marginades respecte del sistema educatiu destaca la marroquina, però també entre els ciutadans alemanys i els italians hi ha més homes amb Batxillerat i similars i universitaris que dones, al temps que entre elles hi ha més sense estudis i analfabetes. A l'altre extrem es situen els vinguts de Colòmbia, dins dels quals la dona gaudeix de una destacada millor formació. Un tercer model el constituirien els equatorians, algerians i francesos, entre els quals hi havien més universitàries, però també menys formades, en destacar els homes amb titulacions de segon grau. I una quarta tipologia seria la dels romanesos, que es podria qualificar com extremadament equilibrada, ja que les diferències del pes de cadascun dels grups segons el sexe i el nivell d'estudis són mínimes i fluctuants a mesura que es canvia de nivell.

\section{L'estat civil i estructura de la llar}

El colllectiu d'alllòctons presentava en el Cens de l'any 2001 un 1leuger predomini de la població soltera (11.496) sobre la casada (10.778), que s'incrementaria si es consideren als vidus (467), als separats (500) i als

31 Constantin (2004), opus cit., p. 74. 
Quadre 8.10. Distribució per sexe, grup d'edat i estat civil dels al·lòctons i dels romanesos a 1 de novembre de 2001. Xifres absolutes y percentuals

\begin{tabular}{|c|c|c|c|c|c|c|c|}
\hline & \multicolumn{3}{|c|}{ Conjunt d'al·lòctons } & \multicolumn{3}{|c|}{ Romanesos } \\
\hline & & FADRINS & CASATS & $\mathrm{V}+\mathrm{S}+\mathrm{D}$ & FADRINS & CASATS & $V+S+D$ \\
\hline \multirow[t]{4}{*}{ Homes } & $20-29$ & 2.774 & 1.062 & 32 & 914 & 446 & 8 \\
\hline & $30-39$ & 1.301 & 2.446 & 131 & 276 & 786 & 41 \\
\hline & $40-49$ & 294 & 1.347 & 119 & 63 & 475 & 31 \\
\hline & $50 \mathrm{i}+$ & 143 & 972 & 186 & 14 & 144 & 5 \\
\hline \multirow[t]{6}{*}{ Dones } & $20-29$ & 1.566 & 1.491 & 102 & 522 & 528 & 37 \\
\hline & 30-39 & 702 & 1.665 & 251 & 188 & 541 & 66 \\
\hline & $40-49$ & 250 & 1.000 & 236 & 65 & 361 & 89 \\
\hline & $50 \mathrm{i}+$ & 99 & 740 & 409 & 11 & 84 & 50 \\
\hline & & \multicolumn{3}{|c|}{ \% Conjunt d'al·lòctons } & \multicolumn{3}{|c|}{ \% Romanesos } \\
\hline & & FADRINS & CASATS & $v+S+D$ & FADRINS & CASATS & $V+S+D$ \\
\hline \multirow[t]{4}{*}{ Homes } & $20-29$ & 71,72 & 27,46 & 0,83 & 66,81 & 32,60 & 0,58 \\
\hline & 30-39 & 33,55 & 63,07 & 3,38 & 25,02 & 71,26 & 3,72 \\
\hline & $40-49$ & 16,70 & 76,53 & 6,76 & 11,07 & 83,48 & 5,45 \\
\hline & $50 \mathrm{i}+$ & 10,99 & 74,71 & 14,30 & 8,59 & 88,34 & 3,07 \\
\hline \multirow[t]{4}{*}{ Dones } & $20-29$ & 49,57 & 47,20 & 3,23 & 48,02 & 48,57 & 3,40 \\
\hline & 30-39 & 26,81 & 63,60 & 9,59 & 23,65 & 68,05 & 8,30 \\
\hline & $40-49$ & 16,82 & 67,29 & 15,88 & 12,62 & 70,10 & 17,28 \\
\hline & $50 \mathrm{i}+$ & 7,93 & 59,29 & 32,77 & 7,59 & 57,93 & 34,48 \\
\hline
\end{tabular}

Font: Elaboració pròpia a partir de les dades del Cens de 2001. Instituto Nacional de Estadística.

divorciats (504) com no-casats. Per sexes tenen significatives diferències, ja que si en el total hi havien 2.379 més homes que dones, sols de fadrins n'hi havia 2.204 més que de fadrines, mentre que entre els casats la diferència, també a favor dels barons, era sols de 888, i eren més nombroses les vídues, les separades i les divorciades. En termes proporcionals hi havia més fadrins $(51,8 \%)$ que casats $(44,7 \%)$, mentre que entre elles predominaven les casades (46,3\%) front a les solteres (44,3\%). En la resta de situacions possibles d'estat civil d'homes hi havia pocs ( $0,7 \%$ de vidus i $2,9 \%$ amb matrimoni trencat) mentre que entre les dones els percentatges ja eren significatius (3,6\% vídues i 5,8\% de separades o divorciades). Aquesta primera aproximació, sense desagregacions segons edats ni orígens, ja confirmava que els moviments migratoris són molts selectius segons el sexe i els compromisos familiars, i que generen en els llocs d'arribada forts desequilibris i situacions transitòries o d'escassa estabilitat familiar. Però com que l'estat civil està directament condicionat per l'edat, és necessari baixar a aquell nivell l'anàlisi per mesurar fins a quin punt el pes de les estructures per aquest indicador estava condicionant les xifres anteriors. 
Com era de esperar, entre els adults més joves hi havia un clar predomini dels solters damunt dels casats, però a mesura que s'eleva l'edat es tendia a la situació contrària, i al mateix temps s'incrementaven les persones que havien vist trencat el seu matrimoni. Però els alts percentatges de fadrins i fadrines amb més de 30 anys d'edat demostra que les migracions, sense ser exclusives, sí que són més probables entre les persones que tenen aquest estat civil. Per grups d'edat els contingents de fadrins eren molt superiors als de les xiques, generant-se en les societats de destí forts desequilibris en els ja restringits mercats matrimonials (les parelles entre membres de distintes colònies o entre els nouvinguts i els autòctons encara tenen poca significació estadística). Entre els adults majors de 50 anys d'edat el celibat estava poc representat, ja que la majoria eren casats, però mentre en aquestes dues situacions eren més abundants els homes, elles ho eren en la situació de vídues, separades i divorciades.

Les estructures segons l'estat civil també són ben contrastades en funció de l'origen dels nous ciutadans de Castelló. A grans trets es pot dir que els procedents de la Unió Europea presenten un major percentatge de casats, seguits de prop pels romanesos, mentre que africans i sud-americans tenen majors taxes de solteria.

Les estructures familiars i de les llars dels nous vinguts també reflectien la selecció que imposa el fet de l'emigració i les condicions econòmiques, socials i de l'habitatge que es troben en els llocs de destí. En la majoria dels casos el primer trasllat l'efectua un sol membre de la família amb una perspectiva temporal determinada, però si el projecte no fracassa hi ha moltes probabilitats que l'emigració de temporal es converteixi en definitiva i que es produeixi un procés de reagrupament familiar, primer la nuclear i, en moltes ocasions, fins i tot l'extensa o, al menys, una part dels nuclis de la parentela. Per tant, l'anàlisi de les composicions de famílies i llars dels nouvinguts dona llum sobre el nivell de dispersió o d'agrupament dels al-lòctons i, per tant, permet previsions de contingents futures.

La baixa capacitat adquisitiva dels nouvinguts (emigració econòmica), l'alt preu dels lloguers i la voluntat d'estalviar els força, en moltes ocasions, a compartir una mateixa llar amb persones que en els seus països d'origen mai no ho farien. Però, per altra banda, la migració separa temporalment els membres de les famílies dels pioners i el reagrupament complet o es retarda o no es produeix mai. Entre tant, els models de cohabitació que assoleixen els nouvinguts també difereixen dels propis de la seva 
Gràfic 8.9. Distribució percentual dels habitants de la província de Castelló en 2001, segons el nombre de persones per llar i diferenciant entre autòctons i alllòctons

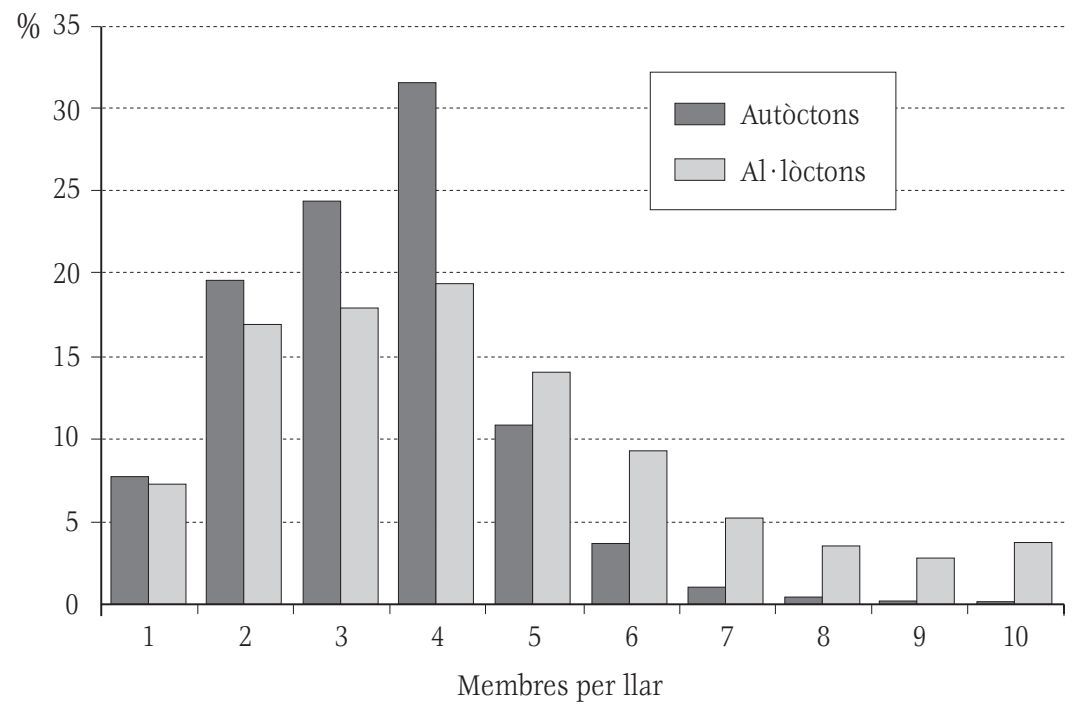

Font: Elaboració pròpia a partir del Cens d'1 de novembre de 2001. Instituto Nacional de Estadística.

cultura i tendeixen, si hi ha una mínima disponibilitat financera, a generar tamanys de les llars inferiors a les tradicionals en les seves societats. Per aquests motius el nombre mitjà d'individus per habitatge dels al-lòctons $(3,05)$, encara sent més gran que el dels autòctons $(2,7)$, no aplega a xifres exagerades. Hi ha una clara diferència entre un i l'altre grup en analitzar els rangs, doncs els percentatges de llars al-lòctones amb menys de cinc membres són menors, mentre que als rangs superior a cinc el predomini dels nouvinguts és aclaparador. Dit d'un altra manera, entre els autòctons el 83,6\% de les persones vivien en llars amb quatre o menys membres, mentre que entre els al-loctons aquest percentatge es reduïa al $61,4 \%$.

La riquesa informativa que ofereix el Cens de 2001 permet analitzar els models corresidencials tant des de l'òptica de les familiars extenses ${ }^{32}$ com de les famílies nuclears. ${ }^{33}$

32 L'ine defineix el concepte de família com un grup de persones que resideixen en un mateix habitatge i que estan vinculades per alguna mena de lligam de parentiu, ja siga de sang o polític, independentment del grau

${ }^{33}$ El que l'INE anomena nuclis, es a dir, parella sense fills o amb fills i pare o mare amb fills, sempre que aquestos no tinguen la seva pròpia parella ni descendents. 
Quadre 8.11. Distribució percentual dels habitants de la província de Castelló en 2001, segons el model corresidencial i diferenciant entre autòctons i al-lòctons

\begin{tabular}{lcc}
\hline$\%$ D'HABITANTS EN LLARS & AL·LÒCTONS & AUTÒCTONS \\
\hline Sense família & 14,7 & 8,3 \\
1 família sense nucli & 9,1 & 1,8 \\
Sense nucli & 23,8 & 10,1 \\
1 família amb 1 nucli & 65,0 & 86,0 \\
1 família amb 2 o més nuclis & 1,9 & 3,2 \\
1 família & 76,0 & 91,1 \\
2 o més famílies & 9,3 & 0,6 \\
2 o més nuclis & 11,2 & 3,9 \\
\hline
\end{tabular}

Font: Elaboració pròpia a partir del Cens d'1 de novembre de 2001. Instituto Nacional de Estadística.

Entre els autòctons la residència s'organitzava a partir dels lligams familiars i molt especialment a partir de la família nuclear, per tant l'habitatge no es compartia amb altres persones no emparentades ni molt menys amb altres famílies, de manera que sols un 8,3\% dels habitants s'agrupen en llars al marge dels lligams familiars. Els nouvinguts també tenen a la família com a l'eix central que organitza la corresidència, però els problemes econòmics abans esmentats fan que la seva institució familiar estiga sotmesa a fortes pressions generades pel fet migratori.

Així, moltes famílies han d'acollir (de vegades sols rellogant algunes dependència de la casa) a altres persones externes; en altres ocasions la estratègia consisteix en que dues o tres famílies s'ajuntes baix un mateix sostre; molts pioners, únics membre aquí de la seva família, s'agrupen per compartir el pis; i quant el procés de reagrupament familiar encara és feble són poques les famílies les quals conviuen la família nuclear dels progenitors i algun fill en parella (sols el 2,9\% dels alloctons viuen en una llar que acull tres o més generacions, mentre que entre els autòctons en aquesta casuística hi són el 6,2\%). Per altra banda, determinats lligam propis de la família extensa es reforcen quant conviuen parents que no constitueixen una família nuclear.

SitUACIÓ ECONÒMICA I SOCIAL DE CASTELLÓ ALS ANYS NORANTA: FACTORS PULL

A la dècada dels noranta, tant a la província de Castelló com a Romania es van donar sendes conjuntures socioeconòmiques que, en certa manera, eren complementàries. 
Gràfic 8.10. Evolució de la taxa d'ocupació d'Espanya

i les tres províncies valencianes, 1977-2004

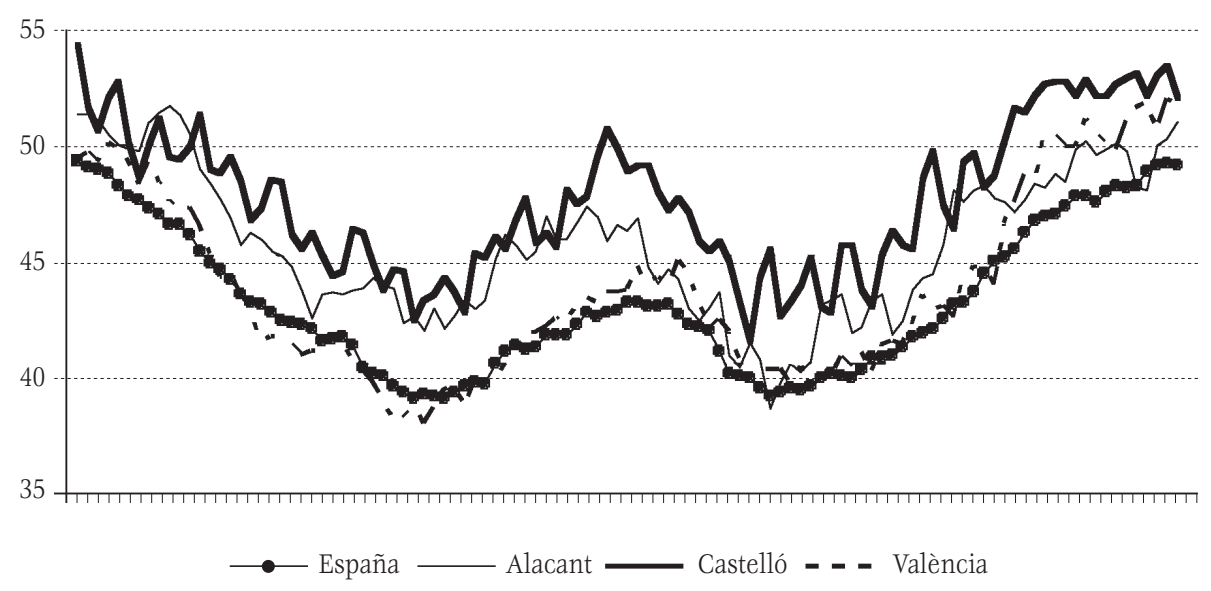

Font: Elaboració pròpia a partir de dades de la Encuesta de Población Activa. Instituto Nacional de Estadística.

Pel que a economia fa referència, Castelló es trobava en un procés accelerat de reindustrialitazació que la convertí en la província més industrial del País Valencià i en una de les més industrialitzades de l'estat. Aquest intens desenvolupament, basat fonamentalment en la indústria ceràmica, tigué com a conseqüència, a l'àmbit del mercat de treball, una expansió de la demanda de mà d'obra, la qual va situar les taxes d'ocupació provincials per damunt de les mitjanes estatal i de la resta del País Valencià i, al mateix temps, l'atur quedava en situació de plena ocupació tècnica (al voltant del 3\%).

Per altra banda, com que la situació concreta del mercat de treball no és únicament conseqüència de la conjuntura econòmica sinó també d'una determinada estructura demogràfica, Castelló presentava una població amb l'índex d'envelliment més elevat i les taxes de natalitat més baixes, des dels anys setanta, de totes les províncies valencianes, fets que, en combinació amb una taxa d'atur tradicionalment més baixa (el qual implica major taxa d'ocupació) i una participació femenina en el mon del treball relativament alta, aportaven una clara rigidesa al mercat de treball de part de l'oferta. A mes, l'estructura empresarial de Castelló presentava (i presenta encara) uns majors percentatges de petita i mitjana empresa, i més autònoms sense treballadors als seu càrrec, amb els problemes de rigide- 
sa per part de l'oferta que això comporta a l'hora de fer front a l'augment de la demanda, ocasionada pel desenvolupament econòmic que estava produint-se.

En aquest context es produeix l'arribada dels nous ciutadans a la província. El fenomen es va produir dintre d'unes coordenades internacionals i no tant sols la província va ser la receptora de fluxos sinó tots els països mediterranis, però, el fet que Castelló estiga situada entre les cinc primeres províncies en percentatge d'al-lòctons econòmics respecte a la població activa, du a pensar que molt poderosos factors pull (atracció) estaven actuant com a efecte crida per a unes poblacions que cercaven el millorament de les seves condicions de vida.

Per completar, com que hi ha un acord generalitzat que els moviments migratoris no s'expliquen tant sols per factors atracció-expulsió i que el paper reservat a les xarxes és fonamental, fins al punt que, una vegada iniciat el procés migratori, són aquestes i no les diferencials salarials o gap econòmic les que fan que el moviment sigui autosostingut $i$ els factors inicials perden rellevància (Portes, 1989), ${ }^{34}$ a principis dels anys noranta i de la mà de l'església adventista es va produir la primera onada immigratòria de romanesos a Castelló, la qual cosa va servir per engegar la construcció de la xarxa.

\section{SITUACIÓ ECONÒMICA I SOCIAL DE ROMANIA ALS ANYS NORANTA: FACTORS PUSH}

La desintegració a finals dels anys vuitanta del «bloc soviètic» va donar lloc a l'enfonsament del sistema econòmic i social, denominat «socialisme real», que es basava en la propietat estatal dels mitjans de producció. Com a conseqüència, Romania, els països de l'Est d'Europa i la mateixa Unió Soviètica, van entrar en una crisi generalitzada i al mateix temps en un període de transició cap a formes econòmiques capitalistes. Aquests països no tan sols havien d'inventar el capitalisme, sinó també desbastir tot el que des de la postguerra s'hi havia anat construint. Aquesta desintegració no sols va afectar l'Europa Oriental, sinó també, i de manera més profunda, les repúbliques del centre d'Àsia com ara Kazakhstan, Uzbekistan, Kirguizistan, Tadjikistan i Turkmenistan, l'enorme crisi de les quals estaria a la base de l'aparició en aquesta àrea (i també a les repúbliques caucàsiques)

34 Opus cit., p. 613. 
del terrorisme islamista, que per tant no tindria un origen religiós sinó econòmic (Napoleoni, 2004). Els efectes a l'Europa oriental (excepte el cas de l'antiga Iugoslàvia) van ser estructuralment semblants als d'aquestes repúbliques anomenades abans, però d'intensitat i conseqüències diferents. És dintre d'aquest marc econòmic i polític de referència en el que aquests països de l'Est europeu comencen a enviar quantitats significatives de població cap a l'Europa occidental i altres indrets del món.

Romania no en va ser una excepció, és més, va ser un dels països de l'antic bloc comunista més afectat per la crisi econòmica i social i, per tant, va passar a ser un dels grans emissors. Tota una sèrie de factors, no sols relacionats i resultants d'aquesta crisi, sinó també derivats de decisions polítiques preses per Ceaucescu, expliquen que el país es convertira en terra d'emigració.

Entre les causes de caràcter demogràfic, anteriors a la crisi de transició, cal ressaltar les polítiques natalistes que en 1966 el règim de Ceaucescu, com a mesura completament atípica a la regió (atès que altres països de l'àrea per contrarestar la radical davallada de la taxa de natalitat dels anys seixanta adoptaren mesures diferents), ${ }^{35}$ imposà al país, amb l'objectiu d'augmentar la població de 23 a 30 milions en deu anys. Els avortaments sols es van mantenir legals per a les dones embarassades de més de 45 anys que ja tenien fills i l'anticoncepció deixà d'estar a l'abast dels romanesos. L'efectivitat d'aquestes mesures no va ser igual en tots els àmbits geogràfics i medis socials del país, ja que les àrees rurals van ser més afectades que les urbanes i els grups socials desprotegits més que les capes mitjanes intelllectuals. Però, entre altres efectes, conduïren a una situació en la que el 86\% de totes les morts maternes a Romania eren el resultat directe d'avortaments il·legals. La prohibició de la interrupció voluntària de l'embaràs va ser completada per altres mesures, com ara la implantació d'impostos als adults sense fills, mesures afavoridores de l'allotjament per a dones amb tres o quatre fills i subvencions per el segon i tercer descendent. La conseqüència d'aquesta política pronatalista va ser un xoc amb efectes menors a llarg termini (Zamfir, 2003), però a curt va provocar un fort augment de la taxa de fertilitat entre 1966 (any de prohibició de l'avortament) i 1990 (any de la reinstauració), encara que la tendència històrica de disminució de famílies amb molts xiquets va continuar a ritme més moderat.

${ }^{35}$ Mesures de protecció i suport a les famílies amb fills (més cares i menys efectives). 
Quadre 8.12. Evolució de la taxa de fertilitat de Romania (naixements vius per 1.000 dones en edat fèrtil) entre 1966 i 1994

\begin{tabular}{lccc}
\hline ANYS & TAXA & ANYS & TAXA \\
\hline 1966 & 55,7 & 1975 & 77,5 \\
1967 & 105,5 & 1980 & 74,8 \\
1968 & 102,9 & 1985 & 64,2 \\
1969 & 89,1 & 1990 & 56,2 \\
1970 & 81,2 & 1994 & 43,3 \\
\hline
\end{tabular}

Font: Elaboració pròpia a partir de NSC (1995), Statistical Year Book, 1995. Bucharest: National Statistics Commission (dins Zamfir 2003).

Les conseqüències d'aquesta major fertilitat van ser ben diverses. Per una banda, va augmentar el nombre de xiquets no desitjats, es va deteriorar la salut perinatal i es va incrementar la mortalitat en el naixement (de 14,3\% en 1965 a 16\% en 1968). Però a llarg termini, el més significatiu va ser que totes aquestes cohorts del baby boom romanès començaren a inserir-se al mercat de treball a mitjans de la dècada dels vuitanta, fenomen que va continuar durant els anys noranta. La conjunció entre demografia i crisi econòmica, el desequilibri entre recursos i població, per dir-ho d'una altra manera, va entrar en un període molt conflictiu, que conduiria a una clara sobrepoblació, condició molt important per explicar els moviments migratoris que van començar en aquest moment. De fet, el que el país va guanyar des del punt de vista demogràfic en els anys de política natalista entre 1977 i 1992 (aproximadament un milió d'habitants), s'ha perdut entre 1992 i 2002. D'aquesta contracció, 330.000 es deuen a les pèrdues vegetatives i la resta als moviments migratoris (Vasile, 2004; Informe de la Comissió Europea, 2002). L'emigració, que va esclatar en 1990-1992, és, juntament amb la disminució de la taxa de natalitat i l'elevada taxa de mortalitat infantil, un dels trets més important de la demografia romanesa actual.

Centrant ara l'anàlisi de les causes d'emigració a l'àmbit econòmic, el primer que cal assenyalar és que durant la crisi i posterior període de transició es van produir tota una sèrie de canvis que han incidit en el desequilibri població-recursos, però de la part d'aquests últims: 1) va començar una forta ruralització, que ha comportat no tan sols l'augment de població a les zones rurals i un increment de pràctiques típiques de l'agricultura de subsistència, sinó també una inversió del procés d'urbanització que es donava des dels anys vuitanta (De Soto, 1997); 2) una clara disminució del producte interior brut a partir de 1990 (en 1995 el PIB era un 10,3\% inferior al de 
l'any 1990). ${ }^{36}$ La intensitat de la crisi, motivada per aquesta davallada del PIB, es va alleugerir, però no impedir del tot, pel ràpid creixement del sector informal de l'economia, fenomen no recollit oficialment per culpa del collapse del sistema estadístic estatal, però avaluat per fonts prestigioses amb taxes pròximes al 60\% (The World Bank, 2002); ${ }^{37}$ 3) durant la transició es va produir un gran canvi en la composició de l'output, que es concretà en una forta disminució de la proporció de béns de baixa qualitat, dels militars i dels béns de capital d'escassa productivitat. Aquest fenomen explicaria la caiguda de la participació del sector públic en el PIB romanès; que la pèrdua de llocs de treball s'ocasionara quasi exclusivament en les empreses estatals i, finalment, que la creació de nous llocs es concentrara en el sector privat, la participació del qual en l'output total no ha parat de créixer des de 1990; ${ }^{38}$ 4) les transformacions també es van produir a l'àmbit de la política monetària. Mentre va estar present la planificació centralitzada el tipus de canvi es va utilitzar com una eina política per desvincular els preus domèstics dels mundials, però quan va començar la transició al capitalisme produí una brusca contracció de les exportacions a causa de la sobrevaloració de les monedes, que va comportar necessàries i fortes devaluacions. S'intentava, d'una banda, evitar la crisi de la balança de pagaments estimulant l'activitat exportadora i, d'una altra, compensar la contracció de la demanda interna motivada per les mesures antiinflacionaries i per la ruptura dels mercats regionals que abans funcionaven. ${ }^{39}$ Així doncs, la moneda romanesa es va devaluar entre un 30 i un 35\% en el període 19932001 (Berg, 1999). Aquesta devaluació, juntament amb altres mesures d'estabilització macroeconòmica (dèficit fiscal, inflació), liberalització de preus i comerç, reformes fiscals i reestructuració de la despesa pública, a més

${ }^{36}$ Els problemes en aquest sentit començaren als anys 70 per influència de la crisi del petroli, moment en el qual la stagnation va aparèixer i acabà amb el ràpid desenvolupament industrial ocorregut entre 1950-1970 (període en el qual el socialisme suposà una millora real de les condicions de vida i benestar de la població) i, encara que el creixement continuà fins 1985 (Zamfir 2003, pp. 3-4), l'origen del collapse del sistema arranca d'aquests anys de la dècada dels 70 .

37 Aquesta davallada va ser generalitzada per a totes les economies en transició però a la CIS (Comunitat d'Estats Independents) i a les repúbliques de l'Àsia central encara va ser més aguda i més perllongada en el temps.

38 En aquesta data era del 17\%; en 1994 del 40\%; i en 1999 arribava al 60\%.

39 El 65\% de les exportacions es dirigien en els anys 1992-93 cap a la resta dels antics països socialistes, en canvi en els anys 1998-99 els països industrialitzats rebien el 71\% de les exportacions romaneses. 
de reformes legals, judicials i de les institucions públiques, era necessària per a posar en funcionament el sistema econòmic de mercat. Romania no va ser una alumna avantatjada a l'hora de posar en funcionament aquestes reformes i el retard és una de les causes per les quals el país no hi era entre les principals nacions receptores de capital estranger en el període 19921999 (The World Bank, 2000); 5) també és important ressaltar, dins de tot aquest procés de crisi i reestructuració econòmica de Romania, els canvis en la composició sectorial de l'output i les diferències que es van produir en aquest aspecte entre el període 1990-1991 i el de 1997-1998. En general, augmentà la terciarització en totes les economies en transició, a costa d'un sector industrial hiperdesenvolupat. Aquest sobredimensionament de la indústria estava provocat, d'una banda, pel fet que tant el comerç, com els serveis financers i els serveis en general estaven reprimits en les economies de planificació centralitzada, però, d'una altra, per que molta de la industrialització estava fonamentada en uns preus energètics per davall del nivell mundial, ${ }^{40}$ sense oblidar que la planificació també subsidiava el transport, impedia el contacte entre empreses, promocionava la concentració vertical i els monopolis i, com a conseqüència, moltes empreses en lloc de afegir output en restaven. La ineficiència econòmica provocada pel conjunt de factors adversos descrits és la causa, en primer 1loc, de la baixa productivitat de l'economia romanesa la qual, encara l'any 2002, era d'1,51 en paritat de poder adquisitiu per persona ocupada en la indústria i en els serveis, mentre que a l'Estat espanyol era de 14,22 i a la Unió Europea de 22,7. Altres estudis més recents la xifren en el 30,7\% de la mitjana de la UE (Galcoczi, 2004). A més, els costos laborals per hora treballada a Romania s'han quantificat en el 6,7\% de la mitjana de la Unió Europea (Luengo, 2003).41

Encara que les distàncies respecte a l'economia de l'Estat espanyol són menors que respecte als països més desenvolupats de la UE, les diferències són àmplies. Això implica dues coses: d'una banda, que són competidors nostres pel que fa a les deslocalitzacions industrials (que ja han començat a produir-se), i, d'altra banda, que el gap ${ }^{42}$ econòmic juntament les xarxes migratòries ja creades faran que els fluxos migratoris continuen, encara que l'economia romanesa mostre signes de recuperació.

40 A Rússia a l'abril de 1992 el preu del petroli domèstic era un 3\% del preu mundial.

41 A l'Estat espanyol són de 62,6. El país més pròxim de les economies en transició era Eslovènia, on representava el 40\% del cost mitjà de la Unió Europea.

${ }^{42}$ Lany 2002 a Romania la mitjana del salari brut mensual era de $493 €$ front als $1.980 €$ de la ue. 


\section{Característiques generals del mercat de treball a Romania}

La situació de crisi econòmica descrita tingué un impacte directe sobre el mercat de treball, que va sofrir importants transformacions. En primer 1loc, cal ressaltar que la taxa d'activitat romanesa mostrava una continua davallada des de 1996, any en què era del $72 \%$, per situar-se en el 68,5\% l'any 2001. Aquesta contracció de la població activa ha afectat tant els homes com les dones, però l'anàlisi per edats posa al descobert que la taxa ha disminuit sobretot en els grups d'edat més joves, concretament a la població entre 15 i 24 anys i a la compresa entre 35-44 (possiblement com a conseqüència directa de les emigracions, sempre selectives).

El segon aspecte que convé ressenyar és que les pèrdues de llocs de treball es van concentrat fonamentalment en el sector industrial, i es va passar de 4,7 milions d'ocupats en 1990 a 2,4 milions en 2000. De fet, entre l'any 1995 i el 2000 es van perdre actius en quasi totes les branques industrials excepte petroli, gas, transformació de cuir, indumentària, tints de pells i teixits. D'altra banda, en els serveis els únics subsectors creadors d'ocupació van ser el comerç al detall i a l'engròs (OECD, 2002) i en el sector primari, el procés de ruralització va fer créixer la població ocupada a l'agricultura (Dochia, 1999).

Hi havia, però, grans diferències pel que fa a la distribució de l'ocupació per sectors entre les àrees rurals i urbanes ja que, a les ciutats, el 47,8\% de la població activa treballava en el sector serveis i el 45,7\% en el secundari, mentre que a les zones rurals el 70\% ho feia en l'agricultura i tan sols el 14\% en els serveis.

Altre aspecte a destacar és l'enorme canvi produit en el mercat de treball atenent la distribució dels percentatges d'ocupats en els sector públic i privat, com a conseqüència del desmantellament de les empreses públiques, entre els anys 1994 i 2001, però sobretot a partir de 1996, els empleats estatals van disminuit un 56\%, mentre que els ocupats en el sector privat van augmentar, especialment en el sector primari. Alguns subsectors com el de la construcció, la metal-lúrgia, el químic i la mineria van continuar perdent llocs de treball.

També és remarcable l'augment de la flexibilitat en el mercat de treball, que a efectes pràctics ha implicat un increment de la inseguretat laboral i que es va traduir en: 1) majors percentatges (33,2\%) de contractes de menys de 40 hores (majoritàriament dones), de treballadors, sobretot homes, per compte propi, i de empresaris $(17,2 \%) ; 2$ ) el treball a temps 
Quadre 8.13. Evolució sectorial de l'ocupació a Romania, 1990-2000

\begin{tabular}{lccl}
\hline & 1990 & 1995 & 2000 \\
\hline Agricultura & 28 & 34 & 41,4 \\
Indústria & 44 & 34 & 27 \\
Serveis & 28 & 32 & 31,3 \\
\hline
\end{tabular}

Font: Elaboració pròpia a partir de NIS. Bucarest.

Gràfic 8.11. Canvis percentuals en la distribució de l'ocupació en els sectors públic i privat de Romania, 1994 i 2001

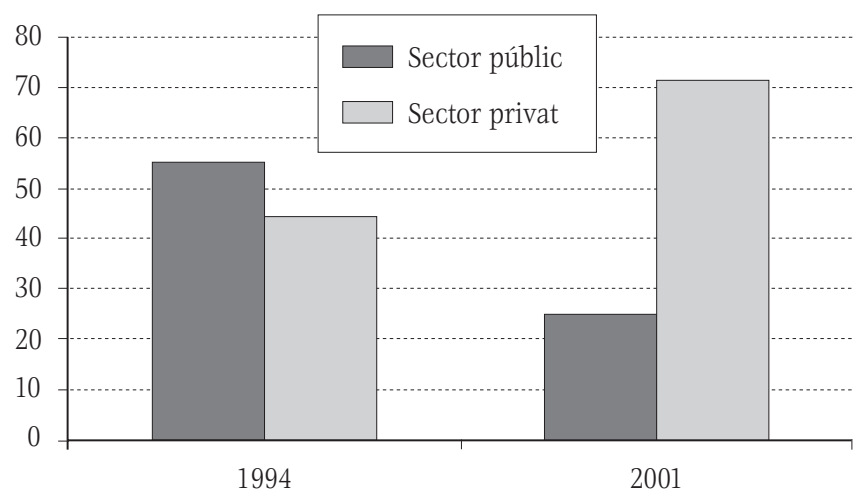

Font: Elaboració pròpia a partir de LFs (Labour Force Survey) d'Eurostat.

parcial ha augmentat lentament, però constantment, passant del 13\% l'any 1994 a més del 16\% l'any 2000, sense que açò puga ser com una mostra de maduresa de la força de treball romanesa (Mihaescu 2001); 3) a la segona meitat dels anys noranta la subocupació es va estendre de les persones que havien treballat a temps complet en les empreses sobrecarregades de personal i els treballadors de més de 50 anys, als joves de l'àmbit rural i treballadors a temps parcial que no cercaven una nova ocupació; 4) per finalitzar l'anàlisi del mercat de treball romanès s'ha de fer referència a la importància del sector informal. Segons l'Institut Nacional d'Estadística de Romania, l'economia submergida representava el 26,5\% del PIB l'any 2000, però altres fonts l'avaluaven al voltant del $50 \%$ del total del producte estatal i podria ocupar entre 2,4 i 3,1 milions de persones, ja que mentre que l'economia oficial es va contraure en termes reals al voltant d'un 3,6\% entre 1993 i 1998, l'economia soterrada va créixer un 400\%. La major part d'aquest increment estava relacionat amb la importació il-legal, que va tenir des de l'any 1993 un 640\% d'augment (Cercelescu, 1999). 
En aquesta conjuntura del mercat laboral els costos individuals que s'han d'avaluar a l'hora de prendre la decisió d'emigrar eren relativament reduïts i facilitava l'acceptació de les condicions del mon del treball als països d'acollida, també dominat per la precarietat, la desregularització i la flexibilització.

\section{La crisi social}

Limpacte de la reestructuració econòmica de Romania va comportar un enorme increment de l'índex de pobresa i un fort augment de les desigualtats socials des de finals dels anys 80. Encara que l'extrema pobresa és menor en les economies en transició que en altres països en desenvolupament, en 1998 el percentatge de població vivint amb menys d'un dòlar per dia era aproximadament tres vegades superior al de $1990 \mathrm{i}$ afectava un de cada 20 ciutadans en el conjunt de les economies en transició i d'una manera molt més accentuada a les repúbliques de l'Àsia Central. A Romania en concret, la distribució dels ingressos per càpita va passar de presentar un 0,23 en 1987 a 0,30 en 1998 en termes de coeficient de Gini. La conseqüència concreta fou que el percentatge de persones vivint en la pobresa extrema va augmentat des d'un 8\% en 1995 a un 16,6\% l'any 1999 i les persones en pobresa han passat del 25,3\% en 1995 al 44\% en 2000 (Stanculescu, 2003). El $61 \%$ pot ser considerat com pobresa temporal, és a dir, famílies pobres que reeixiran quan l'economia comence la seva expansió i vaja bé. De fet van eixir de la pobresa en 1996 (recuperació temporal de l'economia) i hi van recaure en 1997. La pobresa permanent afecta un 18\% de la població, la major part llauradors, ocupats per compte propi i empleats.

Amb aquesta situació socioeconòmica descrita, van començar a actuar clars factors d'expulsió i no és estrany en absolut que la població romanesa iniciara un procés d'emigració cercant una millora de les seves condicions de treball i per tant de vida. Les dades reals del volum total de l'emigració romanesa són difícils d'interpretar, atès que no hi són comptabilitzats els emigrants temporals que ixen i entren contínuament al país i que romanen en la illegalitat als països d'acollida. La tendència a treballar temporalment fora del país s'ha incrementat en els últims anys. En 1995 un terç dels joves de menys de 30 anys desitjaven treballar a l'estranger temporalment mentre que en 1999 aquest desig era compartit per un 50\% (Stanculescu, 2003: 209). El fenomen migratori ha estat present durant tota la 
transició però, almenys segons les dades oficials, ha anat perdent intensitat, la qual cosa ha de ser interpretada amb molta precaució. Es poden diferenciar dues etapes en tot el procés: la primera, de 1990 a 1993, es podria definir com un flux basat en raons ètniques i religioses que va afectar comunitats d'origen alemany (especialment de Transilvània), hongarès (6\% del total d'emigrants) i jueus ( $0,3 \%$ del total). Aquest seria el cas de l'efecte crida que determinades esglésies protestants van tenir, facilitant l'emigració de romanesos (Diminescu, 2003). ${ }^{43}$ Una segona onada va començar a partir de 1994, més intensa i més econòmica, amb disminució de l'emigració definitiva i augment d'un moviment circulatori continuat entre Romania i el país d'acollida, situació en la qual es troben una gran part dels romanesos castellonencs.

Altres característiques que s'han de ressaltar de l'emigració romanesa són: en primer lloc que la principal àrea emissora d'emigrants va ser Bucarest (17,3\% del total). ${ }^{44}$ Brasov, Timis, Cluj i Mures han aportat un $6 \%$ del total, respectivament, i finalment, unes altres localitats com ara Suceava, Sibiu i Bihor un 4\% cadascuna. Que no hi una correlació entre les zones d'origen i la taxa d'atur romanesa; (3) els principals llocs de destinació de la segona onada són els Estats Units, Itàlia, Alemanya i Canadà, amb aproximadament el 18\% del total d'emigrants cada un d'aquests. I que al voltant del 50\% són persones amb qualificació professional d'entre 26-40 anys, sent el segon grup per la seva importància numèrica es el comprés entre 18-25 anys, seguit del comprés entre 41-50 anys (Constantin, 2004).

43 No s'ha d'oblidar que els primers romanesos installats a Castelló estaven relacionats amb determinades esglésies protestants com ara els adventistes.

44 Jueus (37\%), romanesos (17\%) i alemanys (3\%). 


\section{9 .}

Recursos en internet sobre la inmigración en el Estado español*

Celestí Gimeno i Broch

JoAn SERAFÍ BERnAT I MARTí

* Este trabajo se ha beneficiado de las ayudas al proyecto UJI P1.IB2003-30. 


\section{INTRODUCCIÓN}

Este capítulo contiene una recopilación de páginas web que, en el ámbito del Estado español, tratan de los flujos migratorios desde diversos puntos de vista, con finalidades diversas y elaboradas por instituciones de diferentes tipos (públicas, privadas, etc.). En un estudio clásico tal vez hubiera sido el lugar apropiado para presentar un listado o una selección bibliográfica, pero una serie de motivos nos han aconsejado sustituir dicha relación por una panorámica sobre los recursos disponibles en la red.

Las razones que justifican esta decisión son de muy diversa índole, pero habría que resaltar, sin que el orden implique ningún tipo de jerarquía, las siguientes: 1) la globalidad o plurinacionalidad del tema implica que una recopilación bibliografía siempre hubiera sido incompleta, pues los estudios que sobre el mismo flujo se hayan podido hacer en cada uno de los países emisores aportando el otro punto de vista no siempre son fáciles de obtener y sin duda alguna, son del todo necesarios para la comprensión total del fenómeno migratorio; ${ }^{1}$ 2) por otra parte, el aspecto de aportación a la solidaridad y cooperación internacional que pretende este libro nos ha llevado a valorar que la puesta a disposición del amplio abanico potencial de interesados (estudiosos, propios alóctonos, asociaciones, ongs, público en general, etc.) de una recopilación de direcciones en internet relacionadas con el tema migratorio era la decisión más práctica, dinámica y accesible desde el punto de vista geográfico, sobre todo teniendo en cuenta que,

1 Aunque hay que reconocer que no se ha valorado suficientemente este aspecto en los estudios que se han hecho hasta el momento, al menos en nuestro país, convirtiéndose en una asignatura pendiente para los estudiosos del fenómeno. En este sentido habría que recordar que la compresión de un fenómeno y una problemática multilateral pasa siempre por el conocimiento de las razones de los otros y que una sociedad pluriétnica y pluricultural como la que está apareciendo necesita de la apertura e inclusión de las aportaciones de los demás. 
como se explicará después con mayor detalle, muchas de las direcciones son un puente para conseguir más información, entre ella, por supuesto, también bibliográfica; y 3) el papel cada vez más activo e importante que internet está asumiendo como instrumento de trabajo, no sólo en la elaboración científica sino en el intercambio de ideas e información entre las distintas áreas de este mundo global hace que ante los fenómenos que afectan a un número considerable de países, culturas, lenguas, etc. (como es el caso que no ocupa), instrumentos como internet adquieran mayor significación.

\section{OBJETIVOS DEL CAPÍTULO}

Así pues, el objetivo de este apartado del libro es poner a disposición de toda persona, grupo, institución o asociación, relacionada o interesada en las problemáticas y demás aspectos derivados de los flujos migratorios, un conjunto de recursos en la red, que en el ámbito del Estado español hacen referencia a la migración. Precisamente por el hecho de estar on line pueden ser consultadas desde todo el planeta por cualquiera agente interesado en conocer como se desarrolla este proceso multidimensional que es la inmigración en el Estado español y las diversas nacionalidades que lo integran.

\section{CONTENIDOS}

En esta línea que se acaba de exponer se han seleccionado una serie de páginas cuyo contenido, o parte del mismo, está relacionado de un modo u otro con los flujos migratorios: 1) un primer bloque de webs agrupa a centros de investigación, publicación y difusión de datos, la mayor parte de ellos relacionados o pertenecientes a las universidades españolas (públicas o privadas) que poseen departamentos, institutos, observatorios y/o grupos de investigación cuyo objeto de estudio son los flujos migratorios a escala estatal o autonómica; pero también las hay pertenecientes a organismos oficiales (ministerios, csic, etc.), y a entidades privadas que muestran el mismo interés (cajas de ahorro, colectivos de investigadores no relacionados directamente con el mundo universitario). El punto de enlace entre todos estos centros y organismos es el hecho de dedicarse al tema 
migratorio desde una perspectiva académica, poniendo a disposición de los estudiosos toda una serie de datos, fruto de investigaciones teóricas, además de una gran cantidad de recursos bibliográficos necesarios para el conocimiento del fenómeno en nuestro país. 2) Pero el tema migratorio dispone también de una faceta que va más allá de la mera erudición: su aspecto social. La instalación de los nuevos ciudadanos en las sociedades de acogida representa un reto mutuo del que se deriva una serie de consecuencias, algunas de ellas dramáticas, especialmente para el recién llegado, a pesar de la existencia de las redes de amparo entre los propios alóctonos. Estas problemáticas van desde la obtención de documentación adecuada (papeles, empadronamiento, permiso de trabajo, etc.), pasando por la integración (desintegración en muchos casos) en el mercado, obtención de una vivienda, acceso a los servicios sociales, aculturación/mantenimiento de la propia cultura, aprendizaje de la lengua/lenguas del país de acogida, inclusión de los hijos en el sistema educativo, etc. El desconocimiento de los mecanismos adecuados por parte de estos nuevos conciudadanos hace necesaria, o cuando menos conveniente, la existencia de toda una serie de organizaciones, gubernamentales o no-gubernamentales, especializadas en la información y/o soporte de esta población. Así pues, los apartados 2) y 3) ofrecen una relación de páginas encaminadas a estos cometidos anteriormente expuestos, recogiendo el primero de ellos a las organizaciones relacionadas con la administración pública y el segundo a las asociaciones privadas de carácter no-gubernamental.

\section{INFORMACIÓN QUE SE OFRECE}

Concretando más, el usuario de las páginas que se han seleccionado encontrará información variada sobre todo un conjunto de aspectos relacionados con el fenómeno migratorio: líneas de investigación sobre migraciones, interculturalidad, exclusión social y racismo, que son llevadas a cabo por investigadores de las principales universidades y centros de investigación en general a lo largo del territorio estatal; información sobre masters y estudios de postgrado en temas migratorios, así como cursos, jornadas educativas de potenciación de la interculturalidad; se proporciona acceso a centros de documentación, bibliotecas, bibliografía, hemerotecas, videotecas y archivos de prensa, que abarcan no sólo el tema migratorio sino problemáticas más específicas como la mediación intercultural; también 
se encontrarán trabajos y estudios, ponencias y documentos de trabajo sobre el impacto de inmigración en el mercado laboral; publicaciones, revistas, bancos de datos sobre investigadores y series estadísticas, que ofrecen una actualizada fotografía del movimiento especialmente a escala estatal, pero algunas también a escala internacional.

Otras páginas, con menor contenido académico pero no por ello menos importantes ni interesantes por su carácter social y asistencial, proporcionan acceso a la legislación de extranjería, tanto histórica como actual, y acuerdos bilaterales firmados por el Estado español y otros países; información sobre políticas sociales e integración, así como campañas de sensibilización; recursos materiales de todas las culturas, cursos y programas de adaptación lingüística dirigidos a la población alóctona, con el objeto de ayudar a su inclusión en nuestras sociedades. Los nuevos ciudadanos también encontrarán formularios de extranjería y modelos de impresos que pueden ser de gran ayuda a la hora de tramitar los papeles necesarios para su normalización como conciudadanos; incluso en algunas de las páginas se puede encontrar atención jurídica on line. Por último, en algunas de las webs se ofrecen servicios de interpretación y traducción.

\section{VALORACIÓN DE LA RED COMO INSTRUMENTO DE ESTUDIO} DEL FENÓMENO Y DE APOYO A LOS ALÓCTONOS

Los avances en las nuevas tecnologías han producido una división de opiniones entre los estudiosos e investigadores: unos, los entusiastas, ven a internet y otras tecnologías modernas con una fascinación ciega, y les conceden la capacidad de revolucionar el conocimiento y el intercambio de información; para otros, la utilidad de estos nuevos instrumentos tecnológicos está en cuestión. También hay quien opina que internet es un recurso de elite sin ninguna trascendencia social, especialmente para los países desarrollados. Pero, aunque todas estas opiniones tienen un cierto grado de verdad, la realidad es que, en el ámbito internacional, en los últimos diez años se ha desarrollado un nuevo concepto en el campo de la investigación, de la docencia y en la difusión de información. Los conocimientos trascienden las fronteras nacionales y disciplinarias e internet se está convirtiendo en el mayor instrumento de socialización y del intercambio de conocimiento, estando, como es normal, los países europeos y Estados Unidos a la vanguardia en este campo. 
Pero el mayor desafío arranca del peligro de que esta tecnología, base de la comunicación del futuro, quede en manos de una elite y no sea utilizada como instrumento del desarrollo socio-cultural de los pueblos y comunidades. A pesar de esta nube que enturbia el cielo, se puede decir que hoy cualquier ciudadano del mundo, teóricamente, puede acceder y ofrecer su propia información en la red las veinticuatro horas del día: libros, documentos, material de estudio, programas informáticos, información de todo tipo (cultural, comercial, política, noticias, ciencia, bases de datos), textos, sonido (música, voz), imagen (gráficas, fotografía, video), etc. También están en la red muchas organizaciones sociales, vecinales, cooperativas y sindicales; bibliotecas y museos; diarios y revistas; radio y televisión. Existen grupos de trabajo, de estudio, de intercambio científico, de conocimiento cultural, diálogos sobre los más variados temas, foros, conferencias y seminarios, entre personas situadas a miles de kilómetros de distancia. Se calcula que hay en el mundo cerca de 100 millones de personas que acceden a internet, consultando y aportando en esta gigantesca «biblioteca» mundial. Todo esto es un indicador claro de que con problemas o sin ellos se está desarrollando una verdadera revolución en el modo en que los humanos tratamos la información, el conocimiento y la comunicación. Las cosas, una vez consolidado el proceso y puesto a disposición de la mayoría, no volverán a ser como antes.

Esto, que ha sido expuesto en general, es, lógicamente, aplicable al fenómeno migratorio, que por su globalidad afecta a un número cada vez mayor de países y personas. Los flujos migratorios son radicalmente diferentes al resto de los movimientos globales (mercancías o capitales) que se están produciendo en nuestro planeta: son movimientos protagonizados por seres humanos y por tanto producen desarraigo intenso a corto y medio plazo, ruptura con las sociedades de origen y de los lazos familiares y al mismo tiempo marginación y aislamiento en las sociedades de acogida, además de choque cultural y nivel de vida cercano a la subsistencia para los actores que, por millones, participan en el fenómeno migratorio.

Es cierto que internet supone un riesgo si es utilizado como instrumento de incitación al odio racial o a la xenofobia, pero también es verdad que, inversamente, puede servir como herramienta de lucha contra el racismo, la discriminación y la intolerancia y, como no, (la recopilación que sigue es una prueba de ello) contribuir, de hecho ya lo hace, a la propagación y distribución de información positiva, de materiales, investigaciones y hechos sobre los nuevos ciudadanos y con ello pasa a ser un medio de acción contra 
el racismo y el antisemitismo, promoviendo la comprensión e incrementando la tolerancia. Y lo que es más importante, el movimiento es bidireccional: sirve tanto para los nuevos ciudadanos como para los viejos. La inclusión se ve por tanto facilitada, dado que aumenta el conocimiento mutuo.

Pero, aparte de lo anteriormente citado, conviene recalcar que internet ha inaugurado una nueva fase en los media y en las relaciones de "comunidad": tiene una doble dimensión: 1) medio de información y 2) medio de comunicación (Nedescu, 2003). En este sentido es un instrumento de importancia capital para seguir manteniendo los lazos con las comunidades de origen y suavizar el proceso de aculturación a que toda comunidad cultural fuera de su contexto está sometida, en nombre de la creación de sociedades multiculturales (que por cierto, nunca son igualitarias). La «proximidad electrónica» que las nuevas tecnologías proporcionan ayuda al mantenimiento de las identidades. Además, en los países más avanzados internet se está convirtiendo en un instrumento cada vez de mayor importancia en la búsqueda de empleo, no sólo para los autóctonos sino también para los nuevos ciudadanos. ${ }^{2}$ Evidentemente el uso y utilidad de la herramienta es directamente proporcional al nivel educativo del que disponen los nuevos ciudadanos y, por tanto, no es igual para todas las comunidades, ni por supuesto para todos los ámbitos culturales: ${ }^{3}$ a mayor dificultad de adquisición de las pautas lingüísticas de la sociedad de acogida, menor operatividad de la red como instrumento de inclusión, pero sobre todo depende de la existencia previa de redes de apoyo intracomunitarias: a mayor desarrollo de redes, menos importancia de la red en la búsqueda de trabajo.

Todo esto es lo que hace más interesante, por no decir necesario, disponer de información sobre los recursos que están en la red relacionados con todos estos problemas y que proporcionan herramientas de conocimiento y vías de solución de los mismos.

${ }^{2}$ Cuando este texto se encontraban en proceso de impresión, la Asociación de Trabajadores Autónomos ha creado una web (http://www.autonomosinmigrantes.com/index.htm) en la que se facilita toda la información necesaria para que quienes deseen convertirse en trabajadores autónomos en España puedan hacerlo desde sus países de origen.

${ }^{3}$ En este aspecto es muy interesante el resultado del trabajo de investigación «Media use among newly arrived immigrants to Australia» realizado por el Research Section of the Departament of Immigration and Multicultural Affairs del Gobierno australiano y publicado en abril de 2000 en el que se desprende una gran diferencia en el uso de la red según el origen de los colectivos y la existencia o no de redes de apoyo de los flujos (página 6). 


\section{WEBS SOBRE INMIGRACIÓN \\ I. Centros de investigación y difusión de información y estadísticas ${ }^{4}$}

\section{AGE. Asociación de Geógrafos Españoles}

INTERNET: http://www.ieg.csic.es/age/temas/inmigracion.htm RESUMEN DE SUS CONTENIDOS: En su página dedicada a la inmigración pueden encontrarse enlaces de interés, el texto de la ley de extranjería y materiales de trabajo que la UAB (Universidad Autónoma de Barcelona) tiene sobre la citada ley, diversos textos sobre racismo e inmigración, el informe del defensor del pueblo sobre la integración de los alumnos inmigrantes y artículos y publicaciones sobre el tema de los movimientos migratorios.

IDIOMA: Castellano.

CORREO ELECTRÓNICO: age@ieg.csic.es

Asociación para el Estudio de los Exilios y Migraciones Ibéricos Contemporáneos. UNED

INTERNET: http://www.aemic.org/

RESUMEN DE SUS CONTENIDOS: Homóloga de la francesa CERMI. Al principio se centraba en la emigración de España a Francia pero con el tiempo las miras se han ampliado a todas las migraciones de origen ibérico y con destino tanto a los distintos países de Europa como hacia Latinoamérica, África y Estados Unidos, con especial referencia a las migraciones políticas y a los países de acogida más significados. Dispone de archivos y documentos diversos (prensa, carteles, creación artística, correspondencia, testimonios orales, documentación filmada...) relacionados con el tema migratorio. Edita la revista «Migraciones y exilios» y los «Cuadernos de la AEMIC». IDIOMA: Castellano.

CORREO ELECTRÓNICO: secretariado@aemic.org

${ }^{4}$ Las fichas de las web de este apartado tienen todas como objetivo primario el de la investigación, lo cual ha llevado a simplificar su presentación obviando el apartado «objetivos» que presentan las fichas del apartado 6.2. 


\section{CED. Centre d'Estudis Demogràfics}

INTERNET: www.ced.uab.es

RESUMEN DE SUS CONTENIDOS: Centro de investigación de las estructuras y dinámicas poblacionales creado por la UAB y la Generalitat de Catalunya. Una de sus líneas de investigación es la inmigración. Dispone de un centro de documentación con hemeroteca, extensa bibliografía sobre población y un banco de datos con estadísticas demográficas de ámbito estatal y europeo. Sus links con los centros internacionales con los que comparte objetivos son fundamentales para cualquier investigador de la demografía.

IDIOMA: Catalán.

CORREO ELECTRÓNICO: demog@ced.uab.es

CEDIME. Centre d'Estudis d'Immigració i Minories Ètniques. Universitat Autònoma de Barcelona

INTERNET: http://selene.uab.es/cedime/

RESUMEN DE SUS CONTENIDOS: Adscrito al departamento de sociología, realiza investigación sobre migraciones interiores, flujos migratorios, racismo y xenofobia, situación laboral de los inmigrantes y políticas de integración. Actualmente trabaja sobre la inserción laboral de la inmigración extracomunitaria. Proporciona información y datos estadísticos sobre la inmigración, realiza análisis y dossiers de prensa y cursos de formación para técnicos biculturales, así como consultorías sobre políticas sociales y gestión de la diversidad. Trabaja también sobre legislación y proceso de regularización de los inmigrantes; condiciones de trabajo, racismo y discriminación en el entorno urbano; educación intercultural; género y emigrantes; multiculturalismo, lenguaje y discriminación. Permite el acceso a un listado de publicaciones realizadas por el grupo.

IDIOMA: Catalán, francés, inglés y castellano.

CORREO ELECTRÓNICO: cedimebcn@yahoo.es

\section{CEE. Centro de Estudios Europeos de la Universidad de Navarra} INTERNET: http://www.unav.es/cee/pagina_3.html

RESUMEN DE SUS CONTENIDOS: Sus líneas de investigación son: la etnicidad y el nacionalismo; la cultura, la identidad y la diferencia; las diferentes regiones culturales y regionalismos; comunicación intercultural y migración extra-europea. Proporciona información sobre publicaciones relacionadas con la inmigración y el interculturalismo. 
IDIOMA: Castellano.

CORREO ELECTRÓNICO: ebanus@unav.es

CEIM. Centro de Estudios para la Integración Social y la Formación de Inmigrantes. País Valencià

INTERNET: http://www.ceim.net/ceim.htm

RESUMEN DE SUS CONTENIDOS: Realización de estudios, informes, publicaciones, cursos, jornadas. También permite el acceso a programas de integración social, asistencia jurídica, y un aula de búsqueda de empleo interactiva. Su web también permite el acceso a la base de datos (Radiografía de las migraciones en el País Valencià) que el Ivie ha elaborado para el Observatorio de las Migraciones. La citada base esta compuesta de seis grandes áreas que tratan de los aspectos más significativos de la población alóctona, desde aspectos cuantitativos hasta los más sociales como acceso al trabajo y Seguridad Social, niveles de educación, acceso a la vivienda y condiciones de la misma.

IDIOMA: Castellano.

CORREO ELECTRÓNICO: ceim@ceim.net

CEPAM. Centro de Estudios de Economía, Población y Migraciones INTERNET: http://www.emigratio.com/

RESUMEN DE SUS CONTENIDOS: Sitio en la Red dirigido a la comunidad científica internacional que trabaja en el ámbito de los estudios migratorios y de la movilidad de la población. Proyecto vinculado académicamente a las universidades gallegas, ha creado y desarrollado un centro de documentación sobre las migraciones en Galicia. Publica la revista «MIGRATIO» (de población y migraciones) y dispone de un apartado sobre legislación, histórica y actual, de las migraciones.

IDIOMA: Gallego, castellano e inglés.

CORREO ELECTRÓNICO: cepam@cepam.org

CIDE. Centro de Investigación y Documentación Educativa. Ministerio de Educación y Ciencia

INTERNET: http://wwwn.mec.es/cide/jsp/plantilla.jsp?id = inv02d1a

RESUMEN DE SUS CONTENIDOS: Se puede acceder a un listado de las investigaciones realizadas por esta institución, la mayoría de las cuales está red. Destaca su colección de cuadernos de educación intercultural y listado bibliográfico de investigaciones de educación intercultural realizadas en España entre 1990 y 2002, así como enlaces. 
IDIOMA: Castellano.

CORREO ELECTRÓNICO: cide@educ.mec.es

СІDOB. Centro de Investigación, Docencia y Documentación de Relaciones Internacionales y Desarrollo

INTERNET: http://www.cidob.org/castellano/index.cfm

RESUMEN DE SUS CONTENIDOS: Dispone de biblioteca y centro de documentación. Muy interesante es su colección «Enciclopedia del Mediterráneo»: colección de libros de bolsillo que nace de un proyecto intercultural para dar a conocer el pasado y presente de los pueblos de la cuenca del mediterráneo. Publicada también en italiano, árabe, francés e inglés.

IDIOMA: Castellano, catalán e inglés.

CORREO ELECTRÓNICO: cidob@cidob.org

\section{CIP. Centro de Investigaciones por la Paz}

INTERNET: http://www.fuhem.es/portal/areas/paz/index.asp

RESUMEN DE SUS CONTENIDOS: Es un instituto de análisis sobre cuestiones internacionales que aborda, desde una perspectiva multidisciplinar, los conflictos armados, sus causas y actores, la prevención, los procesos de reconstrucción y resolución de conflictos. Además, estudia y divulga temas relacionados con la globalización, los Estados frágiles, el sistema multilateral, los derechos humanos, las migraciones, las identidades, los pueblos indígenas, el género, la justicia internacional, la educación para la paz y el desarrollo. El cip trabaja la cuestión de la identidad y los pueblos indígenas desde el reconocimiento de la diversidad cultural en el marco de los derechos y a favor del diálogo intercultural.

IDIOMA: Castellano.

CORREO ELECTRÓNICO: fuhem@fuhem.es

\section{CIPIE. Fundación Iberoamérica-Europa}

INTERNET: http://www.eurosur.org/CIPIE/

RESUMEN DE SUS CONTENIDOS: Centro de investigaciones, promoción y cooperación internacional. Recoge abundante información sobre migraciones, fundamentalmente el vaciado de prensa escrita de los principales periódicos españoles, organizado por temas.

IDIOMA: Castellano.

CORREO ELECTRÓNICO: cipie@nexo.es 
CIS. Centro de Investigaciones Sociológicas. Ministerio de la Presidencia INTERNET: http://www.cis.es/Page.aspx?OriginId = 69

RESUMEN DE SUS CONTENIDOS: Permite el acceso a ARCES (Archivo de Estudios Sociales) cuyo objetivo es recoger en un único punto la información y el acceso a datos sociales de distintos archivos del mundo. Está integrado no sólo por las encuestas elaboradas por el CIs, sino también por las de otras organizaciones tanto españolas como extranjeras. Este archivo ofrece, además, ficheros de micro datos para la investigación secundaria, procedentes de estudios por encuesta, junto con el conjunto de la información técnica necesaria para su utilización. En el apartado de publicaciones, además de otros temas, hay uno específico de la inmigración, donde aparecen toda una serie de trabajos relacionados con los flujos migratorios en el Estado español.

IDIOMA: Inglés y castellano.

CORREO ELECTRÓNICO: cis@cis.es

\section{Colectivo Ioé}

INTERNET: http://www.nodo50.org/ioe/

RESUMEN DE SUS CONTENIDOS: Información completa sobre las publicaciones (libros, artículos, colaboraciones en obras colectivas) de este grupo de investigación pionero en el estudio de los movimientos migratorios en nuestro país. Acceso a una biblioteca especializada en migraciones. Evolución de las migraciones en España: migraciones y trabajo, migraciones y género, comunidades y minorías étnicas y nacionales, actitudes hacia las poblaciones inmigrantes, integración de escolares de origen inmigrante en el sistema escolar español, etc.

IDIOMA: Castellano.

CORREO ELECTRÓNICO: ioe@nodo50.org

CREA. Amal: Inmigración y Mercado Laboral. Universitat de Barcelona INTERNET: http://www.pcb.ub.es/crea/amal/orientaciones.htm

RESUMEN DE SUS CONTENIDOS: AMAL: Inmigración y mercado laboral es un proyecto del plan I + D + I (Investigación, Desarrollo e Innovación) 2001/2005, del Ministerio de Ciencia y Tecnología, de la Secretaría de Estado de Política Científica y Tecnológica. Pretende definir una serie de estrategias sociales y de formación que contribuyan a la superación de la exclusión en el ámbito laboral del colectivo inmigrante, en especial sobre la comunidad árabe y musulmana. Posee una sección de presentación de 
trabajos y estudios sobre el impacto de la inmigración en el mercado laboral, en la estructura social y en la educación, así como interesantes links de legislación, asociaciones de acogida, empresas de trabajo temporal. IDIOMA: Castellano.

CORREO ELECTRÓNICO: crea@pcb.ub.es

\section{Departamento de Antropología Social. Facultad de Geografía e Historia} de la Universidad de Sevilla

INTERNET: http://82.194.66.80/ yloenvia/usuarios/fgh/03_inve/03_01_proy/ 03_01_01.html

RESUMEN DE SUS CONTENIDOS: Investigación sobre relaciones interétnicas, procesos de integración y migraciones desde el norte de África. Legislación y proceso de regularización de los inmigrantes; condiciones de trabajo, racismo y discriminación en el entorno urbano; educación intercultural; género y emigrantes; multiculturalismo, lenguaje y discriminación; etc. IDIOMA: Castellano.

CORREO ELECTRÓNICO: fgh@usrec.us.es

\section{ECONET. Centro Regional de Estadística de Murcia}

INTERNET: http://www.carm.es/econet/

RESUMEN DE SUS CONTENidos: Proporciona datos concretos de la Región de Murcia: evolución de saldos migratorios (emigración-inmigración), migraciones interiores, inmigración procedente del extranjero, etc. En series completas de entre los años 1994 y 2003, con especial desagregación de resultados entre los años 1998 y 2003. Todos estos datos pueden también ser consultados en ámbito municipal. En su apartado de publicaciones permite el acceso a los padrones municipales, al Censo y a los datos sobre movimientos migratorios en Murcia en formatos pdf y en cd. Hay un buzón de sugerencias y de petición de datos.

IDIOMA: Castellano.

CORREO ELECTRÓNICO: Tiene acceso pero no explicita su dirección.

\section{EUSTAT. Euskal Estatistika Erakundea}

INTERNET: http://www.eustat.es/

RESUMEN DE SUS CONTENIDOS: Proporciona datos sobre población alóctona por territorio histórico, comarcas de residencia, continente de nacionalidad y sexo para el año 2001. En diferente apartado se pueden encontrar datos de la población alòctona de 16 años y más en relación con la 
actividad y continente de origen para el mismo año 2001. Su banco de datos permite la opción de poder elaborar tablas a la carta según las necesidades concretas de la consulta. Dispone de un servicio de información para atender solicitudes de información estadística con servicio de peticiones a medida, tanto para particulares y empresas como para organismos de todo tipo. Es posible la consulta on line del catálogo de la biblioteca del instituto.

IDIOMA: Eusquera, inglés y castellano.

CORREO ELECTRÓNICO: webmaster@eustat.es/biblioteca@eustat.es

\section{FUHEM. Fundación Hogar del Empleado}

INTERNET: http://www.fuhem.es/portal/areas/centro_documentacion/ index.asp

RESUMEN DE SUS CONTENIDOS: FUHEM cuenta con un centro de recursos especializado en conflictos, derechos humanos, desarrollo, educación para la paz y el desarrollo, medio ambiente, migraciones, género, relaciones internacionales y paz. Consta de cuatro fondos diferentes: un archivo de prensa, que incluye periódicos nacionales e internacionales; un centro de documentos; un tercero de revistas, con alrededor de 150 títulos activos y un archivo histórico de 120 títulos; una biblioteca con más de 5.000 volúmenes.

IDIOMA: Castellano.

CORREO ELECTRÓNICO: fuhem@fuhem.es

GECIM: Grup d'Estudis sobre Ciutadania, Immigració i Minories de la Universitat de València

INTERNET: http://www.uv.es/immigracio/v/info/index.htm

RESUMEN DE SUS CONTENIDOS: Lleva a cabo actividades de investigación, divulgación, publicación y asesoramiento en derechos humanos e inmigración. Presenta información sobre los proyectos de investigación en marcha que tiene el grupo.

IDIOMA: Catalán e inglés.

CORREO ELECTRÓNICO: e.mail@uv.es

\section{GES. Gabinet d'Estudis Socials}

INTERNET: http://www.gabinet.com/

RESUMEN DE SUS CONTENIDOS: El GES ha ido reuniendo un gran número de materiales en los ámbitos temáticos que lo caracterizan: cooperativismo, 
mercado de trabajo, inmigración, juventud, inserción, política social, pobreza y exclusión, etc. En conjunto son unas 9.000 referencias a las cuales cabe añadir aún la informatización de las principales noticias aparecidas en los medios de comunicación sobre las citadas temáticas y las cerca de 300 investigaciones propias del GES.

IDIOMA: Castellano.

CORREO ELECTRÓNICO: ges@gabinet.com

GRIIP. Grup de Recerca en Immigració i Innovació Política. Universitat Pompeu Fabra

INTERNET: http://www.upf.edu/dcpis/griip/

RESUMEN DE SUS CONTENIDOS: El GRIP es un grupo de investigadores interesados en los procesos de transformación social y política que tienen su origen en la inmigración. Sus líneas de análisis e investigación giran alrededor de las políticas de inmigración, la ciudadanía, la nacionalidad y la discriminación. Dispone de un banco de publicaciones, ponencias en congresos y simposios, así como de documentos de trabajo.

IDIOMA: Catalán.

CORREO ELECTRÓNICO: griip@upf.edu

GRM. Grup de Recerca sobre Migracions. Universitat Autònoma de Barcelona

INTERNET: http://seneca.uab.es/migracions/

RESUMEN DE SUS CONTENIDOS: Localizado en el Departamento de Geografía de la citada universidad, el GRM investiga en el área de la inmigración desde el punto de vista interdisciplinario, con especial referencia a los países del sur de Europa. También se dedica a la docencia en temas relacionados con las migraciones. Dispone de una importante base de datos sobre bibliografía de las migraciones a Catalunya.

IDIOMA: Catalán.

CORREO ELECTRÓNICO: gr.recerca.migracions@uab.es

Grup de Recerca del Gènere, la Interculturalitat i els Estudis Culturals Mediterranis. Universitat Rovira i Virgili

INTERNET: http://www.urv.es/centres/Grups/grg/

RESUMEN DE SUS CONTENIDOS: Dedicado a reforzar la interdisciplinariedad y los contactos internacionales entre las sociedades mediterráneas, resal- 
tando la interdependencia y los lazos culturales comunes de toda el área. Organizador del master en estudis culturals mediterranis i del curso de doctorado Estudis Culturals Mediterranis (DEA). Especializado en los movimientos migratorios del área mediterránea.

IDIOMA: Catalán e inglés.

CORREO ELECTRÓNICO: capsfll@fll.urv.es

\section{Grupo de Investigación Xbilia. Universidad de Sevilla}

INTERNET: http://sapiens.ya.com/grupoixbilia/

RESUMEN DE SUS CONTENIDOS: Realiza actividades de investigación sobre temas de inmigración entre el norte de África y el Estado español, relaciones euro-magrebís, sobre comunidades árabo-musulmanas en el mundo occidental y de historia del mundo árabe. Publica la colección de estudios Alfar-Xbilia.

IDIOMA: Castellano.

CORREO ELECTRÓNICO: rvalencia@us.es

HEGOA. Instituto de Estudios sobre Desarrollo y Cooperación Internacional. Universidad del País Vasco

INTERNET: http://www.hegoa.ehu.es/topics/documentacion/

RESUMEN DE SUS CONTENIDOS: El centro de documentación de Hegoa tiene como misión promover la formación, investigación e información sobre Desarrollo y Cooperación Internacional, con el objetivo de contribuir a un cambio de valores y una comprensión crítica, solidaria y global de los problemas de nuestro mundo. Cuenta con más de 14.000 referencias de libros, documentos, anuarios y artículos de revistas especializadas disponibles en internet. Publica la Revista «RPN» (Red de Comunicación sobre Refugiados) y la revista «Migraciones Forzosas».

IDIOMA: Eusquera y castellano.

CORREO ELECTRÓNICO: hegoa@bs.ehu.es/hegoa@vc.ehu.es

\section{IAE. Instituto Aragonés de Estadística}

INTERNET: http://portal.aragob.es/

RESUMEN DE SUS CONTENIDOS: Dispone de datos concretos de población alóctona residente en Aragón: proceso de regularización (también por CCAA), afiliación de alóctonos a la Seguridad Social, población total con permiso de residencia y número de empadronados en la comunidad. También proporciona información sobre el «Plan Integral para la inmigración en 
Aragón», para el que se solicitan sugerencias, y da acceso a los demás planes que puedan existir en el ámbito estatal. Dispone de una guía de recursos de la inmigración en cada una de las tres provincias de la Comunidad y acceso a publicaciones, enlaces de interés y legislación de extranjería de ámbito autonómico, estatal e internacional.

IDIOMA: Castellano.

CORREO ELECTRÓNICO: portal@aragon.es

\section{IBAE. Institut Balear d'Estadística}

INTERNET: http://www.caib.es/ibae/demogra.htm

RESUMEN DE SUS CONTENIDOS: En su apartado de demografía proporciona datos concretos sobre migraciones relativos a las Illes Balears. Da acceso a monografías y estudios sobre la inmigración en su ámbito de referencia.

IDIOMA: Catalán y castellano.

CORREO ELECTRÓNICO: ibae@caib.es

\section{ICE. Institut Català d'Estadística}

INTERNET: http://www.idescat.es

RESUMEN DE SUS CONTENIDOS: Pone a disposición del visitante una completísima cantidad de datos sobre migraciones internas y externas en Catalunya actualizadas anualmente.

IDIOMA: Castellano, inglés y catalán.

CORREO ELECTRÓNICO: indescat@indescat.es

IEG. Instituto de Economía y Geografía. Consejo Superior de Investigaciones Científicas (CSIC)

INTERNET: http://www.ieg.csic.es/demografia/contacto.html

RESUMEN DE SUS CONTENIDOS: Desarrollo de investigaciones sobre las inmigraciones nacionales e internacionales. Dispone de una biblioteca con fondos de geografía, economía y demografía.

IDIOMA: Castellano e inglés.

CORREO ELECTRÓNICO: demografia@ieg.csic.es

IEPALA. Instituto de Estudios Políticos para América Latina y África INTERNET: http://www.iepala.es/objetivos.htm

RESUMEN DE SUS CONTENIDOS: Están relacionados con la investigación, análisis y estudio de las realidades del Tercer Mundo y de las relaciones 
Norte/Sur, el fomento de la conciencia individual y colectiva en favor de los derechos de los pueblos y de los individuos. Formación de personas y grupos, conocimiento y conciencia, la acción y servicio solidarios a los pueblos del Tercer Mundo. Se ocupa en crear medios e instrumentos de documentación, información y comunicación que sirvan a los hombres y pueblos del Tercer Mundo, así como en activar y formar la conciencia crítica de los grupos y sectores sociales más responsables del Norte, para que se impliquen en el cambio de estructuras y relaciones con el Sur. Dispone de un amplio temario sobre problemas relacionados con el Tercer Mundo, sus economías, educación, etc.

IDIOMA: Castellano.

CORREO ELECTRÓNICO: iepala@eurosur.org

\section{IGE. Instituto Galego de Estatística}

INTERNET: http://www.ige.xunta.es/

RESUMEN DE SUS CONTENIDOS: En su apartado de población hace referencia a los movimientos migratorios. Dispone de la serie completa de los mismos entre 1990 i 2003 y da información de los saldos migratorios, emigraciones e inmigraciones según lugar de destino y origen, así como, en resultados detallados, de las características de dichos movimientos por sexo, edad, nacionalidad, etc. Pone a disposición del visitante un catálogo de publicaciones y una biblioteca informatizada donde pueden encontrarse todas las publicaciones referentes al tema que nos ocupa para el ámbito gallego.

IDIOMA: Gallego, inglés y castellano.

CORREO ELECTRÓNICO: ige@xunta.es

\section{INE. Instituto Nacional de Estadística}

INTERNET: http://www.ine.es/

RESUMEN DE SUS CONTENIDOS: Aparte de los censos de población, padrones municipales y estudios estadísticos de todo tipo, dispone, dentro de su sección de Demografía y Población, de un apartado específico de migraciones en el que pueden consultarse directamente la Estadística de Variaciones Residenciales, la Encuesta de Migraciones y las Estadísticas de la migración asistida.

IDIOMA: Castellano e inglés.

CORREO ELECTRÓNICO: indice@ine.es/biblioteca@ine.es 


\section{Institut Europeu de la Mediterrània}

INTERNET: http://www.iemed.org/

RESUMEN DE SUS CONTENIDOS: Consorcio participado por la Generalitat de Catalunya, el Ministerio de Asuntos Exteriores y Cooperación y el Ayuntament de Barcelona. Heredero del legado del Institut Català de la Mediterrània, impulsa actividades de investigación, debate, difusión de temas y problemáticas relacionadas con la economía, sociedad, política y cultura. En su área dedicada a las migraciones actúa a modo de observatorio de las migraciones mediterráneas a la luz de la experiencia adquirida como centro de estudio de los movimientos humanos y de la interculturalidad. Dispone de importantes links sobre migraciones internacionales, legislación de extranjería, políticas de inmigración, revistas.

IDIOMA: Catalán, español, francés e inglés.

CORREO ELECTRÓNICO: info@iemed.org

\section{Instituto de Estadística de la Comunidad de Madrid}

INTERNET: http://www8.madrid.org/iestadis/fijas/estructu/demograficas/ migra/imigracd.htm

RESUMEN DE SUS CONTENIDOS: Presenta las estadísticas del movimiento migratorio de la Comunidad de Madrid desde el año 1988 hasta el 2003. Permite el acceso al Anuario en el que se encuentran datos sobre emigración asistida por lugar y tiempo de emigración y demandas de empleo en el extranjero; sobre inmigrantes españoles por países de procedencia; extranjeros residentes por país de nacionalidad; extranjeros repatriados, inmigración y emigración interiores; componentes del saldo migratorio en la Comunidad de Madrid por municipios y por zonas estadísticas según sexo e inmigrantes extranjeros por país de procedencia.

IDIOMA: Castellano.

CORREO ELECTRÓNICO: iestadis@madrid.org

\section{Instituto de Estudios Cajamar}

INTERNET: http://www.instituto.cajamar.es/mediterraneo/indice1.htm RESUMEN DE SUS CONTENIDOS: Instituto dedicado al estudio y la publicación de trabajos relativos a diversos apartados como procesos migratorios, agricultura, ciudades y arquitectura, medio ambiente, turismo. En su sección dedicada a la inmigración permite la descarga de toda una serie de trabajos de primer nivel dedicados a los flujos migratorios y su problemática. 
IDIOMA: Castellano.

CORREO ELECTRÓNICO: cajamar@cajamar.es

\section{Instituto Universitario de Estudios sobre las Migraciones. Universidad Pontificia Comillas}

INTERNET: http://www3.upco.es/pagnew/iem/

RESUMEN DE SUS CONTENIDOS: Sus objetivos fundamentales son el seguimiento de los procesos migratorios que afectan a España, el estudio de la problemática derivada de la identidad social e identidad nacional de los inmigrantes, de los procesos de integración de los inmigrantes en la sociedad española y su estatuto jurídico, así como de las políticas sociales e integración. Dispone de una prestigiosa «Revista de migraciones», un fondo documental y un directorio abierto de investigadores, todos consultables a través de la web.

IDIOMA: Castellano.

CORREO ELECTRÓNICO: info.migraciones@iem.upco.es

\section{ISTAC. Instituto Canario de Estadística}

INTERNET: http://www.gobiernodecanarias.org/istac/

RESUMEN DE SUS CONTENIDOS: Proporciona datos específicos de población extranjera en la Islas, así como de las características de los asentamientos de población extranjera por municipios en Canarias en la década de los 80. IDIOMA: Castellano.

CORREO ELECTRÓNICO: istac@gobiernodecanarias.org

\section{IVE. Institut Valencià d'Estadística}

INTERNET: http://ive.infocentre.gva.es/

RESUMEN DE SUS CONTENIDOS: Proporciona información concreta sobre inmigración (absoluta, tasas, procedencia, residencia, etc.) y de conceptos utilizados en la elaboración de los datos. También da acceso a un fondo documental especializado en información estadística sobre el País Valencià de los organismos estadísticos oficiales de las Comunidades Autónomas, del Instituto Nacional de Estadística, la Administración General del Estado y la Oficina de Estadística de la Unión Europea (EUROSTAT), existiendo además, a disposición del visitante, un formulario electrónico de petición de datos.

IDIOMA: Catalán y castellano.

CORREO ELECTRÓNICO: difusion_ive@gva.es 


\section{Laboratorio de Estudios Interculturales de la Universidad de Granada} INTERNET: http://www.ugr.es/ 1dei/

RESUMEN DE SUS CONTENIDOS: LdEI es un grupo de investigación reconocido por el Plan Andaluz de Investigación. Su actividad fundamental es el estudio, la investigación y la docencia, desde diversas perspectivas disciplinares (antropología, pedagogía, psicología, sociología, etc.), de los diversos temas relacionados con la interculturalidad: migraciones, racismo, xenofobia, conflicto étnico y nacionalismo. Dispone de un Centro de Documentación en Interculturalidad (CdDI), ubicado en el Edificio Aulario de la Facultad de Ciencias de la Educación de la Universidad de Granada, que cuenta con uno de los fondos documentales más importantes del Estado español sobre migraciones, exclusión social y cultural, racismo, xenofobia, minorías étnicas, interculturalidad, etc., así como de una hemeroteca, un observatorio de medios de la inmigración y una interesante página de enlaces sobre temas de inmigración.

IDIOMA: Castellano.

CORREO ELECTRÓNICO: lidei@platon.ugr.es

MIGRACOM. Observatori i Grup de Recerca sobre Migració i Comunicació. Universitat Autònoma de Barcelona

INTERNET: http://www.migracom.org/

RESUMEN DE SUS CONTENIDOS: Es un grupo de investigación que ha estudiado el tratamiento de los inmigrantes no-comunitarios en los medios de comunicación catalanes y españoles y la imagen que de ellos proyectan los citados media. Ha redactado un «Manual d'estil sobre Minories ètniques del Collegi de Periodistes de Catalunya» en el que se proponen protocolos de lenguaje y enfoque del tema migratorio para los profesionales del periodismo.

IDIOMA: Catalán y castellano.

CORREO ELECTRÓNICO: migracom@migracom.org

\section{Observatorio de la Inmigración de Tenerife}

INTERNET: http://obiten.net/

RESUMEN DE SUS CONTENIDOS: Iniciativa conjunta del Cabildo de Tenerife y la Universidad de La Laguna para el estudio del fenómeno inmigratorio, además de ser centro de recopilación y validación de información. Dispone de un banco de datos sobre investigadores canarios del tema de la inmigración y de investigaciones financiadas por el organismo en el ámbi- 
to de la isla de Tenerife. También puede consultarse una hemeroteca, con un resumen de noticias sobre inmigración en las Islas Canarias.

IDIOMA: Castellano.

CORREO ELECTRÓNICO: alexis@obiten.net

\section{OIT. Organización Internacional del Trabajo}

INTERNET: http://www.ilo.org/public/spanish/protection/migrant/ilmdb/ framemain.htm

RESUMEN DE SUS CONTENIDOS: Base de datos de las migraciones laborales internacionales. Permite el acceso a los datos del conjunto de países y también las comparaciones entre ellos. Dispone del «Rincón del visitante», donde existe la posibilidad de contribuir a la base de datos ILM, depositar las aportaciones estadísticas potenciales y formular preguntas. Muy interesantes son los links internacionales que pueden ser encontrados en esta página.

IDIOMA: Castellano, inglés y francés.

CORREO ELECTRÓNICO: migilm@ilo.org

TEIM. Taller de Estudios Internacionales Mediterráneos. Universidad Autónoma de Madrid

INTERNET: http://www.uam.es/otroscentros/TEIM/

RESUMEN DE SUS CONTENIDOS: Desde distintas disciplinas (Sociología del Mundo Árabe, Arabismo y Filología, Antropología, Psicología Social, Historia, Economía), ha desarrollado actividades relacionadas con las Ciencias Sociales y el mundo magrebí, organizando o participando en coloquios y congresos, impartiendo conferencias y publicando trabajos relacionados con las realidades sociales y políticas del Magreb, del Mundo Árabe y de las migraciones árabes hacia Europa. El TEIM plantea sus actividades como una unidad de investigación dedicada preferentemente al análisis del mundo mediterráneo desde una perspectiva académica interdisciplinar que abarca un doble enfoque: 1) temático (esfera cultural, social, política, económica y de seguridad) y 2) geográfico (Magreb, Oriente Medio, países del sur de la ue y Mediterráneo). Desarrolla al mismo tiempo un Doctorado de Estudios Internacionales Mediterráneos en el marco del Departamento de Estudios Árabes e Islámicos de la Universidad Autónoma de Madrid.

IDIOMA: Castellano.

CORREO ELECTRÓNICO: teim.uam@uam.es 


\section{Instituciones públicas y administraciones}

APOI. Dirección General de Inmigración, Cooperación al Desarrollo y Voluntariado. Consejería de Familia y Asuntos Sociales. Comunidad de Madrid

INTERNET: http://www.madrid.org/cservicios_sociales/dg_inmigracion/ index.htm

oBJETIVos: Inserción social de las minorías procedentes de los países del este de Europa.

RESUMEN DE SUS CONTENIDOS: Atención integral a las personas acogidas a través de las siguientes áreas de intervención: área de información, orientación y valoración social, de mediación y seguimiento familiar, de orientación y seguimiento sanitario, de promoción de adultos, infantil (de $0 \mathrm{a}$ 4 años), de menores (seguimiento y apoyo extraescolar) y área de orientación laboral y búsqueda activa de empleo.

IDIOMA: Castellano.

CORREO ELECTRÓNICO: oficina.atencion.ciudadano@madrid.org

\section{Aula de Extranjería del Ilustre Colegio de Abogados de Madrid}

INTERNET: http://www.icam.es/grupostrabajo/canales/noticias.jsp?canal = ex oBJETIVOS: Los propios de un colegio profesional.

RESUMEN DE SUS CONTENIDOS: Noticias sobre temas de inmigración, legislación relacionada con los nuevos ciudadanos, modelos de formularios de extranjería, etc.

IDIOMA: Castellano.

CORREO ELECTRÓNICO: icam@icam.es

\section{Aula Intercultural. FETE-UGT}

INTERNET: http://www.aulaintercultural.org/

OBJETIVOs: Educar en el respeto y la convivencia entre las distintas culturas. 
RESUMEN DE SUS CONTENIDOS: Posee interesantes recursos contra el racismo y la xenofobia, así como recursos musicales de todas las culturas. Pone a disposición de los educadores juegos antirracistas y un taller de cuentos dirigido al desarrollo del respeto intercultural.

IDIOMA: Castellano, catalán, gallego, eusquera, inglés y francés.

CORREO ELECTRÓNICO: info@aulaintercultural.org

\section{CCOO. Migraciones}

INTERNET: http://www.ccoo.es/sindicato/migraciones.html

OBJETIVOS: Los propios de una organización sindical.

RESUMEN DE SUS CONTENIDOS: Ofrece información sobre toda clase de servicios al inmigrante, como asistencia jurídica o asesorías para trabajadores autónomos, vivienda, seguros, formación profesional y sindical, descuentos en agencias de viajes y hoteles, turismo, etc., así como publicaciones (tanto periódicas como monográficas), legislación sobre temas relativos al contrato de trabajo y mundo laboral en general, y todos los aspectos relativos a la extranjería.

IDIOMA: Castellano.

CORREO ELECTRÓNICO: cCOO@cCOO.es

Centro de Información Administrativa. Ministerio de Administraciones Públicas

INTERNET: http://www.igsap.map.es/cia.htm

oBJETIVOs: Información y soporte al ciudadano en sus relaciones con la administración publica.

RESUMEN DE SUS CONTENIDOS: Servicio de atención al ciudadano en temas de empleo público, procedimientos administrativos, formularios en línea, legislación, subvenciones, becas y ayudas. Proporciona acceso al BOE y demás diarios oficiales, así como a un directorio de páginas web de la administración central, autonómica, de las diputaciones y entes locales. A través de un localizador permite conocer las direcciones de las oficinas de información y registro de la administración en todo el territorio estatal. También dispone de buzones en los que solicitar cualquier tipo de información sobre los servicios generales de administración del estado y remitir correos electrónicos de quejas y sugerencias.

IDIOMA: Castellano.

CORREO ELECTRÓNICO: portal.general@map.es 


\section{CITE. Centre de Informació per a Treballadors Estrangers. CCOO}

INTERNET: http://www.conc.es/cite/

OBJETIVOS: Asesorar y orientar sobre la ley de extranjería, tramitar permisos de trabajo, residencia y reagrupación familiar. Organización de cursos de catalán, de mediación y comunicación en los centros de enseñanza en diferentes lenguas. Potencia campañas de sensibilización contra el racismo e integración social.

RESUMEN DE SUS CONTENIDOS: Apartado de documentación y noticias sobre temas migratorios.

ÁMBITO DE ACTUACIÓN O DE IMPLANTACIÓN: Catalunya.

IDIOMA: Catalán, castellano, inglés, francés, tagalo, rumano, chino, árabe y ruso.

CORREO ELECTRÓNICO: immigracio@Conc.es

CNICE. Centro Nacional de Información y Comunicación Educativa. Ministerio de Educación y Ciencia

INTERNET: http://www.cnice.mecd.es/recursos2/atencion_diversidad/ index.html.

OBJETIVOS: En su apartado de interculturalidad pretende acercar al mundo educativo, profesores, padres, alumnos y todo aquel interesado en la materia, el estado de la cuestión en todo lo relacionado con la interculturalidad y cómo se está actuando desde las distintas instancias educativas y escolares.

RESUMEN DE SUS CONTENIDOS: Estas páginas recogen experiencias, información, recursos, legislación educativa y todos aquellos aspectos educativos relacionados con la atención a la diversidad. En la sección dedicada a la inmigración proporciona información útil sobre las leyes de extranjería, programas de adaptación lingüística, actuación educativa de las diferentes CCAA. Dispone también de información sobre minorías étnicas, especialmente la gitana.

IDIOMA: Castellano.

CORREO ELECTRÓNICO: webmaster@cnice.mecd.es

Dirección General de Inmigración, Voluntariado y Otros Colectivos. Comunidad Autónoma de Murcia. Consejería de Trabajo y Política Social INTERNET: http://www.carm.es/ctra/centros.asp?id = 10

objetivos: Puesta en marcha, seguimiento y evaluación de planes y programas relacionados con inmigración, voluntariado y otros colectivos, así 
como elaboración y gestión de los convenios que se deriven de los planes y programas mencionados.

RESUMEN DE SUS CONTENIDOS: En el apartado relativo a inmigración se pueden consultar los planes concretos a los que antes se ha hecho referencia, así como un compendio de legislación de ámbito estatal y autonómico relativo a la inmigración, información sobre trámites a realizar relacionados con extranjería y un catálogo de publicaciones sobre temas inmigratorios. IDIOMA: Castellano.

CORREO ELECTRÓNICO: cdss@carm.es

\section{EMSI. Escuela de Mediadores Sociales para la Inmigración}

INTERNET: http://www.madrid.org/emsi/presentacion/objetivos.htm

oBJetivos: Contribuir a la integración plena en la sociedad madrileña de las personas y colectivos de origen extranjero y autóctono, mediante la formación en inmigración, mediación e interculturalidad.

RESUMEN DE SUS CONTENIDOS: Organiza cursos, actividades (taller de teatro, conferencias, concursos de cuentos interculturales). Ofrece información sobre publicaciones de contenido multicultural y dispone de soporte bibliográfico a alumnos, docentes y a todas aquellas personas interesadas. Se ha gestado el Servicio de Documentación, que brinda a través del préstamo y/o consulta, una variada literatura sobre inmigración, mediación e interculturalidad. El Servicio cuenta con más de 750 libros y materiales clasificados en diferentes campos. El acceso es libre y gratuito en el horario establecido por la Escuela.

IDIOMA: Castellano.

CORREO ELECTRÓNICO: emsi@madrid.org

\section{Entreculturas. Junta de Andalucía. Consejería de Cultura}

INTERNET: http://www.juntadeandalucia.es/cultura/ba/c/

oBJETivos: Proporcionar recursos de información para minorías étnicas, culturales y lingüísticas residentes en Andalucía.

RESUMEN DE SUS CONTENIDOS: Ofrece una clasificación bastante completa de recursos de utilidad relativos a diez grandes temas: atención jurídica, conocer España, cultura, educación, empleo, organizaciones, asociaciones y colectivos de apoyo a la inmigración, recursos en otros países, seguridad social, sociedad y política. La mayor aportación de esta web es la posibilidad de ser consultada en otras lenguas, como el árabe, atendiendo a las cada vez más urgentes necesidades de ciudadanos procedentes 
del otro lado del Mediterráneo con escasos conocimientos de castellano. El Plan Integral de Atención a la Inmigración en Andalucía, al que pertenece dicha guía, persigue favorecer la plena integración social, laboral y personal de los inmigrantes en el seno de la sociedad andaluza. Dentro de este marco de actuación se pone en marcha el «Proyecto de Bibliotecas Multiculturales en Andalucía» entendiendo que las bibliotecas públicas son el lugar donde se facilita el acceso a la información.

IDIOMA: Castellano, inglés, francés, rumano, polaco, ruso, árabe.

CORREO ELECTRÓNICO: entreculturas.ba.ccul@juntadeandalucia.es

IMSERSO. Instituto de Migraciones y Servicios Sociales. Observatorio Permanente de la Inmigración

INTERNET: http://www.imsersomigracion.upco.es/

OBJETIVos: Entidad Gestora de la Seguridad Social para la gestión de los Servicios Sociales complementarios de las prestaciones del Sistema de Seguridad Social en materia de mayores y discapacidad.

RESUMEN DE SUS CONTENIDOS: Se puede encontrar en esta página información sobre todo lo relacionado con el proceso de integración de la población extranjera en el Estado español. Gran cantidad de datos estadísticos, publicaciones, campañas informativas, documentos, acciones de formación, links, análisis de medios de comunicación, normativa legal y campañas. IDIOMA: Castellano.

CORREO ELECTRÓNICO: buzon.imserso@mtas.es

\section{Ministerio de Asuntos Exteriores}

INTERNET: http://www.mae.es/

OBJETIVOS: Los propios de un ministerio de exteriores.

RESUMEN DE SUS CONTENIDOS: Direcciones de embajadas y consulados de todos los países con los que el Estado español mantiene relaciones diplomáticas. Listados del cuerpo diplomático acreditado en el país y listas consulares. Teléfonos de la oficina de información administrativa y del departamento de legalizaciones.

IDIOMA: Castellano.

CORREO ELECTRÓNICO: webmaster@mae.es.

\section{Ministerio del Interior}

INTERNET: http://www.mir.es/

OBJETIVOS: Los propios de un ministerio de interior. 
RESUMEN DE SUS CONTENIDOS: La página ofrece información sobre normativa y jurisprudencia en materia de extranjería e inmigración. También tiene un apartado de modelos y solicitudes de trámites burocráticos relacionados con la situación de inmigrado. Pone a disposición del público una sección de estadística desde la que se puede acceder a los diversos Anuarios Estadísticos de Extranjería publicados hasta la fecha, informes estadísticos sobre los extranjeros con tarjeta, boletines estadísticos y datos sobre la inmigración irregular por medio de embarcaciones. Permite el acceso al Foro para la integración social de los inmigrantes, donde se pueden realizar preguntas y sugerencias y recibir información sobre las actuaciones llevadas a cabo para la integración de los nuevos ciudadanos. Permite el acceso al Observatorio Permanente de la Inmigración y a un apartado de actualidad en el que están reflejadas las últimas noticias producidas en el ámbito de la inmigración.

IDIOMA: Castellano, inglés, francés y algunas secciones en árabe.

CORREO ELECTRÓNICO: extranjeros@mir.es

OFRIM. Oficina Regional para la Inmigración de la Comunidad de Madrid. Consejería de Servicios Sociales

INTERNET: http://www.comadrid.es/cservicios_sociales/index_inmigra.htm OBJETIVOs: Información y asesoramiento especializados, dirigidos preferentemente a instituciones y profesionales que desarrollan su actividad con inmigrantes.

RESUMEN DE SUS CONTENIDOS: Recopilación de entidades y recursos, tanto públicos como privados, con actuaciones destinadas a facilitar la integración de los inmigrantes madrileños.

IDIOMA: Castellano.

CORREO ELECTRÓNICO: oficina.atencion.ciudadano@madrid.org

\section{REICAZ. Real e Ilustre Colegio de Abogados de Zaragoza}

INTERNET: http://www.extranjeria.info/

OBJETIVOs: Los propios de un colegio profesional.

RESUMEN DE SUS CONTENIDOS: Dispone de una muy interesante área jurídica que pone a disposición del usuario todas las leyes relacionadas con la inmigración, impresos de regularización, asilo, servicios sociales, etc. Links a diversas organizaciones y ONGs. También se puede consultar un kiosco de prensa con los artículos más interesantes sobre el tema y una sección donde se recogen todas las novedades relacionadas con la inmigración. 
Están referenciadas también todas las asociaciones federadas del territorio estatal.

IDIOMA: Búlgaro, alemán, árabe, chino, francés, inglés, polaco, portugués, rumano, ruso y castellano.

CORREO ELECTRÓNICO: extranjeria@reicaz.es

Subdirección General de Títulos. Convalidaciones y Homologaciones. Ministerio de Educación y Ciencia

INTERNET: http://wwwn.mec.es/mecd/titulos/

OBJETivos: Homologación de títulos extranjeros

RESUMEN DE SUS CONTENIDOS: Información sobre como solicitar el reconocimiento de títulos, universitarios y de otros niveles educativos, extranjeros en el Estado español, así como reconocer los títulos regulados por las directrices de la Unión Europea. Pueden también encontrarse los diferentes modelos de solicitud para la realización de los trámites pertinentes. Proporciona las direcciones de los diversos centros y puntos de información en España y en el extranjero en las que se puede encontrar información sobre el tema. Pone a disposición de todos los interesados una amplia información sobre cursos de castellano para extranjeros.

IDIOMA: Castellano.

CORREO ELECTRÓNICO: Tiene acceso pero no explicita su dirección.

\section{UGT. Migraciones}

INTERNET: http://www.ugt.es/inmigracion/foroinmigracion.html OBJETIVOS: Los propios de una organización sindical.

RESUMEN DE SUS CONTENidos: Página de direcciones de todas las sedes del sindicato en el Estado español, así como la legislación y noticias relacionadas con la inmigración en sus aspectos laborales, sociales y legales. IDIOMA: Castellano.

CORREO ELECTRÓNICO: migraciones@cec.ugt.org 


\section{Asociaciones, fundaciones y ONGS}

\section{ACCEM. Asociación Comisión Católica Española de Migración}

INTERNET: http://www.accem.es/

objetivos: Prestar servicio a los refugiados e inmigrantes que se encuentran en España, promoviendo su inserción en nuestra sociedad a todos los niveles. Buscar un acercamiento, desde la comprensión y el aprendizaje mutuo, entre la sociedad española y las personas migrantes, quienes ya forman parte integrante de nuestro entorno, aunque no siempre disfruten de las mismas condiciones y derechos.

RESUMEN DE SUS CONTENIDOS: Información, orientación, asesoramiento legal, de emergencia a grupos vulnerables, inserción laboral, reasentamiento en terceros países. Boletín "EUMIGRE» que informa sobre programas europeos, ayudas, subvenciones, estadísticas, noticias de Europa, páginas web de interés, eventos, publicaciones, etc. y pone a disposición de cualquier persona interesada un foro público de consultas para realizar sus preguntas, dudas, consultas, sugerencias, etc.

ÁmBito de aCtuación o de implantación: Asturias, León, Burgos, Girona, Madrid, Toledo, Guadalajara, Cuenca, València y Sevilla.

IDIOMA: Castellano.

CORREO ELECTRÓNICO: accem@accem.es

\section{AMDE. Asociación de Mujeres Dominicanas en España}

INTERNET: http://www.eurosur.org/AMDE/amde.htm

objetivos: Dar respuesta al problema del creciente número de inmigrantes dominicanos en esta ciudad. A la asociación se han integrado muchas otras mujeres (y hombres) dominicanas/os de todos los sectores.

RESUMEN DE SUS CONTENIDOS: Información y orientación jurídico-laboral, guía socio-laboral para las mujeres dominicanas en Madrid, información sobre cursillos, talleres y grupos de apoyo. Recogida de denuncias.

ÁMBITO DE ACTUACIÓN O DE IMPLANTACIÓN: Madrid.

IDIOMA: Castellano.

CORREO ELECTRÓNICO: amde@eurosur.org 


\section{Arabismo.com}

INTERNET: http://www.arabismo.com/

OBJETIVOS: Arabismo.com es una asociación sin ánimo de lucro, formada por profesores de lengua árabe y otras personas interesadas en el estudio y difusión de esta lengua. Se propone crear un servicio por internet orientado a los estudios de lengua árabe, dirigido tanto a los especialistas como a los estudiantes universitarios y no universitarios.

RESUMEN DE SUS CONTENIDOS: Información para todas aquellas personas que están interesadas y relacionadas con la lengua y la cultura árabes. Librerías, universidades, portales, publicaciones, prensa, software para arabizar el PC e internet.

ÁMBITO DE ACTUACIÓN O DE IMPLANTACIÓN: Estatal.

IDIOMA: Castellano.

CORREO ELECTRÓNICO: miguel.manzano@arabismo.com

\section{Asociación Bayt Al-Thaqafa}

INTERNET: http://bayt-al-thaqafa.org/index.html

OBJETIVos: Asociación creada en 1974 para facilitar la integración cultural y social de los inmigrantes arabo-musulmanes residentes en Catalunya, sin pérdida de su propia identidad, así como mostrar su diversidad cultural y dar a conocer la realidad de los países árabes y el Islam.

RESUMEN DE SUS CONTENIDOS: Dispone de biblioteca especializada en temas de inmigración, mundo árabe y cultura islámica que cumple una doble función: formar al personal del Bayt y ser un centro abierto para Barcelona. También proporciona información práctica sobre todos los problemas con los que se enfrentan los nuevos ciudadanos.

ÁMBITO DE ACTUACIÓN O DE IMPLANTACIÓN: Catalunya.

IDIOMA: Castellano.

CORREO ELECTRÓNICO: bayt@bayt-al-thaqafa.org

\section{Asociación Española de Enseñantes con Gitanos}

INTERNET: http://www.pangea.org/aecgit

oBjetivos: Asociación no gubernamental, vinculada al Pueblo Gitano, que pretende contribuir a la desaparición de actitudes de discriminación e intolerancia y que trabaja para el entendimiento, la solidaridad y la comunicación entre todos los pueblos, etnias y culturas.

RESUMEN DE SUS CONTENIDOS: Interesante sección de recursos (bibliografía, guías y materiales audiovisuales) y de una agenda con los datos de todos sus centros a lo largo de la geografía del estado. 
ÁMBiTO DE ACTUACIÓN O DE IMPLANTACiÓN: Todo el estado.

IDIOMA: Castellano e inglés.

CORREO ELECTRÓNICO: aecgit@pangea.org

\section{Asociación Nexos}

INTERNET: http://www.nodo50.org/nexos/biblioteca.htm

oBjetivos: La finalidad principal de esta asociación es la promoción y organización de los sectores sociales en situación de desventaja social, con especial atención a niños, jóvenes, parados, mujeres, tercera edad en precariedad socio-laboral, grupos sociales urbanos y rurales; minorías étnicas y/o culturales, migrantes; minusválidos y toxicómanos.

RESUMEN DE SUS CONTENIDOS: Permite la consulta on line de los catálogos de la biblioteca cedida por el equipo Colectivo Ioé, organizados por libros, documentos y revistas, según temáticas y autores. También ofrece la dirección y horario de la ubicación física de dicha biblioteca.

ÁMBITO DE ACTUACIÓN O DE IMPLANTACIÓN: Red.

IDIOMA: Castellano.

CORREO ELECTRÓNICO: nexos@nodo50.org

\section{ASTI. Asociación de Solidaridad con los Trabajadores Inmigrantes}

INTERNET: http://www.asti-madrid.com/

obJETIVos: Asesoramiento, apoyo legal y defensa jurídica; integración y desarrollo armónico de la persona y de la familia inmigrantes; formación básica: lengua y cultura españolas, alfabetización, graduado escolar, capacitación profesional.

RESUMEN DE SUS CONTENIDOS: Publicaciones de ayuda y conocimiento de la realidad de la inmigración en el área de Madrid. Completa información sobre la legislación de inmigración.

Ámbito de ACTUACión o DE IMPLANTACión: Madrid, Getafe y Alcalá de Henares.

IDIOMA: Castellano.

CORREO ELECTRÓNICO: asti@asti-madrid.com

ATIME. Asociación de Trabajadores e Inmigrantes Marroquíes en España INTERNET: http://www.atime.es/

OBJETIVOs: Atender y dar cobertura a las demandas del numeroso colectivo de inmigrantes en España, pero también con una clara vocación reivindicativa, en cuyo fondo subyace la idea principal de conseguir que el 
inmigrante sea considerado plenamente como un ciudadano más, con sus derechos pero también con sus obligaciones.

RESUMEN DE SUS CONTENIDOS: Asesoramiento en materia de documentación y laboral, tramitación del permiso de trabajo, reagrupación familiar, etc. Programa Salima (dinamización grupal de la mujer magrebí y asistencia para mujeres maltratadas). Servicios de interpretación y traducción. ÁMBITO DE ACTUACIÓN O DE IMPLANTACIÓN: Estatal. IDIOMA: Castellano.

CORREO ELECTRÓNICO: atimeestatal@telcom.es/atime@telcom.es/

\section{Canalsolidario.org (Oneworld España)}

INTERNET: http://www.canalsolidario.org/web/directorio_ong/directorio _ong.asp?busqueda = ver\&id_ong $=908$

oBjetivos: Proyecto de comunicación sobre cooperación, desarrollo, paz, derechos humanos e inclusión social que desde 1999 ofrece a través de un portal de internet información de actualidad, servicios, recursos y espacios de participación social. Trabajan por una comunicación libre, participativa y plural, comprometida con el desarrollo de las personas y pueblos de todo el mundo, que actúe como motor de cambio hacia una sociedad más incluyente y justa. Miembro de la red Oneworld.net.

RESUMEN DE SUS CONTENIDOS: Noticias, alertas sobre conflictos, reclutamiento de voluntariado, asesoría para organizaciones solidarias, buscador de publicaciones, información sobre cursos de formación. Buscador de las más de dos mil entidades suscritas a la organización en España y el extranjero.

ÁMBITO DE ACTUACIÓN O DE IMPLANTACIÓN: Estatal e internacional.

IDIOMA: Castellano y catalán. La red Oneworld.net trabaja también en once idiomas.

CORREO ELECTRÓNICO: Tiene acceso pero no consta dirección.

\section{CAR. Centros de Acogida a Refugiados. Imserso}

INTERNET: http://www.vadevallecas.org/cabecera/INMIGRANTES/CAR.htm obJETIvos: Facilitar el proceso de integración social de los solicitantes de asilo.

RESUMEN DE SUS CONTENIDOS: LOS CAR son establecimientos públicos que prestan, con carácter temporal, alojamiento, manutención, asistencia psicosocial, etc., así como otros servicios sociales encaminados a facilitar la integración sociocomunitaria de las personas que soliciten la condición 
de refugiado en España y que carezcan de medios económicos para atender sus necesidades y las de su familia.

ÁMBiTO DE ACTUACIÓN O DE IMPLANTACIÓN: Estatal.

IDIOMA: Castellano.

CORREO ELECTRÓNICO: accem@sintax.es

\section{CEAR. Comisión Española de Ayuda al Refugiado}

INTERNET: http://www.cear.es/home.php

OBJETIVOS: Poner al alcance de todos los interesados toda la información relevante sobre las acciones llevadas a cabo por la organización y la situación de los refugiados e inmigrantes que llegan a nuestras fronteras. Difundir y denunciar públicamente las situaciones de indefensión y/o violación del derecho de asilo y, por otro, promover la participación y sensibilización de los ciudadanos y los agentes sociales. Prestar atención jurídica y social e impulsar la integración laboral del colectivo.

RESUMEN DE SUS CONTENIDOS: Fondo documental de libros, registros históricos de periódicos catalogados por continentes y países, documentales sobre la situación de los derechos humanos en diferentes países, documentos y monografías relativos al asilo, racismo, mujeres, xenofobia. Recopilación de legislación, tanto internacional como estatal y noticias. También pone a disposición del público una serie de links sobre la situación de los derechos humanos en el mundo.

ÁmBito de ACtUACiÓn o de IMPLANTACIÓn: Euskadi, Andalucía, Ceuta, Meli1la, Extremadura, Catalunya, Canarias y País Valencià.

IDIOMA: Castellano.

CORREO ELECTRÓNICO: cendocent@cear.es

CEPAIM. Consorcio de Entidades para la Acción Integral con Inmigrantes INTERNET: http://www.cepaim.org/

oBJeTivos: La elaboración y ejecución de programas formativos, sociales y de inserción sociolaboral que incidan en el tratamiento e integración de inmigrantes y personas refugiadas, menores, jóvenes, mujeres y familias, en el tratamiento positivo e intercultural que el impacto migratorio genera en las sociedades de acogida, así como en los procesos de inclusión social, para facilitar su inserción y convivencia en el ámbito del Estado español y en el conjunto de la Unión Europea, favoreciendo siempre las relaciones interculturales. Favorecer la igualdad de género entre mujeres y hombres. 
RESUMEN DE SUS CONTENidos: Pone a disposición del inmigrante la red de centros ITACA para ayudar al inmigrante en la obtención de un empleo y en su inserción sociolaboral.

Ámbito de actuación o de implantación: Murcia, Almería, Sevilla, Madrid, València, Zaragoza y Barcelona (Centros ITACA).

IDIOMA: Castellano.

CORREO ELECTRÓNICO: info@cepaim.org

\section{Con Papeles.com}

INTERNET: http://www.conpapeles.com/

oBJETIVOS: Web destinada a proporcionar soporte jurídico.

RESUMEN DE SUS CONTENIDOS: Proporciona asesoramiento para la realización de cualquier trámite relacionado con la normalización de un ciudadano alóctono (visas, homologaciones, actualizaciones de residencia, obtención de nacionalidad, reagrupación familiar, etc.). Puede también solicitarse defensa jurídica y formularse preguntas al abogado.

ÁMBITO DE ACTUACIÓN O DE IMPLANTACIÓN: Estatal.

IDIOMA: Castellano e inglés.

CORREO ELECTRÓNICO: Tiene acceso pero no consta dirección.

\section{Democracia.web}

INTERNET: http://www.democraciaweb.org/

OBJEtivos: Promovida por la fundación Jaume Bofill, con el apoyo de la Mesa del Parlament de Catalunya y la colaboración de la Uoc (Universitat Oberta de Catalunya). El objetivo de Democracia Web es favorecer la información y el debate así como la participación ciudadana a través de la red, impulsando la comunicación entre los ciudadanos y sus representantes políticos. Es, en definitiva, una plataforma de democracia electrónica.

RESUMEN DE SUS CONTENIDOS: Agenda parlamentaria de Catalunya que permite el acceso a todos los proyectos de ley que se debaten o se han debatido en el parlamento catalán. Organización de chats (no-periódicos) con políticos catalanes sobre temas diversos de actualidad, inmigración incluida. Acceso a un archivo de legislación de la séptima legislatura. Pero lo que quizás supone la aportación más novedosa es la existencia de un canal de propuestas de enmiendas de ley a través del cual cualquier ciudadano puede intervenir en el proceso legislativo.

Ámbito DE ACTUACiÓN O DE IMPLANTACión: Estado español y Països Catalans. 
IDIOMA: Catalán, castellano e inglés.

CORREO ELECTRÓNICO: fbofill@fbofill.org

\section{Derechos paraTod@s}

INTERNET: http://www.nodo50.org/derechosparatodos/

OBJETIVOS: Luchar contra la exclusión y todas sus manifestaciones y actuar en sus causas e intervenir directamente contra la globalización neoliberal. RESUMEN DE SUS CONTENIDOS: En su sección de inmigración dispone de textos sobre inmigración y racismo, informaciones y noticias sobre la problemática a la que se enfrentan los nuevos ciudadanos así como de noticias sobre encierros y actos de protesta. Ofrece también información jurídica sobre el reglamento de extranjería y una guía para la regularización.

ÁMBITO DE ACTUACIÓN O DE IMPLANTACIÓN: Estatal.

IDIOMA: Castellano.

CORREO ELECTRÓNICO: derechos@nodo50.org

\section{EDUALTER}

INTERNET: http://www.edualter.org/

OBJETIVOS: Fomento de la educación en la diversidad y la multiculturalidad. RESUMEN DE SUS CONTENIDOS: Dispone de más de 800 fichas de libros y materiales (vídeos, juegos,) publicados sobre educación para la paz, la interculturalidad y el desarrollo, así como de una selección de películas que tratan diferentes aspectos de la relación entre culturas. Temas como el racismo, la intolerancia, la marginación, o la discriminación aparecen concretados en la trama argumental de las mismas. Proponen ofrecer unas pautas de análisis para determinar el sentido de las historias que se relatan y, por lo tanto, valorar la perspectiva que ofrecen en relación al tema tratado. También se puede encontrar un listado de personas y de grupos que trabajan o están relacionados con la educación para la paz, el desarrollo y la interculturalidad.

ÁMBITO DE ACTUACIÓN O DE IMPLANTACIÓN: Estatal.

IDIOMA: Castellano y catalán.

CORREO ELECTRÓNICO: edualter@pangea.org

FAIB. Sense Fronteres. Federació d'Associacions d'Immigrants a Balears INTERNET: http://www.inmigracionfaib.org/

OBJETIVOS: La FAIB está compuesta por diez asociaciones. Los servicios que se prestan están dirigidos a la población inmigrada y a nacionales. 
RESUMEN DE SUS CONTENIDOS: Servicios de asesoramiento e información. Mediación intercultural, traducciones e interpretaciones. Los fondos documentales que componen este centro han sido adquiridos a través de donaciones realizadas por varias instituciones. Hemeroteca y videoteca.

ÁMBITO DE ACTUACIÓN O DE IMPLANTACIÓN: Illes Balears.

IDIOMA: Castellano.

CORREO ELECTRÓNICO: inmigrafaib@inmigracionfaib.org/abogadas@inmigracionfaib.org

\section{FSGG. Fundación Secretariado General Gitano}

INTERNET: http://www.fsgg.org/servicios/documentacion/contacto.htm

OBJETIVOS: Luchar por la dignidad, la justicia y la mejora de la imagen social de la comunidad gitana, promoviendo su ciudadanía y el ejercicio pleno de sus derechos en la sociedad.

RESUMEN DE SUS CONTENIDOS: Dispone de un centro de documentación especializado en temas relacionados con la comunidad gitana (historia, cultura, informes, estudios sociológicos).

ÁMBITO DE ACTUACIÓN O DE IMPLANTACIÓN: Europa.

IDIOMA: Castellano e inglés.

CORREO ELECTRÓNICO: documentacion@fsgg.org

\section{GRAMC. Grup de Recerca i Actuació amb Minories Culturals i Treballa- dors Estrangers}

INTERNET: http://www.gramc.org/

OBJETIVOs: Acoger y formar trabajadores extranjeros y sus familias, así como impulsar la educación en actitudes favorables a la solidaridad, la convivencia multicultural y la erradicación del chauvinismo en la sociedad de acogida. Se ocupa también de la formación y reciclaje de profesionales especializados en temas relacionados con la inmigración y la interculturalidad.

RESUMEN DE SUS CONTENIDOS: Publicaciones sobre educación sanitaria desde una perspectiva multicultural, una Guía para trabajadores y trabajadoras extranjeros, y dispone de un aula de derecho de extranjería, donde se puede encontrar un compendio de legislación en vigor sobre inmigración.

ÁMBITO DE ACTUACIÓN O DE IMPLANTACIÓN: Girona.

IDIOMA: Catalán.

CORREO ELECTRÓNICO: minories@gramc.org 


\section{Observatorio Vasco de la Inmigración}

INTERNET: http://www.euskadi.net

objetivos: Se trata de un nuevo órgano de asesoramiento que tiene como objetivos servir de cauce de participación y diálogo, recoger las aspiraciones y demandas de la población inmigrante y las propuestas tendentes a promover la integración de las y los ciudadanos inmigrantes, todo ello a fin de posibilitar la participación social.

RESUMEN DE SUS CONTENIDOS: Consultar, informar y asesorar en la planificación de las actuaciones de la administración en materia de inmigración. IDIOMA: Eusquera, castellano, inglés, francés y alemán.

CORREO ELECTRÓNICO: elarrinaga@getxo.net_ibarrencua@getxo.net

\section{PANGEA. Internet Solidario}

INTERNET: http://www.pangea.org/

OBJETIVos: Es una plataforma para servir a las organizaciones de todo tipo que trabajan por la justicia social.

RESUMEN DE SUS CONTENIDOS: Bolsa de trabajo para poner en contacto organizaciones sin ánimo de lucro que busquen trabajadores (remunerados o no) con aquellas personas dispuestas a colaborar. Una agenda informativa en la que se puede encontrar información de los actos organizados dentro del ámbito de la lucha por la justicia social. Un directorio de recursos, uno de cuyos apartados esta dedicado especialmente a la inmigración e interculturalidad, que muestra información de toda una serie de enlaces y recursos relacionados directamente con las migraciones. ÁMBITO DE ACTUACIÓN O DE IMPLANTACIÓN: Barcelona.

IDIOMA: Catalán y castellano.

CORREO ELECTRÓNICO: suport@pangea.org

\section{RASINET. Red de Apoyo Social al Inmigrante}

INTERNET: http://www.rasinet.org/

OBJETIVOs: Integrada por doce instituciones - públicas y privadas - de la Región de Murcia preocupadas por el tema de la inmigración, entre las que se encuentra el Ayuntamiento de Murcia, promotor de la iniciativa, y el Instituto de Servicios Sociales de la Región de Murcia. En sus objetivos está el crear un espacio de coordinación e información, que contribuya a mejorar la intervención en el mundo de la inmigración, así como ofrecer alternativas en distintos temas (la sanidad, la formación, la información en general...). 
RESUMEN DE SUS CONTENIDOS: Dispone de hemeroteca, archivo, formularios para realizar quejas y denuncias on line. En el ámbito del acogimiento cuenta con una Bolsa de Alojamientos.

ÁMBITO DE ACTUACIÓN O DE IMPLANTACIÓN: Región de Murcia.

IDIOMA: Castellano.

CORREO ELECTRÓNICO: rasinet@rasinet.org

\section{Red Acoge. Federación de Asociaciones pro Inmigrantes}

INTERNET: http://www.redacoge.org/

OBJETIVOs: Acogida de las personas inmigrantes y apoyo integral en todas las demandas que las personas inmigrantes plantean para conseguir su integración en la sociedad española. Defensa de la dignidad humana y de las personas en situación documental irregular. Compromiso con la igualdad de todos los seres humanos, tanto en el ejercicio de los derechos como en el cumplimiento de los deberes. Defensa de un modelo de ciudadanía, no configurado a partir de la nacionalidad y capaz de conjugar igualdad y diversidad humana.

RESUMEN DE SUS CONTENIDOS: Descarga de modelos de solicitud de normalización, contratos de trabajo. Información sobre cada una de las asociaciones de la red distribuidas por todo el territorio estatal, enlaces con otras organizaciones o entidades de interés.

ÁMBITO DE ACTUACIÓN: La mayor parte del territorio estatal (consultar mapa de la web).

IDIOMA: Castellano.

CORREO ELECTRÓNICO: acoge@redacoge.org

\section{sos Racisme Catalunya}

INTERNET: http://www.sosracisme.org/

OBJETIVOS: Asociación no gubernamental antirracista, pluriétnica y progresista para la defensa de los derechos humanos, contra el racismo y la xenofobia.

RESUMEN DE SUS CONTENIDOS: Pone a disposición del público una sección de recursos pedagógicos (material didáctico y exposiciones) así como una sección de información y denuncias de todo tipo de situaciones racistas y xenofóbicas.

ÁMBITO DE ACTUACIÓN O DE IMPLANTACIÓN: Catalunya.

IDIOMA: Catalán.

CORREO ELECTRÓNICO: sosracisme@sosracisme.org 


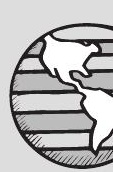

Bibliografía 
ACNuR (2000): The state of the World's Refugees 2000. Fifty years of humanitarian action, New York, Oxford University Press Inc.

-(2004): Los refugiados en cifras, 2003. www.acnur.org

AJA, E. y otros (2000): La inmigración extranjera en España, Barcelona, Colección de estudios sociales, 1, Fundación «la Caixa».

Alañón Pardo, A. y M. Gómez de AntoNIO (2003): Una evaluación del grado de incumplimiento fiscal para las provincias españolas, Comissió Europea, Papers de Treball 9/2003.

AlCAide, C. (2004): «La importancia de conocer la inmigración", Economía Exterior, 28, pp. 9-14.

Álvarez Dorronsoro, I. (1998): La negociación de la diversidad cultural en las sociedades multiétnicas y pluriculturales modernas. Trabajo presentado en el Curso Políticas Sociales, Intervención Social e Inmigración desarrollado en la Universidad Internacional de Andalucía (Sede Antonio Machado de Baeza) del 31 de agosto al 4 de septiembre de 1998.

AmbrosinI, M. (1998): “"Intereses ocultos”. La incorporación de los inmigrantes a la economía informal», Migraciones, 4. ANDRÉS, J., J. ANDRÉS y E. RAMIRO I ROCA (1998): «Llengua i territori a la Ribe- ra Baixa», II Jornades d'Història Local, Ajuntament de Cullera.

ARANGo, J. (2002): «La fisonomía de la inmigración en España», Red de Migración y Desarrollo, http://www. migracionydesarrollo.com

- (2003 a): «Europa, ¿una sociedad multicultural en el siglo xxi? El caso de España", Papeles de Economía Española, 98, pp. 2-15.

- (2003 b): «La población inmigrada en España», Economistas, 99, pp. 6-14.

Aubarell, G. y R. ZaPATA, (eds.) (2004): Inmigración y procesos de cambio, Barcelona, Icaria.

Baganha, M. y Reyneri, E. (2001): «La inmigración en los países del sur de Europa y su inserción en la economía informal», en Carlota Solé: El impacto de la inmigración en la economía y en la sociedad receptora, Anthropos, Barcelona, pp. 53-211.

Barata, O. S. (2003): Demografia e Sistema Internacional, Lisboa, UTL.

Bareda, A. (1985): Dialéctica de la identidad catalana, Madrid, Centro de Investigaciones Sociológicas.

BARRADA, A. (2003): «Inmigración y Seguridad Social», Papeles de Economía Española, 98, pp. 124-145.

BARRY BRIAN, M. (1991): Democracy and power. Essays in political theory, Oxford, Clarendon. 
Beine, M., F. Docquier y H. Rapopport (2001): «Brain Drain and Economic Growth: Theory and Evidence», Journal of Developement Economics, 64, 1, pp. 275-289.

BERG, A. y otros (1999): «The Evolution or Output in Transition Economies: Explaining the Differences», Washington, IMF Working Paper n. ${ }^{0}$ wP/99/73, International Monetary Found. DC.

Bergua, J. (1934): Psicología del Pueblo Español, Madrid, Librería Bergua.

Blanco, C. (2000): Las migraciones contemporáneas, Madrid, Alianza.

Bolzman, C. (1999): Políticas de inmigración. Derechos humanos y ciudadanía a la hora de la globalización: una tipología, Repensando una ciudadanía, Fundación El Monte, pp. 203-227.

Bustamante, J. A. y G. G. Martínez (1979); «Undocumented Immigration from Mexico: Beyond Borders but within Systems", Journal of International Affairs, 33, pp. 265-279.

BuxarRaIs, R. M. ${ }^{a}$ y otros (1991): Linterculturatisme en el currículum. El racisme, Barcelona, Dossiers de Rosa Sensat.

CABré, A. (1995): «Notes sobre la Transició familiar» en Jornades sobre família i canvi social, Barcelona, Servei de Documentació i Difusió de l'Associació de les Nacions Unides a Espanya, pp. 31-46.

CABré, A. y otros (2000): Demografía: una cuestión de dos sexos y cuatro generaciones. Informe realizado por el Centre d'Estudis Demogràfics, para la Dirección V de la Comisión Europea, Empleo, Relaciones Industriales y Asuntos Sociales. Mimeo.

Cabré, A., A. Domingo y T. Menacho (2002): «Demografía y crecimiento de la población española durante el siglo XX», en Mediterráneo Económico, $n{ }^{\circ}$ 1, Monográfico: Pimentel Siles, M. (coord.). Procesos Migratorios, economía y personas, pp. 121-138, Almería, Caja rural intermediterránea, Cajamar.

CACHÓN, L. (2003): «La inmigración en España: los desafíos de la construcción de una nueva sociedad", Migraciones, 14, pp. 219-304.

-(2004): «Inmigración y mercado de trabajo en España", Economía Exterior, 28, pp. 49-57.

Calvo Buezas, T. (1989): Los racistas son los otros. Gitanos, minorías y Derechos Humanos en los Textos Escolares, Madrid, Popular.

CARvajal Gómez, M. I. (2003): «Los inmigrantes en la Seguridad Social: estado de su afiliación y clases de prestaciones a las que pueden acceder", en Andrés Tornos (ed.): Los inmigrantes y el mundo del trabajo, Universidad Pontificia Comillas, Madrid, pp. 235266.

CASAls, C. (2004): Expulsados de su tierra, Lleida, Milenio.

CASTAÑo, Á. (2000): Informe 2000 sobre la inmigración en Almería, Consejería de Asuntos Sociales, Junta de Andalucía.

CAstells, M. (1998): La era de la información: economía, sociedad y cultura. II. El poder de la identidad, Madrid, Alianza.

Castles, S. y M. J. Miller (1998): The Age of Migration. Internactional Population Movements in the Modern World, New Yord-London, The Guilford Press. CEIM (2002): Impacto mediático de la inmigración en la Comunidad Valenciana, Valencia, Generalitat Valenciana. 
CeP de València (1994): Bibliografia i materials per treballar la interculturalitat, València.

Cercelescu, Gh. (1999): The Romanian Informal sector, US Treasury Report, Whashington.

Cinca, J. y D. Allona (2002): «Permisos de trabajo a extranjeros en España", Fuentes Estadísticas, 69. http://www. fuentesestadisticas.com/

Clavijo, C. y M. Aguirre (eds.) (2002): Politicas sociales y Estado de Bienestar en España: las migraciones, Madrid, Fundación Hogar del Empleado.

Colectivo Ioe (1999): Inmigrantes, trabajadores, ciudadanos, Valencia, Universitat de València-Patronat Sud-Nord. - (2000 a): «Flujos migratorios internacionales. Marco de comprensión y características actuales», Migraciones, 9. -(2000 b): Mujer, inmigración y trabajo, Madrid, Ministerio de Trabajo y Asuntos Sociales.

-(2002): Immigració, escola i mercat de treball. Una radiografia actualitzada, Barcelona, Fundació «la Caixa».

Col-lectiu Amani (1994), Educación Intercultural. Análisis y resolución de conflictos, Madrid, Popular.

Constantin, D. L. y otros (2004): The Migration Phenomenon from the Perspective of Romania's Accesion to the European Union, Bucarest, Study, 5, European Institut of Romania.

DD.AA. (1995): Escola Catalana, 322 dedicat a Interculturalitat i Ensenyament.

De LucAs, J. y S. PeÑA (2001): Trabajadores migrantes, Alzira, Germania.

De Lucas, J. y F. TORRes (2002): Inmigrantes: ¿cómo los tenemos?, Madrid, Talasa.

De Soto, H. G. y N. Dudwick (1997): Poverty in Moldova: The Social Dimen- sions of Transition, World Bank, Technical paper, 1.

Díez Nicolàs, J. (1999): Identidad nacional y cultura de Defensa, Madrid, Síntesis.

Dimaggio, P. (1997): "Culture and Cognition", Annual Review of Sociology, XXIII, pp. 263-287.

Diminescu, D. (2003): Visible mais peu nombreux, Paris, Editions de la Maison des sciences de l'Homme.

Dochia, A. (1999): «New Private Firm Contribution to Structural Change in the Romanian Economy", en Romania 2000-10 Years of Transition, Romanian Centre for Economic Policies and The World Bank Treasury.

Domingo, A. (2002): «Reflexiones demográficas sobre la inmigración internacional en los países del sur de la Unión Europea» en Actas del $3^{\text {er }}$ Congreso de la Inmigración en España, vol I, Granada, pp. 197-212.

Domingo Pérez, C. (2002): «Cifras de población y características de los extranjeros censados en el País Valenciano", Cuadernos de Geografía, 72, pp. 207230.

Domingo, C. y R. Viruela (2001): "Cadenas y redes en el proceso migratorio español», Escripta Nova. Revista electrónica de Geografía y Ciencias Sociales, UB, 94 (8) [SIN 1138-9788]. http:// www.ub.es/geocrit/sn94-8.htm

DUPÂQUIER, J. (2002): A populaçao mundial no século XX, Lisboa, Instituto Piaget.

DwORKIN, R. (1984): El modelo de las normas (I). En Los derechos en serio, Barcelona, Ariel (publicado originalmente en inglés en 1977).

EsPARCIA PÉREZ, J. (2002): «La creciente importancia de la inmigración en las 
zonas rurales de la Comunidad Valenciana», Cuadernos de Geografia, 72, pp. 289-306.

European Comision and Romania GoVERNMENT REVIEW (2002). «Joint Assesment of Employement Priorities in Romania». Employent and Social Affairs DG, p. 38.

FAINI, R. (2002): Migration, Remittances and Growth, presentado en WIVER, Conference on Poverty, International Migration and Asylum, Helsinky, International Migration Policy Programme.

FAIR, S. y J. DE LuCAS (1999): El desplazamiento en el mundo, Madrid, Secretaría General de Asuntos Sociales, MTAS.

FERNÁNDEZ Cordón, J. A. (1995): Demografia, actividad y dependencia en España, Madrid, Fundación BBV.

Galcoczi, B. (2004): «Proceso de homologación salarial en los países de la ampliación", Boletín Econòmico del ICE, 2.797, pp. 84-85.

GARCíA, J. (1994): «Nación, identidad y paradoja: Una perspectiva relacional para el estudio del nacionalismo», Revista Española de Investigaciones Sociológicas, 67, pp. 165-183.

García Borrego, I. y A. Pedreño (2002): «La inserción de la población extranjera en las áreas agroexportadoras mediterráneas", en DE LuCAS, J. y F. TORRES: Inmigrantes: ¿cómo los tenemos?, Madrid, Talasa.

García CANCLINI, N. (2001): La globalización imaginada, Buenos Aires, Paidós.

GARRIDO, L. y M. REQUENA (1996): La emancipación de los jóvenes en España, Madrid, Instituto de la Juventud.

GELLNER, E. (1983): Nations and Nationalism, Ithaca, Cornell University Press.
-(1998): Nacionalisme, València, Universitat de València-Afers.

GERgEn, K. (1992): El yo saturado, Barcelona, Paidós Ibérica.

GHATAK, S. y P. LEVINe (1993): Migration Theory and Evidence: an Assessment, London, Centre for Economic Policy Research, Discussion paper, 769.

GidDens, A. (1993): Consecuencias de la modernidad, Madrid, Alianza.

- (1995): Modernidad e identidad del yo, Barcelona, Edicions 62.

Godkin, M. A. (1985): «Identidad y lugar: aplicaciones basadas en las nociones de arraigo y desarrollo» en GARCía RAMÓN, M. ${ }^{\text {a }}$ D.: Teoría y método en la Geografía Humana anglosajona, Barcelona, Ariel Geografía, pp. 242-253.

Gómez GIL, C. (2003): La inmigración en Alicante y alguna de sus paradojas, Alacant, Universidad de Alicante.

GonZÁlez ManRique, L. E. (2004): «Inmigración latinoamericana. El caso de Ecuador", Economía Exterior, 28, pp. 141-156.

GozÁlvez Pérez, V. (1990): «El reciente incremento de la población extranjera en España y su incidencia laboral", Investigaciones Geográficas, Alacant, Institut Universitari de Geografía de la Universitat d'Alacant, 8, pp. 7-36. -(1991): "L'immigration des étrangers en Espagne», en EMKe-Poulopoulous I. y otros (1991): International Migration to Northern Mediterranean Countries. The Cases of Greece, Spain and Italy, Pisa, Departamento de Estadística Matemática Aplicada a la Economía, Universidad de Pisa, pp. 47-70. - (1992): «Inmigraciones recientes de extranjeros a España", III as Jornadas de la Población Española. 
-(1993) (dir.): Inmigrantes marroquies y senegaleses en Alicante y Castellón, Universidad de Alicante, Alicante.

- (1995) (dir.): Inmigrantes marroquies y senegaleses en la España mediterránea, Conselleria de Treball i Afers Socials, Generalitat Valenciana, València, 1995. -(1996): «Limmigration étrangère en Espagne (1985-1994)", Revue Européenne des Migrations Internationales, vol. $12,1$.

GuraK, D. y F. CACEs (1998): «Redes migratorias y la formación de sistemas de inmigración", en MalgesinI, G. (comp.): Cruzando fronteras. Migraciones en el sistema mundial, Icaria y Fundación Hogar del Empleado, Barcelona, pp. 75-110.

Hobsbawn, E. J. (2000): Historia del siglo XX: 1914-1990, Barcelona, Ariel.

Hollman, M. y Kallan (2000): Methology and Assuptions for the Population Projections of the United States: 1999 to 2001, us Census Bureau, Population Projections Branco, Population Division, Working Paper n. ${ }^{\circ}$ 38, enero 13, pp. 65-69.

Huntoon, L. (1998): «Immigration to Spain: Implications for a Unified European Union Immigration Policy", International Migration Review, vol. 32, 2, pp. 423-450.

InE: Censo de Población y Viviendas 2001, Instituto Nacional de Estadística, Madrid. http://www.ine.es

- : Padrón de Habitantes, Instituto Nacional de Estadística, Madrid. http:// www.ine.es

Ive: Padrón de Habitantes, explotación especial de la rectificación padronal de 1998 y 2001.

IZQUIERDO, A. (1996): La inmigración inesperada, Madrid, Trotta.
-(2001): «Prioridades de una política europea de inmigración», ponencia al Seminario de Oñate, Instituto Internacional de Sociología Jurídica. IZQUiERdo, A., D. LóPEZ y R. MARTínez (2002): «Los preferidos del siglo XXI: la inmigración latinoamericana en España», Actas del $3^{\text {er }}$ Congreso de la Inmigración en España, vol. 2, Granada, pp. 237-250.

IzQuierdo, A. y R. MARTíneZ (2003): «La inmigración en España en 2001», en Izquierdo, A. (dir.): Inmigración: mercado de trabajo y protección social en Espa$\tilde{n} a$, CES, Colección Estudios, Madrid, pp. 99-181.

Javaloy, F., A. Bechini y J. M. Cornejo (1990): España vista desde Cataluña: estereotipos étnicos en una comunidad plural, Barcelona, PPU.

Kaldor, M. (1999): New and Old Wars. Organized Violence in a Global Era, Stanford University Press.

Kolhberg, L. (1971): «From Is to Ought» en TH. Mishell (comp.): Cognitive Development and Epistemology, New York, pp. 151-236.

KRISTEVA, J. (1991): Estranjeros para nosotros mismos, Madrid, Plaza-Janés.

KRITZ, M. M., L. L. LiM et al. (1992): International migration systems. A global approach, New York, Oxford University Press.

Lanchec, J. Y. (1976): Psycholinguistique et pédagogie des langues, Paris, Presses Universitaries de France.

Leguina, J. (2004): «Inmigración y el nuevo paisaje de las ciudades», Economía Exterior, 28, pp. 77-82.

LiNZ, J. (1985): «From Primordialism to Nationalism» en TIRYAKIAN, E. y RoGowski, R. (eds.): New Nationalisms in 
the Developed West: Toward Explanation. Boston, AllenEUnwin.

Lluch, X. (1999): Plural: educació intercultural 12-16 (ESO), València, Tàndem Edicions.

LoBov, W. (1973): Sociolinguistique, Paris, Les editions de minut.

López MarTínez, M. (ed.) (2004): Enciclopedia de la paz y de los conflictos, 2 volúmenes, Granada, Instituto de la Paz y de los Conflictos, Universidad de Granada.

Luengo, F. (2003): «Mercado de trabajo y competitividad internacional en los países de la ampliación", Boletín Económico del ICE, n. ${ }^{\circ} 2.767$.

MALGESINI, G. (1998): «Introducción», en Malgesini, G. (comp.): Cruzando fronteras. Migraciones en el sistema mundial, Icaria y Fundación Hogar del Empleado, Barcelona, pp. 11-40.

- (1998) (ed.): Cruzando fronteras. Migraciones en el sistema mundial, Barcelona, Icaria.

MARTí, F. (1996): Nacions, estats i fronteres, Vic (Barcelona), Eumo.

MARTín, C. y otros (2002): La ampliación de la Unión Europea. Efectos sobre la economía española, Barcelona, Colección Estudios Económicos, n. ${ }^{\circ}$ 27, Fundación «la Caixa».

Massey, D. S. (1987): «The Ethnosurvey in Theory and Practice", International Migration Review, vol. 21, 4, pp. 1.4981.552.

MASSEY, D. S., J. y otros (1993): «Theories of International Migration: A Review and Appraisal», Population and Development Review, 19, (3), pp. 431-466.

MAULEÓN, I. y J. SARDÀ (1997): «Estimación cuantitativa de la economía sumergida en España», Ekomiaz, 39, pp. 124-135.
Mendoza, C. (2001): «Role of the State in Influencing African Labour Outcomes in Spain and Portugal», Geoforum, San Diego, University California, Working Paper, 3.

Mestre i Mestre, R. (2002): «Dea ex machina. Trabajadoras migrantes y negociación de la igualdad en lo doméstico, Cuadernos de Geografía, 72, pp. 191-206.

Minaescu, C. (2001): Population and Employement: Past, Present, and Future, Bucarest, Editura Economica.

Mingione, E. (1985): «Marginale e povero: Il nuevo inmigrato in Italia», Politica ed Economia, 6, pp. 61-65.

Ministerio de Trabajo y Asuntos SociaLES: Anuario de Migraciones 2002, Dirección General de Ordenación de las Migraciones.

Ministerio Del InTerior: Anuario Estadístico de Extranjería, Delegación del Gobierno para la Extranjería y la Inmigración. Varios años.

Mollà, T. (1990): La llengua dels mitjans de comunicació, Alzira (València), Edicions Bromera.

Morente Megías, F. (ed.) (2000): Cuadernos étnicos. Inmigrantes, claves para el futuro inmediato, Jaén, Universidad de Jaén, Cruz Roja Española.

MuÑoz PÉrez F. y A. IzQuierdo (1989): "L'Espagne pays d'immigration», Population, 2, pp. 257-289.

Muus, P. (2000): Migration, Immigrants and Labour Markets in EU Countries, versión editada de un informe comisionado por National Institute for Working Life, Work and Culture-Norrköping, Sweden, p. 2.

NAPOLEONI, L. (2004): Yihad: cómo se financia el terrorismo en la nueva economía, Barcelona, Urano Tendencias. 
Nedelcu, M. (2003), «E-communautarisme ou l'impact de l'internet sur le quotidien des migrants» en Diminescu, D., (2003) Visvibles mais peu nombreux. Les circulations migratoires roumaines, Paris, Éditions de la Maison des sciences de l'homme.

Ocde (2000): Trends in International Migration, Continuous Reporting System on Migration, Paris, OCDE.

-(2002): Trends in International Migration, Continuous Reporting System on Migration, Paris, OCDE.

-(2002): Economic Assessment-Romania, Juny, Paris, ocDE.

Oit (2004): En busca de un compromiso equitativo para los trabajadores migrantes en la economía globalizada, Informe VI. Conferencia internacional del trabajo, 92 ${ }^{\text {a }}$ reunión. www.ilo.org.

-(2004): Internacional Labour Organization. Internacional labour migration Data Base (ILM). www.ilo.org

Pedreño, A. (2002): «Trabajo y sociedad en los campos de la globalización agroalimentaria», Áreas, 22, Murcia, Universidad de Murcia.

-(2003): «Trabajadores inmigrantes y agricultura intensiva: por qué vinieron a recolectar frutas y hortalizas a los campos del Mediterráneo español y cómo fueron convertidos en fuerza de trabajo vulnerable y disponible", en Tormos, A. (ed.): Los inmigrantes y el mundo del trabajo, Universidad Pontificia Comillas, Madrid, pp. 123145.

Pennec, S. (1996): «La place des familles à quatre générations en France», Population, 1, pp. 31-60.

Pérez Díaz, J. (2003): La madurez de masas, Madrid, Instituto de Migraciones y Servicios Sociales.
Petit, A. (2002): «Una mirada a la comunidad china desde occidente", Cuadernos de Geografía, 72, pp. 321-336.

PinILLOS, J. L. (1960): «Estereotipos raciales de universitarios españoles, ingleses y norteamericanos", Revista de Psicología General y Aplicada, 76, pp. 777-797.

Piore, M. J. (1979): Birds of passage: migrant labour in industrial societies, Cambridge: Cambridge University Press.

Portes, A. y J. Böröcz (1989): «Contemporary Immigration: Theoretical Perspectivas on its Determinants and Modes of Incorporation", Internacional Migration Review, vol. 23, n. ${ }^{\circ}$ 3, pp. 606-630. Versión castellana. PoRTES, A. y J. BÖRÖCZ (1998): «Migración contemporánea. Perspectivas teóricas sobre sus determinantes y sus modalidades de incorporación", en G. MALGESINI (comp.): Cruzando fronteras. Migraciones en el sistema mundial, Barcelona, Icaria, pp. 43-73.

Ротот, S. (2000): «Mobilités en Europe. Étude de deux réseaux migratoires roumains", Sociologie Româneasca, 2, pp. 97-115.

- (2002): «Quand les migrants balkaniques rencontrent ceux venus du Sud", Rencontres. http://www.afebalk.org/ rencontres2002/textes/S.Potot.pdf Programa Greco (2001): editado por el Ministerio de Trabajo y Asuntos Sociales, p. 7.

Pugliesse, E. (1995): «Restructuring of the Labour Market and the Role of the Thirth World Migrations in Europe. Environement and Planning D», Society and Space, 11, pp. 513-522.

Quin, R. y B. McMhon (1997): Historias y estereotipos, Madrid, Ediciones de la Torre. 
Ramírez, S. (1992): Hacia una Psicología Social del Nacionalismo, Madrid, Universidad Complutense.

RAMiro I RocA, E. (1995 a): «Les distàncies personals en un planeta real", BALMA n. ${ }^{\circ}$ 1, Barcelona, Graó, pp. 99115.

- (1995 b): «Camins entre ciutats: alguna cosa més que quilòmetres» en II as Jornadas de Geografia Urbana, Alacant, AGE-Universitat d'Alacant.

-(1995 c): «Coneixement, ús i actituds envers la llengua des de la Geografia de la Percepció» en 1r Congrés de l'Escola Valenciana, València, Federació d'Associacions per la Llengua, pp. 321328.

-(1996 a): «Percepció, Llengua i Secundària post-obligatòria» en Segon Simposi del professorat de valencià de l'ensenyament mitjà i de l'educació secundària obligatòria, València, Servei d'Ensenyaments en Valencià de la Conselleria d'Educació i Ciència, pp. 367-377.

-(1996 b), "Quina imatge es té dels catalans al País Valencià?», Escola Catalana, 332.

- (1997): «Espacio percibido e imágenes territoriales (adolescentes, estudiantes e inmigrantes en el País Valenciano: ¿una realidad neutra?)», en Dinámica Litoral-Interior, vol. II, Santiago de Compostela, Asociación de Geógrafos Españoles-Universidad de Santiago.

-(1998): «Tòpics i estereotips: una clau per a treballar la interculturalitat i els valors", en Actes de la cinquena trobada de sociolingüistes catalans, Barcelona, Departament de Cultura de la Generalitat de Catalunya.

- (2000): «La imagen del País Valenciano: ¿Un turismo tópico y típico?, en
Iber. Didáctica de las Ciencias Sociales, Geografia e Historia, 25, septiembre 2000, pp. 112-119.

-(2003): «Una patera con recursos. (Reflexiones y recursos para tratar el tema de la multiculturalidad), en $L a$ enseñanza de la Geografia ante las nuevas demandas sociales, Toledo, Universidad de Castilla-La Mancha.

- (2004): Tòpics i adolescència: una visió valenciana sobre les diferents autonomies, Servei de Publicacions de la Universitat Jaume I de Castelló.

- (sin publicar): Llengua i Territori (Projecte dinvestigació al voltant de la consciència nacional dels adolescents), Projecte aprovat per la DG de Política Lingüística-Servei d'Investigació i Estudis Sociolingüístics, València.

Ranis y J. C. H. Fei (1961); "A theory of Economic Development", American Economic Review, vol. 51, pp. 533-565.

Relph, E. (1976): Place and Placelessness, Londres, Pion.

Reques, P. y O. DE Cos (2004): «De lo global a lo local: repercusiones geodemográficas de la inmigración en España», Economistas, n. ${ }^{\circ}$ 99, pp. 48-61.

Ribas Mateos, N. (2004): Una invitación a la sociología de las migraciones, Bellaterra, Barcelona.

Rodríguez, M. S., J. M. Sabucedo y C. ARCE (1991): «Estereotipos regionales y nacionales: del conocimiento individual a la sociedad pensante», Revista de Psicología Social, 6-1, pp. 2-22.

Rodríguez SANABRA, F. (1963): «Estereotipos regionales españoles», Revista de Psicología General y Aplicada, 68-69, pp. 763-771.

RogowsKi (eds.): New Nationalism of the Developed West: Toward Explanation, Boston, Allen \& Unwin, pp. 203-253. 
Ros, M., M. Huici y I. CANo (1987): «Languages and Intergroup Relations in Spain", Journal of Langages and Social Psychology, 6, 3-4, pp. 225-243.

-(1990): «Categorización lingüística, identidad social y atribución social", en Musitu G. (ed.) Procesos psicosociales básicos, Barcelona, PPU.

Ruiz de Olabuénaga, J. I. (2000): Inmigrantes, Madrid, Acento Editorial.

Ruiz Miguel, A. (1995): "Las huellas de la igualdad en la Constitución", en Mate, M. R. (ed.): Pensar la igualdad y la diferencia, Madrid, Fundación Argentaria, pp. 109-131.

Salt, J., J. Clarke y S. Schmidt (2000): Patterns and Trends in International Migration in Western Europe, Brussels, Eurostat, European Comission.

SANGRADOR, J. L. (1981): Esterotipos de las nacionatidades y regiones de Espa$\tilde{n} a$, Madrid, Centro de Investigaciones Sociológicas.

-(1990): «Estereotipos sociales: Notas sobre sus rasgos definitorios", en Actas del III ${ }^{e r}$ Congreso Nacional de Psicología Social: Libro de Simposios, Santiago de Compostela, pp. 270-278.

-(1996): Identidades, actitudes y estereotipos en la España de las autonomías, Madrid, Centro de Investigaciones Sociológicas.

SAntos ArnaU, L. (1987): Les Clàusules plurilegislatives dels convenis de la conferència de dret internacional privat de La Haia, Tesis doctoral, Barcelona, UAB.

SAssen, S. (1996), Transnacional Economies and Nacional Immigration Policies, Amsterdam, IMEs, University of Amsterdam.

-(2000): Regulating Inmigration in a Global Age: A new Policy, Lanscape, ANNALS, AAPS.
-(2002): Será este o caminho? Como lidar com a imigraçao na era da globalizaçao, Revista Crítica de Ciencias Sociais, 64, Coimbra.

SEARles, H. F. (1960): The Nonhuman Environment, Nueva York, Internacional University Press.

Sempere, J. D. (2002): «Marroquíes y ecuatorianos en la agricultura intensiva del litoral mediterráneo", Cuadernos de Geografia, 72, pp. 173-190.

SimON, G. (2002): Les migrations internationals, PopulationESociétes, n. ${ }^{\circ} 383$, INED, Paris.

SJAASTAD, L. A. (1962): «The Costs and Returns of Human Migration", Journal of Political Economy, vol. 70, 5, part 2, pp. 80-93.

Sneddon Little, J. y R. K. TRiest (2002): «The Impact of Demographic Change on us Labor Markets», New England Economic Review, primer trimestre 2002, editado por Federal Reserve Bank de Boston, pp. 49-72.

Sopemi (2001): Tendances des migrations internationales. Rapport Annuel 2001, Paris, OCDE.

Sopemi (2003): Tendances des migrations internacionales, Organisation de Coopération et Développement Économiques, Paris.

Stanculescu, M. S. y I. Berevoescu (2003): "HWs (Household, Work and Flexibility)", Critical Review of Literature, editado por HWF Consortium y coordinado por Claire Wallace del Instituto de Estudios Avanzados de Viena, pp. 189-225.

StANVENHAgen, R. (1996): «La educación para un mundo multicultural», en DELORS, J. (1996): La educación encierra un tesoro (Informe a la UNESCO de la Comisión Internacional sobre la educa- 
ción para el siglo XXI), Madrid, Santillana-Ediciones.

STARK, O. (1984): «Migration Decision Making: a Review Article». Journal of Development Economics, 14, pp. 251-259.

-(2003): Rethinking the Brain Drain, Bonn, zEF (Zentrum für Entwicklungs forschung).

STOLCKE (1998): «Entropy-based Pruning of Backoff Language Models» in Proc. DRAPA News Transcriptionand Understanding Workshop, Lansdowne, vA, pp. 270-274.

SwERDLOW, J. L. (1999): «Cultura global», National Geographic, agosto 1999, V, n. ${ }^{\circ} 2$, Barcelona, RBA Publicacions.

TAYlor, Ch. (2000): «Las fuentes de la identidad moderna», Debats, 68, pp. 30-45.

TEJERINo, B. (1999): «El poder de los símbolos. Identidad colectiva y movimiento etnolingüístico en el País VasCo", Reis, 88, pp. 75-105.

The World Bank, (2002): The First Ten Years. Analysis and Lessons for Eastern Europe and The Former Soviet Union, Washington, DC.

Thompson, R. y J. R. Rudolph (1992): Politica etnoterritorial, Barcelona, Pomares-Corredor.

TODARO, M. (1976): Internal Migration in Developing Countries, Genève, International Labour Office.

TORRES, F. (2002 a): «Els immigrants a la ciutat de València: la inserció urbana dels nous veïns", Cuadernos de Geografia, 72, pp. 259-288.

- (2002 b): «Inserción laboral e inserción social de los inmigrantes en las áreas agroexportadoras mediterráneas. La importancia de los contextos locales», Áreas, n. ${ }^{\circ}$ 22, Murcia, Universidad de Murcia.
TuAn, Y. F. (1971): «Geography, Phenomenology and the Study of Human Nature», The Canadian Geographer, 15, pp. 181-182.

Ugarte, J. L. (2004): «España, país de inmigración», Economía Exterior, 28, pp. 15-26.

VAsile, V. (2004): Demographic Changes and Labour Market in Romania, Institute of National Economy, Romanian Academy, PIE Discussion Paper.

Villán, I. (2002): «El Padrón continuo como instrumento para el conocimiento de la inmigración en España", Fuentes Estadísticas, 69. http://www. fuentesestadisticas.com/

Viruela Martínez, R. (1993): “Condiciones de vida y de trabajo de los magrebíes en España: marroquíes en la provincia de Castelló", Inmigración extranjera y planificación demográfica en España, Universidad de la Laguna, pp. 547-556.

-(2002): «La nueva corriente inmigratoria de Europa del Este», Cuadernos de Geografia, 72, pp. 231-258.

-(2003): «Transición y migraciones en Europa central y oriental», Migraciones, 14: 181-218.

-(2004): «El recurso de la emigración. Balance durante la transición en Rumanía», Papeles del Este, 9. http:// www.ucm.es/Bucm/cee/papeles/09/ pape0404220011a.pdf.

-(2004): «La emigración de la Europa poscomunista: su incidencia en el País Valencià», Saitabi (en prensa).

Viruela, R. y C. Domingo (2001): «Población extranjera en el País Valenciano: entre el turismo residente y la inmigración laboral», Arxius de Ciències Socials, n. ${ }^{\circ} 5$ (monográfico: «Inmigració i Societat»), pp. 147-182. 
VV.AA. (2004): Movimientos de población, Barcelona, Icaria.

WENKART, A. (1961): «Regaining Identity Trough Relatedness", American Journal of Psychoanalysis, 21, pp. 227-233.

ZAmFIR, C. (2003): «Poverty and social exclusion in Romania». Worldbank data, p. 14

Zlotnik, H. (1991): Migration. The Demographic Aspects, Paris, OCDE.

ZWINGLE, E. (1999): «Un mundo unido», National Geographic, agosto 1999, V, 2. 


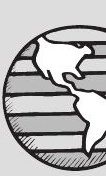

Índice de cuadros, gráficos y figuras 


\section{Movimientos de población en la sociedad global}

Cuadro 3.1. Distribución de los trabajadores migrantes en el año 2000 por continentes

Cuadro 3.2. Distribución de los refugiados en el año 2002 por continentes .. $\quad 72$

Cuadro 3.3. Evolución del número de refugiados en el mundo, 1980-2002 .. 72

Cuadro 3.4. Distribución de los desplazados en el mundo por países .......... 73

\section{Aproximación teórica a los conceptos de identidad y estereotipos en una sociedad intercultural}

Figura 4.1. Cartel de Manos Unidas

Cuadro 4.1. Ejemplificación de la dinámica de los estereotipos:

el caso de los indígenas

\section{La immigració actual a Espanya. Aspectes demogràfics}

Gràfic 5.1. Evolució dels permisos de residència, Espanya, 1991-2003

Gràfic 5.2. Comparació entre les dades dels Permisos de residència a 31 de desembre de 2001, el Cens de població i habitatge a novembre de 2001 i el Padró continu a 1 de gener de 2002

Gràfic 5.3. Fluxos internacionals arribats a Espanya per grans agrupacions continentals, 1991-2002

Gràfic 5.4. Permisos de residència a Espanya, 1991-2003.

Percentatges per agrupacions continentals

Gràfic 5.5. Distribució percentual dels estrangers segons les 15 primeres nacionalitats a Espanya, segons dades del Padró continu a 2003

Figura 5.1. Piràmide de població del total d'estrangers i de diferents nacionalitats per estat civil. España, 2001

Figura 5.2. Distribució de les persones de nacionalitat estrangera en el territori espanyol 
Figura 5.3. Pes de la població estrangera sobre el total de la població de les províncies espanyoles

Figura 5.4. Distribució territorial de les principals nacionalitats estrangeres Gràfic 5.6. Comparació dels nivells d'instrucció dels espanyols censats al 2001, per sexe i grups d'edat

\section{Algunas consideraciones sobre los procesos migratorios en España y en tierras valencianas}

Cuadro 6.1. Población extranjera en 18 países europeos, en miles de personas y porcentajes, 1996

Cuadro 6.2. Evolución de la población extranjera residente en España y en el País Valenciano

Cuadro 6.3. Afiliación de extranjeros comunitarios a la Seguridad Social en el País Valenciano por porcentajes respecto al total de extranjeros afiliados, 2002

Cuadro 6.4. Residentes extranjeros en España por Comunidades Autónomas, 2001

Cuadro 6.5. Residentes extranjeros en las comarcas valencianas, 2001

Cuadro 6.6. Residentes extranjeros en el País Valenciano, por países de procedencia. Principales contingentes, 2001

Cuadro 6.7. Extranjeros empadronados en el País Valenciano por provincias (01-01-02) y porcentajes respecto a la población total y al total de población inmigrada

Cuadro 6.8. Porcentaje de inmigrantes por provincias según procedencia (entre paréntesis cifras absolutas), 2001

Cuadro 6.9. Inmigrantes por origen en la provincia de Castellón

Cuadro 6.10. Concentración mayoritaria de la población inmigrante en la provincia de Castellón

Cuadro 6.11. Distribución sectorial de los trabajadores inmigrantes en la UE, 2000

Cuadro 6.12. Trabajadores extranjeros

Figura 6.1. Evolución anual de los permisos de trabajo concedidos y del número de trabajadores extranjeros con permiso de trabajo en el País Valenciano

\section{Extranjeros en el País Valencià} (una aproximación imperfecta a la inmigración)

Figura 7.1. Extranjeros residentes en el País Valencià

Cuadro 7.1. Principales países de procedencia de la población extranjera en 2003 en el País Valencià 
Figura 7.2. Variación absoluta de los extranjeros empadronados entre 1998 y 2003

Figura 7.3. Proporción de extranjeros sobre la población total en 2003 ........ $\quad$ I55

Figura 7.4. Variación absoluta de los extranjeros empadronados entre 1998 у 2003 ....................................................................... $\quad$ I56

Figura 7.5. Proporción de extranjeros sobre la población total en 2003 ....... $\quad$ I56

Cuadro 7.2. Extranjeros residentes en el País Valencià, en 1998, 2001 y 2003.. $\quad$ I58

Cuadro 7.3. Trabajadores extranjeros de alta en la Seguridad Social por regiones de procedencia ............................................................... I6I

Cuadro 7.4. Trabajadores extranjeros por provincia y regímenes de cotización en enero de 2003 I62

Figura 7.6. Trabajadores extranjeros afiliados en los regímenes especiales de la Seguridad Social (en abril de 2003). Provincias de Castelló y València ...

\section{Iguals però menys: la colònia romanesa a Castelló}

Quadre 8.1. La distribució percentual dels al·lòctons respecte a la població total provincial, 2003

Quadre 8.2. La distribució de la irregularitat segons l'origen. Castelló 2002 .. $\quad$ I82

Gràfic 8.1. Evolució de la població de la província de Castelló, diferenciant entre autòctons i alllòctons, 1991-2005. Base 100 en 1991

Quadre 8.3. Variacions del nombre d'al·lòctons residents a la província de Castelló i taxes de creixement anual acumulatiu

Gràfic 8.2. Evolució de la distribució percentual de les colònies més representatives d'al·lòctons a la província de Castelló, 1991-2005

Quadre 8.4. Taxes de creixement anual acumulatiu de les colònies d'al·lòctons més nombroses a la província de Castelló

Gràfic 8.3. Distribució dels percentatges d'al·lòctons dels municipis de Castelló a 1 de gener de 2004 segons el nombre d'habitants

Quadre 8.5. Distribució comarcal de la població de la província de Castelló a 1 de gener de 2004

Quadre 8.6. Distribució percentual dels al-lòctons als municipis on un origen era majoritari i que en total tenien aveïnats més de 100 nouvinguts. Dades d'1 de gener de 2004

Quadre 8.7. Distribució percentual dels al·lòctons als municipis on dues de les àrees d'origen eren majoritàries i que en total tenien aveïnats més de 100 nouvinguts. Dades d'1 de gener de 2004

Quadre 8.8. Distribució percentual dels al·lòctons als municipis on dues de les àrees d'origen no eren majoritàries i que en total tenien aveïnats més de 100 nouvinguts. Dades d'1 de gener de 2004

Gràfic 8.4. Evolució anual de la relació de masculinitat d'algunes comunitats d'al·lòctons a la província de Castelló, 1996-2005 
Quadre 8.9. Distribució per grans grups d'edats de diferents col·lectius de la població de la província de Castelló en 2004

Gràfic 8.5. Estructura per edat i sexe de la població autòctona de la província de Castelló a 1 de gener de 2004 I98

Gràfic 8.6. Estructura per edat i sexe de la població al·lòctona de la província de Castelló a 1 de gener de 2004 198

Gràfic 8.7. Distribució per grups d'edat quinquennals dels romanesos i dels autòctons de la província de Castelló a 1 de gener de 2004

Gràfic 8.8. Distribució percentual de la població autòctona i al·lòctona de la província de Castelló en 2001 segons els seus nivells d'estudis

Quadre 8.10. Distribució per sexe, grup d'edat i estat civil dels alllòctons i dels romanesos a 1 de novembre de 2001. Xifres absolutes y percentuals .. 204

Gràfic 8.9. Distribució percentual dels habitants de la província de Castelló en 2001, segons el nombre de persones per llar i diferenciant entre autòctons i al·lòctons 206

Quadre 8.11. Distribució percentual dels habitants de la província de Castelló en 2001, segons el model corresidencial i diferenciant entre autòctons i al'lòctons

Gràfic 8.10. Evolució de la taxa d'ocupació d'Espanya i les tres províncies valencianes, 1977-2004

Quadre 8.12. Evolució de la taxa de fertilitat de Romania (naixements vius per 1.000 dones en edat fèrtil) entre 1966 i 1994

Gràfic 8.11. Canvis percentuals en la distribució de l'ocupació en els sectors públic i privat de Romania, 1994 i 2001 


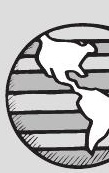

Relación de autores 
Khamlichi Abourbakr. Coordinadora de Asociaciones del Norte de Marruecos.

ANDReu Domingo i ValLs. Centre d'Estudis Demogràfics.

Concha Domingo Pérez. Departament de Geografia, Universitat de València.

JaVIER DE LuCAS. Departament de Filosofia del Dret, Universitat de València.

Rafael Viruela Martínez. Departament de Geografia, Universitat de València.

MerCedes AlcañIz. Departament de Filosofia, Sociologia i Comunicació Audiovisual i Publicitat, Universitat Jaume I.

Joan Serafí Bernat i Martí. Departament d'Economia, Instituto de Desarrollo Local, Universitat Jaume I.

Celestí Gimeno i Broch. Departament d'Economia, Instituto de Desarrollo Local, Universitat Jaume I.

Andrés Piqueras. Departament de Filosofia, Sociologia i Comunicació Audiovisual i Publicitat, Universitat Jaume I.

EnRic Ramiro Roca. Departament d'Educació, Universitat Jaume I. 


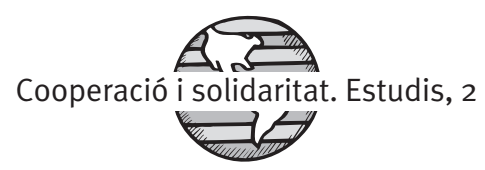




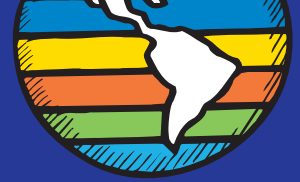

\section{Cooperació i solidaritat. Estudis, 2}

La potencia que han alcanzado en los últimos años los flujos hacia una parte importante del Estado español, unido a la ausencia de cualquier tipo de política de inmigración y a la negativa imagen que han reiterado algunos medios de comunicación y miembros de la clase política, ha disparado el interés del tema migratorio y ha llegado a preocupar a la opinión pública. Un fenómeno tan positivo, enriquecedor y clave para el futuro de nuestra comunidad es visualizado desde su perspectiva más negativa.

Conocer la nueva realidad emergente mediante la realización de estudios científicos y aprender de las experiencias de otros países con mayor tradición de acogida, son elementos fundamentales para encauzar los pasos que ya se están produciendo hacia una sociedad multicultural. Difundir los resultados de los trabajos de los investigadores es una buena manera de sensibilizar a la población autócotona, única forma de avanzar hacia una sociedad más inclusiva. Con esta publicación, y otras muchas iniciativas, la UJI pretende fomentar los valores de la solidaridad, la diversidad, la interculturalidad y el diálogo entre las personas y las naciones.

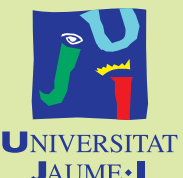

